\title{
НАУКА
}

\section{I ПРАВООХОРОНА №2(44), 2019}

\section{Засновано 2007 року}

Видається 4 рази на рік (лист Міністерства юстиції України

від 02.06.2009

№ 7446-0-33-09-32)

\section{Відповідно до наказу МОН України}

від 26.05.2014 № 642 журнал "Наука і правоохорона” включено до Переліку наукових фахових видань України відповідно до списку згідно з додатком 9 (юридичні науки)

\section{Зареєстровано \\ Міністерством юстищії України}

Свідоцтво про державну реєстрацію друкованого засобу масової інформації: серія КВ № 13082-1966Р від 21.08.2007

Науковий журнал "Наука i правоохорона” внесено до переліку міжнародної наукометричної бази Index Copernicus International Journals Master List

\section{Рекомендовано до друку}

Вченою радою Державного науково-дослідного інституту МВС України

(протокол від 19.06.2019 № 4)

\section{Aдpeca}

01011, м. Київ, пров. Свгена Гуцала, 4-а Телефон: (044) 254-95-21 Факс: (044) 280-01-84 E-mail: dndi@mvs.gov.ua http:// naukaipravoohorona.com/
РЕДАКЦІЙНА КОЛЕГІЯ

Головний редактор

КРИВОЛАПЧУК В.О., д.ю.н., проф. (ДНДІ)

Заступник головного редактора

МУЗИКА А.А., д.ю.Н., проф. (ДНДІ)

Відповідальний секретар

ПЛУГАТАР Т.А., К.ю.н., с.н.с. (ДНДІ)

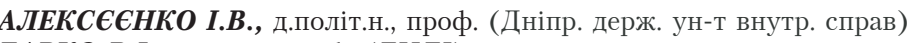

БАРКО В.I., д.псх.Н., проф. (ДНДІ)

БЕРЛАЧ Н.A., д.Ю.Н., проф. (ДНДІ)

БІЛОУС В.T., д.ю.н., проф. (ДНДІ)

БОНДАРЕНКО В.Д., д.філос.н., проф. (ДНДІ)

БУХАНЕВИЧ О.М., Д.Ю.Н., доцент (ХУУП)

ВЕРБЕНСЬКИЙ М.Г., Д.Ю.Н., проф. (ДНДІ)

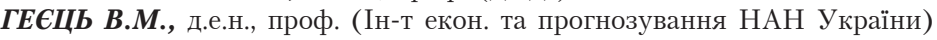
дОЛжЕНКОВ О.Ф., д.ю.н., проф. (Південноукр. нац. пед. ун-т ім. К.Д. Ушинського)

ЗАРОСИЛО В.О., д.ю.н., проф. (МАУП)

КОПИЛЕНКО О.Л., д.ю.н., проф. (Ін-т законодавства Верховної Ради

України)

КОПОтУН I.м., д.ю.н., проф. (Academy HUSPOL, Czech Republik;

EIDV, Slovakia)

КОРИСТІН О.є., д.ю.Н., проф. (ДНДІ)

кУЛИк о.Г., д.ю.н., с.н.с. (ДНДІ)

МАРТИНЕНКО О.А., д.ю.Н., проф. (ДНДІ)

МИСЛИВИЙ В.A., д.Ю.Н., проф. (ДНДІ)

MILAN HEJDIS, Paed. Dr., Ph.D. (Academy HUSPOL, Czech Republik)

НАВРОЦЬКИЙ В.О., д.ю.н., проф. (Львів. держ. ун-т внутр. справ)

ПОПОВИЧ В.М., д.ю.н., проф. (ДНДІ)

ПРОЦЕНКО Т.О., д.ю.Н., проф. (ДНДІ)

РЯДІНСЬКА В.О., д.ю.Н., проф. (ДНДІ)

СВИРИДЮК Н.П., д.ю.Н., доцент (ДНДІ)

ФЕДОТОВА $\boldsymbol{\Gamma . \boldsymbol { B } . , ~ д . ю . Н . , ~ с . н . с . ~ ( Д Н Д І ) ~}$

ШІПІНА І.М., д.ю.Н., проф. (Військовий інститут КНУ ім. Тараса

Шевченка)

БРІСДЕ ЯУТPITE, д.Ю.Н., проф. (Латвійський ун-т, Латвійська

Республіка)

ЯРМИШ О.Н., д.ю.н., проф. (Ін-т законодавства Верховної Ради

України)

ОПРИШКО І.в., к.ю.н., с.н.с., доцент (ДНДІ)

\section{Засновник і видавець}

(C) Державний науково-дослідний інститут МВС України

Науковий журнал посів I місце в конкурсі на краще наукове періодичне видання в системі МВС України у 2010 році, II місце у 2011 і 2012 роках та III місце у 2014 році.

За точність викладеного матеріалу відповідальність несуть автори статей та їх рецензенти.

Київ 2019 


\section{NAUKA}

\section{PRAVOOKHORONA}

№ 2(44), 2019

\section{Founded in 2007}

Issued four times a year (Letter of the

Ministry of Justice of Ukraine dated 02.06 .2009

No. 7446-0-33-09-32)

\section{By order}

No 642, dated 26.05.2014 included into the Ministry of Education and Science of Ukraine's law sciences special edition list according to annex 9 (legal sciences)

\section{Registered}

by Ministry of Justice of Ukraine

State registration certificate series $\mathrm{KV}$

No. 13082-1966R dated 21.08.2007

Scientific journal "Nauka i Pravookhorona" included in the list of international database

Index Copernicus International Journals Master List

\section{Recommended}

by State Research Institute's Scientific Council (Record No. 4 dated 19.06.2019)

\section{Adress}

4a Ye.Gutsalo Lane, UA01011 Kyiv, Ukraine tel.: +380442549521 fax: +380442800184 E-mail: dndi@mvs.gov.ua http:// naukaipravoohorona.com/ \begin{tabular}{|l} 
E \\
E \\
KR \\
$\mathrm{M}$ \\
D \\
$\mathbf{M}$ \\
$\mathrm{U}$ \\
E \\
$\mathbf{P}$ \\
$\mathrm{I}$ \\
$\mathrm{A}$ \\
$\mathrm{S}$ \\
$\mathbf{B}$ \\
$\mathrm{M}$ \\
$\mathrm{B}$ \\
$\mathrm{U}$ \\
$\mathrm{B}$ \\
$\mathrm{B}$ \\
$\mathrm{U}$ \\
$\mathrm{B}$ \\
$\mathrm{B}$ \\
$\mathrm{M}$ \\
$\mathrm{V}$ \\
$\mathrm{M}$
\end{tabular} TORIAL BOARD

Editor-in-Chief

KRYVOLAPCHUK V.O., Doctor of Juridical Sciences, Full Professor (State Research Institute MIA Ukraine)

Deputy Editor-in-Chief

MUZYKA A.A., Doctor of Juridical Sciences, Full Professor (State Research Institute MIA Ukraine)

Executive Secretary

PLUHATAR T.A., Candidate of Juridical Sciences, Senior Research Associate (State Research Institute MIA Ukraine)

ALEKSIEIENKO I.V., Doctor of Political Sciences, Full Professor (Dnipropetrovsk State University of Internal Affairs)

BARKO V.I., Doctor of Psychological Sciences, Full Professor (State Research Institute MIA Ukraine)

BERLACH N.A., Doctor of Juridical Sciences, Full Professor (State Research Institute MIA Ukraine)

BILOUS V.T., Doctor of Juridical Sciences, Full Professor (State Research Institute MIA Ukraine)

BONDARENKO V.D., Doctor of Philosophical Sciences (State Research Institute MIA Ukraine) BUKHANEVYCH O.M., Doctor of Juridical Sciences, Docent (Khmelytsky University of Management and Law)

VERBENSKYI M.H., Doctor of Juridical Sciences, Full Professor (State Research Institute MIA Ukraine)

HEIETS V.M., Doctor of Economic Sciences, Full Professor (Institute of Economics and Forecasting of NAS of Ukraine)

DOLZHENKOV O.F., Doctor of Juridical Sciences, Full Professor (South Ukrainian K.D. Ushynky NPU)

ZAROSYLO V.O., Doctor of Juridical Sciences, Full Professor (IAPM)

KOPYLENKO O.L., Doctor of Juridical Sciences, Full Professor (Legislation Institute of the Verkhovna Rada of Ukraine)

KOPOTUN I.M., Doctor of Juridical Sciences, Full Professor (Academy HUSPOL, Czech Republik; EIDV, Slovakia)

KORYSTIN O.Ye., Doctor of Juridical Sciences, Full Professor (State Research Institute MIA Ukraine)

KULYK O.H., Doctor of Juridical Sciences, Senior Research Associate (State Research Institute MA Ukraine)

MARTYNENKO O.A., Doctor of Juridical Sciences, Full Professor (State Research

Institute MA Ukraine)

MYSLYVYI V.A., Doctor of Juridical Sciences, Full Professor (State Research Institute MIA Ukraine)

MILAN HEJDIS, P.Dr., Ph.D. (Academy HUSPOL, Czech Republic)

NAVROTSKYI V.O., Doctor of Juridical Sciences, Full Professor (Lviv State University of Internal Affairs)

POPOVYCH V.M., Doctor of Juridical Sciences, Full Professor (State Research Institute MIA Ukraine)

PROTSENKO T.O., Doctor of Juridical Sciences, Full Professor (State Research Institute

MIA Ukraine)

RIADINSKA V.O., Doctor of Juridical Sciences, Full Professor (State Research Institute

MIA Ukraine)

SVYRYDIUK N.P., Doctor of Juridical Sciences, Docent (State Research Institute MIA Ukraine)

FEDOTOVA H.V., Doctor of Juridical Sciences, Senior Research Associate (State Research Institute MIA Ukraine)

SHOPINA I.M., Doctor of Juridical Sciences, Full Professor (Military Institute

of Taras Shevchenko National University of Kyiv)

BRIEDE JAUTRITE, Doctor of Juridical Sciences, Full Professor (University of Latvia, Latvian Republic)

YARMYSH O.N., Doctor of Juridical Sciences, Full Professor (Legislation Institute of the Verkhovna Rada of Ukraine)

OPRYSHKO I.V., Candidate of Juridical Sciences, Senior Research Associate (State

Research Institute MIA Ukraine)

Founder

(C) State Research Institute MIA Ukraine

The scientific journal won 1st place in the competition for the best scientific periodical in the system of the Ministry of Internal Affairs of Ukraine in 2010, the second place in 2011 and 2012, the third place in 2014

For the accuracy of the posted material, the authors and reviewers are responsible. 
DOI (Issue): https://doi.org/10.36486/np.2019.2

\section{M I C T}

\section{ТЕОРІЯ ТА ФІЛОСОФІЯ ПРАВА. ПОРІВНЯЛЬНЕ ПРАВОЗНАВСТВО. ІСТОРІЯ ПРАВА ТА ДЕРЖАВИ}

Бондаренко В.Д. Свобода совісті як об'єкт правового регулювання в сучасній Україні

Чисников В.Н. Нормативно-правовое регулирование внутреннего (агентурного) наблюдения в органах политического сыска Российской империи начала XX в.: некоторые дискуссионные вопросы современной историографии

Греченко В.А., Ярмиш О.Н. Організація і діяльність міліції Української РСР у 1951 р.

\section{КОНСТИТУЦЙНЕ ПРАВО. МУНІЦИПАЛЬНЕ ПРАВО}

Вербенський М.Г. Забезпечення свободи волевиявлення громадян під час виборів Президента України 2019 року: правовий аспект

\section{АДМІНІСТРАТИВНЕ ПРАВО І ПРОЦЕС. ФІНАНСОВЕ ПРАВО}

Берлач Н.А. Про особливості державної політики з відновлення державного суверенітету України в Донецькій та Луганській областях

Білоус В.Т., Стасюк О.Л. Адміністративно-правові гарантії реалізації правозахисної функції в Україні

Kryvolapchuk V.O. Preventive Activities of the National Police of Ukraine in the Current Legal Sphere

Protsenko T.O. Forming and Implementation of Gender Equality Policy in the System of the Ministry of Internal Affairs of Ukraine

Рядінська В.О., Коллер Ю.С., Діхтяренко К.Ю. Поняття монетарних металів та їх співвідношення із категорією "банківські метали"

Солдатенко О.В. Відновлення державного суверенітету в окремих районах України: політичні підходи та наукове обгрунтування

Циганов О.Г. Види поліцейських послуг в Україні та організаційно-правове забезпечення їх надання

\section{КРИМІНАЛЬНЕ ПРАВО ТА КРИМІНОЛОГІЯ. КРИМІНАЛЬНО-ВИКОНАВЧЕ ПРРАВО}

Дрозд В.Г. Недопустимість розголошення відомостей досудового розслідування як умова досягнення завдань кримінального провадження

Заросило В.О. Організована злочинність у сучасному світі та в Україні: форми, види та зміни

Користін О.Є., Собко Г.М. Методологічні засади осмислення феномену “насильство” у кримінальному праві

Кулик О.Г. Кримінальна ситуація в Україні: сучасні тенденції

Мартиненко О.А. Робота поліції в умовах деокупації: зарубіжний досвід та криміногенні виклики 
DOI (Issue): https://doi.org/10.36486/np.2019.2

Мисливий В.А. Злочини проти безпеки дорожнього руху і крайня необхідність

Музика А.А. Спеціальна конфіскація за Кримінальним кодексом України: науково-практичний коментар

Попович В.М. Методологія термінологічно-понятійного відображення криміногенних процесів у сфері економіки

Svyrydiuk N.P. Rationale of the Concept of Anti-Criminal Intelligence of Law Enforcement Agencies in Ukraine

Федотова Г.В., Лісниченко Л.В. Стан науково-теоретичної розробленості проблем запобігання грабежам та розбійним нападам

\section{ЮРИДИЧНА ПСИХОЛОГІЯ ТА ПЕДАГОГІКА. ПСИХОЛОГІЧНЕ ЗАБЕЗПЕЧЕННЯ ПРАВООХОРОННОЇ ДІЯЛЬНОСТІ}

Барко В.І., Барко В.В., Кирієнко Л.А. Розроблення україномовного опитувальника толерантності до невизначеності для використання в Національній поліції України

\section{РЕЦЕНЗІї}

Бортник Н.П. Тенденції вдосконалення термінологічного апарату адміністративно-процесуальної теорії (рецензія на монографію Тернущака М.М. "Правова природа адміністративного процесу в контексті публічного адміністрування”) 


\section{CONTENS}

\section{THEORY AND PHILOSOPHY OF LAW. COMPARATIVE LAW. HISTORY OF LAW AND STATE}

Bondarenko Viktor. Freedom of Conscience as an Object of Legal Regulation in Modern Ukraine

Chysnikov Volodumyr. Normative and Legal Regulation of Internal (Agenturial) Surveillance in the Bodies of Political Search of the Russian Empire at the Beginning of the 20th Century: Some Discussion Issues of Modern Historiography

Hrechenko Volodymyr, Yarmysh Oleksandr. Organization and Activities of the Ukrainian SSR Militia in 1951

\section{CONSTITUTIONAL LAW. MUNICIPAL LAW}

Verbenskyi Mykhailo. Ensuring the Freedom of Expression of the Will of Citizens during the Presidental Elections in Ukraine 2019: The Legal Aspect

\section{ADMINISTRATIVE LAW AND PROCESS. FINANCIAL LAW}

Berlach Nataliia. Pecularities of State Policy on Restiration State Sovereignty of Ukraine in Donetsk and Lunansk Regions

Bilous Viktor, Stasiuk Oksana. Administrative and Legal Guarantees for the Implementation of the Human Rights Function in Ukraine

Kryvolapchuk Volodymyr. Preventive Activities of the National Police of Ukraine in the Current Legal Sphere

Protsenko Taras. Forming and Implementation of Gender Equality Policy in the System of the Ministry of Internal Affairs of Ukraine

Riadinska Valeriia, Koller Yurii, Dikhtiarenko Kyrylo. The Concept of Monetary Metals and Their Ratio with the Category of "Bank Metals"

Soldatenko Oksana. Restoration of State Sovereignty in Selected Areas of Ukraine: Policy Approaches and Scientific Rationale

Tsyhanov Oleh. Types of Police Service in Ukraine and Organizational-Legal Sypply of Their Provision

\section{CRIMINAL LAW AND CRIMINILOGY. CRIMINAL AND EXECUTIVE LAW}

Drozd Valentyna. Inadmissibility of Disclosing Information of Pre-Tial Investigation as a Precondition for Achieving Criminal Proceedings Objectives

Zarosylo Volodymyr. Ordanized Crime in the Modern World and Ukraine: Forms, Types and Changes

Korystin Oleksandr, Sobko Hanna. Methodological Basis for Understanding the Phenomenon of "Violence" in Criminal Law 
DOI (Issue): https://doi.org/10.36486/np.2019.2

Martynenko Oleh. Police Work under Conditions of Deocupation: Foreign Expeience and Criminogenic Challenges

Myslyvyi Volodymyr. Road Safety Crimes and Extreme Necessity

Muzyka Anatolii. Special confiscation under the Criminal Code of Ukraine: Scientific and Practical Commentary

Popovych Volodymyr. Methodology of Terminological and Conceptual Reflection of Criminogenic Processes in the Sphere of Economy

Svyrydiuk Nataliia. Rationale of the Concept of Anti-Criminal Intelligence of Law Enforcement Agencies in Ukraine

Fedotova Hanna, Lisnychenko Liliia. State of Scientific and Theoretical Development of Problems with Prevention of Plundering and Robberies

\section{LEGAL PSYCHOLOGY AND PEDAGOGY. PSICHOLOGICAL LAW ENFORCEMENT SUPPORT}

Barko Vadym I., Barko Vadym V., Kyriienko Liudmyla. Development of a UkrainianSpeaking Questionnaire on Tolerance to Uncertainty for use by the National Police of Ukraine

\section{REVIEWS}

Bortnyk Nadiia. Trends of improving the terminological apparatus of administrative and procedural theory (Review of the monograph by Ternuschak M.M. on the topic: "Legal nature of the administrative process in the context of public administration") 
DOI (Issue): https://doi.org/10.36486/np.2019.2

Issue 2(44) 2019

\title{
ТЕОРІЯ ТА ФІЛОСОФІЯ ПРАВА. ПОРІВНЯЛЬНЕ ПРАВОЗНАВСТВО. ІСТОРІЯ ПРАВА ТА ДЕРЖАВИ
}

УДК 322

\author{
Бондаренко Віктор Дмитрович, \\ доктор філософських наук, професор, \\ головний науковий співробітник \\ ДНДI МВС України, м. Київ, Україна \\ ORCID ID 0000-0003-4251-3448
}

\section{СВОБОДА СОВІСТІ ЯК ОБ'ЄКТ ПРАВОВОГО РЕГУЛЮВАННЯ В СУЧАСНІЙ УКРАЇНІ}

У статті обгрунтовується думка про те, що попри функціонування в Украйні конституційного принщипу про відокремлення Церкви від держави, а школи від Церкви, інші правові механізми залишаються визначальним важелем, що забезпечує подальший розвиток релігійного середовища, утвердження свободи совісті та продуктивних державно-церковних відносин.

Автор піддає аналізу усі ключові законодавчі та нормативно-правові акти, що забезпечили становлення і розвиток свободи совісті в Україні у роки ї̈ незалежності. Особлива увага приділяється законодавчим актам, що побачили світ в останні п'ять років у зв'язку з співіснуванням в Україні двох канонічних православних юрисдикщій - Православної Церкви України та Української Православної Церкви.

Ключові слова: принщи свободи совісті, украӥнське законодавство про свободу совісті, забезпечення природних прав людини, Україна як світсъка держава, законодавче забезпечення єдності православних в Україні, суб'єктність українських церков, автокефалія православних як атрибутивна ознака православних держав.

Свобода совісті як одне з фундаментальних прав і свобод людини, що відноситься до розряду ії̈, так званих природних, прав, сягає своїми витоками декалогу як правової норми, що декларує необхідність установлення і збереження нерозривного зв’язку з Богом. У такому або дещо видозміненому вигляді ця біблійна норма, що перейшла у сферу законодавчого регулювання життя людини, суспільства і держави, існує аж до епохи зародження капіталізму. Останній за своєю сутністю потребував, з одного боку, розширення сфери людських свобод, а з другого - прагнув розриву основи феодального ладу, що полягала у союзі середньовічної церкви і феодальної верхівки. Тому вже перші буржуазні революції у своїх правових трактовках розвитку суспільства і людини наголошували на свободі вибору релігії (а згодом і у відмові від будь-якої релігії), відокремленні Церкви від держави, а школи від Церкви.

Варіативність використання цієї норми залежала від практики правозастосування, що складалася у кожній країні по-різному. В українських землях діяли норми тих держав, до яких ці землі тоді належали. Цим, зокрема, пояснюється

DOI (Article): https://doi.org/10.36486/np.2019.2.01

(c) Bondarenko Viktor, 2019 
неприродна, з першого погляду, різниця у різній конфесійній конфігурації в сусідніх областях сучасної України. Причину цієї різниці слід шукати саме у різній формі реалізації законів, що регулювали релігійно-церковне життя. Найкращим цьому прикладом є різний ступінь присутності іудаїзму та його пам'ятних місць (лінія осілості євреїв), протестантів, католиків, греко-католиків, православних та мусульман, що будували своє життя відповідно до преференцій чи перешкод, які створювалися для них різними державами згідно з їхнім законодавством. Котрась із держав фаворизувала ту чи іншу релігію на противагу іншим, а до деяких із них політичні режими цих країн ставилися або терпимо, або вороже.

Для більшої частини території сучасної України в сенсі віросповідних свобод ситуація синхронізувалася з більшістю території Російської імперії, а згодом Радянського Союзу. Лише починаючи з часів горбачовської перебудови, коли ставлення до релігії, церкви і віруючих у різних частинах величезної держави почало змінюватися, а її церковна політика почала лібералізуватися, Україна отримала можливість сформулювати, а згодом уточнювати свою національну політику в галузі свободи совісті. Це було актуальне завдання правової системи України, оскільки країну буквально терзали міжцерковні конфлікти, найбільший з яких пов'язаний з виходом із підпілля Української греко-католицької церкви i ïï протистоянням з православними церквами та Римо-католицькою церквою.

Повноцінний Закон України "Про свободу совісті та релігійні організації" був прийнятий Верховною Радою України ще до проголошення України незалежною, він проіснував до наших днів без суттєвих змін [1]. Цей документ може вважатися доволі якісним, оскільки забезпечив відродження і розвиток релігійного середовища України. Саме він і ліг в основу українського законодавства про свободу совісті. Щоправда, сюди б слід також було віднести законодавчі та нормативноправові акти трьох українських урядів доби революційно-визвольних змагань УНР, Гетьманату та Директорії, оскільки саме вони лягли в основу Закону України "Про свободу совісті та релігійні організації" [1].

Наступною базовою складовою українського законодавства про свободу совісті стала конституційна норма щодо забезпечення прав громадян України на свободу совісті. Вона сформульована у вигляді ст. 35 чинної Конституції України [2]. Однак слід зазначити, що один із варіантів Конституції, який передував її появі, не мав цієї статті, що, можливо, свідчить про наявність спроби ії̈ авторів виокремити одну із діючих церков і надати їй особливого статусу. На щастя, цього не сталося.

Стаття 35 чинної Конституції України урівнює у правах громадян України незалежно від їх ставлення до релігії. Свобода світогляду і віросповідання ставить в один ряд віруючих і невіруючих, а також віруючих різних віросповідань. Таким чином, ця законодавча норма вирішує проблему ставлення до релігії та її сповідування як на особистісному рівні, так і на рівні організованих форм реального втілення цього права.

Далі у достатньо м'якій формі законодавець захищає інших громадян від посягань на їхню свободу у зв'язку з реалізацією свого права віруючими, включаючи й імпліцитно присутне право на захист від так званого “агресивного презелітизму” чи деструктивних впливів на людину з боку адептів тих чи інших релігійних культів, таких, наприклад, як “Біле Братство”, “Аум Сінрікьо” тощо.

DOI (Article): https://doi.org/10.36486/np.2019.2.01

(c) Bondarenko Viktor, 2019 
Крім цього, на особистісному рівні урегулювання питання рівного ставлення віруючими і невіруючими до виконання ними своїх обов’язків перед державою незалежно від їхніх релігійних переконань. Зокрема йдеться про виконання військового обов’язку. 3 цією метою дещо пізніше було прийнято Закон України "Про альтернативну службу" [3]. Цей Закон покликаний урегулювати давню проблему, що постала внаслідок безкомпромісності визначення “антисуспільної” поведінки з боку представників окремих релігійних організацій (християн віри євангельської, частини євангельських християн-баптистів, Свідків Сгови тощо), пов’язаної з їхньою відмовою від використання зброї під час проходження військової служби. Попри пояснення віруючими таких своїх дій віросповідними засадами, вони вважалися злочинними, кваліфікувалися і каралися за радянським законодавством як карний злочин. Проголосивши курс на демократію, Українська держава не могла залишити ці питання без відповідного законодавчого розв’язку у руслі того, як вони вирішувалися у демократичному світі.

Ключовою проблемою того часу було питання повернення релігійним організаціям культових споруд та іншого майна, що свого часу було насильницьким способом відібране у релігійних організацій і використовувалося не за призначенням. Така своєрідна часткова реституція церковної власності, що поволі розширювала свої межі, розпочалася у квітні 1992 р. з відповідного Указу Президента України, вона була фактично продубльована Президентом Л.М. Кравчуком напередодні президентських виборів 1994 р.

Вважали, що згаданий Указ є результатом наближення виборів, однак об’єктивно він спрямовувався на розв’язання надактуальної для релігійного середовища проблеми - повернення релігійним організаціям їхнього майна та будівель, що мали забезпечити досить швидке відродження релігійної мережі. Хоча усі керівники на місцях розуміли, що свого часу збудована людьми церква мала б використовуватися не як склад чи сільський клуб, а за прямим призначенням, однак організована Главою держави кампанія щодо їхнього повернення віруючим як законним власникам церковних будівель, відіграла свою мобілізуючу роль, хоча і відбулася далеко не бездоганно.

Разом із цими указами Глава держави зробив певні кроки до відновлення історичної справедливості щодо церков та релігійних організацій. Своїм Указом він установив для релігійних організацій плату за електроенергію на рівні тарифів для міського населення, тоді як за радянських часів законодавець, спрямований на винищення релігії, відносив релігійні організації і священство до розряду кустарних виробництв, що тягло за собою здирницькі тарифи та оподаткування заробітних плат.

У той час було видано ще один Указ Президента України, який шляхом утворення відповідних комісій, планував виробити пропозиції щодо повернення віруючим комплексів Софії Київської та Києво-Печерської Лаври. Як відомо, ці питання остаточно не вирішені й сьогодні, однак згаданий Указ Президента також відіграв позитивну роль, оскільки пролонгував розв'язання складних питань релігійного життя країни, поспішне розв'язання яких могло б призвести до загострення міжконфесійних та міжцерковних конфліктів, що були на той час відчутним дестабілізуючим фактором розвитку нашої країни і могли створити

DOI (Article): https://doi.org/10.36486/np.2019.2.01

(c) Bondarenko Viktor, 2019 
умови до ще більшого релігійного протистояння, а значить і до подальшого розколу українського суспільства [4].

Окремі автори, які вдавалися до аналізу подібного роду документів, щоправда, з політологічного погляду, схильні вбачати у діях влади (в особі Глави держави) політичну вигоду, оскільки більшість із цих документів побачили світ напередодні політичних кампаній [5]. 3 позиції права і правового аналізу таких документів, ми повинні оцінювати лише їхній вплив як правового регулятора на питання розвитку в Україні релігійних свобод, замирення існуючих конфліктів та розвиток свободи совісті.

Саме з цього погляду слід оцінювати Указ Президента, підписаний уже Президентом України Л.Д. Кучмою у березні 2002 р. "Про невідкладні заходи щодо остаточного подолання негативних наслідків тоталітарної політики колишнього Союзу РСР стосовно релігії та відновлення порушених прав Церков і релігійних організацій” [6].

Формально усі три згадані Укази були спрямовані на розв'язання однієї і тієї ж проблеми, і як такі можуть вважатися дублюючими документами. Однак очевидним є те, що вони забезпечили реалізацію трьох різних етапів одного процесу. Адже, якщо Указ 1992 р. дозволяв передачу колишніх культових будівель і майна їхнім законним власникам, уніфікуючи бачення цього питання з боку центральної і регіональних еліт, то Указ 1994 р. уже зобов’язував місцеві влади виконати цю роботу. Указ 2002 р. був своєрідною реакцією на довготривале невиконання місцевими і регіональними владами попередніх указів. Для активізації цього процесу при Кабінеті Міністрів України було утворено Міжвідомчу комісію, яка, по-перше, мала разом із релігійними організаціями виявляти непередані об'єкти церковної власності і, по-друге, зобов’язувати місцеве керівництво, якщо не передати ці об'єкти Церкві негайно то, принаймні, розробити логістичні кроки щодо їхньої передачі у недалекому майбутньому. Це все ще стосувалося сотень складних у фінансовому та організаційному плані випадків передачі тих об’єктів, у яких розташувалися господарські, культурно-побутові, медичні чи освітні заклади, а виселення яких вимагало значних ресурсних можливостей. За наступні два-три роки завдяки дії саме цього Указу урядовим структурам разом із місцевою владою вдалося зробити досить багато у царині відродження історичної справедливості щодо повернення Церкві її колишнього майна, відібраного у неї насильницьким шляхом.

У низці випадків Уряд України за дорученням Президента України чи за власною ініціативою вирішував й інші питання, розв'язання яких тією чи іншою мірою сприяло розвитку релігійного життя, а відтак і утвердженню віросповідних свобод та свободи совісті [7]. Внаслідок дій уряду були вирішенні питання церковного землевпорядкування, зниження тарифів на газопостачання, спрощено оподаткування та митне оформлення вантажів богослужбової літератури. Врегульована на нормативно-правовому рівні діяльність Міжвідомчої комісії з розмитнення, оподаткування, доставки та зберігання гуманітарної допомоги при КМ України також надала помітну допомогу тим, хто потребував підтримки. Головним отримувачем такої допомоги саме і стали релігійні організації, які за сприяння своїх одновірців із-за кордону змогли не лише суттєво покращити своє матеріальне

DOI (Article): https://doi.org/10.36486/np.2019.2.01

(c) Bondarenko Viktor, 2019 
становище, а й стати найбільш авторитетними фігурами у наданні гуманітарної допомоги світським освітньо-виховним, медичним і соціальним закладам.

Важливою подією релігійного життя країни стало утворення у кінці 1996 р. з ініціативи Президента України першої міжцерковної загальнонаціональної організації - Всеукраїнської Ради Церков і релігійних організацій (ВРЦО), згодом подібні секторальні організації були утворені протестантськими церквами, іншими релігійними організаціями, які з тих чи інших причин не могли потрапити до складу двох перших міжцерковних об'єднань.

Ці та інші міжрелігійні об'єднання уже могли ставити перед владою питання, що являли собою взаємний інтерес досить великих мас віруючих. Саме завдяки співпраці у цих міжрелігійних організаціях, віруючі та їхні лідери все краще і краще усвідомлюють спільність своїх інтересів та мають можливість консолідовано виступати на захист духовно-релігійних цінностей. Влада отримує відчутний зворотний зв’язок щодо своїх ініціатив або недоопрацювань у сфері релігійноцерковного життя, що забезпечує Україні відчутну іміджеву підтримку на міжнародній арені.

Важливу роль в організації виконання доручень вищих органів влади в галузі церковно-релігійного та забезпечення свободи совісті упродовж усього періоду незалежності відіграв державний орган у справах релігії. Він став генетичним послідовником утвореного ще у 1943 р. урядового органу - Ради у справах Руської православної церкви при Раді Міністрів СРСР, а згодом і УРСР [8]. Цей орган у різні часи входив до складу відповідних Міністерств або відомств, мав статус урядового або центрального органу виконавчої влади. Слід визнати, що найбільшою ефективністю у розв'язанні складних питань державно-церковних, міжцерковних та міжконфесійних проблем і проблем свободи совісті державний орган у справах релігій відіграв тоді, коли він працював у статусі центрального органу виконавчої влади. Однак за всіх обставин і статусу цього органу слід зазначити, що його вплив на релігійне життя та питання свободи совісті в Україні ніколи не мав надмірного характеру, оскільки в Україні, починаючи з доби Гетьманату, а згодом і в радянські часи, ніколи не було одноканального (лише через державний орган у справах релігій) зв'язку Церкви з державою. Церковне священноначалля завжди прагнуло виходити на спілкування з державно-владними структурами різних рівнів безпосередньо, що також стало виявом демократичності моделі державно-церковних відносин та забезпечення принципу свободи совісті в Україні.

За роки незалежності у нас було чимало випадків виходу у світ законодавчих та нормативно-правових документів, що мали суто політичний і ситуативний характер, та спрямовувалися не на розвиток свободи совісті, а на досягнення окремими політиками чи політичними силами електоральної підтримки. Однак лише у 90-х роках рішення політиків про підтримку тієї чи іншої Церкви (фактичний її підкуп) почали камуфлюватися під побудову храмів, спрямування державних коштів на ремонт і утримання церковно-монастирських комплексів, випуск релігійної літератури. 3 початком 90-х культових років підкуп мав характер прямих грошових перерахувань, з розрахунку на електоральну мобілізацію тієї чи іншої релігійної організації.

DOI (Article): https://doi.org/10.36486/np.2019.2.01

(c) Bondarenko Viktor, 2019 
Класичним прикладом таких прямих і непрямих підкупів Церков і релігійних діячів може слугувати протест Генеральної прокуратури України проти державної реєстрації УПЦ Київського Патріархату на вимогу Компартії України, за виборчими списками якої тодішній Генеральний прокурор пройшов до ВР України. Віктор Янукович, починаючи з 2004 р. і до кінця його правління, хоч і не корегував законодавство у бік згортання свободи совісті, однак відверто демонстрував однобоку симпатію, спрямовану у бік УПЦ Московського патріархату, ігноруючи при цьому усі інші, зокрема і найбільші церкви, такі як УПЦ Київського патріархату та УГКЦ. Він відверто ігнорував Всеукраїнську Раду Церков і намагався створити максимальне сприяння утвердженню в Україні “русского мира", проголошеного Патріархом Кирилом, РПЦ та УПЦ Московського патріархату. Його намагання поглибити поділ країни на "своїх" і “чужих" за релігійною та мовною ознакою багато в чому сприяв її розділенню і підводив до глибокого внутрішнього конфлікту, що слугувало початком відкритого втручання Росії у внутрішні справи України, анексії Криму, війни на Донбасі і безславного кінця президенства В. Януковича.

Суспільно-політичне збурення кінця 2013 - початку 2014 рр., що отримало назву “Революції гідності", призвело до нової напруженості у релігійному середовищі, що потребувало серйозної юридичної оцінки та правового регулювання. До початку 2018 р. питання релігійного життя не викликали у політичного керівництва України, очолюваного Президентом П. Порошенком, жодного інтересу. Певну, чисто фахову активність у цьому відношенні проявили лише окремі депутати Верховної Ради України, які з професійного інтересу просували окремі важливі питання розвитку свободи совісті у нашій країні. Так, завдяки їм, були розв'язані проблеми дозволу релігійним організаціям на відкриття світських навчальних закладів, зрівнянні в правах дипломи про світську і духовну освіту та дипломи про вчені звання, розв'язана проблема діяльності капеланів (військового духовенства) в армії та інших силових відомствах, хоча закон “Про капеланство” і не було прийнято.

Ці та інші ініціативи окремих представників вищого законодавчого органу країни відіграли значну роль у зміцненні свободи совісті в Україні. Однак найбільшою ініціативою Верховної Ради України стала підтримка звернення президента П. Порошенка до Вселенського Патріарха стосовно дарування православним в Україні автокефального статусу.

Експертне середовище з самого початку розв'язання багаторічної проблеми українського православ'я, що полягала у нелегітимному, з позиції церковних канонів, започаткування церковної незалежності від Москви, відзначило неабиякий темп перебігу подій у цій царині відтоді, як до справи узявся Вселенський Патріарх Варфоломій. Хоча зовні нічого помітного не відбулося у взаєминах Вселенської і Московської патріархій в “українському питанні”, однак воно стрімко пішло до своєї розв'язки.

Не будемо у цьому випадку будувати здогадки, що стало каталізатором такого швидкого розв'язання багаторічної проблеми, а краще оцінимо ту "майстерність”, з якою Президент П. Порошенко взяв вирішення цієї проблеми на себе і таки розв’язав іiі. Мрії десятків поколінь українців, які прагнули унеза-

DOI (Article): https://doi.org/10.36486/np.2019.2.01

(c) Bondarenko Viktor, 2019 
лежнення православних в Україні, допомогли П. Порошенку у найкоротші терміни завершити процес отримання автокефалії православними українцями. Ця давноочікувана акція стала також одним із провідних моментів його політики на виборах Президента України 2019 р.

Ми розглянемо правові підстави розв'язання цієї проблеми. В історії православних країн було чимало випадків, коли світські правителі сприяли утвердженню автокефалії православної церкви у своїх країнах. Так, у різні часи було в історії Грузинської, Сербської, Елладської та інших Церков. Це завжди вважалося нормальною практикою, коли церковні справи тісно ув'язувалися зі справами політичними. Ще у 2008 р. Вселенський Патріарх Варфоломій наголошував, що у низці випадків “Церква-Мати погоджувалася з вимогою урядів новостворених держав із православним населенням на Балканському півострові щодо надання автокефалії церквам, які виходили з ії̈ канонічної юрисдикції, а саме Грецькій (1850), Сербській (1831), Болгарській (1945) та Албанській (1937), дарма, що це спричинило різке звуження церковної юрисдикції Константинопольського патріархату [10].

Цим самим Константинопольський патріарх, з одного боку, демонстрував своєму московському колезі, що інтереси православ'я вищі за намагання будьякою ціною утримувати свою владу над церквами, які прагнули до самостійності, а 3 другого, - виправдовував це прагнення віруючого люду і політиків, які домагалися духовного звільнення свого народу. Виходячи з таких позицій, ніхто не може стверджувати, що Петро Порошенко, надаючи сприяння у становленні автокефалії православних в Україні, порушив Конституцію чи інші закони України, або церковно-канонічне право. Тому звернення Президента України до Вселенського Патріарха з приводу надання автокефалії православним в Україні, підтримане Верховною Радою України, є цілком позитивними політичними актами, що були спрямовані на унормування цієї важливої проблеми і стали виявом турботи про зміцнення права людини на свободу совісті [11].

Однак з погляду наслідків згаданих подій та отримання православними українцями Томосу про автокефалію їхньої Церкви, це слід розглянути з іншого боку. Об'єктивно вони б мали сприяти єднанню нашої країни та українського суспільства, злиттю локальних ідентичностей українців, що живили міжправославний конфлікт усі ці роки, в одну загальноукраїнську ідентичність, що стала б основою єдиної помісної православної церкви в Україні.

Проте, говорячи про об'єднання православних в Україні, ми не маємо справу з грою вільних суспільних сил і настроїв, адже досягненню цієї мети активно протистоїть Руська православна церква й ті сили в Росії, які не бажають відходу України від Москви як духовно-релігійного центру. Українська ж влада, очолювана Президентом України П. Порошенком не змогла перетворити справу творення нової церкви на реальне об'єднання УПЦ Київського Патріархату, УАПЦ та УПЦ Московського Патріархату. Більше того, своїми незграбними діями вона призвела до того, що у цьому процесі практично не взяла участь найбільша гіпотетична учасниця цього процесу УПЦ МП. Поспішність та непрофесіоналізм дій влади, пов’язані з необхідністю уплітання теми отримання автокефалії православних в Україні у процес виборів нового Глави нашої держави, стали тією ціною,

DOI (Article): https://doi.org/10.36486/np.2019.2.01

(C) Bondarenko Viktor, 2019 
котру наш народ заплатив за спробу активної політизації цього питання Президентом П. Порошенком та його оточенням. Сегментованість українського соціуму у питанні унезалежнення православних не лише не зменшилася, а навіть зросла, заважаючи єднанню наших громадян, українського суспільства і держави. Подальша експлуатація питання автокефалії у політичних цілях призвела до ще більш плачевних наслідків, пов’язаних не лише з провалом “Томос-туру”, а й з внутрішніми проблемами у новоствореній Церкві.

На процес творення нової Церкви, негативно вплинув і загальний правовий нігілізм, що характеризував діяльність постмайданної влади. 3 одного боку, дії Глави держави та його найближчого оточення у питанні отримання автокефалії не лише не були хоча б якоюсь мірою публічними, а мали відверто утаємничений і кулуарний характер. Це позбавило його справжньої суспільної підтримки, а відтак і відповідного ефекту у справі переборювання кризи національної самоідентифікації населення України у питанні віросповідної приналежності. Зроблене не принесло помітної політичної користі й самому Петру Порошенку, оскільки його дії у справі об’єднання православних в Україні мали відверто антуражний характер.

Сказане підтверджує і прийняття Верховною Радою України двох Законів України, спрямованих на врегулювання ситуації у православному середовищі країни. Ідеться про закони України від 26.09.2016 № 5309 та від 16.01.2019 № 4128 [12]. Згадані закони мають різну природу, а, відповідно, і наслідки для розвитку свободи совісті та релігійних організацій. Якщо Закон України від 16.01.2019 № 4128 має на меті врегулювати механізм переходу релігійних організацій із однієї юрисдикції в іншу, то Закон України від 26.09.2016 № 5309 зобов’язує релігійні організації, що входять до складу УПЦ в єдності з Московським патріархатом, внести корекцію у власну назву, зафіксувавши в той чи інший спосіб приналежність до Московського Патріархату. Це ж стосується і ще чотирьох Церков.

Обидві цілі є абсолютно досяжними, однак, якщо перша з них спрямована на недопущення ескалації конфліктності у зв’язку зі зміною парафіями, монастирями, місіями, братствами, єпархіальними управліннями та самою Київською митрополією УПЦ своєї юрисдикційної приналежності, то другий Закон у цілому спрямовується на розв’язання доволі уявної проблеми - зміни її назви. Ще раз наголосимо, що виконання цього завдання до снаги державі, однак очевидно, що очікуваного ефекту, пов'язаного з появою у назві УПЦ чіткої прив'язки до Московського Патріархату, вочевидь не буде.

Ні для кого не є таємницею той факт, що УПЦ є великою митрополичою областю РПЦ, наділеною правами так званої широкої автономії, що справді нагадує за обсягом дарованих їй прав окрему самостійну Церкву. Однак вона була і є невід'ємною частиною РПЦ, що лише має іншу назву “Українська Православна Церква”, визначену ще на архієрейському соборі РПЦ у 1990 р. та підтверджену чинними Статутами РПЦ та УПЦ. Інформація про це є у відкритому доступі, а відтак перейменування УПЦ у законодавчому порядку є більшою мірою пропагандистським кроком, спрямованим на публічне визнання реального статусу УПЦ як складники РПЦ. Саме ж перейменування мало що дасть у сенсі суспільного розуміння її реального статусу і лише загальмує, на нашу думку, процес переходу релігійних організацій з УПЦ до ПЦУ.

DOI (Article): https://doi.org/10.36486/np.2019.2.01

(C) Bondarenko Viktor, 2019 
Єдиною, безсумнівно, вірною нормою цього Закону є вимога щодо недопущення священства УПЦ до капеланського служіння у ЗСУ та інших силових відомствах країни. Решта ж норм закону у результаті його виконання особливої користі не принесуть, а от відчуття ворожості у відносинах між двома церквами вони посіють, а відтак і все українське суспільство не сприйме зазначений Закон як акт, скерований на встановлення справедливості. Основою для такої суспільної оцінки цього Закону, насамперед, стане те, що подібні вимоги не висувалися законодавцем до інших суб'єктів господарчої, фінансової та іншої діяльності організацій та установ РФ на території України.

Закон України від 16.01.2019 № 4128 вкрай необхідний, але також не є досконалим. Його найбільша вада у тому, що у ньому не прописаний дієвий механізм легітимації переходу релігійних організацій з однієї юрисдикції в другу. У низці випадків це породжує проблеми, особливо в ситуаціях, коли парафія не має однозначної позиції щодо зміни юрисдикції. Законодавцеві слід було б також передбачити питання, пов’язані з облаштуванням релігійної діяльності обох частин колись єдиної громади - почергові богослужіння, використання пристосованих приміщень, будівництва нових храмів тощо. Такі подробиці міг би розробити Кабінет Міністрів за дорученням Верховної Ради.

Проведення такої роботи вказало б віруючим, по-перше, на загальний тренд державних пріоритетів у галузі релігійного життя, а по-друге - не створило б у релігійному середовищі і у суспільстві в цілому відчуття непримиренності, поділу на “своїх” і “чужих”, що замість очікуваної консолідації православного середовища лише роз’єднує народ. Причиною такого стану речей стала надмірна політизація “православного питання” в Україні.

Як уже зазначалося, релігійне середовище в Україні понад двадцять років динамічно розвивається, а правові основи релігійних свобод та свободи совісті зміцнюються. Однак тут залишається ще чимало питань, які потребують свого вирішення. Українських правників, які разом із церковними юристами шукають шляхи удосконалення вітчизняного законодавства щодо свободи совісті, понад усе турбують питання законодавчого забезпечення повернення Церкви як суспільного інституту до стану системного елементу сучасної системи соціальної будови українського суспільства. Це означає, з одного боку, на законодавчому рівні мають бути подолані усі установки на маргіналізацію Церкви, що виробилися в умовах комуністичного режиму. 3 другого ж боку, це дозволить перетворити Церкву на рядопокладений суб'єкт правовідносин та убезпечити суспільство від можливих виявів клерикалізму.

Найближчим часом також слід було б прийняти закон “Про капеланство” 3 метою зміцнення цього надзвичайно важливого суспільного інституту, покликаного не просто сприяти роботі з патріотичного виховання та психологічної підтримки військовослужбовців, а виконувати місію духовно-релігійного окормлення солдатів і офіцерів та допомагати боротися з наслідками війни i, передусім, із пост-травматичним синдромом воїнів, які пройшли через бойові дії.

Слід також розширювати правові можливості для поглиблення соціальної роботи Церкви і дозволити релігійним організаціям брати участь у державних тендерах, що проводяться у сфері соціальних послуг; забезпечити тіснішу співпрацю

DOI (Article): https://doi.org/10.36486/np.2019.2.01

(C) Bondarenko Viktor, 2019 
Церкви зі світською школою, при безумовному збереженні світського характеру останньої; передусім це стосується можливого часткового виконання Церквою функцій догляду та виховання дошкільнят та участі Церкви у відродженні позашкільної освіти, що функціонувала б на безкоштовній основі; слід також законодавчо забезпечити участь Церкви у збереженні традиційних сімейних цінностей і сім'ї як такої разом із державними органами опіки над сім'єю тощо.

I, насамкінець, варто на законодавчому рівні переглянути радикальне прочитування конституційної норми щодо відокремлення Церкви від держави в частині заборони фінансової підтримки Церкви з боку держави. У багатьох країнах, де цей конституційний принцип також присутній у основному законі цих країн, держава надає Церкві відчутну підтримку у справі її основної діяльності, оскільки вона визнається корисною для суспільства і окремої особи. Фінансується також утримання сакральних пам'яток архітектури, які знаходяться у користуванні Церкви, фінансово підтримується державою духовенство, яке працює на депресивних територіях, держава бере дольову участь у будівництві храмів, оплачує викладання загальноосвітніх дисциплін у світських навчальних закладах, що діють під патронатом Церкви тощо.

Отже, зважаючи на зазначене, можемо констатувати, що саме правові механізми є далеко не вичерпними і найефективнішими засобами зміцнення релігійного середовища та забезпечення свободи совісті у сучасній Україні.

\section{СПИСОК ВИКОРИСТАНИХ ДЖЕРЕЛ}

1. Про свободу совісті та релігійні організації: Закон України від 23.04.1991 № 987-XII. URL: htfps//zakon.nade, dov.ua (дата звернення: 16.04.2019).

2. Конституція України: Закон України від 28.06.1996 № 254к/96-ВР. Ст. 35.

3. Про альтернативну (невійськову) службу: Закон України від 12.12.1991 № 1975-XII. Відомості ВР України, 1992. № 15. Ст. 188.

4. Про заходи щодо повернення релігійним організаціям культового майна: Указ Президента України від 4 березня 1992 року № 125/б; Про невідкладні заходи щодо остаточного подолання негативних наслідків тоталітарної політики колишнього Союзу РСР стосовно релігії та відновлення порушених прав церков і релігійних організацій: Указ Президента України від 21 березня 2002 року № 279.

5. Єленський В.С. Велике повернення: релігія у глобальній політиці та міжнародних відносинах кінця XX - початку XXI століття. Львів: Вид-во Львів. католицького ун-ту, 2013. С. 454-455.

6. Про невідкладні заходи щодо остаточного подолання наслідків тоталітарної політики колишнього Союзу РСР стосовно релігії та відновлення порушених прав Церков і релігійних організацій: Указ Президента України від 21 березня 2004 р. № 279.

7. Уряд України має намір вирішити складні питання державно-церковних відносин. Юлія Тимошенко. URL: www.irs.in.ua (дата звернення: 16.04.2019).

8. Хаварівський У.Б. Інституалізація державно-церковних відносин в Україні: історикоуправлінський аспект. Тернопіль: Вид-во “Терно-граф”, 2013. С. 320.

9. Генеральна прокуратура України опротестувала законність реєстрації УПЦ КП і призупинила дію акту її реєстрації 1992 року. URL: www.ortodox.org.uа (дата звернення: 16.04.2019).

10. Звернення Його Всесвятості Патріарха Константинопольського Варфоломія I до української нації (26 липня, 2008). URL: https: //risu.org.ua (дата звернення: 16.04.2019).

11. Саган Олександр. Православна Церква України: конституювання та перспективи розвитку. К.: Тов. “Софія-А” ЛТД. С. 80-82.

12. Про внесення змін до Закону України "Про свободу совісті та релігійні організації щодо назви релігійних організацій (об’єднань), які входять до структури (є частиною) релігійної організації (об’єднання), керівний центр (управління) якої знаходиться за межами України в державі, яка законом визнана такою, що здійснила військову агресію проти України та (або

DOI (Article): https://doi.org/10.36486/np.2019.2.01

(c) Bondarenko Viktor, 2019 
тимчасово окупувала частину території України)”: Закон України від 26.09.2016 № 5309; Про внесення змін до деяких законів України щодо підлеглості релігійних організацій та процедури державної реєстрації релігійних організацій із статусом юридичних осіб: Закон України від 16.01.2019 № 4128.

\section{REFERENCES}

1. Pro svobodu sovisti ta relihiini orhanizatsii. "On Freedom of Conscience and Religious Organizations": Law of Ukraine of 23.04.1991 No. 987-XII. URL: htfps // zakon.nade, dov.ua (date of application: 16.04.2019) [in Ukrainian].

2. Konstytutsiia Ukrainy. "Constitution of Ukraine": Law of Ukraine of June 28, 1996 No. 254k / 96-VR, Art. 35 [in Ukrainian].

3. Pro alternatyvnu (neviiskovu) sluzhbu. "On alternative (non-military) service": Law of Ukraine of December 12, 1991 No. 1975-XII. Verkhovna Rada of Ukraine, 1992. No. 15. Art. 188 [in Ukrainian].

4. Pro zakhody shchodo povernennia relihiinym orhanizatsiiam kultovoho maina "On Measures to Return Religious Organizations to Religious Organizations": Presidential Decree No. 125/b of March 4, 1992; Pro nevidkladni zakhody shchodo ostatochnoho podolannia nehatyvnykh naslidkiv totalitarnoi polityky kolyshnoho Soiuzu RSR stosovno relihii ta vidnovlennia porushenykh prav tserkov i relihinykh orhanizatsii "On urgent measures to finally overcome the negative consequences of the former Soviet Union's totalitarian policy on religion and restore the violated rights of churches and religious organizations": Presidential Decree No. 279 of March 21, 2002 [in Ukrainian].

5. Yelenskyi V.Ye. (2013) Velyke povernennia: relihiia u hlobalnii politytsi ta mizhnarodnykh vidnosynakh kintsia XX - pochatku XXI stolittia. The Great Return: Religion in Global Politics and International Relations at the End of the 20th and 21th Centuries. Lviv: View of Lviv. Catholic University. P. 454-455 [in Ukrainian].

6. Pro nevidkladni zakhody shchodo ostatochnoho podolannia naslidkiv totalitarnoi polityky kolyshnoho Soiuzu RSR stosovno relihii ta vidnovlennia porushenykh prav Tserkov i relihiinykh orhanizatsii. "On urgent measures to finally overcome the consequences of the former Soviet Union's totalitarian policy on religion and restore the violated rights of Churches and religious organizations": Presidential Decree of March 21, 2004 No. 279 [in Ukrainian].

7. Uriad Ukrainy maie namir vyrishyty skladni pytannia derzhavno-tserkovnykh vidnosyn. Yuliia Tymoshenko. "The Government of Ukraine intends to resolve complex issues of state-church relations. Yulia Timoshenko. URL: www.irs.in.ua (date of application: 16.04.2019) [in Ukrainian].

8. Khavarivskyi U.B. (2013) Instytualizatsiia derzhavno-tserkovnykh vidnosyn v Ukraini. "Institutionalization of state-church relations in Ukraine: historical and managerial aspect. Ternopil: Publ. "Terno-hraf", 320 p. [in Ukrainian].

9. Heneralna prokuratura Ukrainy oprotestuvala zakonnist reiestratsii UPTS KP i pryzupynyla diiu aktu yii reiestratsii 1992 roku. "The Prosecutor General's Office of Ukraine contested the lawfulness of registration of the UOC KP and suspended the act of its registration in 1992" URL: www.ortodox.org.ua (date of application: 16.04.2019) [in Ukrainian].

10. Zvernennia Yoho Vsesvyatosti Patriarkha Konstantynopolskoho Varfolomiia I do ukrainskoi natsii (26 lypnia, 2008). "Appeal of His Holiness Patriarch Bartholomew I to the Ukrainian Nation" (July 26, 2008). URL: https: //risu.org.ua (date of application: 16.04.2019) [in Ukrainian].

11. Sahan Oleksandr. Pravoslavna Tserkva Ukrainy: konstytuyuvannya ta perspektyvy rozvytku. "The Orthodox Church of Ukraine: constitution and development prospects". K.: company "Sofia-A" LTD. P. 80-82 [in Ukrainian].

12. Pro vnesennia zmin do Zakonu Ukrainy "Pro svobodu sovisti ta relihiini orhanizatsii shchodo nazvy relihiinykh orhanizatsii (obiednan), yaki vkhodiat do struktury (ye chastynoiu) relihiinoi orhanizatsii (obiednannia), kerivnyi tsentr (upravlinnia) yakoi znakhodytsia za mezhamy Ukrainy v derzhavi, yaka zakonom vyznana takoiu, shcho zdiisnyla viyskovu ahresiiu proty Ukrainy ta (abo tymchasovo okupuvala chastynu terytorii Ukrainy)" "On Amendments to the Law of Ukraine "On Freedom of Conscience and Religious Organizations on the Name of Religious Organizations (Associations) That Are in the Structure (Part of) a Religious Organization (Association), whose Headquarters (Management) is located outside Ukraine in a state recognized by law as having carried out military aggression against Ukraine and (or temporarily occupying part of the territory of Ukraine)" Law of Ukraine of 26.09.2016 No. 5309; Pro vnesennia zmin do deiakykh zakoniv Ukrainy

DOI (Article): https://doi.org/10.36486/np.2019.2.01

(C) Bondarenko Viktor, 2019 
shchodo pidlehlosti relihiynykh orhanizatsii ta protsedury derzhavnoi reiestratsii relihiynykh orhanizatsii iz statusom yurydychnykh osib. "On Amendments to Some Laws of Ukraine Concerning the Subjectivity of Religious Organizations and the Procedure for State Registration of Religious Organizations with the Status of Legal Entities". Law of Ukraine dated 16.01.2019 No. 4128 [in Ukrainian].

UDC 322

Bondarenko Viktor,

Doctor of Philosophical Sciences, Professor, Chief Researcher, State Research Institute MIA Ukraine, Kyiv, Ukraine

ORCID ID 0000-0003-4251-3448

\section{FREEDOM OF CONSCIENCE AS AN OBJECT OF LEGAL REGULATION IN MODERN UKRAINE}

The article substantiates the ideas that despite the functioning in Ukraine of the constitutional principle of separation of the Church from the state, and the school from the Church, and other legal mechanisms remain the determining lever, provides further development of the religious milieu, assertion of freedom of conscience and productive state-church relations.

Ukrainian lawyers, who together with church lawyers are looking for ways to improve the domestic legislation on freedom of conscience, are most concerned about the legislative support of the return of the Church as a public institution in the state of a systemic element of the modern social structure of Ukrainian society. This means, on the one hand, that all attitudes to the marginalization of the Church must be overcome at the legislative level and developed under the communist regime. On the other hand, this will make it possible to turn the Church into a subject of legal relations and to protect society from possible manifestations of clericalism.

In the near future, it would also be advisable to adopt the law "On Chaplain" in order to strengthen this extremely important public institution, which is designed not only to contribute to the work of patriotic education and psychological support of military personnel, but also to carry out the mission of spiritual and religious registration of soldiers and officers and to help combat the consequences of the war and, above all, the post-traumatic syndrome of soldiers who have gone through military operations.

It is also necessary to expand the legal possibilities for deepening the social work of the Church and to allow religious organizations to participate in public tenders in the field of social services; to ensure closer collaboration of the Church with the secular school, while preserving the secular character of the latter unconditionally, especially with regard to the possible partial performance by the Church of the functions of care and education of preschoolers and the participation of the Church in the revival of out-of-school education.

Finally, a radical interpretation of the constitutional norm on the separation of the Church from the state should be reconsidered at the legislative level in order to prohibit financial support of the Church by the state. In many countries where this

DOI (Article): https://doi.org/10.36486/np.2019.2.01

(c) Bondarenko Viktor, 2019 
DOI (Issue): https://doi.org/10.36486/np.2019.2 Issue 2(44) 2019

constitutional principle is also present in the basic law, the state provides tangible support to the Church in its core activities, as long as it is recognized as beneficial to society and the individual.

So, granting this information, it is possible to state that the legal mechanisms are the most effective means of strengthening the religious environment and ensuring freedom of conscience in modern Ukraine.

Keywords: the principle of freedom of conscience, Ukrainian legislation on freedom of conscience, ensuring natural human rights, Ukraine as a secular state, legislative support of the unity of the Orthodox in Ukraine, the subjectivity of the Ukrainian churches, autocephaly of the Orthodox as an attribute of the Orthodox states.

Отримано 07.06.2019 
Чисников Владимир Николаевич, доктор юридических наук, доцент, главный научный сотрудник ГНИИ

МВД Украины, г. Киев, Украина

ORCID ID 0000-0003-2020-7298

\section{НОРМАТИВНО-ПРАВОВОЕ РЕГУЛИРОВАНИЕ ВНУТРЕННЕГО (АГЕНТУРНОГО) НАБЛЮДЕНИЯ В ОРГАНАХ ПОЛИТИЧЕСКОГО СЫСКА РОССИЙСКОЙ ИМПЕРИИ НАЧАЛА ХХ В.: НЕКОТОРЫЕ ДИСКУССИОННЫЕ ВОПРОСЫ СОВРЕМЕННОЙ ИСТОРИОГРАФИИ}

В статье проанализировань дискуссионнье положения инструкций Департамента полищии МВД Российской империи (1907, 1914, 1916 г2.) и Московского охранного отделения (1911) по организации и ведению внутреннего (агентурного) наблюдения. Автор делает вывод, что в начале XX века главным и единственным нормативно-правовым актом по работе с секретной агентурой до кониа существования Российской империи была "Инструкция по организации и ведению внутреннего (агентурного) наблюдения” (1907), а издаваемые Департаментом полиции циркуляры по этим вопросам лишь развивали и закрепляли основные ее положения.

Ключевые слова: Департамент полиции, инструкции по внутреннему наблюдению (1907, 1911, 1914, 1916 г2.), политический сыск, история ОРД.

У статті проаналізовано дискусійні положення інструкцій Департаменту поліціі МВС Російської імперії (1907, 1914, 1916 рр.) і Московського охоронного відділення (1911) щодо організації та ведення внутрішнього (агентурного) спостереження. Автор робить висновок, що на початку XX століття головним $i$ єдиним нормативно-правовим актом по роботі з секретною агентурою до кіния існування Російської імперії була "Інструкція з організацї та ведення внутрішнього (агентурного) спостереження” (1907), а циркуляри Департаменту поліції з щъого питання лише розвивали та закріплювали основні ї̈ принщипи.

Ключові слова: Департамент полічї, інструкцї̈ по внутрішньому спостереженню (1907, 1911, 1914, 1916 рр.), політичний сиск, історія ОРД.

Основным методом деятельности политического сыска Российской империи в начале XX столетия было внутреннее (агентурное) наблюдение. Не случайно в “Инструкции по организации и ведению внутренней агентуры”, составленной при Московском охранном отделении (1911), подчеркивалось: “Единственным и вполне надежным средством, обеспечивающим осведомленность разыскного органа, является внутренняя агентура” (§ 1) [1, с. 23]. Следует также согласиться с мнением

DOI (Article): https://doi.org/10.36486/np.2019.2.02

(C) Chysnikov Volodumyr, 2019 
одного из известных деятелей политического сыска царской России П.П. Заварзина, который писал: “...Возможно ли обойтись без внутренней агентуры и чем ее заменить? Таков важнейший вопрос по работе политического и уголовного розыска. Ответ определенный. Ничем ее заменить нельзя, а потому она необходима и существует во всех без исключения странах мира. Без разыскного органа ни одно государство не существовало и существовать не будет” [2, с. 21].

В современных условиях использование негласного аппарата при раскрытии и расследовании преступлений было и остается одним из наиболее эффективнейших методов борьбы правоохранительных органов с преступностью. В Украине, как и во многих странах мира, существует определенная нормативно-правовая база (законы, постановления правительства, ведомственные акты, инструкции и т.д.), которая регламентирует основы функционирования агентуры и ее участия в предупреждении и раскрытии преступлений [3, с. 8].

Одним из источников повышения эффективности деятельности сотрудников оперативных служб может стать изучение исторического опыта их предшественников, в том числе и нормативно-правовой базы, регламентировавшей работу политической полиции Российской империи с тайной агентурой.

Проблемой изучения нормативно-правовых актов (в частности инструкций) по организации и ведению внутреннего наблюдения в жандармских и разыскных учреждениях исследователи начали заниматься сразу после падения царского самодержавия в феврале 1917 года. Этот процесс продолжается и поныне.

Первыми исследователями по данной тематике были: В.К. Агафонов, В.Б. Жилинский, С.Г. Сватиков, М.А. Цявловский., С.Б. Членов, П.Е. Щеголев и др. В дальнейшем отдельные аспекты инструкций затрагивались в работах современных российских и украинских авторов: А.В. Борисова, С.А. Воронцова, С.Н. Галвазина, С.П. Дресвянина, С.Н. Жарова, В.М. Жухрая, А.В. Козиной, А.П. Кошеля, Ф.М. Лурье, В.Я. Мацюка, Р.С. Мулукаева, В.А. Некрасова, З.И. Перегудовой, В.И. Полубинского, И.С. Розенталь, М.А. Самелюка, М.П. Смирнова, И.В. Тарасюк, В.Ф. Усенко, А.В. Федорова, В.В. Ченцова,В.Н. Чисникова, А.В. Шахматова, Д.И. Шинджикашвили, А.Ю. Шумилова, Е.И. Щербаковой, А.Н. Ярмыша и др.

Если проанализировать историческую, историко-правовую и специальную литературу, то в ней упоминается несколько жандармско-полицейских инструкций, которые регламентировали работу с агентурой по политическому розыску. Прежде всего это: "Инструкция по организации и ведению внутреннего (агентурного) наблюдения” (1907), “Инструкция по организации и ведению внутренней агентуры”, составленная при Московском охранном отделении (1911), "Инструкция по организации и ведению внутреннего наблюдения в жандармских и розыскных учреждениях" (1914) и “Наказ по ведению политического розыска" (1916). Полные тексты всех указанных выше нормативных актов в настоящее время опубликованы [4], [5, с. 214-264], [6, с. 96-150], [1, с. 40-98 ].

Заметим, что среди исследователей нет единого мнения относительно количества и времени издания некоторых инструкций. Если судить по публикациям, то только “московских" инструкций насчитывается три: 1908, 1911 и 1914 годов, что не соответствует действительности. В научных работах также нередко

DOI (Article): https://doi.org/10.36486/np.2019.2.02

(c) Chysnikov Volodumyr, 2019 
встречаются факты, когда авторы, говоря о департаментских инструкциях 1907 и 1914 гг., цитируют “московскую” инструкцию или наоборот [7]. Не выяснена до конца и судьба департаментской инструкции 1914 года, полный текст которой до недавнего времени оставался неопубликованным и, как справедливо замечает профессор 3.И. Перегудова, вопрос об инструкциях “не так прост, как может показаться" [8, с. 213].

Так сколько же было жандармско-полицейских инструкций по работе с агентурой? Именно на этот вопрос автор и попытается дать ответ.

Для начала рассмотрим каждый из названных документов в отдельности, обратившись в первую очередь к первоисточникам.

Итак, первым обобщающим ведомственным нормативным актом, который регламентировал организационно-тактические аспекты деятельности политической полиции Российской империи с внутренней агентурой, была "Инструкция по организации и ведению внутреннего (агентурного) наблюдения” (1907), утвержденная министром внутренних дел П.А. Столыпиным. Состояла она из 41 параграфа [9] и создавалась сотрудниками особого отделения Департамента полиции под непосредственным руководством директора Департамента полиции М.И. Трусевича [10, с. 218]. Одним из основных составителей инструкции был жандармский полковник А.М. Еремин, прикомандированный к Департаменту полиции. Много поправок и дополнений к инструкции внес исполняющий обязанности начальника Московского охранного отделения Е.К. Климович, который привлекался департаментом в качестве рецензента [8, с. 203].

Некоторые исследователи относят к числу составителей П.И. Рачковского [11, с. 148] и С.В. Зубатова [12, с. 40], но эти утверждения являются голословными и не подтверждены архивными источниками. Правильнее будет сказать, что указанные лица, а также сотрудник Особого отдела Г М. Трутков были одними из инициаторов создания этой инструкции. Именно они в начале XX века в своих докладных записках ставили перед руководством Департамента полиции вопрос о постановке “дела внутренней агентуры... на надлежащую высоту" [8, с. 195]. Подтверждением тому является утверждение жандармского генерала М.С. Коммисарова о том, что начало выработки инструкции по работе с агентурой началось в 1902-1903 гг. [10, с. 145].

10 февраля 1907 года Инструкция в комплексе с другими нормативными материалами (инструкциями по наружному наблюдению и т.д.) была направлена Департаментом полиции начальникам районных охранных отделений (в этот период в России было организовано 8 районных охранных отделений). При этом в сопроводительном письме указывалось, что данная инструкция должна храниться лично у начальника разыскного органа, без права копирования и “исключительно для личного руководства и для того, чтобы служить конспектом при разъяснениях оснований ведения внутренней агентуры лицам, стоящим во главе розыска” [13, c. 62].

Как предполагают исследователи, количество отпечатанной инструкции не превышало десяти экземпляров и хранились они в условиях строжайшей конспирации. Поэтому не случайно, что такой исключительный порядок хранения позволил Департаменту полиции сохранить ее содержание в глубокой тайне от рево-

DOI (Article): https://doi.org/10.36486/np.2019.2.02

(c) Chysnikov Volodumyr, 2019 Issue 2(44) 2019 http://naukaipravoohorona.com/ 
люционеров, и ни один экземпляр, в отличии от инструкции по наружному наблюдению [14], не попал в их руки.

Впервые цитировать совершенно секретную “столыпинскую” инструкцию по работе с агентурой начали после свержения самодержавия, на заседаниях Чрезвычайной следственной комиссии Временного правительства. Так, допрашивая 24 мая 1917 года бывшего вице-директора Департамента полиции С.Е. Виссарионова, председатель ЧСК зачитывал пространные выдержки из §§ 5, 8, 9 и 23 “столыпинской” инструкции 1907 г. [10, с. 449-450; 452-453]. Поэтому следует возразить С.Н. Жарову, который утверждает, что даже ЧСК не имела в своем распоряжении ни одного экземпляра указанного нормативного акта [6, 32]. Сохранился даже протокол от 2 июня 1917 года, составленный следователем ЧСК Н.А. Колоколовым о том, что он в присутствии понятых осмотрел обнаруженную в Департаменте полиции "Инструкцию по организации и ведению внутреннего (агентурного) наблюдения", никем не подписанную, отпечатанную на машинке, совершенно секретную и состоящую из 41 параграфа [15]. Речь, безусловно, идет о “столыпинской” инструкции 1907 года.

Впервые отдельные фрагменты первой департаментской инструкции появились в печати в 1918 году в книге В.К. Агафонова “Заграничная охранка” [16, 187-188; 195-199], изданной в Петрограде. Полный же ее текст был опубликован в том же году в Ростове-на-Дону в книге С.Г. Сватикова "Русский политический сыск за границей” [17]. В 1941 году она была переиздана под грифом “для служебного пользования” и предназначалась для сотрудников НКВД [18]. Широкая читательская аудитория ознакомилась с указанной инструкцией лишь в 1992 году после публикации З.И. Перегудовой [4].

Что касается даты составления этой инструкции - 1907 год, то, по утверждению 3.М. Перегудовой, именно ей и Ф.М. Лурье "удалось установить точную дату создания [этого] документа” во время совместной работы над статьей “Царская охранка и провокация”. При этом автор ссылается на публикацию С.Г. Сватикова, где в примечаниях к инструкции указывалось: "Ни имя составителя, ни время издания инструкции неизвестны. Некоторые особенности дела, в котором она хранится, дают основание говорить, что в ее разработке принимал участие Рачковский, и издана она была до 1911 г.” [8, с. 202-203].

Позволим себе не согласиться с “новацией” указанных авторов и заявить, что точный год издания инструкции - 1907 был установлен еще во время работы ЧСК Временного правительства. Приведем диалог, прозвучавший во время допроса 26 апреля 1917 года жандармского генерала А.В. Герасимова:

“...Председатель. - Не помните ли вы, что была выработана целая инструкция, обязательна для начальников Охранных отделений. Она содержала в себе разработанную систему поведения, между прочим, по отношению к секретным сотрудникам?

Герасимов: Особая инструкция? В каком году она была издана?

Председатель: Я могу сказать точно: в 1907 году, а потом переиздана, мажет быть, после вас, в 1914 году" [10, с. 9] (выделено мною. - Авт.).

Авторы статьи “Царская охранка и провокация" Ф.М. Лурье и З.И. Перегудова, цитируя второй диалог председателя, допускают “маленькую” неточность:

DOI (Article): https://doi.org/10.36486/np.2019.2.02

(c) Chysnikov Volodumyr, 2019 
вместо “я могу сказать точно...” указывают: “я не могу сказать точно...” [13, с. 63], ставя, таким образом, под сомнение 1907 год, а потом его же называют в качестве точной даты создания “столыпинской” инструкции (выделено мною. - Авт.).

Заметим, что В.К. Агафонов в своей работе еще в 1918 году датировал указанную инструкцию 1907 годом [16, с. 87]. В 70-х годах XX века в работах вузовских ученых системы МВД эта дата не вызывала никаких сомнений. Так, например, один из первых милицейских исследователей истории полиции Д.И. Шинджикашвили писал, что Инструкцию по организации внутреннего (агентурного) наблюдения, утвержденную министром внутренних дел П.А. Столыпиным, Департамент полиции разослал на места в 1907 году [18, с. 25-26]. Довольно обширные цитаты из этой инструкции, указывая 1907 год, приводили А. Атышев, Е. Глотов и В. Могилюк, ссылаясь на материалы Чрезвычайной следственной комиссии Временного правительства [19, с. 25-27]. Подобных примеров можно приводить достаточно много.

Заканчивая разбор указанной инструкции, отметим, что точная дата ее утверждения министром внутренних дел П.А. Столыпиным до настоящего времени остается не выясненной. Е.И. Щербакова - составитель весьма содержательного сборника документов по агентурной работе, датирует инструкцию “не ранее 10 февраля 1907 г.” [20, с. 95].

Нам представляется, что это было 9 февраля. Именно в этот день П.А. Столыпин подписал "Положение об охранных отделениях", а также инструкции по наружному (филерскому) и, надо полагать, по внутреннему (агентурному) наблюдению. Эта дата логически вытекает из ранее упомянутого сопроводительного письма от 10 февраля 1907 г., адресованного начальникам районных охранных отделений:

"Копия. Лично. Совершенно секретно.

Препровождая при сем "Положение о районных охранных отделениях", “Положение об охранных отделениях", утвержденные Господином Министром Внутренних Дел, шефом корпуса жандармов, 14 декабря 1906 г. и 9 февраля текущего года, "Инструкцию начальникам охранных отделений по организации наружного наблюдения", дополнение к ним, “Инструкщию по организащии и ведению внутреннего (агентурного) наблюдения”, Департамент полиции предлагает Вашему Высокоблагородию принять их к точному исполнению и руководству...” [13, с. 63] (выделено мною. - Авт.).

Теперь рассмотрим "Инструкцию по организации и ведению внутренней агентуры”, составленную при Московском охранном отделении, и вызывающую у исследователей множество вопросов.

Прежде всего возникает вопрос: сколько инструкций было составлено при Московском охранном отделении и когда именно?

В литературных источниках опубликовано две “московских" инструкции. Для удобства назовем первую - “жилинской” (по фамилии первого публикатора), а вторую - “заварзинской” (по фамилии составителя). Первая начинается словами: “І І. Общие указания. Главным и единственным основанием политического розыска является внутренняя, совершенно секретная и постоянная агентура". Впервые пространные выдержки из этой инструкции были опубликованы Б.В. Жилинским

DOI (Article): https://doi.org/10.36486/np.2019.2.02

(c) Chysnikov Volodumyr, 2019 
[21, с. 37-41], принимавшим участие в работе особой Комиссии по разбору материалов бывшего Московского охранного отделения. К сожалению, полный текст этой инструкции до сих пор не опубликован. Нам представляется, что “жилинская” инструкция является одним из вариантов “заварзинской”.

Заметим, что в начале 90-х годов ХХ ст. авторы-публицисты В.М. Жухрай [22] и П.А. Кошель [23], освещая содержание “жилинской” инструкции, безосновательно “дополнили” ее текстами из “заварзинской” инструкции и в таком комбинированном виде представили их в своих книгах, вводя тем самым читателей и некоторых ученых в заблуждение.

Не избежали подобного заблуждения и уважаемые профессора А.В. Федоров и А.В. Шахматов. Помещая в приложении (№ 6) извлечение из “жилинской” инструкции, они включили в нее и часть текста "заварзинской” инструкции (разд. III) [5, с. 253-264].

Вторая, “заварзинская” инструкция, существенно не отличалась от первой и начиналась словами: “І. Единственным, вполне надежным средством, обеспечивающим осведомленность розыскного органа, является внутренняя агентура..” [4, c. 2]. Извлечения из данной инструкции приводились в работах С.Б. Членова [24, с. 29-30] , В.К. Агафонова [16, с. 195-196], М.А. Цявловского [25, с. 18-19], а полностью ее текст был впервые опубликован 3.И. Перегудовой [4].

Как предполагают исследователи, эта инструкция была составлена начальником Московского охранного отделения П.П. Заварзиным на основании “столыпинской” инструкции (1907). Но, в отличии от нее, московская инструкция состояла из 5 разделов и давала больше конкретных советов по организации и ведению работы с секретными сотрудниками.

Отлитографированная в количестве 30-50 экземпляров, она (без согласования с Департаментом полиции) была разослана в жандармско-полицейские учреждения, подведомственные Московскому Районному охранному отделению. Однако, когда в начале марта 1911 г. Департамент полиции получил эту “самодеятельную” инструкцию, то потребовал немедленно изъять ее из обращения [16, с. 195]. Таким образом, в распоряжении жандармских офицеров она находилась непродолжительное время, и в качестве руководства по работе с агентурой они не смогли ею воспользоваться.

Что касается времени издания “московской” инструкции, то исследователями называются три даты: 1908 [26, с. 4], 1911 [6, с. 31], и 1914 [27, с. 344] годы. Нам представляется, что утверждение С.Н. Жарова является наиболее убедительным. В своей монографии он, в частности, пишет: “...Странным образом возникла проблема датировки Московской инструкции. 3.И. Перегудова, опубликовав ее в 1992 г., не указала дату создания. Но один из сохранившихся в Государственном архиве Российской Федерации экземпляров имеет на первой странице штамп, согласно которому инструкция зарегистрирована в секретном журнале входящих документов Особого отдела Департамента полиции 16 марта 1911 г. под № 982” [6, c. 32].

В декабре 1914 года Департаментом полиции был подготовлен проект новой "Инструкции Департамента полиции по организации и ведению внутреннего наблюдения в жандармских и розыскных учреждениях", которая обобщила

DOI (Article): https://doi.org/10.36486/np.2019.2.02

(c) Chysnikov Volodumyr, 2019 
положения “столыпинской” и “московской” инструкций, а также требования циркуляров Департамента полиции по работе с внутренней агентурой.

Следует сказать, что подготовка к изданию новых инструкций началась после проведения в Петербурге Первого съезда руководителей политического сыска (1912), на котором было принято решение “усовершенствовать имеющие инструкции, пересмотреть все циркуляры, издававшиеся Департаментом полиции с 1881 г. и действовавшие до сих пор” [8, с. 210-211]. Непосредственно составлением новых инструкций занимался подполковник В.Э. Энгбрехт, который находился в резерве при Петроградском ГЖУ. Кроме указанной инструкции по внутреннему наблюдению им были подготовлены “Инструкция Департамента полиции по организации и ведению наружного наблюдения в жандармских и розыскных учреждениях", а также “Свод правил по ведению политического розыска и отчетности по розыску в жандармских и розыскных учреждениях”. Весь подготовленный Энгбрехтом материал был объединен под общим заголовком "Наказ по ведению политического сыска” [8, с. 211-212].

Структурно инструкция по внутреннему наблюдению состояла из предисловия и пяти отделов: I-й. Общие положения (§§ 1-11); II-й. Приобретение агентуры (§§ 1-36); III-й. Ведение сотрудников (§§ 1-29); IV-й. Свидания и сношение (\$§ 1-32); V-й. Прикрытие агентуры и ликвидация (§§ 1-26), которые содержали, в общей сложности, 139 параграфов.

Отметим, что исследователям до недавнего времени были известны лишь фрагменты этой инструкции, опубликованные после падения самодержавия. Впервые ее полный текст был введен в научный оборот автором лишь в 2013 году [1, c. 40-98].

В современной научной литературе доминирует точка зрения, что департаментская инструкция 1914 года была “отпечатана и разослана руководителям всех подразделений, осуществляющим политический сыск” [13, с. 62; 27, с. 21 и др.]. В действительности, как свидетельствуют архивные документы и материалы, проект новой инструкции не был утвержден руководством Министерства внутренних дел, и его отправили на доработку. Об этом упоминал в своих воспоминаниях бывший товарищ (заместитель) министра внутренних дел и командир Отдельного корпуса жандармов генерал П.Г. Курлов, который, в частности, писал: “...мне не удалось изменить инструкции для политической агентуры, так как я был того мнения, что это потребует продолжительной и серьезной работы... Такого же мнения были, по-видимому, и все мои преемники” [28, с. 137].

В дальнейшем Департамент полиции поручил заниматься этим делом жандармскому генералу П.К. Попову, который к ноябрю 1916 г. подготовил "Наказ по ведению политического розыска”. В документе были обобщены все последние достижения опыта борьбы российских спецслужб с революционным движением, терроризмом и инакомыслием в империи, систематизированы все созданные ранее и новые нормативные акты (циркуляры), регулирующие систему разыскных органов, их полномочия, формы и методы оперативно-разыскной деятельности, ее финансирование, отчетность и т.д. Впервые этот документ был опубликован российским исследователем С.Н. Жаровым [6, с. 62-263].

DOI (Article): https://doi.org/10.36486/np.2019.2.02

(C) Chysnikov Volodumyr, 2019 
“Наказ” имел 15 отделов, которые делились на разделы и параграфы, а его общий объем составлял 268 листов машинописного текста. По сравнению с предыдущими инструкциями, этот нормативный акт существенно расширял круг организаций и лиц, подлежащих агентурному освещению. Фигурантами агентурных разработок, кроме участников революционного движения, становились военные части, сельская администрация, просветительские общества, средние и высшие учебные заведения, железнодорожные и почтовые служащие, масоны, сектанты и т.п. Новациями в документе были совершенно новые отделы: “Охрана лиц от покушений” (VIII) и "Работа розыскных учреждений по делам военного шпионажа” (IX). Руководство по работе с тайной агентурой находилась в VI-м отделе и называлось “Организация и ведение внутреннего наблюдения”.

VI отдел состоял из восьми разделов: І-й. Общие положення (§§ 1-10); IIй. Приобретение агентуры (§§ 1-17); III-й. Виды внутренней агентуры (§§ 1$20)$; IV-й. Завязка сношений с агентурой (§§ 1-12); V-й. Руководство агентурой (§§ 1-30); VI-й. Свидания и сношения с агентурой, ее выезды и командировки (§§ 1-33); VII-й. Прикрытие агентуры (\$§ 1-25); VIII-й. Разработка совершенно секретных документов ( $\S 1-7)$, которые содержали, в отличии от предыдущей инструкции, уже 162 параграфа, т.е на 23 параграфа больше.

Но и на этот раз новому проекту Департамента полиции по ведению политического сыска, в том числе и работы с агентурой, не суждено было стать советчиком для жандармских офицеров. Февральские события 1917 г. навсегда оставили его в истории последним, заключительным актом сыскной научной мысли, которая венчала собой длинный и всесторонний процесс правового регулирования борьбы русского царизма с революционным движением. И, как справедливо отметил С.М. Жаров, “Наказ” был первым (и последним в империи) кодексом политического розыска” [6, с. 4].

В заключение уместно будет сказать, что кроме “столыпинской” инструкции 1907 г. деятельность охранных структур по внутреннему (агентурному) наблюдению регламентировали также циркуляры Департамента полиции, которые развивали и разъясняли отдельные вопросы агентурной работы.

Таким образом, в начале XX века главным и единственным нормативноправовым актом по работе с секретной агентурой до конца существования Российской империи была "Инструкция по организации и ведению внутреннего (агентурного) наблюдения” (1907). Об этом также с несомненностью свидетельствует малоизвестный архивный документ - “Обзор циркуляров Департамента полиции, касающихся работы с агентурою”, впервые опубликованный автором [1, 163-184]. Вполне вероятно, что составителем этого документа был последний заведующий Особым отделом Департамента полиции И.П. Васильев, арестованный в марте 1917 г. Чрезвычайной следственной комиссией Временного правительства. Именно по ее поручению он составлял документы (обзоры) относительно некоторых аспектов деятельности Департамента полиции. Анализируя циркуляры Департамента полиции по работе с агентурой, автор “Обзора...” делает вывод: “...Приведенные выше примеры циркулярных распоряжений и разъяснений с несомненностью устанавливают, что вся деятельность Департамента за последние десять лет по руководству подчиненными местными учреждениями вдохновлялась взглядами

DOI (Article): https://doi.org/10.36486/np.2019.2.02

(c) Chysnikov Volodumyr, 2019 
и положениями Инструкции 1907 года по организации и ведению внутреннего наблюдения. Циркуляры развивали и закрепляли основные принципы этой Инструкции, но ничего существенно важного в дополнение к ее изменению не создавали ” [29].

\section{СПИСОК ИСПОЛЬЗОВАННЫХ ИСТОЧНИКОВ}

1. Таємна агентура Департаменту поліції МВС Російської імперії: нормативно-правові акти та проекти (1907-1916 рр.). Зб. док. і матеріалів: навч. посіб. авт.-упор.: В.М. Чисніков; упор.: П.Д. Біленчук, І.І. Котюк, С.Г. Лаптєв. К.: ВД “Докор”, 2013. 234 с.

2. Заварзин П.П. Работа тайной полиции. Париж. 1924.

3. Савченко А.В., Матвійчук В.В., Никифорчук Д.Й. та ін. Міжнародний досвід використання агентури правоохоронними органами держав Європи та США: навч. посібник. за заг. ред. Я.Ю. Кондратьєва. К.: КНТ, 2005. 88 с.

4. Тайны политического сыска: Инструкция о работе с секретными сотрудниками / публ. 3.И. Перегудовой. СПб., 1992. 15 с.

5. Федоров А.В., Шахматов А.В. Правовое регулирование содействия граждан органам, осуществляющим оперативно-разыскную деятельность. СПб. 2005. 338 с.

6. Жаров С.Н. Последняя попытка реформы политического розыска в Российской Империи: монография. Челябинск, 2007. 264 с.

7. Розенталь И.С. Провокатор. Роман Малиновский: судьба и время. М.: РОССПЭН, 1996. С. 16-17; Дресвянин С.П. Секретная война. Ростов н /Д: Феникс, 1998, С. 106-108; Галвазин С.Н. Охранные структуры Российской империи: формирование аппарата, анализ оперативной практики. М., 2001. С. 98-99; Воронцов С.А. Спецслужбы России: учеб. Ростов н/Д: Феникс, 2006. С. 181. $432 \mathrm{c}$.

8. Перегудова З.И. Политический сыск России (1880-1917 гг.). М.: РОССПЭН, 2000.

9. Смирнов М.П. и Шумилов А.Ю. ошибочно указывают, что эта инструкция состояла из 5 разделов. См.: Смирнов М.П., Шумилов А.Ю. Оперативно-разыскная деятельность в Российской империи в документах и комментариях (XVIII - февраль 1917 г.): монография. М.: Изд. дом Шумиловой И.И., 2010. С. 80.

10. Падение царского режима. Т. 3. М-Л, 1925.

11. Борисов А.В. Особый отдел империи. М., СПб., 2001.

12. Тарасюк I.B. Розшукова діяльність жандармсько-поліцейських органів Росії початку ХХ ст. Науковий вісник Укр. академії вн. справ (Київ). 1998. № 2.

13. Лурье Ф.М., Перегудова З.И. Царская охранка и провокация Из глубины времен. 1992. № 1.

14. Инструкция начальникам охранных отделений по организации наружного наблюдения была опубликована в 1908 г. Организационным бюро при ЦК партии эсеров.

15. Государственный архив Российской Федерации (ГАРФ). Ф. 1467. Оп. 1. Д. 38. Л.д. $85-91$.

16. Агафонов В.К. Заграничная охранка. Пг.,1918. Книга переиздана: Агафонов В.К. Парижские тайны царской охранки. М.: Изд-во “Русь”, 2004. 415 с.

17. Сватиков C.Г. Русский политический сыск за границей (по документам Парижского архива заграничной агентуры Департамента полиции). Ростов-на-Дону, 1918. 76 с.

18. Шинджикашвили Д.И. Сыскная полиция царской России в период империализма. Омск: ВШ МВД СССР, 1973.

19. Атышев А., Глотов Е., Могилюк В. Создание и деятельность III отделения и охранных отделений в России. Караганда: ВШ МВД СССР, 1973.

20. Агентурная работа политической полиции Российской империи. Сб. документов. 1880-1917 / сост. Е.И. Щербакова. М., 2006. 384 с.

21. Жилинский Б.B. Организация и жизнь охранного отделения во времена царской власти. M., 1918. 63 c.

DOI (Article): https://doi.org/10.36486/np.2019.2.02

(c) Chysnikov Volodumyr, 2019

Issue 2(4.4) 2019

http://naukaipravoohorona.com/ 

1991.

22. Жухрай В.M. Тайны царской охранки: авантюристы и провокаторы. М.: Политиздат,

23. История сыска в России. Кн. 1 / авт.-сост. Кошель А.П. Мн.: Литература, 1996.

24. Членов C. Охранные отделения в последние годы царствования Николая II. М.: Издво “Нива народная", 1917.

25. Большевики: документы по истории большевизма с 1903 по 1916 год бывшего Московского охранного отделения. 3-е изд. М.: Политиздат, 1990. Переиздание 1918 г., подготовленное к печати и предисловием М.А. Цявловским.

26. Самелюк М.А. Из истории лексики российских спецслужб - к происхождению и использованию термина “агент”. Оперативник (сыщик). 2009. № 2(19). С. 3-8.

27. Усенко В.Ф., Некрасов В.А., Мацюк В.Я. Використання конфіденційної допомоги громадянам у боротьбі зі злочинами: погляд сьогодення: монографія. К., 2007. 204 с.

28. Курлов П.Г. Конец русского царизма. М.-Пг.: Госиздательство, 1923. 295 с.

29. ГАРФ. Ф. 102. Оп. 314. Д. 628. Л.д. 23.

\section{REFERENCES}

1. Taiemna ahentura Departamentu politsii MVS Rosiiskoi imperii: normatyvno-pravovi akty ta proekty (1907-1916 rr.). "The Secret Agency of the Police Department of the Ministry of Internal Affairs of the Russian Empire: regulations and projects (1907-1916)". Coll. doc. and materials: teach. tool. auth-emphasis: V.M. Chisnikov; emphasis: PD Bilenchuk, I.I. Kotyuk, S.G. Laptev. K.: VD Dokor, 2013. 234 p. [in Ukrainian]. Russian].

2. Zavarzin P.P. (1924). Rabota taynoy politsii. "The work of the secret police". Paris [in

3. Savchenko A.V., Matviychuk V.V., Nykyforchuk D.Y. ta in. (2005) Mizhnarodnyi dosvid vykorystannia ahentury pravookhoronnymy orhanamy derzhav Yevropy ta SSHA. "International experience of using the agency by law enforcement agencies in Europe and the USA": study. manual. for the total. ed. Ya. Yu. Kondratiev. K.: CST. 88 p. [in Ukrainian].

4. Tayny politicheskogo syska: Instruktsiya o rabote s sekretnymi sotrudnikami. "Secrets of a Political Investigation: Instructions for Working with Secret Officers"/ publ. Z.I. Peregudova. SPb. 1992.15 p. [in Russian].

5. Fedorov A.V., Shakhmatov A.V. (2005). Pravovoye regulirovaniye sodeystviya grazhdan organam, osushchestvlyayushchim operativno-rozysknuyu deyatelnost. "Legal regulation of assistance to citizens bodies engaged in operational investigative activities. SPb. 338 p. [in Russian].

6. Zharov S.N. (2007). Poslednyaya popytka reformy politicheskogo rozyska v Rossiyskoy Imperii: monografiya. "The latest attempt to reform the political search in Russia Empires": a monograph. Chelyabinsk. 264 p. [in Russian].

7. Rozental I.S. (1996). Provokator. Roman Malinovskiy: sudba i vremya. "Provocateur. Roman Malinovsky: fate and time”. M.: ROSSPEN. P. 16-17; Dresvyanin S.P. (1998) Sekretnaya voyna. "Secret war". Rostov n/a: Phoenix, P. 106-108; Galvazin S.N. (2001). Okhrannye struktury Rossiyskoy imperii: formirovaniye apparata, analiz operativnoy praktiki. "Security structures of the Russian Empire: apparatus formation, analysis of operational practice”. M., P. 98-99; Vorontsov S.A. (2006) Spetssluzhby Rossii: ucheb. "Russian special services: textbook". Rostov n/a: Phoenix. 181 p. [in Russian].

8. Peregudova Z.I. (2000). Politicheskiy sysk Rossii (1880-1917 gg.). "Political Investigation of Russia (1880-1917)”. M.: ROSSPEN. 432 p. [in Russian].

9. Smirnov M.P., Shumilov A.Yu. (2010). oshibochno ukazyvayut, chto eta instruktsiya sostoyala iz 5 razdelov. Sm.: Smirnov M.P., Shumilov A.Yu. Operativno-razysknaya deyatelnost v Rossiyskoy imperii v dokumentakh i kommentariyakh (XVIII - fevral 1917 g.): monografiya. "Shumilov erroneously indicate that this instruction consisted of 5 sections. See: Smirnov M.P., Shumilov A.Yu. Investigative activities in the Russian Empire in documents and comments (XYIII - February 1917): monograph. M.: Publishing House Shumilova I.I. 80 p. [in Russian].

10. Padeniye tsarskogo rezhima. "The fall of the tsarist regime". T. 3. M-L, 1925 [in Russian]. Russian].

11. Borisov A.V. (2001). Osobyy otdel imperii. "Special department of the empire". M.-SPb [in

DOI (Article): https://doi.org/10.36486/np.2019.2.02

(c) Chysnikov Volodumyr, 2019 
12. Tarasiuk I.V. (1998). Rozshukova diialnist zhandarmsko-politseiskykh orhaniv Rosii pochatku XX st. "Investigative activity of the gendarme-police bodies of Russia beginning of the 20th century". Scientific Bulletin of Ukr. Academy of ex. Affairs (Kyiv). No. 2 [in Ukrainian].

13. Lurye F.M., Peregudova Z.I. (1992). Tsarskaya okhranka i provokatsiya Iz glubiny vremen. "Tsarist secret police and provocation From the depths times". No. 1 [in Russian].

14. Instruktsiya nachalnikam okhrannykh otdeleniy po organizatsii naruzhnogo nablyudeniya byla opublikovana v $1908 \mathrm{~g}$. "Instructions to the heads of security departments on the organization of outdoor the observation was published in 1908" by the Organizational Bureau of the Central Committee of the Socialist Revolutionary Party [in Russian].

15. Gosudarstvennyy arkhiv Rossiyskoy Federatsii (GARF). "The State Archive of the Russian Federation (GARF)”. F. 1467. Op. 1. D. 38. L.d. 85-91. [in Russian].

16. Agafonov V.K. (2004). Zagranichnaya okhranka. Pg., 1918. Kniga pereizdana: Agafonov V.K. Parizhskiye tayny tsarskoy okhranki. "Overseas security". PG., 1918. The book is reprinted: Agafonov V.K. "Parisian secrets of the royal secret police". M.: Publishing house "Rus". 415 p. [in Russian].

17. Svatikov S.G. (1918). Russkiy politicheskiy sysk za granitsey (po dokumentam Parizhskogo arkhiva zagranichnoy agentury Departamenta politsii). "Russian political investigation abroad" (according to the documents of the Paris archive of foreign agents of the Police Department). Rostov-on-Don. 76 p. [in Russian].

18. Shindzhikashvili D.I. (1973). Sysknaya politsiya tsarskoy Rossii v period imperializma. "The police of tsarist Russia during the period of imperialism". Omsk: Higher School of Internal Affairs of the USSR [in Russian].

19. Atyshev A., Glotov Ye., Mogiliuk V. (1973). Sozdaniye i deyatelnost III otdeleniya i okhrannykh otdeleniy v Rossii. "Creation and activity of the III department and security departments in Russia". Karaganda: Higher School of Internal Affairs of the USSR [in Russian].

20. Agenturnaya rabota politicheskoy politsii Rossiyskoy imperii. "Undercover work of the political police of the Russian Empire". Sat documents. 1880-1917. / comp.E.I. Shcherbakova. M., 2006. 338 p. [in Russian].

21. Zhilinskiy B.V. (1918). Organizatsiya i zhizn okhrannogo otdeleniya vo vremena tsarskoy vlasti. "The organization and life of the security department during the tsarist regime". M. 63 p. [in Russian].

22. Zhukhray V.M. (1991). Tayny tsarskoy okhranki: avantyuristy i provokatory. "Secrets of the royal secret police: adventurers and provocateurs. M.: Politizdat [in Russian].

23. Istoriya syska v Rossii. Kn. 1. "History of sysk in Russia". Book 1 / auto-comp. Koshel AP. Mn.: Literature, 1996 [in Russian].

24. Chlenov S. (1917). Okhrannyye otdeleniya v posledniye gody tsarstvovaniya Nikolaya II. "Security departments in the last years of the reign of Nikolay II". M.: Publishing House "Niva Narodnaia" [in Russian].

25. Bolsheviki: dokumenty po istorii bolshevizma s 1903 po 1916 god byvshego Moskovskogo okhrannogo otdeleniya. 3-ye izd. "Bolsheviks: documents on the history of Bolshevism from 1903 to 1916 of the former Moscow Security Division. 3rd ed”. M.: Politizdat, 1990. Reprint of 1918, prepared for publication and preface by M.A. Tsavlovsky [in Russian].

26. Sameliuk M.A. (2009). Iz istorii leksiki rossiyskikh spetssluzhb - k proiskhozhdeniu i ispolzovaniyu termina "agent". Operativnik (syshchik). From the history of vocabulary of Russian special services - to the origin and use of the term "agent". The operative (detective). No. 2 (19). P. 3-8 [in Russian].

27. Usenko V.F., Nekrasov V.A., Matsyuk V.Ya. (2007). Vykorystannia konfidentsialnoi dopomohy hromadianam u borotbi zi zlochynamy: pohliad sohodennia: monohrafiia. "The use of confidential assistance to citizens in the fight against crime: a view today": a monograph. K. 204 p. [In Ukrainian].

28. Kurlov P.G. (1923) Konets russkogo tsarizma. "The end of Russian tsarism”. M.-Pg.: State Publishing House.295 p. [in Russian].

29. GARF. F. 102. Op. 314. D. 628. L.d. 23 [in Russian].

DOI (Article): https://doi.org/10.36486/np.2019.2.02

(C) Chysnikov Volodumyr, 2019 


\section{Chysnikov Volodumyr, Doctor of Juridical Sciences, Docent, Chief Researcher, State Research Institute MIA Ukraine, Kyiv, Ukraine ORCID ID 0000-0003-2020-7298}

NORMATIVE AND LEGAL REGULATION OF INTERNAL (AGENTURIAL) SURVEILLANCE IN THE BODIES OF POLITICAL SEARCH OF THE RUSSIAN EMPIRE AT THE BEGINNING OF THE 20 ${ }^{\mathrm{TH}}$ CENTURY: SOME DISCUSSION ISSUES OF MODERN HISTORIOGRAPHY

The main method of activity of the political search of the Russian Empire at the beginning of the 20th century was internal (agenturial) surveillance. Having analyzed the historical, historical-legal and special literature, it mentions several gendarmeriepolice instructions, which regulated the work with agents in the field of political wanted list. First of all, this: "Instructions on the organization and conduct of internal (agenturial) surveillance" (1907), "Instructions on the organization and conduct of internal agency", drawn up at the Moscow Security Department (1911), "Instructions on the organization and conduct of internal surveillance in gendarmerie and search institutions" (1914) and "The order of political search" (1916). The full texts of all the above-mentioned instruments are currently published. And, as Professor Z.I. Perehudova, a well-known expert in political search, rightly points out, the issue of instructions "is not as simple as it may seem".

There is no consensus among researchers as to the number and timing of the publication of some instructions. Judging by the publications, there are only three "Moscow" instructions: 1908, 1911 and 1914, which is not complies with the reality. Scientific publications also often contain facts when the authors, speaking about the departmental instructions of 1907 and 1914, quote the "Moscow" instructions or conversely. The fate of the 1914 departmental instruction, the full text of which remained unpublished until recently, has not been fully clarified either.

Modern scientific literature is dominated by the opinion that the departmental instruction of 1914 was "printed and sent to the heads of all the units involved in the political investigation". In fact, as the archive documents and materials show, the draft of this instruction was not approved by the leadership of the Ministry of Internal Affairs and it was sent for further revision. This was mentioned in his memoirs by the former comrade (deputy) of the Minister of Internal Affairs and commander of the Separate Corps of Gendarmes, General P.H. Kurlov.

Having analyzed these legal acts, the author of the publication concludes that at the beginning of the 20th century the main and only legal act on work with secret agents until the end of the existence of the Russian Empire was the "Instruction on the organization and conduct of internal (agenturial) surveillance" (1907), and circulars

DOI (Article): https://doi.org/10.36486/np.2019.2.02

(C) Chysnikov Volodumyr, 2019 
DOI (Issue): https://doi.org/10.36486/np.2019.2

Issue 2(4-4) 2019

issued by the Police Department on these issues only developed and consolidated its basic principles.

Keywords: Police Department, instructions for internal surveillance (1907, 1911, 1914, 1916), political search, history of operative-search activity.

Отримано 06.06.2019 


\section{Греченко Володимир Анатолійович,} доктор історичних наук, професор, завідувач кафедри соціально-гуманітарних дисциплін факультету № 6 Харківського національного університету внутрішніх справ, заслужений працівник освіти України,

м. Харків, Україна

ORCID ID 0000-0002-6046-0178

Ярмиш Олександр Назарович,

доктор юридичних наук, професор,

головний науковий співробітник Інституту законодавства

Верховної Ради України, член-кореспондент Національної академії правових наук України, заслужений юрист України,

м. Київ, Україна

ORCID ID 0000-0002-4811-4520

\section{ОРГАНІЗАЦІЯ І ДІЯЛЬНІСТЬ МІЛІЩІї УКРАЇНСЬКОЇ РСР У 1951 р.}

У статті розглянуто організацію та основні напрями діяльності міліції в Україні у 1951 р., зважаючи на те, що проблема є малодослідженою. Автори використовували історичний принщип дослідження, вивчаючи прочеси, подї $і$ факти у хронологічній послідовності з урахуванням тогочасної суспільно-політичної ситуаціі. Новизна статті полягає в тому, що у ній вперше предметом дослідження стала історія мілічії у 1951 р., набули подальшого розвитку питання про досягнення та недоліки в ї̈ роботі у цей час, висвітлено основні аспекти діяльності міліціи щодо протидї злочинності.

Ключові слова: Україна, 1951 рік, мілічія, Міністерство державної безпеки, карний сиск, протидія злочинності

Актуальність теми дослідження визначається, передусім, низкою об’єктивних процесів, що відбуваються в українському суспільстві, корінне оновлення якого торкнулося всіх його сфер. Формування основ нової України, проведення соціально-економічних реформ, створення правової держави, впровадження демократизму в управлінні, зміцнення правопорядку і законності належать до найважливіших завдань сучасного періоду історії. Важливу роль у цих процесах відіграє забезпечення безпеки громадян та ефективна діяльність поліції. У цих умовах досвід минулого може бути корисним у протидії злочинності, за винятком, звичайно, негативних моментів, які не можуть бути використані в сьогоднішніх умовах, і сприятиме позбавленню від повторення помилок. Що стосується діяльності міліції щодо протидії злочинності в період після Другої світової війни, то криміногенна ситуація того часу мала певну подібність до сьогоднішньої, адже долати криміналітет у різних його іпостасях доводиться в умовах російської агресії та наявності значної кількості зброї на руках у населення, що викликає прямі аналогії з указаним історичним періодом. Тому накопичений досвід $є$, до

(c) Hrechenko Volodymyr, Yarmysh Oleksandr, 2019

DOI (Article): https://doi.org/10.36486/np.2019.2.03 
певної міри, повчальним для сьогодення. Слід зауважити, що 1951 рік не є переломним чи знаковим в історії України, як, скажімо, 1933, 1937 чи 1941 роки. Це був рік відносно звичайної, повсякденної діяльності міліції, проте саме цим він і цікавий. Безперечно, на події цього періоду істотно впливали попередні роки розвитку міліції, і ми не могли їх оминути.

Питання про організацію та діяльність міліції у повоєнні роки розглядали у своїх дисертаціях М.М. Лагоша [1], А.М. Васильєв [2], Р.Б. Герман [3], К.М. Ковальова [4], О.Ю. Жудік [5], А.П. Бескоровайний [6]. Проте їх дослідження охоплюють значно більший період, ніж той, який вивчаємо ми, тому періоду 1951 р. у них приділяється незначна увага. До того ж майже всі ці роботи, окрім дисертації М.М. Лагоші, побудовані на загальносоюзному матеріалі. Тому зазначену проблему можна вважати недостатньо дослідженою.

Мета нашої статті - дослідити основні аспекти діяльності міліції у 1951 р., вивчити стан іiї організаційної структури, вплив на неї попередніх реорганізацій цього правоохоронного органу, виявити досягнення та недоліки в її роботі.

Новизна статті полягає в тому, що у ній вперше вивчено основні напрями роботи міліції у конкретний історичний період - 1951 р., крім того, набули подальшого розвитку питання про головні завдання цього правоохоронного органу у вказаний період, а також доповнено питання про вплив структурних змін в організації міліції УРСР у попередні роки (1949-1950) на діяльність міліції у досліджуваний період.

Соціально-економічна ситуація в державі на початку 1950-х рр. зумовила об’єктивне висунення перед міліцією низки таких завдань: повсюдне поліпшення охорони громадського порядку, зміцнення патрульної служби, вдосконалення роботи карного розшуку, підвищення ролі дільничних уповноважених, розширення їх зв'язку з населенням, громадськістю; послідовна боротьба проти пияцтва i самогоноваріння; вдосконалення роботи з попередження правопорушень серед неповнолітніх у навчальних закладах, трудових колективах, за місцем проживання, боротьба з дитячою бездоглядністю; посилення боротьби з посяганнями на державну власність, повсюдне наведення суворого порядку в обліку і зберіганні матеріальних цінностей; боротьба з розкраданнями на транспорті, у будівництві, сфері торгівлі та громадського харчування, сільському господарстві; забезпечення своєчасного виявлення осіб, що ухиляються від суспільно корисної праці; поліпшення роботи з профілактики правопорушень і правового виховання населення [3].

17 жовтня 1949 року вся міліція УРСР з МВС СРСР була передана до Міністерства державної безпеки (МДБ). Такий крок відповідав зміцненню тоталітарного режиму в УРСР, посиленню централізації управління державою. У квітні цього ж року для посилення партійного контролю над органами міліції в міських і районних відділеннях міліції введені посади заступників начальників цих органів 3 політичної частини. Аналіз діяльності підрозділів міліції в цей період дає підстави для висновку, що перебування органів міліції в системі МДБ практично не спричинило принципових змін у структурі й основних напрямах роботи. Міліція як складова МВС, а згодом МДБ, виконувала властиві їй завдання, про які вже йшлося вище [1, с. 12]. У 1950 році карний розшук було перетворено у карний

DOI (Article): https://doi.org/10.36486/np.2019.2.03

(C) Hrechenko Volodymyr, Yarmysh Oleksandr, 2019 Issue 2(4.4) 2019 http://naukaipravoohorona.com/ 
“сиск”. Тоді ж скасовано зональний принцип керівництва місцевими органами розшуку як такий, що не виправдав себе, і введено лінійний (за видами злочинів) [7, арк. 110-115].

Слід відзначити, що перші повоєнні роки характеризувалися різким зростанням злочинності. Тенденція до стабілізації криміногенної ситуації почала виявлятися лише з покращенням соціально-економічної ситуації, відміною карткової системи та політикою зниження цін, що проводилася у 1947-1953рр. (ціни зменшилися у середньому в 13 разів). Так, починаючи з 1948 р., рівень злочинності впав приблизно на третину і продовжував у такому ж темпі знижуватися до 1952 р. [4]. У 1950 р. у державі було вчинено 525912 злочинів, 1951 р.- 503 794, 1952 р. - 474636 [8, с. 174]. Загальна кількість засуджених за кримінальні злочини зменшилася у 1947-1953 рр. на 570 тис. осіб [6, с. 12]. Проте серйозно ускладнювала протидію злочинності в досліджуваний період утопічна ідеологізована теза про те, що в соціалістичному суспільстві нібито немає соціальних коренів для існування злочинності, і це, по суті, слугувало приводом для перекладання провини за зростання рівня злочинності на міліцію.

Згідно з штатами органів міліції Міністерства державної безпеки Української РСР станом на 20 лютого 1951 р. структура республіканського апарату міліції була такою: відділ міліцейсъкої служби, на який покладалася охорона громадського порядку і громадської безпеки, проведення адміністративних заходів по здійсненню законів і розпоряджень центральних і місцевих органів влади, що стосуються питань охорони громадського порядку і громадської безпеки, які входять у функції міліції, а також ведення дізнання, бойова службова і фізична підготовка особового складу. Відділ карного сиску, який мав займатися боротьбою з кримінальною злочинністю - бандитизмом, розбоями, вбивствами, крадіжками й іншими кримінальними злочинами. Відділ по боротьбі з розкраданнями соціалістичної власності і спекулящією - вів роботу по боротьбі з розкраданнями соціалістичної власності, спекуляцією і фальшивомонетництвом. Слідчий відділ - займався проведенням слідства по відділах кримінального розшуку і ВБРСВ, здійснював керівництво слідчою роботою периферійних органів. Відділ розшуку - керував розшуком кримінальних злочинців, що втекли з в'язниць і ВТТ, осіб, що сховалися від суду і слідства, дезертирів із Радянської армії та з виробництва, осіб, що ухилялися від сплати аліментів, іноземців та осіб без громадянства, займався також агентурними установками і оперативним стеженням. Реєстраційно-обліковий відділ - мав досить широке поле діяльності. Він займався обліком агентури, агентурних розробок, слідчих справ і осіб, що проходили по них; обліком злочинців по категоріях, кличках, прийомах і методах вчинення злочинів; контролем за дотриманням термінів пред’явлення звинувачень, веденням слідства і дізнання, а також інших процесуальних норм; реєстрацією викраденої зброї і номерних предметів (автомобілів, мотоциклів, велосипедів, антикварних і художніх цінностей тощо); обліком речових доказів і знахідок, керував столами приводів і дактилоскопуванням злочинців; акумулював інформацію і займався статистикою. Існували також науково-технічний відділ, відділ з видачі дозволів на зброю та розмножувальні апарати, паспортний відділ, відділ віз та реєстраџї іноземщів, відділ актів громадянського стану, група з обліку природного руху населення, Державна

DOI (Article): https://doi.org/10.36486/np.2019.2.03

(c) Hrechenko Volodymyr, Yarmysh Oleksandr, 2019 Issue 2(44) 2019 http://naukaipravoohorona.com/ 
автомобільна інспекція, що здійснювала нагляд за технічним станом автотранспорту, витрачанням автоексплуатаційних матеріалів, за підготовкою шоферських кадрів, обліком і реєстрацією автомототранспорту, постачанням органів міліції номерними знаками, водійськими посвідченнями і технічними паспортами. Існували також відділ кадрів, особлива інспекція, секретаріат та політвідділ. Крім цього, до штату входило відділення негласного складу; група (агентурна установка); група (оперативне стеження); група (контроль і надання практичної допомоги в роботі відділень розвідки обласних і міських управлінь міліщіі) [9, с. 789-804].

Водночас (як і завжди) гострою була кадрова ситуація. Частково кадрову проблему керівництво держави спробувало розв'язати в 1950 р., прийнявши постанову про повернення до органів міліції всіх тих, хто служив у ній раніше. Проте цей кадровий захід не приніс відчутних результатів, у міліцію повернулася вкрай обмежена кількість співробітників, більшість з яких не були затребувані іншими державними органами і структурами. Одним із способів вирішення кадрових проблем в органах міліції став добір кадрів із вищих навчальних закладів країни. Цей захід був особливо важливим, враховуючи те, що кількість працівників міліції з вищою освітою складала нікчемний відсоток від їх загального числа, крім того, значна частина службовців не мала навіть середньої освіти, внаслідок чого освітній, інтелектуальний рівень працівників міліції в післявоєнні роки був украй низьким. Але поповнення кадрового потенціалу міліції освіченими кадрами відбувалося украй повільно і розтягнулося на довгі роки. Більшість із співробітників так само мали низький рівень освіти упродовж наступного десятиліття, але кадрове оновлення міліції розпочалося саме в ці роки [5].

Проблема щодо підвищення хоча б загальноосвітнього рівня особового складу міліції була настільки кричущою, що на навчання в загальноосвітніх школах у 1950-1951 рр. були зараховані всі працівники міліції України, які не мали 7річної чи 10-річної освіти, в кількості 17740 осіб. Але політвідділ ГУМ МДБ СРСР дійшов висновку, що це серйозна помилка, і за вказівкою його начальника, в школах загальноосвітньої підготовки були залишені 11292 працівники, які найбільш позитивно характеризувалися по службі та мали перспективу службового зростання. Проте в результаті неналежного контролю з боку окремих начальників міліції та політпрацівників, із цих шкіл було відраховано 2517 осіб, з них офіцерів - 1550 осіб, рядових і сержантів - 967. Результати екзаменів були такими: за початкову школу склали іспити 741 особа, за 7 клас - 1650 осіб, за 10 клас -265 осіб. Із тих, хто закінчив 10 клас, п'ятеро отримали золоті та срібні медалі [10, c. 301-302].

Комплектування органів міліції велося в основному з місцевого населення. У 1946 році українці становили 54,5 \% від усього особового складу міліції України, 1948 р. - 57,4 \%, у 1949 р. - 58,8 \%, а до 1953 р. вони становили 59,3 \% [1, с. 12].

Недостатній рівень освіти та загальної підготовки працівників міліції істотно впливав і на ефективність роботи цього правоохороного органу, що відзначалося в наказах керівництва МДБ, які вимагали “покращити" та “посилити” роботу. Так, 19 січня 1951 р. міністр державної безпеки СРСР В.А. Абакумов видав наказ про перебудову діяльності карного сиску і заходи щодо посилення боротьби 3 кримінальною злочинністю. У цьому наказі відзначалося, що “кримінальний

DOI (Article): https://doi.org/10.36486/np.2019.2.03

(c) Hrechenko Volodymyr, Yarmysh Oleksandr, 2019

Issue 2(44) 2019

http://naukaipravoohorona.com/ 
розшук, покликаний придушувати кримінальну злочинність, слабко справляється зі своїми обов’язками і перетворився на апарат переважно гласного, офіційного розслідування, малооперативний і такий, що потонув у паперах та не веде справжнього секретного сиску і кваліфікованої агентурної роботи”. Міністр вимагав "всебічно посилити агентурно-оперативну роботу кримінального розшуку, забезпечивши своєчасне попередження і розкриття кримінальних злочинів. Основний оперативний удар спрямувати на кримінальний рецидив, підбурювачів і натхненників злочинів, домагаючись одночасно ліквідації притулків злочинного елементу... Побудувати роботу апаратів кримінального сиску як в центрі, так і на місцях, суворо за видами кримінальних злочинів: а) бандитизм, розбої і вбивства; б) крадіжки державного, громадського і особистого майна; в) шахрайство, хуліганство й інші кримінальні злочини”. У наказі також містилися конкретні рекомендації щодо роботи сищиків: “сищики мають... знати звички і жаргон кримінальних злочинців, способи здійснення ними злочинів і місця збуту краденого; уміти оглядати місце злочину і вести стеження..., вивідувати все, що знадобиться для виконання доручених оперативних завдань; знати і досконало володіти науковотехнічними методами розкриття злочинів” та інше. У наказі вказувалося, що “сищики під час виконання своїх обов’язків стосовно працівників міліційної служби (інспектори, дільничні уповноважені та постові міліціонери) є старшими по службі. Приписувалося також створити в управліннях (відділах) міліційної служби відділи-відділення-групи дізнання, де вести справи про такі злочини, як дрібне хуліганство, нанесення побоїв, самоуправство, опір владі, образа її представників, порушення паспортного режиму, самовільний вихід з роботи, ухилення від військової служби, порушення правил по боротьбі з епідеміями, продаж і купівля квартир, крадіжка електроенергії, ушкодження майна і неплатіж аліментів [11, с. 769-777].

На виконання цього наказу Управління міліції м. Києва провело перевірку результатів роботи органів міліції цього міста щодо протидій злочинам у промисловій кооперації. У відповідній довідці, датованій 28 квітня 1951 р., відзначалося: "У результаті проведення оперативних і профілактичних заходів органи мілічї міста Києва за 1950 рік і перший квартал 1951 року по об'єктах промкооперачї порушили 39 кримінальних справ, за якими притягнуто до кримінальної відповідальності 93 особи, з них заарештовано 42 особи. Із загального числа притягнених (93 особи) за Указом Президії Верховної Ради СРСР від 4 червня 1947 року "Про кримінальну відповідальність за розкрадання державного і громадського майна" притягнуто 84 особи $і$ за спекулящію - 9 осіб. При цьому вилучено: грошей 69700 рублів, товарів та інших цінностей на суму - 70370 рублів. Крім того, накладений арешт на майно злочиниів на суму - 46900 рублів. Всього вилучено грошей, товарів й інших цінностей $i$ накладений арешт на майно злочинців на суму - 187470 рублів [12, с. 377].

Щоб зрозуміти специфіку діяльності міліції щодо протидії економічній злочинності у цей час, необхідно зупинитися на суті зазначеного Указу, а також іншого, оприлюдненого цього ж дня - “Про посилення охорони особистої власності громадян” [13]. Ці укази встановлювали таку ієрархію цінностей: державна власність, суспільна власність, особиста власність. Проте і відповідальність за

DOI (Article): https://doi.org/10.36486/np.2019.2.03

(c) Hrechenko Volodymyr, Yarmysh Oleksandr, 2019 
розкрадання державного та суспільного майна регламентувалася різними кримінально-правовими нормами. Відповідальність, згідно з відповідним Указом, за розкрадання державного, колгоспного, кооперативного та іншого суспільного майна не диференціювалася залежно від форми розкрадання. Крадіжка, присвоєння, розтрата та інше розкрадання державного майна каралося ув’язненням у виправно-трудовому таборі строком від 7 до 10 років із конфіскацією майна або без неї. Розкрадання колгоспного, кооперативного та іншого суспільного майна каралося ув'язненням у виправно-трудовому таборі строком від 5 до 8 років із конфіскацією майна або без неї. Отже, нерівність у кримінальному законодавстві за розкрадання державного та суспільного майна зберігалась. Таким чином, форми власності продовжували зберігати функцію критерію диференціації кримінальної відповідальності [14, с. 5-6]. Після прийняття вказаних вище указів середній термін ув'язнення за розкрадання у 1947-1952 рр. перевищив 8,5 років (у 19451946 pp. - 2 роки) [6, с. 12].

У результаті активної роботи міліції до 1953 р. були ліквідовані майже всі великі злодійсько-грабіжницькі зграї на території республіки. Якщо випадків бандитизму в Україні в 1951 р. було 167, то в 1952 р. всього зареєстровано 10 випадків пограбувань громадян [1, с. 14].

Покращилася робота і щодо протидії хуліганству. У доповідній записці міністра юстиції УРСР Д.Х. Панасюка "Про стан боротьби з хуліганськими проявами в республіці” від 5 жовтня 1951 р., де аналізувалася судова практика за перше півріччя 1951 р., відзначалося, що “більшість хуліганських проявів відзначаються в містах і робітничих селищах. Як показує вивчення справ, значна кількість - 30-35 \% усіх хуліганських проявів здійснюється в гуртожитках" [15, c. 321].

Внаслідок активних цілеспрямованих дій міліції громадський порядок у населених пунктах республіки з кожним роком поліпшувався. Так, якщо в 1949 р. було 2635 зухвалих хуліганських вчинків, то до 1951 р. їх кількість скоротилася до 1839, а в 1952 р. до 1571 випадків [1, с. 15].

Карний розшук та слідчі органи досягли у своїй роботі високих показників у розкритті найбільш небезпечних видів злочинів, який на кінець 1951 р. зріс порівняно $з$ першими повоєнними роками на $20 \%$. Зокрема, розкриття вбивств становило $88 \%$, пограбувань - 96,6 \%, проявів бандитизму - $100 \%$, розбоїв $73,9 \%$ [1, с. 14$]$.

Водночас у діяльності міліції були і певні недоліки, про що йшлося у відповідних документах МДБ УРСР. Так, у директиві МДБ УРСР про випадки провалу операцій під час затримання злочинців і загибелі особового складу міліції від 19 вересня 1951 р. вказувалося: “Незважаючи на низку директивних вказівок УМ МДБ УРСР, все ж продовжують мати місце провали операцій при затриманні злочинців і втрати особового складу органів міліції. Проведеними розслідуваннями встановлено, що це відбувається з таких причин: агентурна підготовка операцій не проводиться або проводиться украй незадавільно. Плани операцій ретельно не продумуються і складаються поспішно, конкретні завдання кожному учасникові операції не ставляться і взаємодії між ними не організовуються. Керівниками оперативних груп призначаються другорядні працівники, до їх складу виділяються

DOI (Article): https://doi.org/10.36486/np.2019.2.03

(C) Hrechenko Volodymyr, Yarmysh Oleksandr, 2019 Issue 2(44) 2019 http://naukaipravoohorona.com/ 
малодосвідчені та нездібні до рішучих дій люди. Озброєння злочинців, їх уміння користуватися зброєю і схильність до чинення озброєного опору не з'ясовуються. Маршрути, що забезпечують прихований підхід оперативних груп до місця операції, не вивчаються. Порушуються елементарні правила дотримання пильності особовим складом при затриманні окремих злочинців, проведенні обшуків, конвоюванні, виконанні інших оперативних доручень”. У директиві наводилося кілька прикладів таких невдалих операцій, зокрема щодо подій 12 лютого 1951 р. у Полтавській області. У цей день тут унаслідок проведеної поспішно, без достатньої підготовки, без попереднього вивчення місця проведення операції, без з'ясування озброєння злочинців, за відсутності належного інструктажу і розставляння оперативного складу, злочинцем у момент його затримання був убитий начальник Нехворощанського райвідділення міліції Полтавської області капітан Карчуков [16, c. 817-818].

Недоліки в організачії роботи щодо протидії кримінальній злочинності в Чернігівській та Сумській областях відзначалися в наказі Міністерства державної безпеки УРСР від 31 жовтня 1951 р. У ньому наголошувалося, що органи міліиіі цих областей незадовільно виконують накази МДБ СРСР по організацій боротьби з кримінальною злочинністю $і$ охороні громадського порядку. На територіі цих областей продовжує мати місце велика кількість убивств, грабежів та інших кримінальних проявів, а робота з їх розкриття ведеться погано, внаслідок чого в 1951 р. понад 20 \% кримінальних проявів залишилися нерозкритими. У серпнілистопаді 1951 р. на території цих областей вчинено низку озброєних пограбувань кас сільських рад. Заступник начальника Шосткинського міськвідділу мілічіі капітан мілічії Кириченко (виконував обов'язки начальника) особисто прачював погано, порушував дисципліну, допускав випивки, чим негативно впливав на підпорядкований склад, внаслідок чого агентурно-оперативна робота в міськвідділі мілічії знаходилася на межі розвалу. За розвал агентурно-оперативної роботи, пиячтво, порушення дисципліни $i$ погану боротьбу з кримінальною злочинністю, начальника Шосткинського міського відділу мілічї Сумської області капітана міліиї Кириченка було знято з роботи і понижено в посаді [17, с. 825-826].

Таким чином, упродовж досліджуваного періоду організаційна структура міліції змінювалася відповідно до завдань, що стояли перед державою, а також із урахуванням загальної тенденції мілітаризації органів внутрішніх справ в умовах посилення репресивно-каральної політики у 1949-1952 рр., що виявилося у черговому входженні міліції до складу Міністерства державної безпеки. Діяльність міліції відповідала вимогам охорони громадського порядку в той час і протидії злочинності в країні. Відбувся перехід від зонального на лінійний принцип боротьби зі злочинністю, що мало в цілому прогресивне значення. У 1951 р. вдалося продовжити тенденцію щодо загального зниження злочинності та кількості тяжких злочинів, зокрема підвищився відсоток їх розкриття. Водночас у діяльності міліції були істотні недоліки, на що впливало панування в державі сталінського тоталітарного режиму, а також недостатній професіоналізм частини співробітників та рівень їхньої освіти. 3 початку 1950-х років активізувалася робота з професійної підготовки особового складу органів міліції. Велика увага приділялася підвищенню загальноосвітнього рівня співробітників міліції, але остаточно це питання в

(c) Hrechenko Volodymyr, Yarmysh Oleksandr, 2019

DOI (Article): https://doi.org/10.36486/np.2019.2.03 
досліджуваний період не було повністю вирішене. Окреслена проблема потребує подальшого розроблення в плані розширення висвітлення саме діяльності міліції щодо протидії злочинності, а також розгляду зазначеного питання в контексті загальної історії правоохоронних органів у даний період.

\section{СПИСОК ВИКОРИСТАНИХ ДЖЕРЕЛ}

1. Лагоша М.М. Міліція України в 1945-1953 рр.: автореф. дис. ... канд. іст. наук.: 07.00.01. Донецьк, 2000. 24 с.

2. Васильев А.М. Охрана общественного порядка в СССР в послевоенный период: 19451953 гг.: автореф. дис. ... д-ра ист. наук: 07.00.02. М., 2009. 34 с.

3. Герман Р.Б. Организационно-правовые основы деятельности российской милиции по охране общественного порядка в борьбе с преступностью в годы Великой Отечественной войны и послевоенный период, 1941-1960 гг.: дис. ... канд. юрид. наук: 12.00.01. Ростов-на-Дону, 1999. 217 c. URL.: https://www.dissercat.com/content/organizatsionno-pravovye-osnovy-deyatelnostirossiiskoi-militsii-po-okhrane-obshchestvennogo (дата звернення: 10.04.2019).

4. Ковалева E.M. Организационно-правовые основы деятельности советской милиции по борьбе с преступностью в послевоенный период восстановления народного хозяйства и либерализации политического режима, социально-экономических реформ (1945-1960 гг.): дис. ... канд. юрид. наук: 12.00 .01 . M., 2002. 156 c. URL.: https://www.dissercat.com/content/organizatsionnopravovye-osnovy-deyatelnosti-sovetskoi-militsii-po-borbe-s-prestupnostyu-v-p (дата звернення: 10.04.2019).

5. Жудик А.Ю. Органы внутренних дел СССР в борьбе с преступностью (1945-1953 гг.): дис. ... канд. ист. наук: 07.00.02. М., 2006. 199 с. URL.:https://www.dissercat.com/content/organyvnutrennikh-del-sssr-v-borbe-s-prestupnostyu-1945-1953-gg (дата звернення: 10.04.2019).

6. Бескоровайный А.П. Борьба с преступностью и обеспечение общественного порядка в послевоенном СССР: 1945-1953 гг.: автореф. дис. ... канд. ист. наук: 07.00.02. М., 2008. 17 с.

7. Галузевий державний архів Міністерства внутрішніх справ України (ГДА МВС). Ф. 45. Оп. 5. Спр. 31. Арк. 110-115.

8. Ворожко В.П. Становлення та розвиток системи захисту державних секретів у радянській Україні (1919-1954 рр.): дис. ...канд. іст. наук: 07.00.01. Переяслав-Хмельницький, 2015. 232 с.

9. Вербенський М. Г., Ярмиш О. Н., Криволапчук В.О. та ін. Штаты органов милиции Министерства государственной безопасности Украинской ССР от 20 февраля 1951 г. Міністерство внутрішніх справ України: події, керівники, документи та матеріали (1917-2017 рр.): наук. вид. за заг. ред. А.Б. Авакова. К., 2016. Т. 5: НКВС-МВС радянської України в Другій світовій війні та в повоєнний період сталінської диктатури (22 червня 1941 р. -5 березня 1953 р.). Харків: Мачулін, 2016. 980 с.

10. Сокуренко В. В., Бандурка О. М., Греченко В. А. Підготовка охоронців правопорядку в Харкові: 100 років історії (1917-2017рр.): до 100-річчя подій Української революції: [монографія]. Харків: Золота миля, 2017. 496 с.

11. Вербенський М. Г., Ярмиш О. Н., Криволапчук В.О. та ін. Наказ міністра державної безпеки СРСР В.А. Абакумова про перебудову діяльності карного розшуку і заходи щодо посилення боротьби з кримінальною злочинністю від 19 січня 1951 р. Міністерство внутрішніх справ України: події, керівники, документи та матеріали (1917-2017 рр.): наук. вид. за заг. ред. А.Б. Авакова. К., 2016. Т. 5: НКВС-МВС радянської України в Другій світовій війні та в повоєнний період сталінської диктатури (22 червня 1941 р. - 5 березня 1953 р.). Харків: Мачулін, 2016. 980 c.

12. Михайленко П.П., Кондратьєв Я.Ю. Довідка про результати роботи органів міліції м. Києва по боротьбі зі злочинами в промисловій кооперації. Історія міліції України у документах і матеріалах: у 3 т. Київ: Генеза, 1997. Т. 3: 1946-1990. С. 397.

13. Об усилении охраны личной собственности граждан: указ Президиума Верховного Совета ССР от 4 июня 1947 года. Ведомости Верховного Совета СССР. 1947. № 19.

14. Анисимов В.Ф. Ответственность за хищения социалистической собственности по советскому уголовному законодательству. Вестник Югорского государственного университета. 2008. Вып. 4(11). С. 5-8.

(c) Hrechenko Volodymyr, Yarmysh Oleksandr, 2019

DOI (Article): https://doi.org/10.36486/np.2019.2.03

Issue 2(4.4) 2019

http://naukaipravoohorona.com/ 
15. Михайленко П.П., Кондратьєв Я.Ю. Доповідна записка міністра юстиції УРСР Д. Панасюка про стан боротьби з хуліганськими проявами у республіці від 5 жовтня 1951 р. Історія міліції України у документах і матеріалах: у 3 т. Київ: Генеза, 1997. Т. 3: 1946-1990. С. 321.

16. Вербенський М.Г., Ярмиш О.Н., Криволапчук В.О. та ін. Директива МДБ УРСР про випадки провалу операцій під час затримання злочинців і загибелі особового складу міліції від 19 вересня 1951 р. Міністерство внутрішніх справ України: події, керівники, документи та матеріали (1917-2017 рр.): наук. вид. за заг. ред. А.Б. Авакова. К., 2016. Т. 5: НКВС-МВС радянської України в Другій світовій війні та в повоєнний період сталінської диктатури (22 червня 1941 р. - 5 березня 1953 р.). Харків: Мачулін, 2016. 980 с.

17. Вербенський М.Г., Ярмии О.Н., Криволапчук В.О. та ін. Наказ Міністерства державної безпеки УРСР про недоліки в організації роботи по боротьбі з кримінальною злочинністю в Чернігівській і Сумській областях від 31 жовтня 1951 р. Міністерство внутрішніх справ України: події, керівники, документи та матеріали (1917-2017 рр.): наук. вид. за заг. ред. А.Б. Авакова. К., 2016. Т. 5: НКВС-МВС радянської України в Другій світовій війні та в повоєнний період сталінської диктатури (22 червня 1941 р. - 5 березня 1953 р.). Харків: Мачулін, 2016. 980 с.

\section{REFERENCES}

1. Lahosha M.M. (2000). Militsiia Ukrainy v 1945-1953 rr.: avtoreferat dys... kand.. ist. nauk. Spets. 07.00.01. "Militia of Ukraine in 1945-1953": the dissertation author's abstract of the candidate of Historical Sciences. Special. 07.00.01. Donetsk. 24 p. [in Ukrainian].

2. Vasilieyv A.M. (2009). Okhrana obshchestvennogo poryadka v SSSR v poslevoyennyy period: 1945-1953 gg. "Protection of Public Order in the USSR in the Post-War Period: 19451953": author. dis. Dr. Histor. Sciences. 07.00.02 M. 34 p. [in Russian].

3. German R.B. (1999). Organizatsionno-pravovye osnovy deyatelnosti rossiyskoy militsii po okhrane obshchestvennogo poryadka v borbe s prestupnostIu v gody Velikoy Otechestvennoy voyny i poslevoyennyy period, 1941-1960 gg. "Organizational and legal foundations of the activities of the Russian police for the protection of public order in the fight against crime during the Great Patriotic War and the postwar period, 1941-1960": dis. Cand. of Juridical Sciences. 12.00.01. Rostov-on-Don, 217 p. URL.: Https://www.dissercat.com/content/organizatsionno-pravovye-osnovy-deyatelnostirossiiskoi-militsii-po-okhrane-obshchestvennogo (date of application: 10.04.2019) [in Russian].

4. Kovaleva Ye.M. (2002). Organizatsionno-pravovye osnovy deyatelnosti Sovetskoy militsii po borbe s prestupnostiu v poslevoyennyy period vosstanovleniya narodnogo khozyaystva i liberalizatsii politicheskogo rezhima, sotsialno-ekonomicheskikh reform (1945-1960 gg.). "Organizational and legal bases of the activities of the Soviet police in the fight against crime in the post-war period of the restoration of the national economy and the liberalization of the political regime and socio-economic reforms (1945-1960)": dis. Cand. of Juridical Sciences. Specialist. 12.00.01. M., 156 p. URL.:https:/ /www.dissercat.com/content/organizatsionno-pravovye-osnovy-deyatelnosti-sovetskoi-militsii-po-borbes-prestupnostyu-v-p (date of application: 10.04.2019) [in Russian].

5. Zhudik A. Yu. (2006). Organy vnutrennikh del SSSR v borbe s prestupnostiu (1945-1953 gg.). "Organs of the USSR internal affairs in the fight against crime (1945-1953)": dis. Cand. of Hist. Sciences. Special. 07.00.02. M., 199 p. URL.: https://www.dissercat.com/content/organyvnutrennikh-del-sssr-v-borbe-s-prestupnostyu-1945-1953-gg] (date of application: 10.04.2019) [in Russian].

6. Beskorovainy A.P. (2008). Borba s prestupnostiu i obespecheniye obshchestvennogo poryadka v poslevoyennom SSSR: 1945-1953 gg. "Fighting crime and ensuring public order in the post-war USSR: 1945-1953": avtoref. dis. Cand. ist sciences. Special. 07.00.02.M.,17 p. [in Russian].

7. Haluzevyi derzhavnyi arkhiv Ministerstva vnutrishnikh sprav Ukrainy (HDA MVS). "The sectoral state archive of the Ministry of Internal Affairs of Ukraine (GDA of the Ministry of Internal Affairs)". C. 45. D 5. F. 31. L. 110-115 [in Ukrainian].

8. Vorozhko V.P. (2015). Stanovlennia ta rozvytok systemy zakhystu derzhavnykh sekretiv u radianskii Ukraini (1919-1954 rr.) "Formation and development of the system of protection of state secrets in Soviet Ukraine (1919-1954)": diss. Cand. Is. Sciences: special 07.00.01. PereyaslavKhmelnytskyi, 232 p. [in Ukrainian].

9. Verbenskyi M. H., Yarmysh O. N., Kryvolapchuk V.O. ta in. (2016) "Shtaty orhanov mylytsyy Mynysterstva hosudarstvennoy bezopasnosty Ukrainskoy SSR ot 20 fevralya 1951 h.” Ministerstvo vnutrishnikh sprav Ukrayiny: podiyi, kerivnyky, dokumenty ta materialy (1917-2017 rr.): nauk. vyd.

(c) Hrechenko Volodymyr, Yarmysh Oleksandr, 2019

DOI (Article): https://doi.org/10.36486/np.2019.2.03 
za zah. red. A.B. Avakova. K., 2016. T. 5: NKVS-MVS radianskoyi Ukrainy v Druhyi svitovyi viyni ta v povoiennyi period stalinskoi dyktatury (22 chervnia $1941 \mathrm{r}$. -5 bereznia $1953 \mathrm{r}$.). "States of the police of the Ministry of State Security of the Ukrainian SSR February 20, 1951" // Ministry of Internal Affairs of Ukraine: events, leaders, documents and materials (1917-2017 years): Sciences. kind. / avt. kol.: M.G. Verbensky, O.N. Yarmish, V.O. Kryvolapchuk et al.; for community edit A.B. Avakova. K., 2016. T. 5: NKVD-MIA of Soviet Ukraine in the Second World War and in the postwar period of the Stalinist dictatorship (June 22, 1941 - March 5, 1953). Kharkiv: Machulin. 980 p. [in Ukrainian].

10. Sokurenko V.V., Bandurka O.M., Grechenko V.A. (2017). Pidhotovka okhorontsiv pravoporiiadku v Kharkovi: 100 rokiv istorii (1917-2017 rr.): Do 100-richchia podii Ukrainskoi revoliutsii: [monohrafiia]. "Training of Law Enforcement Guards in Kharkov: 100 Years of History (1917-2017): The 100th Anniversary of the Events of the Ukrainian Revolution”: [monograph] Kharkov: Gold mile, 496 p. [in Ukrainian].

11. Verbenskyi M.H., Yarmysh O. N., Kryvolapchuk V.O. ta in. (2016). Nakaz ministra derzhavnoi bezpeky SRSR V.A. Abakumova pro perebudovu diIalnosti karnoho rozshuku i zakhody shchodo posylennia borotby z kryminalnoiu zlochynnistiu 19 sichnia $1951 \mathrm{r}$. Ministerstvo vnutrishnikh sprav Ukrainy: podii, kerivnyky, dokumenty ta materialy (1917-2017 rr.). "Order of the Minister of State Security of the USSR V.A. Abakumov on restructuring the activities of criminal prosecution and measures to strengthen the fight against criminal crime January 19, 1951. Ministry of Internal Affairs of Ukraine: events, leaders, documents and materials (1917-2017 years)": Sciences. kind. / avt.kol.: M.H. Verbensky, O.N. Yarmish, V.O. Kryvolapchuk et al.; for community edit A.B. Avakova. K., 2016. T. 5: NKVD-MIA of Soviet Ukraine in the Second World War and in the postwar period of the Stalinist dictatorship (June 22, 1941 - March 5, 1953). Kharkiv: Machulin, 2016. 980 s. 1941 r. -5 bereznya 1953 r.). Kharkiv: Machulin, 2016. 980 p. [in Ukrainian].

12. Mikhailenko P.P., Kondratiev Ya.Yu. (1997). Dovidka pro rezultaty roboty orhaniv militsii m.Kyieva po borotbi zi zlochynamy v promyslovii kooperatsii. Istoriia militsii Ukrainy u dokumentakh i materialakh. "The reference on the results of the work of the police in the city of Kyiv on combating crimes in industrial cooperation. History of the Militia of Ukraine in documents and materials: in 3 volumes". Kyiv: Geneza. T. 3: 1946-1990. 397 p. [in Ukrainian].

13. Ob usilenii okhrany lichnoy sobstvennosti grazhdan: ukaz Prezidiuma Verkhovnogo Soveta SSR ot 4 iyunya 1947 goda. Vedomosti Verkhovnogo Soveta SSSR. "On enhancing the protection of the personal property of citizens": Decree of the Presidium of the Supreme Soviet of the USSR on June 4, 1947. Vedomosti Supreme Soviet of the USSR. No. 19. [in Russian].

14. Anisimov V.F. (2008). Otvetstvennost za khishcheniya sotsialisticheskoy sobstvennosti po sovetskomu ugolovnomu zakonodatelstvu. "Responsibility for the plunder of socialist property under Soviet criminal law". Bulletin of the Ugra State University. Issue 4(11). P. 5-8. [in Russian].

15. Mikhailenko P.P., Kondratiev Ya.Yu. (1997). Dopovidna zapyska ministra yustytsii URSR D. Panasiuka pro stan borotby z khulihanskymy proiavamy u respublitsi 5 zhovtnia $1951 \mathrm{r}$. Istoriia militsii Ukrainy u dokumentakh i materialakh: u 3 t. Statement by the Minister of Justice of the Ukrainian SSR D. Panasyuk on the state of combating the hooligan manifestations in the republic on October 5, 1951. "History of the Militia of Ukraine in documents and materials": in 3 volumes / Kyiv: Genesis. T. 3: 1946-1990. 321 p. [in Ukrainian].

16. Verbenskyi M.H., Yarmish O.N., Kryvolapchuk V.O. (2016). Pro vypadky provalu operatsii pid chas zatrymannia zlochuntsiv I zahybeli osobovoho skladu militsii. "The Directive of the USSR of State Security on cases of failure of operations during the detention of criminals and the death of the militia personnel". September 19, 1951. Ministry of Internal Affairs of Ukraine: events, leaders, documents and materials (1917-2017). For community edit A.B. Avakova. K. T. 5: NKVD-MIA of Soviet Ukraine in the Second World War and in the postwar period of the Stalinist dictatorship (June 22, 1941 - March 5, 1953). Kharkiv: Machulin. 980 p. [in Ukrainian].

17. Verbenskyi M.H., Yarmysh O.N., Kryvolapchuk V.O. ta in. (2016). Nakaz Ministerstva derzhavnoi bezpeky URSR pro nedoliky v orhanizatsii roboty po borotbi z kryminalnoiu zlochynnistiu v Chernihivskyi i Sumskyi oblastiakh vid 31 zhovtnia $1951 \mathrm{r}$. Ministerstvo vnutrishnikh sprav Ukrainy: podii, kerivnyky, dokumenty ta materialy (1917-2017 rr.). "Order of the Ministry of State Security of the Ukrainian SSR on deficiencies in the organization of work on combating criminal crime in Chernihiv and Sumy regions October 31, 1951. Ministry of Internal Affairs of Ukraine: events, leaders, documents and materials (1917-2017): Sciences. kind. For community edit A.B. Avakova. K., 2016. T. 5: NKVD-MIA of Soviet Ukraine in the Second World War and in the

(c) Hrechenko Volodymyr, Yarmysh Oleksandr, 2019

DOI (Article): https://doi.org/10.36486/np.2019.2.03 
postwar period of the Stalinist dictatorship (June 22, 1941 - March 5, 1953). Kharkiv: Machulin. 980 p. [in Ukrainian].

UDK 343.9:[343.37+343.55](477)"1951 "

Hrechenko Volodymyr, Doctor of Historical Sciences, Full Professor, Head of the Department, Kharkiv National University of Internal Affairs, Kharkiv, Ukraine, ORCID ID 0000-0002-6046-0178, Yarmysh Oleksandr, Doctor of Juridical Sciences, Professor, Chief Researcher, Institute of Legislation of the Verkhovna Rada of Ukraine, Member of the Corresponding Member of the National Academy of Legal Sciences of Ukraine, Honored Lawyer of Ukraine, Kyiv, Ukraine, ORCID ID 0000-0002-4811-4520

\section{ORGANIZATION AND ACTIVITIES OF THE UKRAINIAN SSR MILITIA IN 1951}

The organizational structure and main directions of militia activity in Ukraine in 1951 are considered. The problem is poorly investigated. It shows how the structure of the militia was reorganized, the direction of its activity was considered the main, what functions were assigned to the criminal investigation. The authors argue that another subordination of the police to the Ministry of State Security was a typical manifestation of the strengthening of Stalin's totalitarian regime, but had little impact on the overall performance of the militia.

The authors draw upon the general scientific method, which requires the unity of historical and logical approach to the analyzed material. The authors strived to adhere to the historical principle by studying the processes, events and facts in chronological order, taking into account the socio-political situation of the time.

The novelty of the article lies in the fact that for the first time it studies the main directions of police work in this particular historical period - 1951, further development of the questions about the main tasks of this law enforcement agency at this time, and supplements the question about the influence of structural changes in the organization of police of the Ukrainian SSR in previous years (1949-1950) on the activities of the police in the period under study.

The authors note that the results of the conversion of the criminal investigation into a criminal "sysk" were insignificant. More effective was the abolition of the zonal principle of leadership of local search agencies and the introduction of linear (by type of crime). The structure of the governing bodies of the police in 1951 is highlighted, and it is indicated what functions each of the departments had.

(C) Hrechenko Volodymyr, Yarmysh Oleksandr, 2019

DOI (Article): https://doi.org/10.36486/np.2019.2.03 
DOI (Issue): https://doi.org/10.36486/np.2019.2 Issue 2(44) 2019

Considerable attention is paid to highlighting the main aspects of the work of the police to combat crime and the role of individual police units in this process, and certain achievements and shortcomings in this area of the work of the law enforcement agencies have been analysed. It is noted that during the period under review the general trend of decreasing crime in the state continued, and it was achieved due to the active work of the police in previous years. Shortcomings in police work were closely related to the personnel problem: there was a lack of employees with special education, and employees with higher education were very rare. Quite a significant percentage of police officers were Ukrainians. The leadership of the Ministry of State Security quite often analyzed the state of affairs in the police, pointed out the shortcomings and demanded that they be quickly addressed. In 1951, gangsterism and significant efforts to reduce manifestations of hooliganism and counteract economic crime were actually eliminated.

Keywords: Ukraine, 1951, militia, Ministry of State Security, criminal sysk, crime prevention.

Отримано 07.06.2019

(C) Hrechenko Volodymyr, Yarmysh Oleksandr, 2019

DOI (Article): https://doi.org/10.36486/np.2019.2.03 
УДК 342.8(477) “2019”

\author{
Вербенський Михайло Георгійович, \\ доктор юридичних наук, професор, \\ член Центральної виборчої комісії, \\ м. Київ, Україна \\ ORCID ID 0000-0001-6870-5427
}

\title{
ЗАБЕЗПЕЧЕННЯ СВОБОДИ ВОЛЕВИЯВЛЕННЯ ГРОМАДЯН ПІД ЧАС ВИБОРІВ ПРЕЗИДЕНТА УКРАЇНИ 2019 РОКУ: ПРАВОВИЙ АСПЕКТ
}

У статті висвітлено нормативно-правові засади забезпечення свободи волевиявлення громадян під час організащії та проведення виборчої кампанії $з$ виборів Президента України у 2019 рочі. Проаналізовано порядок забезпечення виборчого процесу центральними органами виконавчої влади, діяльність яких спрямовується та координується Кабінетом Міністрів України через Міністра внутрішніх справ та Національною гвардією Украӥни. Розкрито стан оперативного реагування, належного фіксування та розслідування діянь, пов'язаних із порушенням виборчого законодавства та проведенням передвиборної агітачії.

Ключові слова: вибори, вибориі, виборчий прочес, реалізачї̈ виборчих прав i свобод учасників виборчого процесу, порушення виборчого законодавства.

Одним із вищих характерних виявів влади та волі народу є вибори. За допомогою виборчого процесу громадянин може реалізувати право на управління державними справами, формування системи влади тощо. Визнання народу носієм суверенітету та джерелом влади обгрунтовує формування демократичної правової держави - України з проявом народовладдя та обумовлює актуальність дослідження питань щодо забезпечення виборчого процесу як форми функціонування безпосередньої демократії, комплексу превентивних заходів щодо запобігання можливим порушенням у волевиявленні громадян.

Упевненим кроком до ствердження демократії через вільне волевиявлення громадян стали вибори Президента України 2019 року, які відбулись за демократичними стандартами, закріпленими в Конституції України [1], та дотриманням законодавчих основ, які регламентують виборчий процес в Україні на засадах: 1) законності та заборони незаконного втручання будь-кого у цей процес; 2) політичного плюралізму та багатопартійності; 3) публічності та відкритості виборчого процесу; 4) рівності всіх кандидатів на пост Президента України; 5) рівності прав партій (блоків) - суб'єктів виборчого процесу; 6) свободи передвиборної агітації, рівних можливостей доступу кандидатів на пост Президента України до засобів масової інформації; 7) неупередженості органів виконавчої влади, органів місцевого самоврядування, підприємств, закладів, установ і організацій, їх керівників, інших

DOI (Article): https://doi.org/10.36486/np.2019.2.04

(c) Verbenskyi Mykhailo, 2019 
посадових і службових осіб до кандидатів на пост Президента України, партій (блоків) [2]. Ці принципи покликані забезпечити свободу волевиявлення виборців, відкритий і гласний характер виборів, здійснення судового й іншого захисту виборчих прав і свобод людини і громадянина, гарантії реалізації виборчих прав і свобод учасників виборчого процесу.

У науковій літературі під виборчим процесом розглядають систему врегульованих Конституцією й законами України основних послідовних процесуальних стадій (етапів) організації й проведення виборів у державі (В.Ф. Погорілко) [3, c. 157] та характеризують його як урегульовану правовими та іншими соціальними нормами діяльність органів, організацій, окремих громадян, їхніх колективів та груп з підготовки та проведення виборів у представницькі та інші виборні органи державної влади та місцевого самоврядування (В.В. Кравченко) [4, с. 120].

Як будь-яка комплексна система, виборчий процес має низку специфічних ознак, характерних для всіх правових форм. Насамперед, це процес, що здійснюється на підставі закону. Вибори є проявом демократії тільки в тому разі, коли проводяться у суворій відповідності до закону, гласно й неупереджено з боку органів публічної влади, коли вони є дійсно вільними й здійснюються на альтернативних засадах. В іншому випадку вони можуть перетворитися на свою протилежність і стати знаряддям узурпації влади, маніпулювання суспільною свідомістю [5, с. 197-198]. Ефективним виборчий процес як важлива складова демократичного формування влади може бути лише за умови проведення чесного і прозорого формування представницьких органів публічної влади, законодавчого закріплення та забезпечення принципів виборчого процесу, детального регулювання процедур щодо проведення виборів.

Для забезпечення законності у виборчому процесі, реалізації виборчого права, під час організації та проведення якого необхідно погоджене функціонування та взаємодія усіх гілок державної влади, органів місцевого самоврядування і громадських об'єднань. На сьогодні в Україні функціонує трирівнева система виборчих комісій: перший рівень - Центральна виборча комісія, другий рівень - окружні (територіальні) виборчі комісії; третій рівень - дільничні виборчі комісії. Наявна система виборчих комісій [5, с. 205] враховує територіальну організацію виборів (поділ державної території на виборчі округи та дільниці), забезпечує максимальне наближення пунктів для голосування до місця проживання виборців і спрямована на оперативне здійснення всіх стадій виборчого процесу в суворій відповідності з вимогами виборчого законодавства.

Центральна виборча комісія (ЦВК) є постійно діючим колегіальним державним органом. Вона очолює систему виборчих комісій, що утворюються під час організації та проведення загальнодержавних виборів, здійснює контроль за діяльністю та консультативно-методичне забезпечення виборчих комісій, що утворюються для проведення місцевих виборів та референдумів. Окружні виборчі комісії на президентських виборах формуються ЦВК за поданням кандидатів у Президенти України. Дільничні виборчі комісії формуються вищими окружними виборчими комісіями за поданням кандидатів у Президенти України.

Адміністрування виборчого процесу щодо обрання Президента України у 2019 р. здійснювалось Центральною виборчою комісією (ЦВК), 199 окружними

DOI (Article): https://doi.org/10.36486/np.2019.2.04

(C) Verbenskyi Mykhailo, 2019 
виборчими комісіями (ОВК) та майже 30 тис. дільничними виборчими комісіями (ДВК).

Водночас для того, щоб виборці мали змогу вільного волевиявлення та 3 метою забезпечення правопорядку під час організації та проведення виборчої кампанії з виборів Президента України, у 2019 році центральними органами виконавчої влади, діяльність яких спрямовується та координується Кабінетом Міністрів України через Міністра внутрішніх справ: Національною поліцією України, Державною міграційною службою України, Державної прикордонної служби України, Державною службою України з надзвичайних ситуацій, Державною службою з надзвичайних ситуацій та Національною гвардією України проведено широкомасштабні заходи. Завдяки злагодженій роботі та ефективній взаємодії правоохоронців грубих порушень та провокацій під час виборчого процесу не допущено. Підтвердженням цього є позитивна оцінка як іноземних спостерігачів, так і громадськості в цілому [6].

Окремо слід сказати про порушення у сфері адміністративної та кримінальної відповідальності, своєчасного та оперативного реагування, належного фіксування та розслідування правопорушень органами поліції та сприяння цьому з боку виборців та інших учасників виборчого процесу. До органів Національної поліції з початку виборчої кампанії з 31.12.2018 до 01.05.2019 (включно) надійшло 11226 заяв та повідомлень, пов'язаних із виборчим процесом.

Найбільше первинних відомостей про вчинення правопорушення або виникнення події впродовж виборів надійшло в період передвиборної агітації 3 31.12.2018 до 30.03.2019. За цей час їх зареєстровано близько половини - 5266 заяв та повідомлень.

У день виборів 31.03.2019 зафіксовано 2467 заяв та повідомлень, пов'язаних із виборчим процесом. Проте після дня голосування заяви і повідомлення продовжували надходити, і в період з 01.04.2019 до 21.04.2019 їх зареєстровано 1 886, а в день повторного голосування 21.04.2019 - 1 474, що значно менше, ніж у день виборів 31.03.2019.

У період з 22.04.2019 до 30.04.2019, після дня повторного голосування надійшла, умовно кажучи, незначна кількість - 133 заяви та повідомлення.

Територіально найбільшу кількість заяв і повідомлень зареєстровано в місті Києві - 1492 та Дніпропетровській області - 1 232. В інших областях показник зареєстрованих заяв та повідомлень не перевищував тисячі, зокрема: в Донецькій - 950, Одеській - 778, Харківській - 562, Київській - 546, Полтавській - 520, Вінницькій - 501, Чернігівській - 436, Миколаївській - 416, в інших областях, Луганській, Волинській, Кіровоградській, Тернопільській, Херсонській, Запорізькій, Черкаській, Рівненській, Львівській, Житомирській, Закарпатській, Чернівецькій, Івано-Франківській, Хмельницькій від 400 до 130.

Переважна більшість зазначених фактів пов'язана з проведенням незаконної агітації. Загалом таких фактів виявлено 3 475, з них у Києві - 540, в областях: Дніпропетровській - 347, Вінницькій - 216, Полтавській - 191, Харківській 167, Волинській - 165, Донецькій - 159, Одеській - 151, Київській - 139, Кіровоградській - 137, Тернопільській - 134, Миколаївській - 133, Херсонсь-

DOI (Article): https://doi.org/10.36486/np.2019.2.04

(C) Verbenskyi Mykhailo, 2019 
кій - 123, Сумській - 112, Черкаській - 108, Луганській - 104, Запорізькій 103, в інших областях менше ста.

Серед інших найбільш поширених правопорушень зафіксовано: підкуп виборців - 973 випадків, відсутність у списках виборців - 511, хуліганство - 397, перешкоджання здійсненню виборчого права - 355, фотографування виборчого бюлетеня - 300, фальсифікація виборчих документів - 299.

Не набули масового характеру випадки збору персональних даних - 181, пошкодження майна - 109, пошкодження виборчого бюлетеня - 67, погрози фізичної розправи - 59, перешкоджання роботі виборчої комісії - 57, незаконне використання виборчого бюлетеня - 55, оформлення запрошення на вибори померлого - 49, відсутність виборчої документації - 39, крадіжки - 30, винесення бюлетенів за межі виборчої дільниці - 28, тілесні ушкодження - 26, порушення таємниці голосування - 22, службове підроблення -21 , порушення виборчого процесу - 20, неправильне опломбування виборчих скриньок -19 , незаконне використання адмінресурсу - 15 тощо.

Мали місце неправдиві повідомлення про замінування, яких надійшло 17. Найбільше таких повідомлень зафіксовано в Дніпропетровській області - 11. Як повідомили в Національній поліції, здебільшого така інформація надходила 3 території Російської Федерації. Крім того, зафіксовано 3 неправдивих повідомлення про замінування на Донеччині, та по 2 в Чернігівській області і в Києві [7].

Основними суб'єктами, від яких до органів поліції надійшло 8026 заяв, повідомлень про кримінальні, адміністративні правопорушення або події, стали громадяни, іншими заявниками були поліцейські (подання рапортів) - 1471, спостерігачі громадської мережі “Опора” - 677, інші громадські організації 511, члени окружних виборчих комісій (ОВК)/дільничних виборчих комісій (ДВК) - 460, міжнародні/офіційні спостерігачі - 85, представники політичних партій - 60, народні депутати - 29, кандидати на посаду Президента - 14, суди 10 тощо.

В основу протидії правопорушенням, пов’язаним із виборами, покладено забезпечення попередження таких правопорушень. Основними попереджувальними засобами визначено: а) роз'яснення вимог законодавства і попередження про відповідальність за порушення; б) швидке реагування на повідомлення про порушення, невідкладне вжиття всіх передбачених законодавством заходів для припинення протиправних дій та забезпечення невідворотності покарання правопорушника.

3 метою оперативного реагування за вказаними фактами правоохоронцями здійснювались скоординовані дії чергових служб, нарядів патрульної поліції, груп реагування патрульної поліції, слідчо-оперативних груп та інших нарядів, спрямовані на організацію невідкладного прибуття до заявника або на вказане місце події з метою припинення порушення виборчого законодавства, установлення особи та затримання ймовірного правопорушника, збереження слідів злочину, а також надання допомоги потерпілим особам. У зв’язку з посиленим варіантом несення служби кількість поліцейських нарядів було збільшено. Крім того, 3 21 березня 2019 р. для забезпечення громадського порядку, охорони виборчих дільниць та виборчої документації під час виборов були задіяні всі підрозділи

DOI (Article): https://doi.org/10.36486/np.2019.2.04

(C) Verbenskyi Mykhailo, 2019 
Національної поліції. Поліцейські спільно зі співробітниками Державної служби 3 надзвичайних ситуацій забезпечували обстеження технічного стану дільниць на відповідність нормам протипожежної безпеки, перевірку надійності сейфів, у яких мала зберігатися документація (бланкова продукція) до виборів.

Із зазначеної кількості повідомлень Національною поліцією про злочини і події 433 віднесено до кримінальних правопорушень, з яких пов'язаних із порушенням виборчого законодавства - 255. 3 них за видами: ст. 160 КК України "Підкуп виборців" - 90, ст. 158-1 "Незаконне використання виборчого бюлетеня" - 64, ст. 157 "Перешкоджання здійсненню виборчого права" - 53, ст. 158 "Надання неправдивих відомостей до органу ведення Державного реєстру виборців або фальсифікація виборчих документів, документів референдуму, підсумків голосування або відомостей Державного реєстру виборців” - 25, ст. 159 “Порушення таємниці голосування" - 13, ст. 159-1 “Порушення порядку фінансування політичної партії, передвиборної агітації, агітації з всеукраїнського або місцевого референдуму" - 7, ст. 158-2 "Незаконне знищення виборчої документації або документів референдуму" - 3 .

До опосередковано пов'язаних із проведенням виборчої кампанії віднесено 178 кримінальних проваджень, серед них за ст. 296 КК України "Хуліганство”, ст. 185 “Крадіжка”, ст. 358 “Підроблення документів, печаток, штампів та бланків, збут чи використання підроблених документів, печаток, штампів”, ст. 259 “Завідомо неправдиве повідомлення про загрозу безпеці громадян, знищення чи пошкодження об'єктів власності”, ст. 192 “Заподіяння майнової шкоди шляхом обману або зловживання довірою”, ст. 366 “Службове підроблення”, ст. 357 “Викрадення, привласнення, вимагання документів, штампів, печаток, заволодіння ними шляхом шахрайства чи зловживання службовим становищем або їх пошкодження” та ст. 345 “Погроза або насильство щодо працівника правоохоронного органу”.

Найбільшу кількість кримінальних проваджень Національною поліцією відкрито в таких областях: Житомирській - 74, Донецький - 56, Дніпропетровській - 38, Чернігівській -35 .

Станом на початок травня 2019 р. у провадженні слідчих перебуває 132 кримінальні справи.

Із загальної кількості кримінальних проваджень 50 особам повідомлено про підозру за 42 кримінальними провадженнями.

За результатами розгляду відкритих кримінальних проваджень, до суду вже направлено 31 кримінальне провадження. Проти попередніх років результати роботи слідчих підрозділів Національної поліції є більш ефективними. Так, моніторинг діяльності правоохоронних органів та судових інституцій України, який у 2015 р. провела Громадянська мережа ОПОРА спільно з Міжнародною фундацією виборчих систем (IFES), засвідчував, що до суду дійшло лише 13 кримінальних проваджень із 291 розпочатого провадження [8].

За підслідністю до Служби безпеки України та Державного бюро розслідувань передано 12 кримінальних проваджень: ст. 112 - 1, ст. 157 - 1, ст. 361 - 1, ст. 258 3, ст. 365 - 3, ст. 367 - 1, ст. 368 - 1, ст. 129 - 1.

DOI (Article): https://doi.org/10.36486/np.2019.2.04

(C) Verbenskyi Mykhailo, 2019 
Також заслуговує на увагу, що за період виборчої кампанії з 31.12.2018 до 01.05.2019 складено 915 протоколів про вчинення адміністративних правопорушень. Найбільшу кількість складено у період передвиборної агітації з 31.12.2018 до 30.03.2019 - 690. У день виборів 31.03.2019 - 33 адміністративні протоколи, а в день повторного голосування 21.04.2019 - 55. Після дня голосування в період 3 01.04.2019 до 21.04.2019 - 99 адміністративних протоколів, а після дня повторного голосування - 37. На сьогодні 646 адміністративних протоколів направлено до суду, за 268 прийнято рішення та накладено штрафи у 159 випадках.

Водночас за 1456 фактами проводиться перевірка згідно із Законом України “Про звернення громадян”, за 8285 матеріалами факти правопорушення не знайшли підтвердження.

Зазначене вище свідчить про оперативність реагування та компетентність правоохоронців у виявленні, фіксації порушень виборчого законодавства. Загалом президентські вибори 2019 р. проведені демократично і без резонансних подій, а грубих порушень і провокацій під час виборчого процесу не допущено взагалі.

Органи адміністрування виборчого процесу здійснювали свою діяльність переважно неупереджено та дотримувались вимог законодавства. Випадки порушень у їх діяльності, хоча і мали місце, не набули системного характеру.

Зафіксовані порушення суттєво не відрізнялися від практики минулих Президентських виборів. Так, у 2014 р. найбільш системним було недотримання правил передвиборної агітації та перешкоджання виборчому процесу, а у 2019 р. незаконна агітація та підкуп виборців, що є наслідком зловживань з боку кандидатів [9].

Підтримання постійної готовності сил і засобів до реагування на правопорушення або події на етапі підготовки та проведення виборів, забезпечення безпеки громадян, членів виборчої комісії, представників ЗМІ, спостерігачів за виборчим процесом у день проведення виборів залишається одним з основних завдань правоохоронних органів правопорядку і безпеки системи МВС. Охорона виборчого процесу під час проведення парламентських виборів зобов'язує правоохоронців до поглибленого, системного навчання з питань виборчого законодавства, захисту виборчих прав, реагування на порушення тощо, оскільки ефективна діяльність органів правопорядку є гарантом забезпечення законності цього процесу.

Виборчий процес під час виборів Президента України у 2019 р. визначається проявом високої громадянської правової культури українців, а також активною правоохоронною позицією органів правопорядку в контексті забезпечення рівного права для кожного громадянина обирати і бути обраним.

Досвід роботи, отриманий правоохоронними органами, зокрема Національною поліцією, під час виборчої кампанії, потребує подальшого дослідження і застосування щодо створення сталої системи захисту виборчих прав громадян від протиправних посягань, а також удосконалення діяльності з попередження злочинів і правопорушень, які посягають на пов’язані з виборами правовідносини.

\section{СПИСОК ВИКОРИСТАНИХ ДЖЕРЕЛ}

1. Конституція України 28.06.1996 № 254к/96-BP. URL:https://zakon.rada.gov.ua/laws/ show $/ 254 \% \mathrm{D} 0 \% \mathrm{BA} / 96-\% \mathrm{D} 0 \% \mathrm{~B} 2 \% \mathrm{D} 1 \% 80$ (дата звернення: 01.05.2019).

DOI (Article): https://doi.org/10.36486/np.2019.2.04

(C) Verbenskyi Mykhailo, 2019 
2. Про вибори Президента України: Закон України від 05.03.1999 № 474-XIV, (Відомості Верховної Ради України (BВP), 1999, № 14, ст. 81) № 474-XIV. URL: https://zakon.rada.gov.ua/ laws/show/474-14 (дата звернення: 01.05.2019).

3. Погорілко В.Ф., Федоренко В.Л. Конституційне право України: підручник. К.: Наук, думка; Прецедент, 2006. 338 с.

4. Кравченко В.В. Конституційне право України: навч. посіб. К.: Атіка, 2000. 320 с.

5. Серьогін B.О. Конституційне право України: навч. посіб. Харківський нац. ун-т внутр. справ. Харків: Вид-во ХНУВС, 2010. 368 с.

6. Національна поліція розпочинає розрахунок сил і засобів для роботи під час другого туру президентських виборів. URL: https://www.ukrinform.ua/rubric-elections/2672723-policiapocinae-gotuvatisa-do-drugogo-turu-viboriv.html (дата звернення: 01.05.2019).

7. Через порушення на виборах почато 31 провадження - поліція: Українська правда 31 березня 2019 року. URL: https:// www.pravda.com.ua/news/2019/03/31/7210887/ (дата звернення: 01.05.2019).

8. Підсумковий звіт за результатами громадського спостереження ОПОРИ під час позачергових виборів Президента України 2014 року. URL:https:/ www.oporaua.org/report/vybory/ vybory-prezidenta/vybory-prezidenta-2014/5802-pidsumkovyj-zvit-za-rezultatamy-gromadskogosposterezhennja-opory-pid-chas-pozachergovyh-vyboriv-prezydenta-ukrajiny-2014-rok (дата звернення: 01.05.2019).

9. Понад 60 поліцейських Київщини взяли участь у тренінгу ОПОРИ щодо реагування на порушення виборчого законодавства. URL: https://www.oporaua.org/news/vybory/vyboryprezidenta/vybory-prezidenta-2019/16631-ponad-60-politseiskikh-kiyivshchini-vziali-uchast-u-treninguopori-shchodo-reaguvannia-na-porushennia-viborchogo-zakonodavstva (дата звернення: 01.05.2019)/

\section{REFERENCERS}

1. Konstytutsiia Ukrainy 28.06.1996 № 254k/96-VR. “The Constitution of Ukraine 28.06.1996 No. 254k / 96-VR". URL:https://zakon.rada.gov.ua/laws/show/254\%D0\%BA/96-\%D0\%B2\%D1\%80 (date of application: 01.05.2019) [in Ukrainian].

2. Pro vybory Prezydenta Ukrainy. "On the election of the President of Ukraine": Law of Ukraine of 05.03.1999 No. 474-XIV, (Vidomosti Verkhovnoi Rady Ukrainy, 1999, No. 14, Art. 81) No. 474-XIV URL: https: //zakon.rada. gov.ua/laws/show/474-14 (date of application: 01.05.2019) [in Ukrainian].

3. Pohorilko V.F., Fedorenko V.L. (2006) Konstytutsiine pravo Ukrainy: pidruchnyk. "Constitutional Law of Ukraine”: a textbook. K.: Naukova dumka; Precedent. 338 p. [in Ukrainian].

4. Kravchenko V.V. (2000) Konstytutsiine pravo Ukrainy: navch. posib. "Constitutional Law of Ukraine": Tutorial. K.: Attica. 320 p. [in Ukrainian].

5. Serohin V.O. (2010) Konstytutsiine pravo Ukrainy: navch. posib. "Constitutional Law of Ukraine": Tutorial. Kharkov National University of Internal Affairs MIA of Ukraine. Kharkiv: publ., KhNUVS. 368 p. [in Ukrainian].

6. Natsionalna politsiia rozpochynaie rozrakhunok syl i zasobiv dlia roboty pid chas druhoho turu prezydentskykh vyboriv. "National police begin calculating forces and resources to work during the second round of presidential elections". URL: https://www.ukrinform.ua/rubric-elections/2672723policia-pocinae-gotuvatisa-do-drugogo-turu-viboriv.html (date of application: 01.05.2019) [in Ukrainian].

7. Cherez porushennia na vyborakh pochato 31 provadzhennia - politsiia: Ukrainska pravda 31 bereznia 2019 roku. "The police opened 31 cases for election violations": Ukrainskaia Pravda on 31 March 2019. URL: https: // www.pravda.com.ua/news/2019/03/31/7210887/ (date of application: 01.05.2019) [in Ukrainian].

8. Pidsumkovyi zvit za rezultatamy hromadskoho sposterezhennia OPORY pid chas pozacherhovykh vyboriv Prezydenta Ukrainy 2014 roku. "Final report on the results of public observation of the OPORA during the early presidential elections in Ukraine 2014”. URL:https:// www.oporaua.org/report/vybory/vybory-prezidenta/vybory-prezidenta-2014/5802-pidsumkovyj-zvitza-rezultatamy-gromadskogo-sposterezhennja-opory-pid-chas-pozachergovyh-vyboriv-prezydentaukrajiny-2014-rok (date of application: 01.05.2019) [in Ukrainian].

9. Ponad 60 politseyskykh Kyivshchyny vzialy uchast u treninhu OPORY shchodo reahuvannia na porushennia vyborchoho zakonodavstva. "More than 60 police officers from Kyiv region took part

DOI (Article): https://doi.org/10.36486/np.2019.2.04

(C) Verbenskyi Mykhailo, 2019 Issue 2(44) 2019 http://naukaipravoohorona.com/ 
in the training of OPORA to respond to violations of electoral legislation”. URL: https:// www.oporaua.org/news/vybory/vybory-prezidenta/vybory-prezidenta-2019/16631-ponad-60politseiskikh-kiyivshchini-vziali-uchast-u-treningu-opori-shchodo-reaguvannia-na-porushenniaviborchogo-zakonodavstva (date of application: 01.05.2019) [in Ukrainian].

UDC 342.8(477) “2019”

Verbenskyi Mykhailo, Doctor of Juridical Sciences, Professor, Member of the Central Election Comission, Kyiv, Ukraine ORCID ID 0000-0001-6870-5427

\section{ENSURING THE FREEDOM OF EXPRESSION OF THE WILL OF CITIZENS DURING THE PRESIDENTIAL ELECTIONS IN UKRAINE 2019: THE LEGAL ASPECT}

Elections are one of the highest characteristic manifestations of power and the will of the people. Through the electoral process, a citizen can implement the right to manage public affairs, form a system of power, etc. The recognition of the people as a bearer of sovereignty and a source of power has become the basis for the formation of Ukraine as a democratic State based on the rule of law, with the manifestation of people's power, and makes it essential to study the issues of ensuring the electoral process as a form of functioning of direct democracy and a set of preventive measures to prevent possible violations of the will of citizens. Accordingly, the article highlights the regulatory framework for ensuring freedom of expression of the will of citizens during the organization and conduct of the election campaign for the Presidential elections in Ukraine in 2019. The procedure for ensuring the electoral process by the central executive authorities, whose activities are directed and coordinated by the Cabinet of Ministers of Ukraine through the Minister of Internal Affairs and the National Guard of Ukraine, has been analyzed. The current state of prompt response, proper accounting and investigation of actions related to the violation of the electoral legislation and the conduct of the election campaign are disclosed.

Based on the results of consideration of these issues, conclusions were drawn regarding the promptness of the response and the competence of law enforcement agencies in identifying and recording violations of electoral legislation. The holding of the 2019 presidential elections was generally recognized as democratic and without high-profile events, without gross violations and provocations during the electoral process. The election administration conducted its activities in a predominantly impartial manner and adhered to legal requirements. Cases of irregularities in their activities, even though they occurred, have not become systematic.

The electoral process during the presidential elections in 2019 was determined by the expressed manifestation of a high civic legal culture of Ukrainians, as well as an active law enforcement position of the policing in the context of ensuring equal rights for every citizen to elect and be elected.

DOI (Article): https://doi.org/10.36486/np.2019.2.04

(C) Verbenskyi Mykhailo, 2019 
DOI (Issue): https://doi.org/10.36486/np.2019.2

Issue 2(44) 2019

The experience gained by the law enforcement bodies, in particular the National Police, during the election campaign, requires further research and application with regard to the creation of a sustainable system of protection of citizens' electoral rights from unlawful encroachments, as well as the improvement of the prevention of crimes and offences that encroach on election-related legal relations.

Keywords: elections, voters, the electoral process, the implementation of electoral rights and freedoms of participants of the electoral process, violation of electoral legislation.

Отримано 05.06.2019 


\section{АДМІНІСТРАТИВНЕ ПРАВО І ПРОЦЕС. ФIHAHCOBE ПРАВO}

Берлач Наталія Анатоліївна, доктор юридичних наук, професор, провідний науковий співробітник ДНДІ МВС України, м. Київ, Україна,

ORCID ID 0000-0003-0132-7737

\section{ПРО ОСОБЛИВОСТІ ДЕРЖАВНОЇ ПОЛІТИКИ 3 ВІДНОВЛЕННЯ ДЕРЖАВНОГО СУВЕРЕНІТЕТУ УКРАЇНИ В ДОНЕЦЬКІЙ ТА ЛУГАНСЬКІЙ ОБЛАСТЯХ}

У статті досліджено особливості державної політики з відновлення державного суверенітету України в Донещькій та Луганській областях та визначено напрями і необхідні практичні заходи щодо виконання положень вітчизняного та міжнародного законодавства. Визначено обов'язки держави в період врегулювання збройного конфлікту підтримувати $i$ забезпечувати економічні, фінансові, політичні, сочіальні, інформачійні, культурні та інші зв'язки зі співвітчизниками, які проживають на тимчасово окупованій території Украӥни. Окреслено закони, які закріплюють заходи щодо гарантування прав $і$ свобод людини, фінансових та матеріальних благ $і$ забезпечення державного суверенітету Украӥни в Донещькій та Луганській областях.

Ключові слова: державна політика, державний суверенітет, Донещька, Луганська області, міжнародне, вітчизняне законодавство.

Україна є суверенна і незалежна, демократична, соціальна, правова держава; суверенітет України поширюється на всю їі територію, Україна є унітарною державою, територія України в межах існуючого кордону є цілісною і недоторканною [1]. Недоторканність кордонів кожної країни світу є непохитним і обов’язковим принципом державності, суверенітету, основою сталого, самостійного, незалежного, стабільного розвитку як політики, так і економіки, підтримки громадян. I нині Україна робить максимум можливого для відновлення державного суверенітету в Донецькій та Луганській областях.

Метою статті є дослідження особливостей державної політики з відновлення державного суверенітету України в Донецькій та Луганській областях та визначення напрямів і необхідних практичних заходів щодо виконання положень вітчизняного та міжнародного законодавства.

DOI (Article): https: //doi.org/10.36486/np.2019.2.05

(C) Berlach Nataliia, 2019 Issue 2(44) 2019 http://naukaipravoohorona.com/ 
Дослідження державної політики з відновлення державного суверенітету України в Донецькій та Луганській областях є складним і багатоелементним процесом. Визначення напрямів і необхідних практичних заходів щодо виконання положень вітчизняного та міжнародного законодавства також має різновекторну характеристику. Особливості державної політики з відновлення державного суверенітету України в Донецькій та Луганській областях досліджували А. Аржаковський [19], Р. Менон, Е. Румер [18], Т. Грант [17], Ю. В. Ковбасюк, К. Ващенко, Ю. Сурмін [2], В. Сурогацький [25], С. Троян, А. Киридон, [16], О. Лазоренко [20], В. Конах [21], О. Курбан [24], О. Косогов, А. Сірик [23], В. Ткач [22]. Спостерігається зацікавлення цією тематикою спеціалістів, науковців з філософії, політології, соціології, економіки, права.

Під державною політикою слід розуміти сукупність ціннісних цілей, державно-управлінських заходів, рішень і дій, порядок реалізації державно-політичних рішень (поставлених державною владою цілей) і системи державного управління розвитком країни. Уточнимо, що державна політика конструюється для реалізації і зовсім не констатується постфактум. Їй притаманний прагматизм, раціоналізм і діагностованість. Раціональність як базова процесуальна характеристика держави, домінуючий спосіб забезпечення її життєдіяльності також утверджується й шляхом формування державної політики і полягає в практиці узгодження цілей різних груп інтересів через змагальність аргументів, спроби переконання опонентів у справедливості своїх позицій та оцінок. І головний, хоча й не єдиний критерій у цьому процесі, - вартість ресурсів, що виділятимуться для досягнення поставлених цілей. Таким чином, раціональна аргументація - це основний процес, що концептуалізує формування державної політики. Визначальним для державної політики є результат її реалізації, тобто кількісний вимір іiї цілей.

У процесі формування державної політики будь-яка, навіть найскладніша й абстрактна, проблема може бути зведена до певного переліку складових, що мають кількісне вираження. Відомо, що якість управлінської діяльності держави залежить від кількісного виміру показників діяльності її органів влади, насамперед, у частині вираження цілей. Кількісні критерії доцільно застосовувати ще й для зіставлення різних групових інтересів, співвіднесення фінансових витрат на ті чи інші цілі [2].

Процес прийняття державних рішень передбачає:

- постійну орієнтацію всіх структур і органів влади на предметно сформульовані та кількісно визначені цілі (підцілі);

- попередній розрахунок ресурсів, необхідних для їх розробки та реалізації;

- наявність спеціально підготовлених кадрів;

- систематичне залучення незалежної зовнішньої експертизи;

- установлення відповідних компетенцій і повноважень кадрових структур влади, залучених до формування та реалізації конкретних завдань із установленими показниками їх персональної відповідальності;

- підвищення рівня транспарентності, публічності процесу формування державної політики, використання політико-управлінського потенціалу громадянського дискурсу;

- наявність відповідних організаційних механізмів для зниження витрат часу узгоджувального процесу та забезпечення пріоритету раціонально вивірених ці.лей; DOI (Article): https: //doi.org/10.36486/np.2019.2.05 
- якісне зниження орієнтації державних службовців на управлінські практики, що містять множинні девіації, відхилення від норм службової діяльності;

\begin{tabular}{|c|c|c|c|c|}
\hline \multicolumn{5}{|c|}{$\begin{array}{l}\text { КІЛЬКІСТЬ НАСЕЛЕННЯ ДОНЕЩЬКОӦ І ЛУГАНСЬКОЇ ОБЛАСТЕЙ } \\
\text { ЗА ДАНИМИ ДЕРЖСТАТУ УКРАЇНИ, ТИС. ОСІБ }\end{array}$} \\
\hline & 01.01 .2014 & 01.01 .2015 & 01.01 .2016 & 01.01 .2017 \\
\hline $\begin{array}{l}\text { Окуповані території } \\
\text { в їх нинішніх межах }\end{array}$ & 3894 & 3849 & 3828 & 3823 \\
\hline в Донецькій області & 2379 & 2348 & 2334 & 2332 \\
\hline ут. ч. міське населення & 2270 & 2241 & 2228 & 2226 \\
\hline сільське населення & 109 & 107 & 106 & 106 \\
\hline в Луганській області & 1515 & 1501 & 1494 & 1491 \\
\hline ут. ч. міське населення & 1426 & 1413 & 1406 & 1404 \\
\hline сільське населення & 89 & 88 & 88 & 87 \\
\hline $\begin{array}{l}\text { Контрольована Україною } \\
\text { територія }\end{array}$ & 2689 & 2668 & 2643 & 2616 \\
\hline в Донецькій області & 1965 & 1949 & 1931 & 1912 \\
\hline у т. ч. міське населення & 1670 & 1657 & 1642 & 1627 \\
\hline сільське населення & 295 & 292 & 289 & 285 \\
\hline в Луганській області & 724 & 719 & 712 & 704 \\
\hline ут. ч. міське населення & 519 & 515 & 510 & 505 \\
\hline сільське населення & 205 & 204 & 202 & 199 \\
\hline
\end{tabular}

- наявність відповідних фінансових можливостей у держави для підтримки нормативних форм політико-управлінської діяльності [2].

Згідно з наведеними вище даними Держстату [3], чисельність населення на територіях Донбасу, що нині є окупованими, упродовж 2014 р. скоротилася на 45 тис. осіб, 2015 р. - на 21 тис. осіб, 2016 р. - лише на 5 тис. осіб. Така динаміка пояснюється поетапним зменшенням потоку інформації, що надходить до Держстату. У період між переписами населення (а останній було проведено ще в 2001 р.) зміни в чисельності населення кожного населеного пункту обраховуються за даними державних органів, що здійснюють реєстрацію осіб за місцем проживання. Щомісяця розрахункова чисельність коригується шляхом додавання кількості народжених і тих, хто зареєструвався, та віднімання кількості померлих і тих, хто знявся з реєстрації [3]. 3 метою збільшення кількості населення, покращення якості життя громадян, які проживають на тимчасово окупованих територіях у Донецькій і Луганській областях, було прийнято низку законодавчих актів. Одним із таких ключових актів законодавства є прийнятий 18 січня 2018 року Закон України “Про особливості державної політики із забезпечення державного суверенітету України на тимчасово окупованих територіях у Донецькій і Луганській областях", спрямований на правове врегулювання забезпечення державного суверенітету України над тимчасово окупованими територіями. Однак, на нашу думку, наразі більш актуальною є політика насамперед відновлення суверенітету, а не його забезпечення [4].

Крім того, згаданий вище Закон відомий також, як “Закон про реінтеграцію Донбасу”, не містить основного: конкретних шляхів реінтеграції територій Донецької та Луганської областей до складу України. Позитивним у цьому Законі $\epsilon$ те, що, приймаючи його, до уваги брали численні міжнародні договори та звернення Верховної Ради України до міжнародних організацій стосовно втрати

DOI (Article): https: //doi.org/10.36486/np.2019.2.05

(c) Berlach Nataliia, 2019 
Україною суверенних територій. Також цей Закон встановив перелік заходів для забезпечення національної безпеки та оборони, стратегічного керівництва Збройними Силами України та комплексного розвитку безпекової, економічної, інформаційно-телекомунікаційної, соціальної та гуманітарної інфраструктури на територіях, прилеглих до тимчасово окупованих територій в Донецькій та Луганській областях.

Зокрема, у статті 4 Закону України "Про особливості державної політики щодо забезпечення державного суверенітету в Донецькій і Луганській областях" вказується одна з головних цілей державної політики у цій сфері. Це звільнення тимчасово окупованих територій у Донецькій та Луганській областях та відновлення на цих територіях конституційного ладу, що прямо вказує нам на прямий намір держави щодо їх повернення [4]. У статті 5 цього Закону наведений перелік правових, економічних, дипломатичних та інших механізмів, які слугують інструментами держави щодо впровадження політики повернення окупованих територій. У статті 6 вказані напрями дій держави стосовно захисту прав і свобод населення окупованої території, які допомагають відновленню єдності України. Також позитивним у Законі $є$ те, що ним додатково підтверджено непорушне право особи на власність під час воєнних дій. Так, згідно зі ст. 2 цього нормативноправового акта, за фізичними та юридичними особами, а також за суб'єктами публічного права зберігається право власності, інші речові права на майно, у тому числі на нерухоме майно, включаючи земельні ділянки, що знаходиться на тимчасово окупованих територіях у Донецькій та Луганській областях, якщо таке майно набуте відповідно до законів України.

Разом з тим, до недоліків зазначеного Закону України варто віднести його сумнівну практичність та відсутність конкретизації більшості заходів, спрямованих на захист цивільного населення та суверенітету України. Наприклад, у ст. 7 відзначається, що для забезпечення національної безпеки, зокрема державної, економічної, інформаційної, гуманітарної та екологічної, відсічі і стримування збройної агресії Російської Федерації у Донецькій та Луганській областях органи сектору безпеки і оборони, інші державні органи України, їх посадові особи здійснюють заходи для відновлення територіальної цілісності України, а також забезпечують комплексний розвиток безпекової, економічної, інформаційно-телекомунікаційної, соціальної та гуманітарної інфраструктури на територіях, прилеглих до тимчасово окупованих територій в Донецькій та Луганській областях, реалізують, відповідно до документів стратегічного оборонного планування, заходи зі зміцнення оборонних і безпекових спроможностей України.

На нашу думку, варто було б встановити перелік заходів, які мають втілювати державні органи у своїй політиці стосовно цього питання. Такими можуть бути:

1) підтримка оборотності на окупованих територіях єдиної національної валюти України - гривні;

2) унеможливлення корупції серед військових;

3) забезпечення контролю за залученими фінансовими ресурсами в оборонну політику.

Наступною проблемою, яку слід вирішити для швидшого повернення непідконтрольних територій, є фактично запроваджений напіввоєнний стан, що

DOI (Article): https: //doi.org/10.36486/np.2019.2.05

(c) Berlach Nataliia, 2019 
передбачає можливість суттєвого обмеження конституційних прав людини. При чому це відбувається без формального проголошення воєнного стану у порядку, передбаченому Конституцією України. А воєнний чи надзвичайний стан є, як відомо, виключними загальними підставами обмеження прав людини в Україні. Крім того, Конституція забороняє використовувати Збройні Сили для обмеження прав і свобод громадян. Закон містить окрім цього певну колізію 3 іншими актами. Зокрема, ще у 2014 р. на виконання Мінських угод було прийнято Закон від 16.09.2014 № 1680-VII “Про особливий порядок місцевого самоврядування в окремих районах Донецької та Луганської областей” [5], за яким ці території не визнаються окупованими РФ. Щоправда, “особливий порядок” реально настане лише після припинення вогню й проведення місцевих виборів за українськими законами, як це було встановлено у Законі від 06.10.2017 № 2167-VIII "Про створення необхідних умов для мирного врегулювання ситуації в окремих районах Донецької та Луганської областей” [6].

Отже, наведена колізія спричиняє невизначений правовий статус непідконтрольних територій у процесі деескалації конфлікту та проведення місцевих виборів. Закон України “Про особливий порядок місцевого самоврядування в окремих районах Донецької та Луганської областей”, згаданий вище, містить такі позитивні норми [5]:

- Кабмін зобов'язується здійснювати соціально-економічний розвиток Донбасу на підставі угод з органами місцевого самоврядування; запроваджується спеціальний економічний режим для відновлення промисловості регіону, залучення кредитів та інвестицій для його розвитку;

- у держбюджеті має бути захищена стаття видатків на соціально-економічну підтримку регіону.

Щодо недоліків:

- неконституційною є норма про право територіальних громад Донбасу укладати міжнародні угоди “про транскордонне співробітництво”, адже в Україні жодна область чи район не наділені міжнародною правосуб’єктністю, як і у будьякій іншій унітарній державі;

- створення “народної міліції”, власних судів та прокуратури фактично означатиме відсутність реального суверенітету України над Донбасом. При цьому відновлення інфраструктури регіону відбуватиметься коштом усієї України.

Закон України “Про особливості державної політики із забезпечення державного суверенітету України на тимчасово окупованих територіях у Донецькій та Луганській областях", передусім, має на меті відновлення територіальної цілісності України [2]. До основних позитивних сторін можна віднести також визначення принципів захисту прав людини, які постраждали під час ведення бойових дій, визначення заходів безпеки, які застосовуватимуться під час оборони, а також забезпечення незалежності, єдності та територіальної цілісності України, що передбачено у ст. 4. Безумовно, положення ст. 6 є найважливішими, оскільки вони стосуються безпосередньо захисту прав і свобод цивільного населення на тимчасово окупованих територіях. Ще одним плюсом цього Закону є те, що Україна не відходить від курсу політико-дипломатичного врегулювання конфлікту. У статті 7

DOI (Article): https: //doi.org/10.36486/np.2019.2.05

(C) Berlach Nataliia, 2019 Issue 2(4.4) 2019 http://naukaipravoohorona.com/ 
передбачено, що будуть здійснюватися заходи й щодо економічного комплексного розвитку інфраструктури у цих областях.

Недоліком цього Закону є наявність суперечності між ст.ст. 8, 9, 11 Закону та Конституції України, а саме п. 19 ч. 1 ст. 106, оскільки Верховна Рада в неконституційний спосіб дає згоду Президенту на використання Збройних Сил України. А також встановлені обмеження в’їзду та виїзду з тимчасово окупованих областей (ст. 12 Закону), що порушує Конвенцію про захист прав людини і основних свобод, а саме 4 Протоколу [7] до неї та ст. 33 Конституції України.

Щодо фінансового забезпечення на територіях ЛНР та ДНР, є Закон України "Про забезпечення прав і свобод громадян та правовий режим на тимчасово окупованій території України”, де у ч. 2 ст. 5 передбачено, що Україна зобов'язується підтримувати і забезпечувати економічні, фінансові, політичні, соціальні, інформаційні, культурні та інші зв'язки з громадянами України, які проживають на тимчасово окупованій території [8]. У Законі України “Про тимчасові заходи на період проведення антитерористичної операції” [9] встановлюється мораторій на виконання договірних зобов’язань та на нарахування пені та штрафів на основну суму заборгованості за кредитними та іншими договірними зобов'язаннями. Законом України “Про створення вільної економічної зони “Крим” та про особливості здійснення економічної діяльності на тимчасово окупованій території України" [10] врегульовано економічну діяльність на цих територіях, тому було б доречно прийняти подібні закони й на територіях ЛНД та ДНР. Деякі механізми реінтеграції окупованих територій закріплені у Законі України "Про особливий порядок місцевого самоврядування в окремих районах Донецької та Луганської областей” [5], прийнятому 16 вересня 2014 року, яким фактично визначається правовий статус окремих районів Донецької і Луганської областей (ОРДЛО). Цей нормативно-правовий акт насправді є законом про державну політику щодо окупованих територій, що регулює відносини з окупованими територіями та заходи безпеки в регіонах, прилеглих до окупованих територій. Суперечливими $є$ такі його положення: “Україна не несе відповідальність за незаконні дії Російської Федерації чи її окупаційної адміністрації на тимчасово окупованих територіях в Донецькій, Луганській областях або за прийняті ними незаконні рішення” (ч. 6 ст. 6), а "Російська Федерація зобов'язана забезпечити захист прав цивільного населення і створити необхідні умови для його життєдіяльності” (ч. 2 ст. 7). Таким чином, законодавець перекладає відповідальність щодо гарантування прав і свобод власних громадян на іноземну державу, що, звісно ж, є недопустимим.

Незважаючи на те, що однією з основних цілей Закону є “захист прав і свобод цивільного населення, яке постраждало внаслідок російської агресії, ці питання у ньому також врегульовані досить загально. По суті, в нормативно-правовому акті окреслені лише основні напрями захисту прав і свобод цивільного населення на тимчасово окупованих територіях у Донецькій та Луганській областях. Крім того, у документі відсутня соціальна частина, яка змогла б полегшити життя людей, що перебувають на окупованій території, відсутня чіткість у нормативноправовому забезпеченні захисту їх прав і свобод, не врегульований порядок фінансування/здійснення соціальних виплат.

DOI (Article): https: //doi.org/10.36486/np.2019.2.05

(C) Berlach Nataliia, 2019 Issue 2(44) 2019 http://naukaipravoohorona.com/ 
Спроба законодавчого регулювання втілилася у Законі України “Про забезпечення прав і свобод громадян та правовий режим на тимчасово окупованій території України” [8], та більшість норм цього Закону була продубльована і в згаданих вище законах. Проте, як показує практика, наразі відсутній реальний механізм захисту прав людей на окупованих територіях. Деякі гарантії для військовослужбовців закріплені, наприклад, у Законі України "Про соціальний і правовий захист військовослужбовців та членів іх сімей” [11], відповідно до якого на час перебування людини в зоні бойових дій або на час мобілізації скасовується плата відсотків по позикам, проценти за користування кредитом, які були взяті ними як фізичними особами, не нараховуються пільги, пені та штрафні санкції за невиконання зобов'язань перед підприємствами, установами і організаціями усіх форм власності, у тому числі банками, та фізичними особами. Як бачимо, аналізований Закон не є конкретизованим та потребуватиме прийняття ще багатьох підзаконних актів.

Враховуючи зазначене, значна частина положень законодавства має здебільшого декларативний характер. У зв’язку з чим є нагальна необхідність в ухваленні низки законодавчих актів, які б детально регулювали поетапний процес реінтеграції Донбасу, а також формували нову більш ефективну стратегію врегулювання збройного конфлікту, що сприяло б головній меті - відновленню суверенітету та територіальної цілісності України.

Наразі, внаслідок ситуації, що склалася, перед органами публічної та державної влади постає завдання щодо підтримки економічного, соціального, культурного стану непідконтрольних територій Донецької та Луганської областей. Метою діяльності органів державної влади й місцевого самоврядування має стати насамперед створення та реалізація програм підтримки населення, підприємств, малого та середнього бізнесу. Одним із нормативно-правових актів, які потребують аналізу, є Постанова Кабінету Міністрів України від 13 грудня 2017 р. № 1071 "Про затвердження Державної цільової програми відновлення та розбудови миру в східних регіонах України” [12].

Програма спрямована на відновлення соціально-економічного становища населення, про що вказує Розділ “Очікувані результати виконання Програми, ефективність Програми”. У цьому Розділі вказано, зокрема, що результатом має стати підвищення показників індексу валового внутрішнього регіонального продукту, експорту та імпорту товарів та послуг. Але потрібно вказати на недоліки Програми у частині підтримки мікро-, малого та середнього бізнесу.

Постанова Кабінету Міністрів України “Деякі питання фінансування бюджетних установ, здійснення соціальних виплат населенню та надання фінансової підтримки окремим підприємствам і організаціям Донецької та Луганської областей, а також інших платежів з рахунків, відкритих в органах Казначейства" від 7 листопада 2014 р. № 595 встановила фінансове забезпечення бюджетних установ та підтримку підприємств та фізичних осіб. Це було зумовлено переміщенням зазначених установ із непідконтрольних територій. Для надання фінансування Кабінет Міністрів України встановив Тимчасовий порядок фінансування для підтримки подальшого нормального розвитку підприємств та бюджетних установ [13]. Це є позитивним аспектом, тому що, незважаючи на

DOI (Article): https: //doi.org/10.36486/np.2019.2.05

(c) Berlach Nataliia, 2019 
встановлення спеціального режиму в складі Донецької та Луганської областей, держава спрямовує свої зусилля не тільки на вирішення конфлікту, а й на підтримку економічної ситуації, що дає змогу підприємствам, установам та фізичним особам продовжувати свою діяльність та не нести можливих від конфлікту наслідків у вигляді закриття підприємств, суттєвого зниження їх прибутку та ліквідації.

Законодавчими актами, які також регулюють та сприяють відновленню суверенітету та фінансового становища Донецької та Луганської областей, є Закон України "Про тимчасові заходи на період проведення антитерористичної операції" [9], Закон України "Про забезпечення прав і свобод громадян та правовий режим на тимчасово окупованій території України” [8] та інші, також важливим є Закон України "Про надання щомісячної адресної допомоги внутрішньо переміщеним особам для покриття витрат на проживання, в тому числі на оплату житловокомунальних послуг" [14]. Таким чином, помітною є:

- наявність досить великої кількості законодавчих актів, які регулюють ситуацію, що склалася на території Донецької та Луганської областей (втім, вони певною мірою суперечать одне одному, що ускладнює їх застосування);

- визначення компетенції органів державної влади України щодо сприяння не лише звільненню окупованих територій, а й забезпеченню прав і свобод фізичних і юридичних осіб, що на них проживають;

- чітке визначення органу, відповідального за забезпечення соціальноекономічних прав людини на окупованих територіях;

- регулювання соціально-економічних та фінансових прав населення забезпечує Закон України "Про тимчасові заходи на період проведення антитерористичної операції” (наприклад, звільнення від сплати за користування земельними ділянками державної та комунальної власності);

- визначення обов'язків держави в період врегулювання збройного конфлікту: Україна зобов'язується підтримувати і забезпечувати економічні, фінансові, політичні, соціальні, інформаційні, культурні та інші зв’язки з громадянами України, які проживають на тимчасово окупованій території.

Вказані законодавчі акти мають і низку недоліків:

- закони досить загально закріплюють заходи щодо забезпечення прав і свобод людини (щодо забезпечення фінансових та матеріальних благ наявні лише декілька загальних норм, зокрема основними напрямами захисту прав і свобод цивільного населення на тимчасово окупованих територіях у Донецькій та Луганській областях є: сприяння забезпеченню відновлення порушених матеріальних прав; відсутність закріпленого механізму імплементації норм).

Отже, на законодавчому рівні в Україні досить розгалужено регулюється ситуація, яка склалася на території України, що, безперечно, є позитивним моментом. Але варто було б додати дієвий механізм імплементації відповідних норм, а також більш розгалужено закріпити на законодавчому рівні норми щодо забезпечення прав та свобод людини. Тому:

1. Наша держава має рухатися прямим дипломатичним, переговорним шляхом повернення непідконтрольних територій до складу України;

2. Зростання економічного потенціалу держави, на противагу повному занепаду у 2014-2019 рр., дозволить профінансувати додатково з Державного бюджету

DOI (Article): https: //doi.org/10.36486/np.2019.2.05

(c) Berlach Nataliia, 2019 
2020 року Донецьку та Луганську області. Максимум підтримки, а також збільшення заробітної плати в Україні загалом - це стане показником стабільності і на непідконтрольних територіях.

3. Інформаційна сфера є надзвичайно дієвим засобом впливу на суспільну думку (Інтернет, ТБ, радіо, друковані ЗМІ). Нами пропонується вирішення цієї проблеми через спеціальне заохочення каналів до впровадження передач мирного, позитивного, життєстверджуючого змісту, які б показували реальні результати українських підприємств, підприємців, працівників. Поширення міжнаціональної ворожнечі у суспільстві слід вилучити з засобів масової інформації. Необхідно не допускати розбрату, поділу громадян за мовними особливостями, релігійними поглядами, регіональними відмінностями. Міністерство інформаційної політики України має стимулювати діяльність каналів, які б дотримувалися зазначених вимог.

4. Створення комфортних умов проживання громадянам окупованих Донецької і Луганської областей, а також усім громадянам України.

Вважаємо за необхідне, насамперед, визначити стратегію розвитку майбутніх подій. Це можливо лише за умови волевиявлення громадян ДНР і ЛНР під час референдуму та переходу ДНР і ЛНР під юрисдикцію України в результаті дипломатичних переговорів з однозначним виконання Мінських домовленостей та міжнародного права [15].

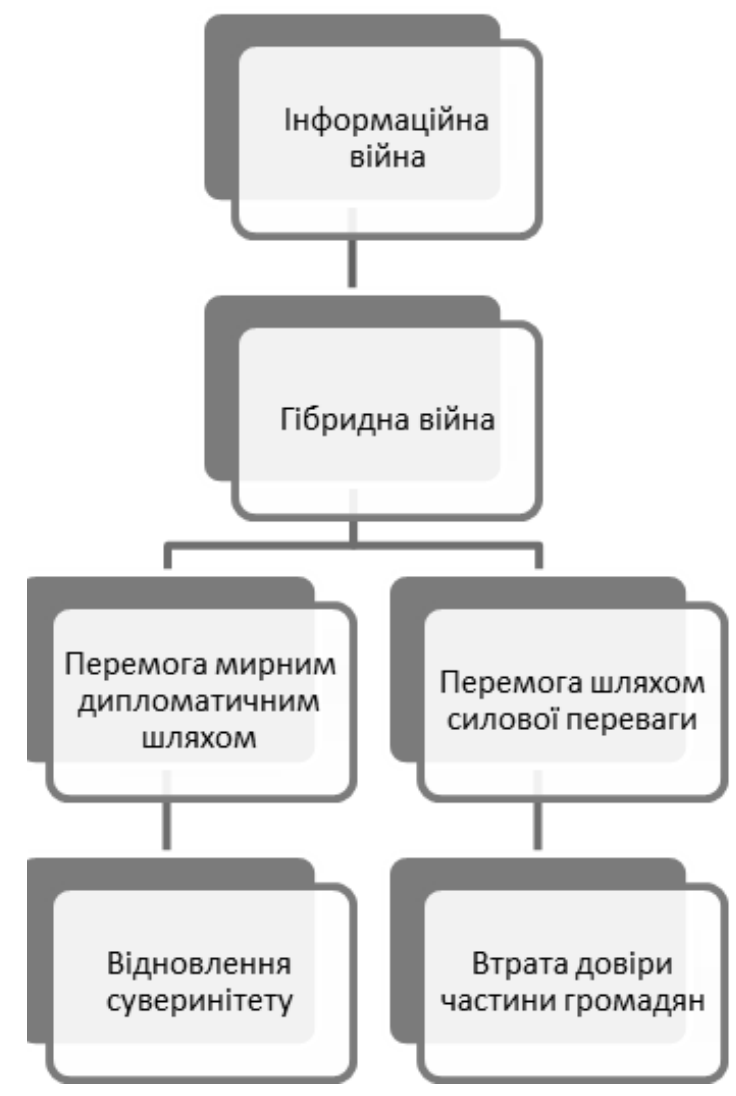

Тому надзвичайно важливими є кроки для розвитку й відновлення

DOI (Article): https: //doi.org/10.36486/np.2019.2.05

(c) Berlach Nataliia, 2019 
державного суверенітету України в Донецькій та Луганській областях мирним дипломатичним шляхом.

Рис. 1. Можливі шляхи розвитку подій.

Українській владі та суспільству слід спершу визначитись, чи варто взагалі повертати Донбас, а одностайного погляду на це питання досі немає. Потрібна, передусім, політична воля, щоб завершити війну і повернути Донецьку та Луганську області до складу України. I перше, що має зробити українська влада, - максимально поширити на вже звільнених територіях сходу дію українських каналів та радіостанцій. Закон України “Про особливості державної політики із забезпечення державного суверенітету України на тимчасових окупованих територіях у Донецькій та Луганських областях” від 18.01.2018 № 2268-VIII [4] має низку позитивних моментів:

- підгрунтя положень - норми Конституції та міжнародні акти;

- особливий порядок забезпечення прав і свобод цивільного населення;

- за державою Україна, територіальними громадами сіл, селищ, міст, розташованих на тимчасово окупованих територіях у Донецькій та Луганській областях, органами державної влади, органами місцевого самоврядування та іншими суб'єктами публічного права зберігається право власності, інші речові права на майно, у тому числі на нерухоме майно, включаючи земельні ділянки, що знаходиться на тимчасово окупованих територіях у Донецькій та Луганській областях (ст. 2);

- питання про залучення ресурсів держави на оборонний та безпековий потенціал України;

- мета - відновлення державного суверенітету України та збереження прав і свобод цивільного населення.

Водночас недоліками є:

недостатній механізм реалізації вказаних положень, особливо щодо збереження прав і свобод (навіть якщо врахувати Закон № 1207-VII за редакцією від 04.11.2018, де враховані лише деякі аспекти як загальне);

недостатнє уточнення фінансового підгрунтя (залучення коштів держави/ міжнародна допомога);

занадто загальне викладення “шляхів” для подолання конфлікту, оскільки все грунтується лише на словах про права і свободи, механізм захисту яких потребує вдосконалення;

наразі немає вагомого результату з погляду практичної реалізації цих положень.

Проте виправити недоліки можливо за допомогою:

1) конкретного визначення джерел фінансування та механізму контролю за залученими коштами;

2) визначення шляхів забезпечення стабільності економіки на непідконтрольних територіях;

3) розроблення механізму захисту прав і свобод цивільного населення.

DOI (Article): https: //doi.org/10.36486/np.2019.2.05

(C) Berlach Nataliia, 2019 
Беручи до уваги Закон України “Про забезпечення прав і свобод громадян та правовий режим на тимчасово окупованій території України” за редакцією від 04.11.2018 №1207-VII, можемо зазначити такі його позитивні сторони [8], як:

- конституційне та міжнародно-правове підгрунтя (щодо прав і свобод);

• визначення особливостей діяльності державних органів, органів місцевого самоврядування, підприємств, установ і організацій на непідконтрольних територіях;

• зобов'язання України підтримувати і забезпечувати економічні, фінансові, політичні, соціальні, інформаційні, культурні та інші зв'язки з громадянами України, які проживають на тимчасово окупованій території;

- встановлення заходів правового реагування на вказаній території;

- гарантування права власності та правовий режим майна в межах збройного конфлікту.

Особливими проблемами, які потребують вирішення, є особливості приватизації жилих приміщень, що знаходяться на тимчасово окупованій території, військовослужбовцями військових формувань та правоохоронних органів України (можливість наявності свавілля за відсутності нормального врегулювання питання власності на окупованій території).

Такі недоліки можливо виправити шляхом:

1) відновлення порушених прав громадян України спеціальними уповноваженими органами на національному рівні;

2) уточнення щодо економічних / фінансових / соціальних зв'язків підтримки населення, оскільки в Законі відсутнє будь-яке питання фінансового підгрунтя;

4) деталізації питання про унеможливлення корупції серед військовослужбовців;

5) контролю за залученими коштами на забезпечення охорони прав і свобод людини та оборонної політики.

Українська держава визнає Донбас невід'ємною частиною України. Одним із ключових завдань державної політики є реінтеграція непідконтрольних територій Донецької та Луганської областей і громадян України, які на них проживають. Переконання громадян України на окремих територіях Донецької та Луганської областей формуються в умовах закритого інформаційного простору, внаслідок чого у жителів непідконтрольних регіонів складається негативний образ щодо України.

Інформаційна реінтеграція непідконтрольних територій - це один із пріоритетних кроків у забезпеченні конституційних прав громадян України, які проживають у цій місцевості, а крім того, це одна з умов відновлення територіальної цілісності та суверенітету України. Особливої уваги заслуговують:

1. Нейтралізація інформаційного впливу, що несе загрозу національній безпеці України, та протидія йому.

2. Зміцнення почуття спільності між громадянами України, які проживають на підконтрольних і тимчасово непідконтрольних територіях Донецької та Луганської областей, а також громадянами України, які проживають в інших регіонах України.

3. Створення у свідомості громадян України, які проживають на території Донецької та Луганської областей, позитивного іміджу України.

DOI (Article): https: //doi.org/10.36486/np.2019.2.05

() Berlach Nataliia, 2019 
4. Підвищення рівня української громадянської ідентичності та свідомості серед громадян України, які проживають у Донецькій та Луганській областях.

Для сприяння формуванню таких переконань у жителів підконтрольних і непідконтрольних територій областей необхідні, передусім, сталий розвиток Донецької та Луганської областей за сприяння держави, а також упевнений курс на євроінтеграцію.

\section{СПИСОК ВИКОРИСТАНИХ ДЖЕРЕЛ}

1. Конституція України. URL: https://www.president.gov.ua/documents/constitution (дата звернення: 15.03.2019).

2. Державна політика: підручник. Нац. акад. держ. упр. при Президентові України; ред. кол.: Ю.В. Ковбасюк (голова), К.О. Ващенко (заст. голови), Ю.П. Сурмін (заст. голови) та ін. К.: НАДУ, 2014. 448 с.

3. URL: http://www.dsnews.ua/static/longread/donbas-ukr/demographiya-ordlo.html (дата звернення: 15.03.2019).

4. Про особливості державної політики із забезпечення державного суверенітету України на тимчасово окупованих територіях у Донецькій та Луганській областях: Закон України від 18 січня 2018 р. № 2268-VIII. URL: https://zakon.rada.gov.ua/laws/show/2268-19 (дата звернення: 15.03.2019).

5. Про особливий порядок місцевого самоврядування в окремих районах Донецької та Луганської областей: Закон України від 16.09.2014 № 5081. URL: https://zakon.rada.gov.ua/ laws/show/1680-18 (дата звернення: 15.03.2019).

6. Про створення необхідних умов для мирного врегулювання ситуації в окремих районах Донецької та Луганської областей: Закон України від 06.10.2017 № 2167-VIII. URL: https:// zakon.rada.gov.ua/laws/show/2167-19 (дата звернення: 15.03.2019).

7. Конвенція про захист прав людини і основоположних свобод. URL: https://zakon. rada.gov.ua/laws/show/995_004 (дата звернення: 15.03.2019).

8. Про забезпечення прав і свобод громадян та правовий режим на тимчасово окупованій території України” Закон України від 04.11.2018 № 2581-VIII. URL: https://zakon.rada.gov.ua/ laws/show/1207-18] (дата звернення: 15.03.2019).

9. Про тимчасові заходи на період проведення антитерористичної операції: Закон України від 07.02.2019 № 2473-VIII. URL: https://zakon.rada.gov.ua/laws/show/1669-18 (дата звернення: 15.03.2019).

10. Про створення вільної економічної зони "Крим" та про особливості здійснення економічної діяльності на тимчасово окупованій території України: Закон України 12.08.2014 № 1636-18. URL: https://zakon.rada.gov.ua/laws/show/1636-vii (дата звернення: 15.03.2019).

11. Про соціальний і правовий захист військовослужбовців та членів їх сімей: Закон України від 01.01.2019 № 2629-VIII. URL: https://zakon.rada.gov.ua/laws/show/2011-12 (дата звернення: 15.03.2019).

12. Про затвердження Державної цільової програми відновлення та розбудови миру в східних регіонах України: постанова Кабінету Міністрів України від 13 грудня 2017 р. № 1071. URL: https://zakon.rada.gov.ua/laws/show/1071-2017-\%D0\%BF (дата звернення: 15.03.2019).

13. Деякі питання фінансування бюджетних установ, здійснення соціальних виплат населенню та надання фінансової підтримки окремим підприємствам і організаціям Донецької та Луганської областей, а також інших платежів з рахунків, відкритих в органах Казначейства: постанова Кабінету Міністрів України від 7 листопада 2014 р. № 595. URL: https:// zakon.rada.gov.ua/laws/show/595-2014-\%D0\%BF (дата звернення: 15.03.2019).

14. Про надання щомісячної адресної допомоги внутрішньо переміщеним особам для покриття витрат на проживання, в тому числі на оплату житлово-комунальних послуг: Закон України від 08.09.2018. № 713. URL: https://zakon.rada.gov.ua/laws/show/505-2014-\%D0\%BF (дата звернення: 15.03.2019).

15. Рамочне рішення Трьохсторонньої контактної групи про розведення сил і засобів від 20.09.2016. URL: https://www.osce.org/ru/cio/266271?download=true (дата звернення: 15.03.2019).

16. Троян С., Киридон А. Грузія 2008 - Україна 2014: запаралелення російських стратегій. Зовнішні справи. 2014. № 8. С. 33-37.

DOI (Article): https: //doi.org/10.36486/np.2019.2.05

(C) Berlach Nataliia, 2019 
17. Thomas D. Grant, (англ.) Aggression against Ukraine. Territory, Responsibility, and International Law. Palgrave Macmillan, 2015.

18. Rajan Menon, Eugene B. Rumer, (англ.) Conflict in Ukraine. The Unwinding of the PostCold War Order. The MIT Press, 2015.

2014.

19. Antoine Arjakovsky, (фр.) Russie-Ukraine, de la guerre a la paix? Paris: Parole et Silence,

20. Лазоренко O.A. Інформаційний складник гібридної війни Російської Федерації проти України: тенденції розвитку. Стратегічні пріоритети. Національний інститут стратегічних досліджень, 2015. Т. 36.

21. Конах В.К. Сучасні тенденції в захисті національних медіапросторів від російської пропаганди. Стратегічні пріоритети. Національний інститут стратегічних досліджень, 2016. Т. 38.

22. Ткач В.Ф. Спецпропаганда як інформаційний складник гібридної війни Росії проти України. Стратегічні пріоритети. Національний інститут стратегічних досліджень, 2016. Т. 38.

23. Косогов O.M., Сірик А.О. Завдання захисту національного інформаційного простору за досвідом ведення гібридної війни РФ на Сході України. Системи озброєння і військова техніка. 2017. С. $38-41$.

24. Курбан О. Медіавіруси та їх використання як інформаційної зброї. Наукові записки (Українська академія друкарства). 2016. № 1. С. 267-271.

25. Стругацький B. Маніпулятивні практики на тлі гібридної війни. Філософський аналіз. Київ: ФОП Халіков Р.Х., 2018. 166 с.

\section{REFERENCES}

1. Constitution of Ukraine. Bulletin of Verkhovna Rada of Ukraine. 1996. No 30. Art. 141 (date of application: 15.03.2019) [in Ukrainian].

2. Derzhavna polityka: pidruchnyk. Nats. akad. derzh. upr. pry Prezydentovi Ukrayiny. "Public policy": a textbook. Nat. Acad. state. ref. under the President of Ukraine; ed. qty.: Yu.V. Kovbasyuk (chairman), K.O.Vashchenko (deputy chairman), Yu. P. Surmin (deputy chairman) and others. Textbook. Kyiv: National Academy of State Administration. 2014. 448 p. [in Ukrainian].

3. Demohrafiia ORDLO. "Demography of Temporarily occupied and uncontrolled territories of Ukraine" http://www.dsnews.ua/static/longread/donbas-ukr/demographiya-ordlo.html (date of application: 15.03.2019) [in Ukrainian].

4. Pro osoblyvosti derzhavnoyi polityky iz zabezpechennia derzhavnoho suverenitetu Ukrainy na tymchasovo okupovanykh terytoriiakh u Donetskyi ta Luhanskyi oblastiakh. "On features of the state policy of ensuring of the sovereignty of Ukraine on temporary occupied territories of Donetsk and Lugansk regions": Law of Ukraine of 18.09.2018 No 2268-VIII. URL: https://zakon.rada.gov.ua/ laws/show/1680-18.(date of application: 15.03.2019) [in Ukrainian].

5. Pro osoblyvyi poriadok mistsevoho samovriaduvannia v okremykh rayonakh Donetskoi ta Luhanskoi oblastey. "On the special order of the local government in particular districts of Donetsk and Lugansk regions": Law of Ukraine of 16.09.2014. No. 5081. URL: https://zakon.rada.gov.ua/ laws/show/1680-18 (date of application: 15.03.2019) [in Ukrainian].

6. Pro stvorennia neobkhidnykh umov dlia myrnoho vrehuliuvannia sytuatsii v okremykh rayonakh Donetskoi ta Luhanskoi oblastei. "On the establishment of necessary conditions for a peaceful resolution of the situation in particular districts of Donetsk and Lugansk regions": Law of Ukraine of 06.10.2017 No. 2167-VIII. URL: https://zakon.rada.gov.ua/laws/show/2167-19 (date of application: 15.03.2019) [in Ukrainian].

7. Konventsiia pro zakhyst prav liudyny i osnovopolozhnykh svobod. "European Convention on Human Rights of 4.11.1950". URL: https://www.coe.int/en/web/conventions/full-list/-/ conventions/rms/0900001680063765 (date of application: 15.03.2019) [in Ukrainian].

8. Zakon Ukrainy "Pro zabezpechennia prav i svobod hromadian ta pravovyi rezhym na tymchasovo okupovanii terytorii Ukrainy". "On securing the rights and freedoms of the people and the legal regime on the temparary occupied territory of Ukraine”: Law of Ukraine of 15.04.2014. №. № 2581VIII. URL: https://zakon.rada.gov.ua/laws/show/1207-18 (date of application: 15.03.2019) [in Ukrainian].

9. Pro tymchasovi zakhody na period provedennia antyterorystychnoi operatsii. "On temporary measures for the period of the anti-terrorist operation": Law of Ukraine of 02.09.2014 No. 2473-VIII. URL: https://zakon.rada.gov.ua/laws/show/1669-18 (date of application: 15.03.2019) [in Ukrainian].

DOI (Article): https: //doi.org/10.36486/np.2019.2.05

(C) Berlach Nataliia, 2019 
10. Pro stvorennia vilnoi ekonomichnoi zony "Krym" ta pro osoblyvosti zdiisnennia ekonomichnoi diialnosti na tymchasovo okupovanii terytorii Ukrainy. "On the creation of the free economic zone "Crimea" and on the features of the economic activity on the temporary occupied territory of Ukraine”: Law of Ukraine of 12.08.2014 No. 1636-VII. URL: https://zakon.rada.gov.ua/laws/show/ 1636-vii (date of application: 15.03.2019) [in Ukrainian].

11. Pro sotsialnyi i pravovyi zakhyst viiskovosluzhbovtsiv ta chleniv yikh simei. "On the social and legal protection of military servicemen and their families": Law of Ukraine of 20.12.1991 No. 2011-XII. URL: https://zakon.rada.gov.ua/laws/show/2011-12 (date of application: 15.03.2019) [in Ukrainian].

12. Pro zatverdzhennia Derzhavnoi tsilovoi prohramy vidnovlennia ta rozbudovy myru v skhidnykh rehionakh Ukrainy. "On approval of the State target programme for restoration and extention of peace in the eastern regions of Ukraine": Decree of the Cabinet of Ministers of Ukraine of 13.12.2017 No. 1071. URL: https://zakon.rada.gov.ua/laws/show/1071-2017-\%D0\%BF (date of application: 15.03.2019) [in Ukrainian].

13. Some issues of financing of budgetary institutions, making social payments to the population and providing financial support to individual enterprises and organizations of Donetsk and Lugansk regions, as well as other payments from accounts opened in Treasury bodies: Resolution of the Cabinet of Ministers of Ukraine of 7.11.2014 No. 595. URL: https://zakon.rada.gov.ua/laws/show/ 595-2014-\%D0\%BF (date of application: 15.03.2019) [in Ukrainian].

14. Pro nadannia shchomisiachnoi adresnoi dopomohy vnutrishno peremishchenym osobam dlia pokryttia vytrat na prozhyvannia, v tomu chysli na oplatu zhytlovo-komunalnykh posluh. "On providing of monthly targeted assistance to internally displaced persons to cover living expenses, including the payment of utility costs": Law of Ukraine of 08.09.2018 No. 713. URL: https://zakon.rada.gov.ua/ laws/show/505-2014-\%D0\%BF (date of application: 15.03.2019) [in Ukrainian].

15. Ramochne rishennia Trystoronnoi kontaktnoi hrupy pro rozvedennia syl i zasobiv vid 20.09.2016. "Framework decision of the Tripartite Contact Group on the separation of forces and means on 20.09.2016". URL: https://www.osce.org/ru/cio/266271?download=true (date of application: 15.03.2019) [in Ukrainian].

16. Troian S., Kiridon A. (2014) Hruziia 2008 - Ukraina 2014: zaparalelennia rosiyskykh stratehem. "Georgia 2008 - Ukraine 2014: parallelization of Russian strategies". Foreign Affairs. Vol. 8. P. 33-37 [in Ukrainian].

17. Thomas D. Grant (2015) Aggression against Ukraine. Territory, Responsibility, and International Law. Palgrave Macmillan. 283 p. [in English].

18. Ryan Menon, Eugene B. Rumer (2015) Conflict in Ukraine. The Unwinding of the PostCold War Order. The MIT Press. 248 p. [in English].

19. Antoine Arjakovsky (2014) Russie-Ukraine, de la guerre a la paix? "Russia-Ukraine, from war to peace?". Paris: Parole et Silence. 352 p. [in French].

20. Lazorenko O.A. (2015) Informaciinyi skladnyk hibrydnoi viiny Rosiiskoi Federacii proty Ukrainy: tendencii rozvytku. "Information component of the hybrid war of the Russian Federation against Ukraine: development tendencies". Strategic priorities. National Institute for Strategic Studies. Vol. 36, P. 124-133 [in Ukrainian].

21. Konakh V.K. (2016) Suchasni tendencii v zakhysti natsionalnykh mediaprostoriv vid rosiiskoi propahandy. "Modern trends in the protection of national media spaces from Russian propaganda". Strategic priorities. National Institute for Strategic Studies. Vol. 38. P. 88-98 [in Ukrainian].

22. Tkach V.F. (2016) Spetspropahanda yak informaciinyi skladnyk hibrydnoi viiny Rosiyi proty Ukrainy. "Special propaganda as an information component of Russia's hybrid war against Ukraine". Strategic Priorities. National Institute for Strategic Studies. Vol. 38. P. 99-109 [in Ukrainian].

23. Kosohov O.M., Sirik A.A. (2017) Zavdannia zakhystu natsionalnoho informatsiinoho prostoru za dosvidom vedennia hibrydnoi viiny RF na Shodi Ukrainy. "Tasks of protection of the national information space based on the experience of hybrid war of the Russian Federation in the East of Ukraine". Armament systems and military equipment . Vol. 49. P. 38-41 [in Ukrainian].

24. Kurban O. (2016) Mediavirusy ta yix vykorystannIa yak informatsiinoi zbroi. "Mediaviruses and their application as information weapons". Scientific Notes Ukrainian Academy of Printing. Vol.1

P. 267-271 [in Ukrainian].

25. Struhatskyi V. (2018) Manipuliatyvni praktyky na tli hibrydnoi viiny. Filosofskyi analiz. "Manipulative practices on the background of hybrid war. Philosophical analysis". Kyiv: FOP

A.D. Khalikov.P. Kh. 166 p. [in Ukrainian].

DOI (Article): https: //doi.org/10.36486/np.2019.2.05

(c) Berlach Nataliia, 2019 
Berlach Nataliia, Doctor of Juridical, Professor, Leading Researcher, State Research Institute MIA Ukraine, Kyiv, Ukraine, ORCID ID 0000-0003-0132-7737

\section{PECULARITIES OF STATE POLICY ON RESTORATION OF STATE SOVEREIGNTY OF UKRAINE IN DONETSK AND LUHANSK REGIONS}

The article considers the legal basis and main directions of the state policy on restoration of state sovereignty of Ukraine in Donetsk and Luhansk regions. The obligations of the Ukrainian state during the regulation of the armed conflict are defined with respect to supporting and ensuring of financial, political, social, informational, cultural and other ties with compatriots who live in the temporarily occupied territories of Ukraine. Relevant legislation is analysed, while the author also suggests directions for its improvement as well. Among the legal acts that define measures to guarantee human rights and freedoms, financial and material benefits and ensure the state sovereignty of Ukraine in Donetsk and Luhansk regions, we analyse the following ones: "On ensuring of rights and freedoms of citizens and the legal regime in the occupied territory of Ukraine", "On the special order of local selfgovernment in some areas of Donetsk and Lugansk oblasts", and others. Attention is drawn to a large number of specific legal acts in the analyzed area. Nevertheless, they include a range of contradictory provisions and gaps which complicate the proper application thereof. Therefore, the necessity of unification of the legal basis is pointed out as an important step in this domain. It is proposed to change the vector of activity of the state authorities of Ukraine from the mere liberation of the occupied territories to better ensuring of rights and freedoms of individuals and legal entities residing in non-controlled territories. These two objectives are considered as interconnected and achieving of the one would promote the achieving of the other. The necessity of a clear definition of the authority responsible for ensuring of socio-economic human rights in these territories is also emphasised in the article. Attention was paid, among other aspects, to maintaining of the turnover of the sole national currency of Ukraine - hryvnia - in the occupied territories, preventing corruption among the military in the region, ensuring of the control over the financial resources involved in defence policy. The research suggests and reasons strengthening of efforts to reintegrate and reunify the non-controlled territories of Donetsk and Luhansk regions to Ukraine by means of infrastructural, socio-economic, political and cultural inclusion with the rest of Ukrainians.

Keywords: administrative and legal regulation, national unity, state sovereignty, Donetsk, Luhansk regions, territorial integrity of Ukraine.

Отримано 05.06.2019

DOI (Article): https: //doi.org/10.36486/np.2019.2.05

(c) Berlach Nataliia, 2019 
УДК 342.9

Білоус Віктор Тарасович, доктор юридичних наук, професор, професор Університету державної фіскальної служби України,

м. Ірпінь, Україна

Стасюк Оксана Леонідівна, кандидат юридичних наук, здобувач ДНДІ МВС України, м. Київ, Україна

\section{АДМІНІСТРАТИВНО-ПРАВОВІ ГАРАНТІЇ РЕАЛІЗАЦІї ПРАВОЗАХИСНОЇ ФУНКЦІї В УКРАЇНІ}

Стаття присвячена дослідженню адміністративно-правових гарантій реалізачї правозахисної функцї держави. Розкрито сутність юридичних гарантій та виокремлено серед них адміністративно-правові. Аргументовано, що адміністративно-правові гарантії охорони прав, свобод і законних інтересів людини і громадянина та адміністративно-правові гарантії захисту прав, свобод $і$ законних інтересів людини і громадянина - це окремі види адміністративно-правових гарантій. Запропоновано авторсъке розуміння адміністративно-правових гарантій реалізаціі правозахисної функції. Наведено ознаки адміністративно-правових гарантій реалізащї правозахисної функщії. Наголошено на необхідності удосконалення системи адміністративно-правових гарантій та розв'язання існуючих у правозахисній сфері проблем.

Ключові слова: правозахисна функиія, адміністративно-правове забезпечення, адміністративно-правові гарантї, адміністративно-правові відносини, права та свободи людини і громадянина, органи публічної влади.

Відповідно до чинного законодавства кожен має право звертатися за захистом своїх порушених прав, свобод і законних інтересів. Водночас недостатньо лише задекларувати таке право. Необхідно також створити належні умови для реалізації цього права, тобто встановити певні юридичні гарантії його забезпечення. Правові гарантії захисту прав, свобод і законних інтересів залежать, насамперед, від ефективної діяльності і взаємодії органів публічної влади у правозахисній сфері. Відповідно до того, наскільки чітко визначено адміністративно-правове забезпечення юридичних гарантій правозахисного спрямування, залежить і ефективність захисту прав, свобод і законних інтересів суспільства. У зв’язку з цим важливого значення набуває наукове осмислення адміністративно-правових гарантій реалізації правозахисної функції в Україні.

Проблематиці юридичних гарантій, зокрема адміністративно-правових, присвячені праці таких учених, як В.Б. Авер'янов, О.М. Бандурка, Ю.П. Битяк, Є.В. Білозьоров, І.Л. Бородін, А.М. Колодій, Е.О. Олефіренко, В.Ф. Погорілко, П.М. Рабінович, О.Ф. Скакун, В.О. Тімашов та ін. Однак науковий аналіз цього питання $з$ акцентом на адміністративно-правове забезпечення реалізації

DOI (Article): https://doi.org/10.36486/np.2019.2.06

(C) Bilous Viktor, Stasiuk Oksana, 2019 
правозахисної функції в Україні до цього часу не є досконало вивченими, що зумовлює необхідність проведення дослідження з означеної проблематики.

Метою статті є визначення сутності, місця та ролі адміністративно-правових гарантій у забезпеченні реалізації правозахисної функції в Україні.

Слід нагадати, що слово “гарантія” означає поруку, умову, котра забезпечує що-небудь [1, с. 111]. Це явище, яке забезпечує досягнення конкретного результату, створює умови для функціонування певних суспільних відносин [2, с. 130]. Термін “гарантія" широко використовується у багатьох галузях науки. Одним із самостійних видів гарантій є правові гарантії. У юридичній науці наявні різні позиції щодо розуміння поняття “юридичні гарантії”.

Так, С.С. Алексєєв під гарантіями розуміє умови й особливі юридичні механізми, покликані забезпечити фактичну реалізацію законоположень [3, с. 135]. На думку М.С. Малеіна, юридичні гарантії - це норми права, які передбачають у своїй сукупності правовий механізм, покликаний сприяти реалізації законів. Якісна характеристика юридичних гарантій передбачає оцінку всієї діючої системи права в цілому, з погляду повноти охоплення правовим інструментарієм усіх найбільш важливих взаємовідносин державних органів та громадян, а також громадян між собою [4, с. 43]. У свою чергу О.Ф. Фрицький вважає, що правові гарантії - це надання державою формальної (юридичної) загальнообов’язковості умовам, необхідним для того, щоб кожна людина могла скористатися особистими правами і свободами [5, с. 177].

3'ясовуючи роль органів державної влади у забезпеченні прав людини і громадянина в демократичному суспільстві, Б.І. Стахура відзначає, що у широкому сенсі під “гарантіями” слід розуміти всю сукупність об’єктивних і суб'єктивних чинників, спрямованих на повну реалізацію і всебічну охорону прав і свобод громадян, на усунення причин і умов їх неналежного здійснення і захист від порушень. Встановлюючи зміст і обсяг прав і свобод людини, держава бере на себе гарантію виконання цих установок. Більше того, враховуючи, що реалізація прав і свобод громадян неминуче пов’язана із необхідністю застосування заходів процесуального примусу, держава змушена виробити дієвий механізм, що обмежує домагання органів державної влади на безроздільне панування у сфері регулювання взаємовідносин із населенням. У цьому плані гарантії можуть розглядатися як система умов, засобів і способів, що забезпечують рівні можливості для виявлення, набуття і реалізації прав і свобод [6, с. 91].

Серед науковців немає єдиного підходу щодо складу юридичних гарантій. Зокрема, В.А. Патюлін до юридичних гарантій відносить лише юридичні норми визначеного різновиду, так звані нормативно-правові засоби забезпечення законності [7, с. 237-239]. Натомість М.В. Вітрук до складу юридичних гарантій, крім нормативно-правових засобів забезпечення законності, включає також діяльність державних органів (зокрема і суспільних об'єднань), що регулюються цими нормами [8, с. 204-205]. С.Г. Стеценко виділяє такі види правових гарантій: а) стан законодавства, його стабільність і відповідність розвитку відносин у суспільстві, рівень юридичної техніки; б) стан діяльності з попередження і припинення правопорушень, зокрема, заходів юридичної відповідальності; в) доступність і якість правосуддя; г) ефективність контролю за реалізацією правових актів [9, с. 195].

DOI (Article): https://doi.org/10.36486/np.2019.2.06

(C) Bilous Viktor, Stasiuk Oksana, 2019

Issue 2(4.4) 2019

http://naukaipravoohorona.com/ 
3 цього приводу Б.І. Стахура цілком слушно наголошує, що засоби і способи юридичних гарантій досить різноманітні, але їх об'єднує тільки їм притаманна властивість - всі вони закріплені в законодавстві і пов’язані із застосуванням правових норм. У механізмі соціально-правового захисту прав людини юридичні гарантії мають самостійне значення. Головний принцип побудови системи юридичних гарантій - загальний захист прав і свобод за допомогою застосування правових норм. Однак не всі правові норми є юридичною гарантією, а лише ті, які містять певні засоби і способи безперешкодного користування ними для захисту прав і свобод, а також їх відновлення у разі порушення [6, с. 95].

3 огляду на викладене, можна констатувати, що правові гарантії реалізації правозахисної функції - це правові норми, за допомогою яких забезпечується належний захист прав, свобод і законних інтересів людини і громадянина. За галузями права як різновидом правових гарантій виділяються адміністративноправові гарантії, що реалізуються за допомогою адміністративно-правових відносин.

З’ясовуючи особливості дотримання прав і свобод громадян у діяльності міліції, М.Т. Какимжанов адміністративно-правові гарантії прав визначив через адміністративно-правові гарантії, що забезпечують реалізацію прав і свобод особистості та адміністративно-правові гарантії їхньої охорони (захисту). На його думку, зміст адміністративно-правових гарантій полягає у практичному здійсненні органами управління (посадовими особами) юридично значущих дій: виконання юридичного обов'язку щодо забезпечення реалізації прав і свобод громадян; створення умов для їх реалізації; постійне спостереження за їх реалізацією; охорона, захист прав і свобод громадян; застосування санкцій у разі їхнього порушення $[10$, c. $17-18]$.

Інші науковці вважають, що гарантії адміністративно-правового захисту правових можливостей громадян охоплюють широку систему інструментів, які сприяють забезпеченню законності в суспільних відносинах [11, с. 13] та практичного значення набувають через норми права, правозастосовну діяльність, індивідуальні юридичні акти, що дають змогу громадянину самостійно або за сприяння органів публічного управління забезпечити реалізацію потреб, здійснити протидію правопорушенням, відновити правові можливості, відшкодувати заподіяну шкоду [12, с. 331-332].

Розглядаючи адміністративно-правові гарантії реалізації прав та свобод громадян, Е.О. Олефіренко доходить висновку, що під ними слід розуміти урегульовану адміністративно-правовими нормами діяльність уповноважених органів (посадових осіб) у сфері державного управління, спрямовану на адекватне розуміння i застосування чинного законодавства, яке визначає права та свободи громадян. До системи таких гарантій варто відносити: ефективну правотворчу, правозастосовну, організаційну діяльність органів державного управління. Зміст адміністративноправових гарантій реалізації прав та свобод громадян полягає у ефективному практичному здійсненні органами державного управління відповідно до законів і підзаконних актів, юридичних обов’язків з приводу втілення в життя прав і свобод громадян. Адміністративно-правові гарантії реалізації прав і свобод громадян за змістом і об'ємом охоплюють суспільні відносини в різних сферах

DOI (Article): https://doi.org/10.36486/np.2019.2.06

(C) Bilous Viktor, Stasiuk Oksana, 2019 
життєдіяльності держави. Їх особливістю є те, що вони виникають у процесі управлінської діяльності органів держави [13, с. 12].

Варто відзначити, що деякі дослідники ототожнюють адміністративно-правові гарантії охорони прав, свобод і законних інтересів людини і громадянина з адміністративно-правовими гарантіями захисту прав, свобод і законних інтересів людини і громадянина. Наприклад, Т.I. Котормус визначає адміністративно-правові гарантії захисту права власності громадян України як сукупність забезпечених державою умов, адміністративно-правових способів та засобів протидії порушенню права власності громадян України, попередження, припинення адміністративних порушень у цій сфері, відновлення порушених прав щодо володіння, користування та розпорядження майном [14, с. 253]. На наше переконання, адміністративно-правові гарантії охорони прав, свобод і законних інтересів людини і громадянина та адміністративно-правові гарантії захисту прав, свобод і законних інтересів людини і громадянина - це окремі види адміністративно-правових гарантій.

Визначальним у вирішенні цього питання є відмежування таких категорій, як “захист” та “охорона", оскільки саме вони застосовуються в одному значенні адміністративно-правових гарантій охорони та захисту прав, свобод і законних інтересів людини і громадянина. Охорону можна розглядати як систему законодавчо встановлених матеріальних правових гарантій, а також діяльність уповноважених на те органів за їх реалізацією з метою запобігання порушенням норм чинного законодавства. У свою чергу захист прав - це сукупність заходів організаційноправового характеру, що реалізуються компетентними державними органами та організаціями, яким таке право надано чинним законодавством, у межах юридичного процесу (юридичних процедур) з метою відновлення порушеного права, усунення перешкод у його реалізації, усунення реальної загрози порушення суб'єктивних прав протиправними діями, а також із метою застосування до порушника заходів правового примусу [15, с. 81].

До характерних ознак адміністративно-правових гарантій належать такі: $є$ похідними від початкового і універсального гаранта прав осіб, яким є Конституція України та інші закони; виступають елементом адміністративно-правового статусу осіб; відносяться до рівня реалізації прав, свобод і законних інтересів осіб; мають обслуговуючий, оберігаючий характер стосовно наданих законом прав учасників адміністративно-правових відносин; покликані охороняти і захищати права осіб, у зв'язку з чим відносяться до правозахисного інституту; потреба в зверненні до них виникає у зв’язку з практичною діяльністю органів публічної влади щодо реалізації покладених на них функцій; мають особливу юридичну силу, спрямовану на подолання перешкод, що стоять на шляху задоволення інтересів і реалізації прав та свобод осіб; спричиняють у своєму застосуванні до юридичних наслідків і конкретних результатів; реалізуються в межах врегульованого нормами адміністративного правопорядку та відповідно до встановлених адміністративних процедур; забезпечуються державою [16, с. 167].

Наведені особливості дозволяють стверджувати, що адміністративно-правові гарантії застосовуються як до адміністративного права загалом, так і до окремих

DOI (Article): https://doi.org/10.36486/np.2019.2.06

(C) Bilous Viktor, Stasiuk Oksana, 2019

Issue 2(44) 2019

http://naukaipravoohorona.com/ 
видів адміністративно-правових відносин, у тому числі у сфері захисту прав, свобод і законних інтересів осіб. Відповідно, адміністративно-правові гарантії реалізації правозахисної функції є особливим видом загальної категорії “адміністративноправові гарантії”. На нашу думку, адміністративно-правові гарантії реалізації правозахисної функції - це врегульована адміністративно-правовими нормами правозахисна діяльність органів публічної влади, спрямована на створення належних умов для відновлення порушеного права, усунення перешкод у його реалізації, усунення реальної загрози порушення суб'єктивних прав протиправними діями та застосування до порушника заходів правового примусу.

Ефективність адміністративно-правових гарантій реалізації правозахисної функції залежить від Конституції України та чинних нормативно-правових актів у сфері захисту прав, свобод і законних інтересів осіб, а також від того, як виконують положення цих законів компетентні правозахисні інституції, що мають створювати умови для реалізації правозахисної функції в Україні.

Аналіз чинного законодавства у сфері захисту прав, свобод і законних інтересів осіб дозволяє стверджувати, що в Україні встановлені правові гарантії реалізації правозахисної функції. Конституція України гарантує державний захист прав, свобод і законних інтересів людини і громадянина і здійснює їх регулювання. Адміністративно-правові гарантії реалізуються діями відповідних правозахисних суб’єктів. Гарантом додержанням прав і свобод індивіда у нашій державі виступає Президент України. Вживати заходи щодо забезпечення прав та свобод людини і громадянина зобов'язаний Кабінет Міністрів України. Відповідно до своїх повноважень та залежно від сфери діяльності також забезпечують реалізацію правозахисної функції держави Верховна Рада України, центральні органи виконавчої влади, органи місцевої влади, Уповноважений Верховної Ради України з прав людини, правоохоронні органи, органи судової влади, різноманітні інституції громадянського суспільства. Однак насправді практична реалізація адміністративно-правових гарантій захисту прав, свобод і законних інтересів людини і громадянина перебуває на низькому рівні.

За результатами соціологічного опитування Центру Разумкова, українці не довіряють компетентним правозахисним інституціям. Так, у п'ятірці лідерів, яким найбільше не довіряють українці, - державний апарат/чиновники (їм не довіряють 83 \%), Верховна Рада України (82 \%), судова система (78 \%), політичні партії (77 \%), Кабінет Міністрів України (75\%). Також високий рівень недовіри громадян мають Президент України (71 \%), прокуратура (70 \%), Верховний Суд України (65 \%), Спеціалізована антикорупційна прокуратура (65 \%), Національне антикорупційне бюро України (64%), Національне агентство з питань запобігання корупції (64 \%), Антикорупційний суд (62 \%), Конституційний Суд (62 \%) та профспілки (58 \%) [17].

Наведені дані опитування свідчать, що необхідні умови для ефективної реалізації правозахисної функції в Україні не створені, а стан адміністративноправового забезпечення діяльності органів публічної влади у сфері захисту прав, свобод і законних інтересів осіб є далекий від ідеального.

DOI (Article): https://doi.org/10.36486/np.2019.2.06

(C) Bilous Viktor, Stasiuk Oksana, 2019 
Адміністративно-правове забезпечення захисту прав, свобод і законних інтересів людини і громадянина відбувається шляхом створення відповідних умов для його реалізації. Такими умовами є адміністративно-правові гарантії, покликані відновити порушене право, усунути перешкоди в його реалізації, усунути реальну загрозу порушення суб’єктивних прав протиправними діями та застосувати до порушника заходи правового примусу. Сучасний стан гарантованості захисту прав, свобод і законних інтересів людини і громадянина дає підстави стверджувати про наявність низки проблем у напрямі реалізації правозахисної функції в Україні. Тому адміністративно-правові гарантії реалізації правозахисної функції потребують оновлення, результатом якого мають бути пропозиції щодо удосконалення системи адміністративно-правових гарантій та розв’язання існуючих у цій сфері проблем.

\section{СПИСОК ВИКОРИСТАНИХ ДЖЕРЕЛ}

1. Словарь иностранных слов. 15-е изд., доп. М.: Русский язык, 1998. 608 с.

2. Словник іншомовних слів / уклад.: С.М. Морозов, Л.М. Шкарапута. К.: Наукова думка, 2000. 680 с. 234 c.

3. Алексеев С.С. Право и перестройка: вопросы, раздумья, прогнозы. М.: Юрид. лит., 1983.

4. Малеин Н.С. Охрана прав личности советским законодательством / отв. ред. А.И. Масляев. М.: Наука, 1985. 165 с.

5. Фрицький О.Ф. Конституційне право України: підручник. К.: Юрінком Інтер, 2003. 536 с.

6. Стахура Б.I. Роль органів державної влади у забезпеченні прав людини і громадянина в демократичному суспільстві: теоретико-правовий вимір: дис. ... канд. юрид. наук: 12.00.01. Львівський державний університет внутрішніх справ. Львів, 2016. 180 с.

7. Патюлин В.A. Государство и личность в СССР (проблемы взаимоотношений). М., 1974. 224 c.

8. Витрук Н.В. Правовой статус личности в СССР. М., 1985. 176 с.

9. Стещенко С.Г. Адміністративне право України: навч. посіб. К.: Атіка, 2007. 624 с.

10. Какимжанов M.T. Соблюдение прав и свобод граждан в деятельности милиции: автореф. дис. ... канд. юрид. наук: 12.00.02. М., 1995. 24 с.

11. Черкасов А.В. Гарантии защиты конституционных прав несовершеннолетних: автореф. дис. ... канд. юрид. наук: 12.00.02. СПб., 2005. 23 с.

12. Личенко I.O. Захист законних інтересів громадян України у сфері власності: адміністративно-правове дослідження: монографія. Львів: Львівський держ. ун-тет внут. справ, 2014. 416 c.

13. Олефіренко Е.О. Адміністративно-правові гарантії реалізації прав і свобод громадян: автореф. дис. ... канд. юрид. наук: 12.00.07. Національна академія ДПС України. Ірпінь, 2006. $20 \mathrm{c}$.

14. Котормус T.I. Поняття та ознаки адміністративно-правових гарантій захисту права власності громадян України в районах проведення антитерористичної операції. Вісник Національного університету “Львівська політехніка”. Юридичні науки. 2017. № 865. C. $249-256$.

15. Миколенко O.M. Сучасний погляд на класифікацію функцій адміністративного права. Правова держава. 2017. № 25. С. 78-82.

16. Фесько Д.С. Административно-правовые гарантии прав граждан и юридических лиц при осуществлении государственного контроля и надзора: природа, понятие и виды. Вестник Нижегородского университета им. Н.И. Лобачевского. Право. 2018. № 3. С. 165-171.

17. Украинцы уже не доверяют практически ни одному госоргану. URL: https://www.capital. ua/ru/news/124548-ukraintsy-uzhe-ne-doveryayut-prakticheski-ni-odnomu-gosorganu (дата звернення: 25.04.2019).

DOI (Article): https://doi.org/10.36486/np.2019.2.06

(C) Bilous Viktor, Stasiuk Oksana, 2019

Issue 2(4.4) 2019

http://naukaipravoohorona.com/ 


\section{REFERENCES}

1. Slovar inostrannykh slov. 15-Ie izd. "Dictionary of foreign words". 15th ed., Ext. M.: Russian language, 1998. 608 p. [in Russian].

2. Slovnyk inshomovnykh sliv. "Dictionary of foreign words" / format: S.M. Morozov, LM Scarup K.: Scientific Opinion, 2000. 680 p. [in Ukrainian].

3. Aleksieiev S.S. (1983) Pravo i perestroyka: voprosy, razdumia, prognozy. "Law and restructuring: questions, thoughts, predictions". M.: Legal. Literature. 234 p. [in Russian].

4. Malein N.S. (1985) Okhrana prav lichnosti sovetskim zakonodatelstvom. "Protection of the rights of the individual by Soviet legislation" / resp. ed. A.I. Maslyaev. M.: Nauka. 165 p. [in Russian].

5. Frytskyi O.F. (2003) Konstytutsiyne pravo Ukrainy: pidruchnyk. "Constitutional Law of Ukraine": Textbook. K.: Yurinkom Inter. 536 p. [in Ukrainian].

6. Stakhura B.I. (2016) Rol orhaniv derzhavnoi vlady u zabezpechenni prav lyudyny i hromadIanIna v demokratychnomu suspilstvi: teoretyko-pravovyi vymir. "The role of public authorities in ensuring human and civil rights in a democratic society: theoretical and legal dimension": diss. Ph. D.: 12.00.01. Lviv State University of Internal Affairs. Lviv. 180 p. [in Ukrainian].

7. Patyulin V.A. (1974) Gosudarstvo i lichnost v SSSR (problemy vzaimootnoshenii). "State and person in the USSR (relationship problems)". M. 224 p. [in Russian].

8. Vitruk N.V. (1985) Pravovoii status lichnosti v SSSR. "The legal status of the individual in the USSR". M. 176 p. [in Russian].

9. Stetsenko S.H. (2007) Administratyvne pravo Ukrainy: navch. posib. "Administrative Law of Ukraine": Teach. Man. K.: Atika. 624 p. [in Ukrainian].

10. Kakimzhanov M. T. (1995) Sobliudeniie prav i svobod grazhdan v deiatelnosti militsii. "Compliance for the rights and freedoms of citizens in the activities of the police: author. dis. Cand. Jurid. Sciences: 12.00.02. M. 24 p. [in Russian].

11. Cherkasov A.V. (2005) Garantii zashchity konstitutsionnykh prav nesovershennoletnikh. "Guarantees of the protection of the constitutional rights of minors": author. dis. Cand. Juridical Sciences: 12.00.02. SPb. 23 p. [in Russian].

12. Lychenko I.O. (2014) Zakhyst zakonnykh interesiv hromadyan Ukrainy u sferi vlasnosti: administratyvno-pravove doslidzhennia. "Protection of legitimate interests of Ukrainian citizens in the sphere of property: administrative-legal research": monograph. Lviv: Lviv State University of Internal Affairs. 416 p. [in Ukrainian].

13. Olefirenko E.O. (2006) Administratyvno-pravovi harantiyi realizatsii prav i svobod hromadian. "Administrative and legal guarantees of realization of the rights and freedoms of citizens": author's abstract. Dis. Candidate Jurid. Sciences: 12.00.07. National Academy of Internal Affairs of Ukraine. Irpin. 20 p. [in Ukrainian].

14. Kotormus T.I. (2017) Ponyattia ta oznaky administratyvno-pravovykh harantii zakhystu prava vlasnosti hromadian Ukrainy v rayonakh provedennia antyterorystychnoi operatsii. "Concepts and signs of administrative and legal guarantees of protection of the property rights of Ukrainian citizens in areas of anti-terrorist operation”. Bulletin of Lviv Polytechnic National University. Law Sciences. No. 865. 249-256 pp. [in Ukrainian].

15. Mykolenko O.M. (2017) Suchasnyi pohliad na klasyfikatsiyu funktsiy administratyvnoho prava. Pravova derzhava. "Modern view on the classification of administrative law functions. Constitutional state". 2017. No. 25. 78-82 pp. [in Ukrainian].

16. Fesko D.S. (2018) Administrativno-pravovyie garantii prav grazhdan i yuridicheskikh lits pri osushchestvlenii gosudarstvennogo kontrolia i nadzora: priroda, poniatie i vidy. "Administrative and legal guarantees of the rights of citizens and legal entities in the implementation of state control and supervision: nature, concept and types”. Bulletin of Nizhny Novgorod University. N.I. Lobachevsky. Right. No. 3. $165-171$ pp. [in Russian].

17. Ukraintsy uzhe ne doveriaiut prakticheski ni odnomu gosorganu. "Ukrainians no longer trust virtually any government agency". URL: https://www.capital.ua/ru/news/124548-ukraintsyuzhe-ne-doveryayut-prakticheski-ni-odnomu-gosorganu (date of application: 25.04.2019) [in Russian].

DOI (Article): https://doi.org/10.36486/np.2019.2.06 
UDC 342.9

\section{Bilous Viktor, \\ Doctor of Juridical Sciences, Full Professor, National Universety of the State Fiscal Service of Ukraine, \\ Irpin, Ukraine, \\ Stasiuk Oksana, \\ Candidate of Juridical Sciences, Postgraduate, State Research Institute MIA Ukraine, Kyiv, Ukraine}

\section{ADMINISTRATIVE AND LEGAL GUARANTEES FOR THE IMPLEMENTATION OF THE HUMAN RIGHTS FUNCTION IN UKRAINE}

The article is devoted to the study of administrative and legal guarantees of the implementation of the state's human rights function.

The essence of legal guarantees is revealed and administrative-legal are highlighted among them. It is argued that administrative and legal guarantees for the protection of the rights, freedoms and legitimate interests of a person and a citizen and administrative and legal guarantees for the protection of the rights, freedoms and legal interests of a person and citizen are separate types of administrative and legal guarantees.

It was stated that the administrative and legal guarantees of the implementation of the human rights protection function are a special type of general category of "administrative and legal guarantees". Proposed by administrative-legal guarantees of realization of human rights function to understand regulated by administrative-legal norms human rights activities of public authorities, aimed at creating the appropriate conditions for the restoration of violated law, elimination of obstacles to its implementation, elimination of the real threat of violation of subjective rights by illegal actions and application to violator of measures of legal coercion. The signs of administrative and legal guarantees of realization of human rights protection function are presented.

It is emphasized that the current state of guarantee of protection of rights, freedoms and legitimate interests of a person and a citizen gives grounds to assert about the presence of a whole range of problems in the direction of realization of human rights protection functions in Ukraine. Therefore, administrative legal guarantees for the implementation of the human rights function need to be updated, the result of which should be proposals for improving the system of administrative and legal guarantees and the solution of existing problems in this area.

Keywords: human rights function, administrative and legal provision, administrative-legal guarantees, administrative-legal relations, human and civil rights and freedoms, public authority.

Отримано 06.06.2019 
UDC 351.741(477)

Kryvolapchyk Volodymyr, Doctor of Juridical Sciences, Professor, Director of the State Research Institute MIA Ukraine, Kyiv, Ukraine, ORCID ID 0000-0001-9449-2242

\section{PREVENTIVE ACTIVITIES OF THE NATIONAL POLICE OF UKRAINE IN THE CURRENT LEGAL SPHERE}

The article investigates the essence and content of legal regulation of the National Police of Ukraine in the direction of prevention. The legal nature of preventive police measures, their practical use and application by the police in order to the prevention, preclusion and suppression offences, their role in ensuring public safety and order in the state, as well as crime counteraction are considered. The author's definitions of the subject matter and concepts of "legal regulation", "preventive policing" and "preventive police accounting" are set out. On the basis of the research it was proposed to introduce amendments and additions to the current legislation of Ukraine.

Keywords: prevention, legal regulation, preventive policing, preventive police accounting, preclusion, offences.

The main feature of the rule of law is the effective legal regulation of social ties. Therefore, interaction with the National Police of Ukraine should be based on the definition of the areas of activity of its bodies, structural subdivisions and officials that ensure the daily democratic regime of these relations on the basis of the rule of law, inviolability of constitutional rights and freedoms of a human being and citizen.

The effectiveness of the preventive police measures of the National Police depends on the improvement of the normative regulation of police activity, the clarity of legal regulations, the existence of a developed system of legislation and relevant bylaws in this area.

O.F. Andriiko, O.M. Bandurka, V.I. Varenka, I.P. Holosnichenko, Ye.V. Dodina, R.A. Kaliuzhnyi, A.P. Kliushnichenko, A.M. Kolodii, A.T. Komzuk, V.V. Kopieichykova, M.V. Koval, A.T. Komziuk, M.V. Korniienko, S.L. Lysenkova, O.V. Nehotchenko, S.V. Petkov, P.M. Rabinovich, Yu.I. Rymarenko, O.F. Skakun, O.D. Tikhomirova, I.M. Shopina, Yu.S. Shemshuchenko V.K. Shkarupa, dedicate their writings to the issues of organization of legal regulation of activities in the state, society, including the bodies of internal affairs and police. Determination of the nature and peculiarities of preventive and coercive police measures carried out by the police was studied by D.M. Bakhrach, Ye.A. Bessmertnyi, H.P. Bondarenko, I.O. Galagan, V.K. Kolpakov, O.P. Korenev, O.M. Lunov, O.P. Sherhin, O.M. Yakuba and other scientists in the field of administrative law. However, the administrative and legal aspects of preventive police measures, despite their theoretical and practical significance and importance, remain undisclosed or debatable. 
The purpose of the article is the analysis of administrative and legal aspects of legal regulation of the National Police of Ukraine in the field of prevention, preventive police measures and preventive police accounting.

Scientific literature has consistently noted the place of law and legal regulation in the organization of any activity of the state and society. In this regard, A.F. Skakun understands legal regulation as the regulation of social relations, their legal consolidation, protection and development, carried out with the help of law and a set of legal means [1,704 p.]. A.T. Kozmyuk notes that legal regulation is a specific impact, which is carried out by law as a special normative institutional regulator. The peculiarity of legal regulation is such a type of social regulation, which has a purposeful, structured, effective character and is carried out through a targeted system of means that realistically reflects the very essence of law as a normative institutional formation - a regulator [2, 408 p.].

Thus, legal regulation is defined as the action of the right to public relations with the help of certain legal means, first of all the norms of law [3, 320 p.]. A.N. Bandurka groundedly notes: "Legal regulation ensures distribution of control and supervision powers between different bodies and services, officials, establishing certain relations between them" [4, 780 p.]. K.F. Skvortsova specifies: "Legal regulation in any spheres of state activity concerns not only the definition of rights and obligations of subjects of legal relations, but also the construction of this system and, finally, the main issues of the organization of the activities of its individual parts" [5, 160 p.]. With such principles in mind, it should be noted that one of the initial stages of legal regulation is the legal norms that constitute the regulatory framework, the core of the legal regulation mechanism.

Having described the definitions of legal regulation, we determine that the concept of legal regulation should be understood as the ordering of social relations, carried out by the state with the help of law and a set of legal means, their legal fixation, protection and development.

The aggregate of methods and receptions, owing to which social relations of a certain type regulated, are methods of legal regulation.

There are three traditional methods of legal regulation: authorization, obligation and prohibition. Consequently, the specified methods of legal regulation correspond to the direct forms of implementation of legal norms: use, execution, compliance.

At the same time, the legal regulation of police activity in Ukraine provides:

Firstly, considering that legal norms are both a means and the main instrument of management of social objects, and at the same time a regulator of police activity, and a set of social norms and procedures of their implementation, which ensure normal functioning and development of systems in accordance with the conditions of their existence. The State, with the help of legal norms, confers certain powers (duties and specific rights) on State authorities and their officials (subjects of police activity), within the limits of powers and in the ways provided for by the Constitution and the laws of Ukraine.

Secondly, the provision of the legislative, executive and judicial branches of government, the Public Prosecutor's Office and in particular the National Police, as one of the enforcement authority. At the same time, the current legislative and

DOI (Article): https://doi.org/10.36486/np.2019.2.07

(C) Kryvolapchuk Volodymyr, 2019 
regulatory regulation of police activity in Ukraine, including the bodies of the National Police, plays an important role, since the effectiveness of legal regulation depends largely on the improvement of its legal framework, clarity of instructions, and the existence of a developed system of legal norms. Legal norms are used to ensure: defining a system of police powers to ensure the implementation of preventive police measures by the police authorities and units; the distribution of functions between the units of a given police authority and their employees for the implementation of preventive police measures; and the consolidation of the system of facilities and objects of police activity of the National Police.

Thirdly, the clarification of the number of public relations that arise, that is to say, the definition of the subject of legal regulation, which covers all public relations, which objectively by their nature can succumb to regulatory and organizational impact and in these socio-political conditions require such an impact, carried out with the help of legal norms and all other legal means.

Fourth, it makes it possible to determine the role of law in the regulation of police activity in Ukraine, carried out with the help of legal norms, which are legally enshrined in: 1) the system of police officers' powers to realize their rights; 2) forms, types, directions and permissible limits of police activity in the implementation of preventive police measures; 3 ) the system of objects and subjects of law enforcement activity of police officers; 4) distribution of supervisory functions between subdivisions of a certain body and their employees; 5) basic parameters of interaction and coordination of the activities of the subjects of police activity in the implementation of preventive police measures; 6 ) legal protection of the interests of the subjects of police cooperation; 7 ) the system of preventive police measures in the interests of ensuring the rule of law, protection of human and civil rights and freedoms, interests of society and the state, as well as stability of public relations.

So far, the bodies of the National Police of Ukraine operate within a certain territory and, accordingly, are reporting and under the control of the executive authorities, primarily the Cabinet of Ministers of Ukraine. The bodies of the National Police of Ukraine, as subjects of police activity, differ in a number of ways. First and foremost, these are the bodies that carry out control and supervision functions; they continuously perform special state powers in relation to the subjects subordinated to them, which are obliged to implement the decisions taken by the bodies of the National Police of Ukraine, within their competence. Thus, we are talking about powers above departmental ones. It is necessary to understand that this body is vertically interconnected, in particular, there are internal subordination relations, as well as control functions in relation to its activities, vested with authoritative powers.

Current police activity in Ukraine is characterized by the following signs:

- is based on the Basic Law and the laws of Ukraine;

- is aimed at objects, the composition of which depends on a specific stage of historical development of the society and political factors;

- Its content in our society is organically connected with law and legal understanding, and it clearly expresses the inextricable link between the state and law, their mutual influence;

- is a public policy;

DOI (Article): https://doi.org/10.36486/np.2019.2.07

(C) Kryvolapchuk Volodymyr, 2019 
- is formed and implemented under the influence of a complex of objective and subjective factors (legal consciousness of a person, citizen and society as a whole, the state of crime, economic development of the state, personnel policy selection and placement), political leadership of the state, its attitude to this issue;

- is implemented through managerial, organizational and legal means and through the use of preventive police measures, as well as the use of State coercive police measures, etc.

At the same time, legal regulation of police activity in Ukraine is contained in legislative and regulatory acts of various forms, nature and legal force.

As a form of existence, legal norms are designed to regulate relations in the area of policing in the direction of prevention, and regulatory instruments are a way of fixation and their action, their place of stay in the social and legal dimension of the national legal system. Through normative and legal acts, the content of legal norms, provisions of law enforcement practice, as well as in most cases individual prescriptions and decisions of individual officials are disclosed.

For instance, according to Article 3 of the Law of Ukraine "On the National Police" dd. 02.07.2015 No. 580-VIII, it is stated that in its activities the police are guided by the Constitution of Ukraine, international treaties of Ukraine, consent to be bound by the Verkhovna Rada of Ukraine, the indicated Law and other laws of Ukraine, acts of the President of Ukraine and resolutions of the Verkhovna Rada of Ukraine adopted in accordance with the Constitution and laws of Ukraine, acts of the Cabinet of Ministers of Ukraine, as well as acts of the Ministry of Internal Affairs of Ukraine issued in accordance with it, and other normative and legal acts [6, 379 p.].

Thus, the legal regulation of the activity of the National Police of Ukraine in the area of prevention is provided by a specially created state mechanism, the main component of which is the existing rules of law laying down in laws and other legal acts, regulated by a significant number of regulatory acts, which differ from each other in many ways: the name, legal force, the order of adoption, entry into force, etc.

Thereby, the legislation of Ukraine in the sphere of legal regulation of the activity of the National Police of Ukraine in the area of prevention is premised on the Basic Law of Ukraine and represents a set of laws, which implement the legal impact of the state on public affairs with the help of legal norms. All legal norms are equally aimed at the ultimate goal, but their content, procedure of establishment and influence on the processes of legal regulation of police activity in the sphere of action and the mechanism of distribution in the legal system are different. The State confers certain powers (duties and specific rights) on the National Police and its officers (subjects of policing), within which they carry out police activities and are guided by the laws of Ukraine, international treaties of Ukraine, the consent to be bound by which is given by the Verkhovna Rada of Ukraine, acts of the President of Ukraine and decisions of the Verkhovna Rada of Ukraine, the legal acts (orders and instructions) of the Ministry of Internal Affairs and the National Police of Ukraine adopted in accordance with the Constitution and the laws of Ukraine, the decisions and instructions of the Cabinet of Ministers of Ukraine, as well as the legal acts (orders and instructions) of the Ministry of Internal Affairs of Ukraine and the National Police of Ukraine issued in accordance with it, and other regulatory and legal acts.

DOI (Article): https://doi.org/10.36486/np.2019.2.07

(C) Kryvolapchuk Volodymyr, 2019 
This being so, the stated gives grounds for the formulation of the concept of "preventive activity" as an activity provided for by the current legislation of Ukraine, aimed at: prevention and is carried out to the formation of illegal intent; prevention and occurs after the formation of illegal intent before the beginning of its implementation and through the commission of an offence, the suppression of offences committed after the beginning of the offence with the possible application of measures to persons, verification of compliance with the requirements established by law, restrictions, as well as with respect to persons on the preventive account. The application of preventive measures by the police complements educational, informational and awareness-raising activities and is based on the principles of legality, necessity, proportionality, effectiveness and respect for human rights and freedoms. Preventive police measures provide for the application of restrictions on certain rights and freedoms in persons and organizations in cases prescribed by law, and this manifests itself as mandatory, although there are no offences against them. That is, these measures have a clear preventive direction, focused on the protection of public safety and order, on the avoidance of offenses. The essence of the prophylactic effect of preventive police measures is, firstly, to avoid unlawful conduct on the part of persons who engage in such conduct, and secondly, to eliminate the causes contributing to the commission of offences and to create conditions precluding unlawful conduct.

In order to ensure the objectives of preventive action, there is a need for preventive police accounting. Such accounting shall be applied to persons who are prone to committing offences and to persons registered with the police to prevention them from committing offences.

The National Police carries out preventive work with persons released from places of deprivation of liberty who have served their sentences for intentional crimes and where the criminal record has not been removed or cancelled in accordance with the procedure established by law, as well as with persons who have been officially warned not to commit domestic violence.

The term "preventive police monitoring" should be understood to mean a series of measures carried out by the unified information system of the Ministry of Internal Affairs of Ukraine, aimed at maintaining proper technical condition of information subsystems on persons on the preventive records and for whom preventive work is carried out by the National Police.

With these matters cleared away, let's summarize that legal regulation is a regulation of social relations carried out by the state with the help of law and a set of legal means, their legal fixation, protection and development. The legal regulation of preventive policing has its own peculiarities. By methods of legal regulation, we understand - a set of methods and techniques by which the community relations of a certain type are ordered.

Relying on the results of the study, we propose to amend Article 30 and Article 31 of the Law of Ukraine No. 580-VIII "On the National Police" dated July 2, 2015 by adding section 2 of Article 30 by paragraph 2 and 3 of the following content:

"Preventive police activity is the activity provided by the current legislation of Ukraine, aimed at prevention, carried out to the formation of illegal intent, avoidance that occurs after formation of illegal intention before the beginning of its realization

DOI (Article): https://doi.org/10.36486/np.2019.2.07

(C) Kryvolapchuk Volodymyr, 2019 
and through commitment of an offence, suppression of the offences made after the beginning of fulfillment of an offence with possible application to persons of measures, check of observance of the requirements established by the law, restrictions, and also concerning persons on the preventive account.

Preventive police accounting is a set of measures implemented by the unified information system of the Ministry of Internal Affairs of Ukraine, which is aimed at maintaining the proper technical condition of the information subsystems of the unified information system of the Ministry of Internal Affairs on persons on the preventive record keeping and for which the National Police are carrying out preventive work".

\section{REFERENCES}

1. Skakun O.F. (2000) Teoriia gosudarstva i prava: uchebnik. "Theory of State and Law": a textbook. Kharkov: Consum. Univ. Intern. Affairs. 704 p. [in Russian].

2. Kozmiuk A.T. (2002) Administratyvnyi prymus v pravookhoronnii diialnosti militsii v Ukraini. "Administrative coercion in law enforcement activities of the police in Ukraine": diss. Ph.D. 12.00.07 Kharkiv. National University of Internal Affairs. Kharkiv. 408 p. [in Ukrainian].

3. Zahalna teoriia derzhavy i prava / za red. V.V. Kopieychykova. "General theory of state and law" / ed. V.V. Kopieichykova Kyiv: Yurinkom, 1997. 320 p. [in Ukrainian].

4. Bandurka O.M. (2004) Teoriia i praktyka upravlinnia orhanamy vnutrishnikh sprav Ukrainy. "Theory and practice of management of internal affairs of Ukraine". Kharkiv. 780 p. [in Ukrainian].

5. Problemy effektivnosti nadzora. "Problems of the effectiveness of supervision" / Ed. K.F. Skvortsova. Moscow: Legal. Lit., 1977. 160 p. [in Russian].

6. Pro Natsionalnu politsiiu. "About the National Police": Act dated July 2, 2015 No. 580VIII. Information from the Verkhovna Rada of Ukraine dated 09.10.2015. $\quad$ No. 40-41. 379 p. [in Ukrainian].

УДК 351.741(477)

Криволапчук Володимир Олексійович, доктор юридичних наук, професор, директор ДНДІ МВС України, м. Київ, Україна, ORCID ID 0000-0001-9449-2242

\section{ПРЕВЕНТИВНА ДІЯЛЬНІСТЬ НАЦІОНАЛЬНОЇ ПОЛІЦЇ̈ УКРАЇНИ В СУЧАСНОМУ ПРАВОВОМУ ПОЛІ}

У статті досліджено сутність і зміст правового регулювання діяльності Національної поліції України за напрямом превенції, яке забезпечується за допомогою спеціально створеного державного механізму, основним елементом якого є норми права, закріплені в законах та інших правових актах, якими визначається модель поведінки суб'єкта суспільних відносин - органу поліції за напрямом превенції.

Розглянуто правову природу превентивних поліцейських заходів, проаналізовані питання їх практичного використання і застосування Національною поліцією України з метою профілактики, запобігання і припинення правопору-

DOI (Article): https://doi.org/10.36486/np.2019.2.07

(C) Kryvolapchuk Volodymyr, 2019 
шень, визначено їх роль у забезпеченні публічної безпеки і порядку в державі, протидії злочинності.

Викладено авторські визначення предмета й поняття правового регулювання як упорядкування суспільних відносин, здійснюваного державою за допомогою права і сукупності правових засобів та їх юридичного закріплення, а також методів правового регулювання як сукупності способів і прийомів, за допомогою яких упорядковуються суспільні відносини визначеного виду.

Крім того, запропоновано авторське визначення поняття “превентивна поліцейська діяльність” як діяльность, передбачена чинним законодавством України, спрямованої на: профілактику та здійснення до формування протиправного умислу; відвернення, що відбувається після сформування протиправного умислу до початку його реалізації і через вчинення правопорушення; припинення правопорушень, здійснених після початку вчинення правопорушення із можливим застосуванням до осіб запобіжних заходів, перевірки дотримання встановлених законом вимог, обмежень, а також стосовно осіб, які перебувають на превентивному обліку. Сформульовано поняття “превентивний поліцейський облік”, яке запропоновано розглядати як комплекс заходів, здійснюваний єдиною інформаційною системою МВС України для забезпечення ефективної роботи інформаційних підсистем обліку осіб, які перебувають на профілактичних обліках та щодо яких здійснюється превентивна робота органами Національної поліції України.

Зважаючи на викладене вище, запропоновано внести зміни та доповнення до ст.ст. 30 та 31 Закону України від 02.07.2015 № 580-VIII “Про Національну поліцію”.

Ключові слова: превенція, правове регулювання, превентивна поліцейська діяльність, превентивний поліцейський облік, профілактика, запобігання, правопорушення.

Отримано 05.06.2019

DOI (Article): https://doi.org/10.36486/np.2019.2.07 Issue 2(4.4) 2019
(C) Kryvolapchuk Volodymyr, 2019 
UDC 351.741(477):316.346.2

\author{
Protsenko Taras, \\ Doctor of Juridical Sciences, Full Professor, \\ Chief Researcher, \\ State Research Institute MIA Ukraine, \\ Kyiv, Ukraine, \\ ORCID ID 0000-0003-0611-5258
}

\title{
FORMING AND IMPLEMENTATION OF GENDER EQUALITY POLICY IN THE SYSTEM OF THE MINISTRY OF INTERNAL AFFAIRS OF UKRAINE
}

The author has researched topical issues of gender equality policy in the system of the Ministry of Internal Affairs of Ukraine. Attention is drawn to the fact that the mechanism for implementing the policy of equal rights and opportunities for women and men in Ukraine is far from being perfect. It was noted that at the current stage of formation and implementation of gender policy in Ukraine should be fixed not only at the national level, but also be specified in various spheres of public life, including law enforcement. The author has submitted proposals to improve the implementation of the policy of equal rights and opportunities for women and men in the system of the Ministry of Internal Affairs of Ukraine.

Keywords: gender equality, law enforcement, equality of rights of men and women.

It is obvious that the implementation of the principle of equality has to cover all life spheres as well as the public one. It is worth noting that today, in Ukraine there are certain preconditions for the implementation of the policy of equal rights and opportunities for women and men (or so-called "gender equality"). At the same time, the mechanism for the implementation of gender equality yet cannot be qualified as perfect. Discrimination against both women and men sexes still exists in Ukrainian society, in particular, in the sphere of exercising the rights to take part in public administration.

In this regard, it is obvious that at the present stage of the formation and implementation of gender policy in Ukraine, the provisions on gender equality should be consolidated not only at the national level but also be detailed in different spheres of public life, including law enforcement one.

Both domestic and foreign scholars devoted a lot of papers concerning the study of individual aspects of the implementation of the policy of equal rights and opportunities of women and men in different time periods. However, there is no comprehensive research related to the introduction of the policy of equal rights and opportunities for women and men directly within the system of the Ministry of Internal Affairs of Ukraine (hereinafter referred to as the MIA). The above information refreshes the need to undertake independent research on this issue and requires follow-up study.

DOI (Article): https://doi.org/10.36486/np.2019.2.08

(C) Protsenko Taras, 2019 
Modern European integration processes taking place in Ukraine, violate socioeconomic and political situation in the country caused fundamental changes in the activities of the majority of state institutions, including law-enforcement agencies. In this context, in the process of implementing Development Strategy of IAA of Ukraine, the MIA was reformed into a multi-functional civilian agency of European type, which ensures guidance and coordination of the activities of the National Police of Ukraine (hereinafter referred to as the NPU), the State Service Emergency Service of Ukraine (hereinafter referred to as the SESU), Administration of the State Border Guard Service of Ukraine (hereinafter the SBGSU), the State Migration Service of Ukraine (hereinafter referred to as the SMSU) and the National Guard of Ukraine (hereinafter referred to as the NGU) implementing the state policy in the relevant spheres by the Cabinet of Ministers (the CMU) by virtue of the Minister of Internal.

Today, it is necessary to consider the activity of the MIA of Ukraine, which is one of the main subjects of the implementation of the mentioned policy, as a perfect example in implementing the policy of the equal rights and opportunities of women and men in government bodies. Thus, a substantive step towards the implementation of the obligations assumed by the state was the establishment of the post of the Adviser on Human Rights and Gender Issues within the Ministry of Internal Affairs in autumn of 2004. The introduction of such a position has become a manifestation of the fact that the MIA can be an active participant in the process of forming and implementing gender policy in Ukraine. In particular, it concerns the issues of the fight against sexual harassment, prevention of domestic violence, child abuse, countertrafficking in persons. Moreover, according to the Order of the MIA as of 06.02.2008 № 105, it was created a working group under the MIA to introduce gender approaches into the activities of IAA. It elaborated Program for Gender Equality in the Internal Affairs Agencies (hereinafter referred to as IAA) in Ukraine for the period until 2011 aimed at developing and maintaining gender equality in the IAA through conducting a complex of measures to resolve problems of law-enforcement bodies [1].

At the same time, it must be noted that statutory regulation of the mentioned sphere does not fully reflect the real state of affairs. In order to assess the current state of introduction of the policy of equal rights and opportunities for women and men in the system of the MIA of Ukraine, in our opinion, the analysis of statistical information on the distribution and the ratio of men and women of the Ministry of Internal Affairs of Ukraine is an important precondition, in particular: the Central Office of the Ministry of Internal Affairs of Ukraine, institutes and establishments subjected to its administration, namely: the Main Service Center, higher education institutions and research establishments (hereinafter referred to as the MIA) as well as the National Guard of Ukraine and central executive bodies the activities of which are guided and coordinated by the CMU through the Minister of Internal Affairs (hereinafter Internal Affairs Agencies) both for 2016-2017 and 2018 (as of August, 2018). The study of this information allows identifying the dynamics of involvement of women and men in the activities of the above-mentioned bodies as well as assessing the success of the introduction of policy on the equal rights and opportunities for women and men in the system of the MIA of Ukraine during the last three years. In addition, obtained data can serve as an informational basis for further adjustments in personnel

DOI (Article): https://doi.org/10.36486/np.2019.2.08

(C) Protsenko Taras, 2019 
policy in the context of introducing gender parity in the system of the MIA of Ukraine [2].

Thus, the analysis of statistic data on general characteristic of personnel policy on recruitment and holding of women and men on the positions in the system of the MIA of Ukraine during 2016-2017 shows that the total number of people working in the system of the MIA of Ukraine (not taking into account the State Border Guard Service of Ukraine and the State Emergency Service of Ukraine due to the lack of data) is as follows:

- in 2016, it was more than 150 thousand people; more than 105 thousand or $69.2 \%$ were men and more than 47 thousand or $\approx 30.8 \%$-women;

- in 2017, it was more than 170 thousand people; more than 118 thousand or $71.3 \%$ were men and more than 47 thousand or $28.7 \%$ - women.

The above data demonstrates the following situation: the total number of employees in 2017 increased by $8.68 \%$ compared to 2016 but it was not caused by the expansion in the number of women. Based on the data, one can conclude that vacancies were mainly held by men, whose number has increased by $2 \%$. If to examine data in individual bodies, it is worth mentioning that the number of working people:

1) in the Central Office of the MIA, higher education institutions and scientific establishments, service centers and other institutions and establishments belonging to the sphere of its management (hereinafter referred to as the MIA):

- in 2016, it amounted to more than 19 thousand people $(\approx 12.62 \%$ of the total number of employees of the MIA) where more than 7 thousand or $39.5 \%$ were men and more than 11 thousand or $60.5 \%$ - women;

- in 2017, the total number of women increased and amounted to more than 12 thousand compared to almost 8 thousand men whose number also increased; women prevailed over the number of men by about a third;

2) in relation to the internal affairs agencies (in particular, the National Guard of Ukraine and central executive bodies the activities of which are guided and coordinated by the Cabinet of Ministers of Ukraine through the Minister of Internal Affairs (except the State Border Guard Service of Ukraine and the State Emergency Service of Ukraine due to the lack of data), in 2016, the total number was more than 133 thousand people ( $\approx 87.3 \%$ of the total number of employees of the MIA) where more than half - more than 98 thousand were men $(\approx 73.4 \%$ of the total number of employees in the system of the MIA of Ukraine) and just more than 35 thousand women $(\approx 26.5 \%$ of the total number of employees in the internal affairs agencies of Ukraine). In its turn, in 2017, the total number of women (executives and performers) was $\approx 36$ thousand $(\approx 24.3 \%)$ compared to more than 110 thousand men $(\approx 75.6 \%)$ and is less than the number of men in three times.

Thus, in comparison with the MIA, there is a lack of the balance in the general amount of staff in the very internal affairs agencies. At the same time, the distribution of women and men by post shows varying nature and traditional hold of executive positions mainly by women, while leadership positions are mostly occupied by men. This tendency is mainly observed in the bodies of the MIA of Ukraine.

The analysis of the obtained statistics does not allow drawing up a coherent vision of the ratio of the number of women and men employees who are on parental

DOI (Article): https://doi.org/10.36486/np.2019.2.08

(C) Protsenko Taras, 2019 
leave due to the lack of such data towards the MIA and the NGU. But nevertheless, the analysis of a similar data concerning the MIA bodies gives the reasons to argue that the situation is as follows.

In 2016, more than $98 \%$ of $100 \%$ of employees, who were on parental leave, of the MIA bodies were women. 3,664 people are the total number of employees of the central executive bodies who had childcare leave in 2017. Almost $100 \%$ of them are women $(97.70 \%)$. In the context of the aforementioned, it is not surprising that in the central office of the National Police of Ukraine none of the male employees took a child-care leave and $100 \%$ of the so-called "parental leave people" were women.

Thus, during 2016-2017, the percentage of women was one-third of the total number of employees in the analysed bodies. Moreover, the distribution of posts showed that most of the positions related to the performance of assignments were occupied by women compared to senior positions where the density of men is significantly higher. The largest gap between the number of men and women was observed in security agencies, where a critical lack of female employees was noted.

As for 2018, it should be noted that the analysis of statistical data on the general characteristics of the personnel policy regarding the employment and posts maintenance for women and men shows that the number of men in the entire system of the MIA of Ukraine exceeds the number of women almost 4.5 times or by $56 \%-78 \%$ of men and $22 \%$ of women of the total number of employees (taking into account the SBGSU and the SMSU) as of 20.08.2018. Thus, the total number of employees in the MIA of Ukraine is more than 290 thousand people: more than 226 thousand are men $(\approx 78 \%$ of the total number) and more than 64 thousand are women $(\approx 22 \%$ of the total number).

Among them the number of employees of:

1) the MIA (the Central Office, the Main Service Center, higher education institutions and scientific establishments of the MIA) is 13 thousand people: more than 6600 or $50.4 \%$ are men and more than 6,500 or $49,6 \%$ are women;

2) the number of employees of the internal affairs agencies (in particular, the National Guard of Ukraine and central executive bodies the activities of which are guided and coordinated by the Cabinet of Ministers of Ukraine through the Minister of internal Affairs) is more than 277 thousand people: more than 220 thousand or $79.3 \%$ are men and more than 57 thousand or $20.7 \%$ are women.

Consequently, it is observed that the MIA keeps gender parity that is approximately the same number of women and men hold posts $(50.4 \%$ of men and $49.6 \%$ of women of the total number of employees in the MIA), while the MIA agencies have a certain misbalance because the amount of men holding posts exceeds 3.8 times or by $58.6 \%$ the amount of women $(79.3 \%$ of men and $20.7 \%$ of women of the total number of employees in the MIA agencies).

The results of gender analysis of the implementation of personnel policy in individual bodies and units of the MIA of Ukraine regarding the recruitment and posts maintenance for women and men gives grounds to state that there is a significant difference in the number of female and male employees. For example, the absence and/or low number of women is usually observed in those agencies and units whose functions and tasks the society mainly associates with men, that is, the implementation

DOI (Article): https://doi.org/10.36486/np.2019.2.08

(C) Protsenko Taras, 2019 
of which requires excellent physical training, involves increased responsibility, heavy physical activity, service in "field conditions" (that, in turn, leads to the lack of appropriate sanitary comfort), frequent absence at home, the need to work in a mode of high exertion and self-denial.

First of all, they include the NGU, SBGSU, NPU and SMSU where the number of women amounts from $7.1 \%$ to $28 \%$ of the total number of these bodies, as well as separate units of the MIA the activities of which are directly related to interaction with these bodies (Office of Cooperation with the NGU, Office of Cooperation with the SBGSU, Office of Cooperation with NPU, division of mobilization work and armor protection organization). In other words, agencies the activities of which are related to the observance of strict hierarchy, subordination and discipline, special organizational structure and interpersonal communication, physical well-being, greater social and professional responsibility, the resolution of operational-service tasks, unlimited work day, and high risk to lose health and/or even life.

In contrast, the absence and/or the low number of men is observed in those bodies and units the functions and tasks of which are mainly related to conditions that require activity without additional physical and psychological stresses with a more calm and normalized work schedule (for example, legal support, documentation of official activity, monitoring of human rights observance, provision of health care, compliance with gender equality, etc.). Thus, such units should be considered, in particular: in the MIA - Department for Gender Equality Issues; Department for the Prevention of Corruption and Lustration; Department of Legal Support; Department of Informatization; Department of Health and Rehabilitation, Department of Official Activity Documentation, Office of Human Rights Monitoring; in the bodies of the MIA - SMSU where the number of women is almost $80 \%$ of the total number of employees of the State Migration Service of Ukraine.

If to conduct a gender analysis of the implementation of personnel policy in the system of the MIA of Ukraine in terms of holding senior positions in the system of the MIA of Ukraine, it should be emphasized that the number of employees who hold leadership positions (not below than deputy head of the department) in the system of the MIA of Ukraine is more than 34 thousand people, among which more than 30 thousand or $87 \%$ are men and more than 4 thousand or just $13 \%$ are women.

The number of employees who hold senior posts directly in:

1) the MIA, there are 1600 thousand people: more than 1100 thousand are men $(\approx 69.7 \%)$ and more than 500 are women $(\approx 30.3 \%)$;

2) there is a misbalance in gender parity towards holding senior posts by men and women in the internal affairs agencies where the number of employees holding senior positions is more than 32 thousand people, among which more than 28 thousand are men $(\approx 87.8 \%)$ and more than 4 thousand are women $(\approx 12.2 \%)$ :

- a small number of women holding leadership positions is observed: in the National Guard of Ukraine where only $2.3 \%$ of women take senior positions and $97.7 \%$ are men; in the State Border Guard Service of Ukraine where only $\approx 10 \%$ of women occupy managerial positions and $\approx 90 \%-$ men; in the National Police of Ukraine where only $\approx 12.5 \%$ of women occupy managerial positions and $\approx 87.5 \%$ is 
men; in the State Emergency Service of Ukraine where $\approx 19.1 \%$ of women hold senior positions and $\approx 80.9 \%$ - men;

- in turn, a large number of women who hold leadership positions is observed only in the State Migration Service of Ukraine where $59 \%$ of women hold senior positions, and $40.9 \%$ is men.

Thus, as you can see, the number of men in the system of the MIA of Ukraine, who hold managerial positions in the system of the MIA of Ukraine, exceeds the number of women almost in 7.6 times or by $74 \%$. The number of men who are hold managerial positions in the Ministry of Internal Affairs of Ukraine exceeds the number of women almost 3.2 times or by $39.4 \%$ and in the agencies of the MIA of Ukraine - exceeds the number of women more than 7 times or by $75.6 \%$.

Gender analysis of the implementation of personnel policy in the system of the MIA of Ukraine regarding the issue of parental leave gives grounds to assert that the number of employees of internal affairs agencies of Ukraine, who were on parental leave, is more than 6200 persons: almost $97 \%$ are women and only about $3 \%$ are men.

It should be pointed out that carrying out comprehensive analysis of employees in individual bodies and units of the MIA of Ukraine, who are on parental leave, in our opinion, is not expedient because the absolute majority of the total staffing (that is more than $90 \%$ ) is women.

In this context, one can mark only the National Guard of Ukraine where the number of women who are on parental leave amounts to $100 \%$ of the total staffing.

I would also like to draw your attention to the fact that there is a significant difference in the ratio of women and men not only regarding holding of management positions and parental leave, as it was mentioned above, but also regarding the participation in the Anti-Terrorist Operation (ATO), Joint Forces Operation (JFO) and peacekeeping activities. The great majority of employees of the system of the MIA of Ukraine who have taken part or participate in ATO (JFO) (including those who were injured /crippled or who died in the ATO zone (JFO) and obtained the status of "Combat veterans") as well as in peacekeeping activities are men.

Thus, the number of female employees in the system of the MIA of Ukraine who have taken part or participate in ATO (JFO) (including those who were injured / crippled or who died in the ATO zone (JFO) and obtained the status of "Combat veterans") as well as in peacekeeping activities is from $0,04 \%$ to $2,8 \%$. The above conclusion is based on the fact that the number of employees in the system of MIA of Ukraine, as of 20.08.2018, who:

1) has participated or is participating in maintaining ATO (JFO) is 47 thousand people, 46 thousand of whom is men $(\approx 97.4 \%)$ and only more than 1100 are women $(\approx 2.5 \%)$, in particular, the number of such employees: a) in the MIA is 555 people, 474 of whom are men $(\approx 81 \%)$ and 81 - women $(\approx 14.6 \%)$; b) in the agencies of the MIA system (not taking into account the data of the State Guarder Board of Ukraine due to the lack of information) it accounts to 46 thousand people, more than 45 thousand of whom are men $(\mathrm{H} \approx 97.6 \%)$ and over 1100 are women $(\approx 2.3 \%)$;

2) was injured /crippled in the ATO zone is 861 people, 852 of whom are men $(\approx 98.9 \%)$ and only 9 women $(\approx 1.04 \%)$, in particular, the number of such employees: a) 11 persons in the MIA, no women at all, and all 11 persons (100\%) are only men;

DOI (Article): https://doi.org/10.36486/np.2019.208

(C) Protsenko Taras, 2019 
b) in the system of the MIA agencies (not taking into account the data of the State Guarder Board of Ukraine due to the lack of information), it is 850 people, 841 of whom are men $(\approx 98.9 \%)$ and more than 9 are women $(\approx 1.09 \%)$;

3 ) died in the ATO zone (JFO): 236 people, 235 of whom are women ( $\approx 99.6 \%)$ and only one woman $(\approx 0.4 \%)$;

4) obtained the status of "Combat veterans": more than 35 thousand people, more than 34 thousand of whom are men $(\approx 97.2 \%)$ and over 900 people are women $(\approx 2.8 \%)$, in particular, the number of such workers: a) in the MIA is 545 people, 483 of whom are men $(\approx 88,6 \%)$ and 62 - women $(\approx 11,4 \%)$; b) in the agencies of the MIA of Ukraine (not taking into account the data of the State Guarder Board of Ukraine due to the lack of information) there are more than 34 thousand people, 33 thousand of whom are men $(\approx 97.4 \%)$ and more than 900 are women $(\approx 2.6 \%)$;

$5)$ involved in peacekeeping activities - 153 people, 148 of whom are men $(\approx 96.7 \%)$ and 4 women $(\approx 2.6 \%)$.

Therefore, the analysis provides grounds for the general conclusion that the current state of introduction of the policy of equal rights and opportunities for women and men in the system of the MIA of Ukraine does not fully comply with the relevant requirements and international standards. Despite the positive changes which have taken place after the MIA reform, there are many gaps in the sphere under consideration, including: a lack of equality between women and men among employees of the MIA system, insufficient security of equal treatment and equal career opportunities for male and female employees and others.

That sort of conclusion is based on the latest statistical data:

1. The number of men in the system of the MIA of Ukraine exceeds the number of women almost 4.5 times or by $56 \%$ ( $78 \%$ of men and $22 \%$ of women of the total number of employees).

2. In the internal affairs agencies of Ukraine, there is a misbalance in the gender parity towards the holding of posts by women and men because men hold the posts 3.8 times or by $58.6 \%$ more than females $(79.3 \%$ of men and $20.7 \%$ of women of the total number of employees in the system of the MIA of Ukraine). At the same time, the MIA observes gender parity, that is, there is approximately equal number of women and men holding posts (50.4\% of men and $49.6 \%$ of women of the total number of employees of the MIA).

3. There is a meaningful and significant difference in the number of female and male employees in separate units of the MIA and internal affairs agencies. For example, the absence and / or a low number of women is usually observed in those agencies and units the functions and tasks of which the society mainly associates with men, that is, the implementation of which requires excellent physical well-being, involves increased responsibility, heavy physical activity, service in "field conditions" (that, in turn, leads to the lack of appropriate sanitary comfort), frequent absence at home, the need to work in a mode of high exertion and self-denial.

They should include agencies the activities of which are related to the observance of strict hierarchy, subordination and discipline, special organizational structure and interpersonal communication, excellent physical well-being, greater social and professional responsibility, the resolution of operational-service tasks, unlimited work day, and a high risk to lose one's health and/or even life.

DOI (Article): https://doi.org/10.36486/np.2019.2.08

(C) Protsenko Taras, 2019 
In contrast, the absence and/or a low number of men is observed in those bodies and units the functions and tasks of which are mainly related to the conditions that require activity without additional physical and psychological stresses with a more calm and normalized work schedule (for example, legal support, documentation of official activity, monitoring of human rights observance, provision of health care, compliance with gender equality, etc.).

4. There is a significant difference in the correlation of women and men not only in the context of holding senior posts in the system of the MIA of Ukraine and parental leave but regarding participation in ATO (JFO) and peacekeeping activity, in particular:

1) now, men hold the majority of senior positions in the system of the MIA of Ukraine. Thus, the number of men in the system of the MIA of Ukraine, who hold senior positions (not below than a deputy head of the department), exceeds almost 7.6 times or by $74 \%$ the number of women $(87 \%$ of men and $13 \%$ of women of the total number of senior employees). The number of men who hold senior positions in the Ministry of Internal Affairs of Ukraine is almost 3.2 times or by $39.4 \%$ higher than the number of women $(69.7 \%$ of men and $30.3 \%$ of women of the total number of senior employees) and in the bodies of the MIA of Ukraine - almost 7.1 times or by $75.6 \%$ higher than the number of women $(87.8 \%$ of men and $12.2 \%$ of women of the total number of senior employees);

2) parental leave among male staff of the system of the MIA of Ukraine is unpopular, and the number of women in the system of the MIA of Ukraine who are on parental leave exceeds the number of men almost 33.3 times or by $94 \%$ (97\% of women and $3 \%$ of men are on parental leave), and in the National Guard of Ukraine none of male employees took a parental leave and $100 \%$ of the so-called "parental leave people" were women;

3 ) the overwhelming majority of employees of the system of the MIA of Ukraine who has participated or are participating in ATO (JFO) (including those who were injured /crippled or who died in the ATO zone (JFO) and obtained the status of "Combat veterans") as well as in peacekeeping activities is men. Thus, the number of female employees in the system of the MIA of Ukraine who has participated or is participating in ATO (JFO) (including those who were injured /crippled or who died in the ATO zone (JFO) and obtained the status of "Combat veterans") as well as in peacekeeping activities is from $0,04 \%$ to $2,8 \%$.

Thus, the findings confirm the availability of significant differences in the number of female and male employees in the relevant bodies and units of the MIA. The phenomena can be explained by the lack of interest in the majority of women to hold the positions requiring excellent physical well-being, involving increased responsibility, heavy physical activity, over time work, etc. giving preference to nonstress areas of work, with standard working hours, without additional workload trying to balance their work life with the family. It is also caused by the fact that now in the system of the MIA there are relevant prejudices that first, women are not ready for such type of work and are not interested in it and, secondly, such positions should be mainly held by the employees who have a certain list of qualities that is usually peculiar to male not female character according to the vision of an ordinary person.

We believe that it was caused by the narrow understanding of gender issues as well as by the availability of certain gender stereotypes which are deeply rooted in the

DOI (Article): https://doi.org/10.36486/np.2019.2.08

(C) Protsenko Taras, 2019 
society according to which: first, work in law enforcement agencies, holding of senior positions in the agencies as well as participation in ATO (JFO) and peacekeeping activity is understood as exclusively man not woman staff; second, it is considered that solely a woman should be engaged in upbringing of children and therefore, it is she who should be on parental leave. One for the reasons is also the existence of certain stereotypes about the fact that one of the reasoning may be the marginalization of father role laid down since the Soviet era when motherhood was considered the greatest duty to the state. It is impossible to disagree with the fact that "... in the security sector, there is a widespread metaphor for women career as follows "three maternity leaves-you are colonel", or "3 maternity leaves - retiring pension". At the same time, men who are on service, taking parental leave, are often publicly or implicitly victimized by colleagues and executive staff, subject to certain mockeries and ridicules because they are not considered to be full-time employees [3]. Many experts believe that the above stereotypes are available due to the corresponding public perception of the social role of a man who is a priori considered to be a courageous "breadwinner" of the family, and one who is on parental leave is a "henpecked husband" who had to stay at home due to his inability to support his family.

\section{REFERENCES}

1. Bidenko Yu., Kyselova V. Pro hendernu polityku v Ukraini. "On gender policy in Ukraine". URL: http://gendercenter.sumdu.edu.ua/ index.php/news/314-pro-hendernu-polityku-v-ukraini (date of application: 18.03.2019) [in Ukrainian].

2. Koller Yu. S. (2018) Ministerstvo vnutrishnikh sprav Ukrainy yak subiekt zabezpechennia realizatsii hendernoi polityky v Ukraini. Realizatsiia hendernoi polityky na suchasnomu etapi rozvytku suspilstva: stan, problemy, perspektyvy: materialy I mizh nar. nauk.-prakt. konf. "Ministry of Internal Affairs of Ukraine as a subject of ensuring the implementation of gender policy in Ukraine, Implementation of gender policy at the present stage of society development: state, problems, prospects". (Khmelnytskyi, April, 25. 2018). P. 146-149 [in Ukrainian].

3. Zhinky. Myr. Bezpeka: Informatsiino-navchalnyi posibnyk z hendernykh aspektiv konfliktiv dlia fakhivtsiv sektoru bezpeky. "Women. Peace. Security: A Gender Conflict Handbook for Security Professionals" / Authors / Kyiv, 2017. 264 p. [in Ukrainian].

УДК 351.741(477):316.346.2

Проценко Тарас Олександрович, доктор юридичних наук, професор, головний науковий співробітник ДНДІ МВС України, м. Київ, Україна, ORCID ID 0000-0003-0611-5258

\section{ФОРМУВАННЯ ТА РЕАЛІЗАЦІЯ ПОЛІТИКИ ГЕНДЕРНОЇ РІВНОСТІ У СИСТЕМІ МВС УКРАЇНИ}

Автором досліджено актуальні питання щодо впровадження політики рівних прав і можливостей жінок та чоловіків у системі МВС України. Акцентовано увагу на тому, що механізм упровадження політики рівних прав і можливостей жінок та чоловіків в Україні не є досконалим, про що свідчить наявність дискримінації осіб як жіночої, так і чоловічої статі. Наголошено, що на сучасному етапі

DOI (Article): https://doi.org/10.36486/np.2019.2.08

(c) Protsenko Taras, 2019 
формування та впровадження гендерної політики в Україні положення щодо рівності чоловіків та жінок мають бути закріплені не лише на загальнодержавному piвні, а й конкретизуватися у різних сферах суспільного життя, у тому числі й у правоохоронній. Зазначено, що попри позитивні зрушення, які відбулися після реформування системи МВС, у сфері впровадження політики рівних прав і можливостей жінок та чоловіків залишилося чимало прогалин, які потребують відповідного удосконалення. Констатовано, що для оцінки сучасного стану впровадження політики рівних прав і можливостей жінок та чоловіків у системі МВС України важливою передумовою виступає проведення аналізу статистичної інформації щодо розподілу та співвідношення працівників чоловічої та жіночої статі системи МВС. На підставі аналізу цієї статистичної інформації зроблено висновок про наявність значної розбіжності в кількості працівників жіночої та чоловічої статі у відповідних органах та підрозділах системи МВС, а також визначені основні причини, що сприяють цьому.

3 метою вдосконалення політики гендерної рівності у системі МВС України запропоновано визначити першочерговими заходами: 1) приведення відомчих нормативно-правових актів МВС у відповідність до Національного плану “Жінки, мир, безпека” (зі змінами, внесеними згідно з розпорядженням КМУ від 05.09.2018 № 637-р), Національного плану дій з ліквідації дискримінації та Державної соціальної програми забезпечення рівних прав та можливостей, зокрема, шляхом затвердження нового Плану заходів МВС з реалізації гендерної політики на період до 2021 р. замість Плану заходів МВС щодо виконання Національного плану “Жінки, мир, безпека”, який має бути визнаним таким, що втратив чинність у зв’язку з тим, що його положення не відповідають зазначеним вище національним документам; 2) затвердження Плану заходів із реалізації Стратегії розвитку органів системи МВС до 2020 р., в якому має бути детально визначено відповідні організаційні механізми впровадження досліджуваної політики; 3) забезпечення рівного ставлення та рівних кар'єрних можливостей для працівників чоловічої і жіночої статі в системі МВС, у тому числі шляхом включення відповідних положень до порядку добору кадрів; 4) проведення відповідних навчань, тренінгів, семінарів, круглих столів, форумів тощо, спрямованих на подолання усталених гендерних уявлень та формування сучасних ліберальних поглядів на роль та місце жінок і чоловіків як у суспільному житті взагалі, так й у діяльності органів системи МВС зокрема; 5) здійснення постійного (щороку) гендерного аналізу виконання кадрової політики щодо найму та утримання на робочих посадах жінок та чоловіків; 6) формування кадрових комісій шляхом включення до них однакової кількості жінок та чоловіків з метою зменшення упередженості при прийнятті кадрових рішень; 7) проведення подальших наукових, зокрема, емпіричних, досліджень щодо впровадження принципу рівної участі жінок та чоловіків у системі МВС України, а також протидії дискримінації за ознакою статі та сексуальних домагань; 8) формування гендерної культури працівників системи МВС України та усунення гендерно-дискримінаційних стереотипів; 9) розширення можливостей поєднання сімейних обов'язків та професійної діяльності як жінками, так і чоловіками тощо.

Ключові слова: гендерна рівність, правоохоронна діяльність, рівність прав чоловіків і жінок.

Отримано 07.06.2019

DOI (Article): https://doi.org/10.36486/np.2019.2.08

(c) Protsenko Taras, 2019 
УДК 336.742

Рядінська Валерія Олександрівна, доктор юридичних наук, професор, завідувач науководослідної лабораторії ДНДІ МВС України, м. Київ, Україна

ORCID ID 0000-0002-2210-5933

Коллер Юрій Сергійович, кандидат юридичних наук, старший науковий співробітник, старший науковий співробітник ДНДІ МВС України м. Київ, Україна

ORCID ID 0000-0002-9848-2348 Діхтяренко Кирило Юрійович, здобувач ДНДІ МВС України м. Київ, Україна

\section{ПОНЯТТЯ МОНЕТАРНИХ МЕТАЛІВ ТА ЇХ СПІВВІДНОШЕННЯ ІЗ КАТЕГОРІЕЮ "БАНКІВСЬКІ МЕТАЛИ"}

У статті розглянуто питання співвідношення понять "монетарні метали" та “банківські метали”. Досліджено законодавство щодо визначення та використання цих понять при правовому регулюванні у банківській сфері. На основі аналізу законодавства визначені ознаки, характерні для монетарних металів та ознаки банківських металів. Визначено, що до монетарних металів на сучасному етапі можна віднести лише монетарне золото. Обгрунтовано, що монетарне золото та банківські метали мають різний правовий режим, тому монетарне золото не відноситься до банківських металів.

Ключові слова: монетарне золото, банківські метали, алоковані рахунки, золотовалютний резерв, Національний банк Украйни.

Нормативне визначення монетарних металів в Україні на сьогодні відсутнє, проте таке становище було не завжди. На початку 2000-х років законодавство України містило непоодинокі та неоднозначні визначення монетарних металів. В банківській сфері, відповідно до розпорядження Національного банку України від 29.05.1998 № 208-р “Про нові ціни на монетарні метали”, монетарні метали визначалися як “...зливки (порошки) дорогоцінних металів, які відповідають державним та світовим стандартам якості (Au - не нижче 99,5 \%; Pt - не нижче 99,95\%; Pd - не нижче 99,95 \%) [1]. Цей нормативний акт втратив чинність на підставі розпорядження Національного банку України від 19.01.2001 № 20 "Про затвердження цін на дорогоцінні метали”, в якому термін "монетарні метали" не використовувався, а застосовувалося поняття “банківські метали” [2].

У сфері митного регулювання термін “монетарні метали” отримав власний розвиток. Спочатку визначення монетарних металів містилося в наказі Митної служби України від 27.03.2000 № 164 “Про затвердження Порядку нарахування

(c) Riadinska Valeriia, Koller Yurii, Dikhtiarenko Kyrylo, 2019

DOI (Article): https://doi.org/10.36486/np.2019.2.09 
митних зборів, мита, податку на додану вартість та акцизного збору при митному оформленні товарів, транспортних засобів та запасних частин до них, які переміщуються через митний кордон України і належать громадянам” як “...золото і метали іридієво-платинової групи в будь-якому вигляді і стані, за винятком ювелірних, промислових і побутових виробів з цих металів і брухту цих металів” [3]. Але зазначений вище наказ втратив чинність відповідно до наказу Митної служби України від 12.01.2006 № 5 “Про затвердження Порядку справляння мита, податку на додану вартість і акцизного податку при митному оформленні товарів і транспортних засобів, що переміщуються громадянами через митний кордон України”, в якому визначення монетарних металів вже не надавалося [4]. Цей наказ втратив чинність на підставі наказу Міністерства фінансів України від 22.05.2012 № 581 "Про затвердження Порядку справляння митних платежів при ввезенні на митну територію України товарів громадянами”, який також не містить визначення зазначеного терміна [5].

У сфері валютного регулювання визначення монетарних металів містилося в Декреті Кабінету Міністрів України від 19.02.1993 № 15-93 “Про систему валютного регулювання і валютного контролю”, згідно з нормами якого до монетарних металів відносилися золото і метали іридієво-платинової групи в будь-якому вигляді та стані за винятком ювелірних, промислових і побутових виробів з цих металів і брухту цих металів [6], проте Законом України від 14.07.1999 № 932-XIV "Про внесення змін до деяких законодавчих актів України щодо державного регулювання обігу дорогоцінних металів і дорогоцінного каміння" слова "монетарні метали” у Декреті було замінено словами “банківські метали” у відповідних відмінках, а поняття "монетарні метали” було замінено поняттям “банківські метали” (ст. 2) [7]. Не використовує термін "монетарні метали” і новий Закон України від 21.06.2018 № 2473-VIII “Про валюту і валютні операції”, який був прийнятий після скасування Декрету [8].

Аналіз планомірних змін, що відбулися у законодавстві, підштовхує зробити висновок, що термін “монетарні метали” було замінено поняттям “банківські метали”, проте Закон України “Про Національний банк України” оперує як поняттям “банківські метали”, так і “монетарні метали”. У п. 2 ч. 2 ст. 48 цього Закону зазначається, що використання золотовалютного резерву здійснюється Національним банком на такі цілі, як витрати по операціях з іноземною валютою, монетарними металами, а також іншими міжнародно визнаними резервними активами та операціями із забезпечення діяльності Національного банку в межах сум, передбачених кошторисом адміністративних витрат Національного банку [9]. Отже, метою нашої статті є дослідження поняття “монетарні метали” та їх співвідношення 3 категорією “банківські метали”.

Відповідно до ст. 1 Закону України від 20.05.1999 № 679-XIV “Про Національний банк України”, банківські метали (англ. banking (precious) metals) - це золото, срібло, платина, метали платинової групи, доведені (афіновані) до найвищих проб відповідно до світових стандартів, у зливках і порошках, що мають сертифікат якості, а також монети, вироблені з дорогоцінних металів [9]. Таким же чином банківські метали визначаються і в Законі України від 18.11.1997 № 637/97-ВР “Про державне регулювання видобутку, виробництва і використання дорогоцінних

(C) Riadinska Valeriia, Koller Yurii, Dikhtiarenko Kyrylo, 2019

DOI (Article): https://doi.org/10.36486/np.2019.2.09 
металів і дорогоцінного каміння та контроль за операціями з ними” [10], і в Митному кодексі України [11]. У такому ж значенні визначення банківських металів закріплювалося і в нормативних актах, які на сьогодні втратили чинність: в Декреті Кабінету Міністрів України від 19.02.1993 № 15-93 “Про систему валютного регулювання і валютного контролю” [6], постанові Національного банку України від 06.08.2003 № 325 “Про затвердження Положення про здійснення операцій 3 банківськими металами та внесення змін до деяких нормативно-правових актів НБУ” [12], постанові Національного банку України від 03.12.2003 № 520 “Про затвердження Інструкції з організації перевезення валютних цінностей та інкасації коштів в установах банків" [13], постанові Національного банку України від 15.12.2004 № 644 “Про затвердження змін до Інструкції з організації перевезення валютних цінностей та інкасації коштів в установах банків” [14]; постанові Національного банку України від 01.02.2007 № 45 “Про затвердження Інструкції з організації інкасації коштів та перевезення валютних цінностей у банківських установах в Україні” [15]; постанові правління Національного банку України від 27.05.2008 № 148 “Про переміщення готівки і банківських металів через митний кордон України” [16].

3 огляду на визначення, надане законодавцем, виникає питання щодо того, які ж світові стандарти встановлено для банківських металів? Міжнародні стандарти якості для банківських металів встановлено Лондонською асоціацією ринку дорогоцінних металів (LBMA) і учасниками Лондонського ринку платини і паладію (LPPM), які на національному рівні в Україні затверджені ДЕСТом 28058 “Золото у зливках. Технічні умови” [17], ДЕСТом 28595 “Срібло у зливках. Технічні умови” [18], ДЕСТом 12341-81 “Платина у зливках. Технічні умови” [19], ДЕСТом 12340-81 “Палладій у зливках. Технічні умови” [20] і містять такі вимоги: 1) для зливків золота: маса - від 350 до 450 тройських унцій (від 10886 до 13754 г), вага кожного зливка має бути виражена у тройських унціях і бути кратною 0,025 унції, чистота металу - щонайменше 995 часток хімічно чистого золота на 1000 часток лігатурної маси; обов'язково на зливку зазначається серійний номер, проба, клеймо виробника, рік виготовлення; 2) для зливків срібла: маса зливка - від 500 до 1250 тройських унцій (від 15552 до 38879 г), вага кожного зливка має бути виражена в тройських унціях і бути кратною 0,10 унції; чистота металу - щонайменше 999 часток хімічно чистого срібла на 1000 часток лігатурної маси; обов'язково на зливку зазначається серійний номер, проба, клеймо виробника, вага в тройських унціях або кілограмах (вага зливка у кілограмах має бути переведена у тройські унції і відповідати вказаним вище вимогам); 3) для зливків платини і паладію: маса - від 32,150 до 192,904 тройських унцій (від 1000 до 6000 г); чистота металу - щонайменше 999,5 часток хімічно чистого дорогоцінного металу на 1000 часток лігатурної маси; обов’язкові відмітки на зливку - серійний номер, проба, літери PT або PLATINUM, PD або PALADIUM, клеймо виробника, вага в тройських унціях або грамах; 4) для мірних зливків: зливки банківських металів масою 1 кг і менше, проба яких становить не менше 999,9 для золота, 999 - для срібла, 999,5 - для платини і паладію; 4) для порошків: порошкоподібна субстанція з вмістом хімічно чистого основного дорогоцінного металу для золота - не менше 99,99 \%, для срібла - не менше 99,9 \%, для платини - не менше 99,95 \% лігатурної

( Riadinska Valeriia, Koller Yurii, Dikhtiarenko Kyrylo, 2019 DOI (Article): https://doi.org/10.36486/np.2019.2.09 
маси порошку, що упаковані в скляні ампули або пластмасові банки з маркуванням визнаного виробника [21, с. 103]. Отже, вимоги, що встановлюються: 1) до зливків: а) встановлена вага; б) чистота металу; в) обов’язкові відмітки на зливку; 2) до порошків: а) вміст хімічно чистого основного дорогоцінного металу; б) упаковка в скляні ампули або пластмасові банки; в) маркування визнаним виробником. Крім цього, необхідно наголосити, що, відповідно до п. 4 ч. 1 ст. 1 Закону України від 21.06.2018 № 2473-VIII “Про валюту і валютні операції”, банківські метали входять до складу валютних цінностей [8].

Отже, банківські метали - це дорогоцінні метали, представлені у зливках, порошках, доведених (афінованих) до найвищих проб відповідно до світових стандартів, що мають сертифікат якості, та монетах, вироблених із дорогоцінних металів, які входять до складу валютних цінностей.

Визначення монетарних металів у законодавстві, як зазначалося раніше, не міститься. У словниках слово “монетарні” визначається по-різному: 1) від $\phi p$. моnétaire; лат. monēta - монета; грошові, фінансові [22, с. 277]; 2) фінанси, що відносяться до грошей чи грошового обігу [23, с. 477]; 3) метали, що можуть виступати як фінансові активи [24, с. 528]; 4) що мають фіксовану грошову вартість [25, с. 398]. Етимологічно слово “монетарні” походить від слова “монета". Історично склалося, що упродовж тривалого часу, коли монети складали матеріальну основу грошового обігу, їх виготовляли з різних дорогоцінних металів (золота, срібла, платини) різної якості (високопробного золота $(99,9 \%)$, дукатного золота (98,5 \%), червоного золота (90 \% зі сплавом міді), пістольного золота $(90,6 \%$ золота), білого золота (від 16 до 69 \% зі сплавом срібла)) тощо. Проте на сучасному етапі монети виготовляються не лише з дорогоцінних металів (як наприклад, інвестиційні монети виготовляються з золота найвищої проби), а й з інших видів металів - акмонітала, алюмінію, сталі, нікелю, іридію, мельхіору, олова тощо, проте зазначені метали ні до дорогоцінних, ні тим більше до монетарних не відносяться. Отже, виготовлення монет як ознака, за якою метали відносяться до монетарних, на сьогодні не може використовуватися.

M.О. Гегіна вважає, що лігатурна маса та хімічна чистота металу є ознакою, що дозволяє визначити монетарність дорогоцінного металу. Не випадково, вважає авторка, всі країни встановлюють вимоги щодо визначення найвищої проби монетарного металу (кількості масових часток хімічно чистого дорогоцінного металу на одну тисячу масових часток його лігатури, тобто сплаву), що досягається шляхом афінажу [26, с. 214]. Не можна беззаперечно погоджуватися з цією думкою, оскільки найвища проба дорогоцінного металу - вимога, що встановлюється і для банківських металів, отже, монетарні метали, як і банківські, мають бути афіновані до найвищої проби відповідно до світових стандартів, якою є проба 999.9 кількості масових часток хімічно чистого золота на одну тисячу масових часток його лігатури. Тобто, формальні ознаки (вимоги щодо форми, проби, маркування виробниками тощо) до монетарних металів і банківських металів збігаються.

Для продовження дослідження співвідношення монетарних та банківських металів необхідно визначити, які ж із дорогоцінних металів відносяться до монетарних. Аналіз законодавства (розпорядження Національного банку України

(c) Riadinska Valeriia, Koller Yurii, Dikhtiarenko Kyrylo, 2019 DOI (Article): https://doi.org/10.36486/np.2019.2.09 
від 29.05.1998 № 208-р “Про нові ціни на монетарні метали” [1], наказу Митної служби України від 27.03.2000 № 164 “Про затвердження Порядку нарахування митних зборів, мита, податку на додану вартість та акцизного збору при митному оформленні товарів, транспортних засобів та запасних частин до них, які переміщуються через митний кордон України і належить громадянам” [3], Декрету Кабінету Міністрів України від 19.02.1993 № 15-93 “Про систему валютного регулювання і валютного контролю” [6]) переконує, що в різні періоди національне законодавство відносило до монетарних металів платину, паладій, срібло, метали іридієво-платинової групи в будь-якому вигляді і стані, за винятком ювелірних, промислових і побутових виробів з цих металів і брухту цих металів, проте на сучасному етапі всі вони втратили значення як монетарні. Відповідно до ст. 47 Закону України “Про Національний банк України”, монетарним металом визнається виключно монетарне золото [47]. Тобто, єдиним металом, який на сьогодні має статус монетарного, є золото. Таким чином, до монетарних металів на сучасному етапі відноситься лише монетарне золото. Отже, необхідно визначити, що представляє собою цей вид дорогоцінних металів.

Закон "Про Національний банк України" визначення поняття монетарного золота не надає, закріплює лише те, що воно віднесене до активів, включених до золотовалютного резерву [9]. Таким же чином визначається монетарне золото у Положенні Національного банку України від 26.04.2018 № 229-рш “Про затвердження Положення про політику управління міжнародними (золотовалютними) резервами України" [27]. Не міститься визначення монетарного золота і в інших нормативних актах. У п. 12 ст. 1 Закону України від 18.11.1997 № 637/97-ВР "Про державне регулювання видобутку, виробництва і використання дорогоцінних металів і дорогоцінного каміння та контроль за операціями з ними” вказується, що частину державних золотовалютних резервів України складає афіноване золото у зливках, яке є державною власністю і створює золотий запас України [10]. Отже, на підставі аналізу національного законодавства, можна зробити висновок, що монетарне золото - це афіноване золото (доведене до найвищої, 999, 9 проби) у зливках. Такого ж висновку доходить М.В. Старинський, який на підставі аналізу нормативних актів вказує, що під монетарним золотом слід розуміти золото у зливках, доведене до відповідного світового стандарту, яке є частиною золотовалютних резервів України [28, с. 187]. Автор визначає такі його основні ознаки: 1) є дорогоцінним металом; 2) є валютною цінністю; 3) є банківським металом; 4) є міжнародним резервним активом; 5) зливкова форма; 6) встановлюється спеціальний правовий режим [28, с. 188], тобто науковець ототожнює банківські та монетарні метали.

В інших наукових роботах монетарне золото визначається як таке, що зберігається органами державної влади в якості фінансового активу [29; 30, с. 214; 31, с. 95]. I.I. Кучеров монетарне золото визначає як виготовлений з дорогоцінного афінованого металу предмет, що має вид стандартного зливку чи монети, який слугує цінністю державного золотого запасу чи зберігається в авуарах міжнародної фінансової організації [32]. Ця думка підтверджується нормами міжнародних правових актів. Так, у Класифікаторі фінансових активів монетарне золото визначається як таке, що належить органам грошово-кредитного регулювання, та

(c) Riadinska Valeriia, Koller Yurii, Dikhtiarenko Kyrylo, 2019

DOI (Article): https://doi.org/10.36486/np.2019.2.09 
зберігається ними як резервний актив, а також золото, що утримується міжнародними фінансовими організаціями, яке складається із афінованого золота у вигляді зливків і монет, що зберігається на алокірованих рахунках, та золота, розміщеного на неалокірованих золотих рахунках у нерезидентів, які передбачають право вимагати поставки золота [33]. Алокірований рахунок (англ. allocated account) $€$ різновидом металевих рахунків. Відповідно до ст. 1 Закону України "Про Національний банк України”, металеві рахунки - це рахунки, які відкриваються уповноваженими банками України для обліку операцій, що здійснюються 3 банківськими металами [9]. Алокірований металевий рахунок представляє собою рахунок для обліку дорогоцінних металів, переданих на відповідальне зберігання в банк зі збереженням індивідуальних ознак (найменування, кількості, проби, виробника, серійного номера тощо) [34, с. 276]. Отже, алокірований золотий рахунок представляє собою рахунок, відкритий для обліку операцій, переданого на відповідальне зберігання в банк золота зі збереженням його індивідуальних ознак (найменування, кількості, проби, виробника, серійного номера тощо), а неалокірований - рахунок, відкритий для обліку операцій, переданого на відповідальне зберігання в банк золота без індивідуальних ознак.

Зважаючи на зазначене вище, констатуємо, що монетарним золотом є афіноване до найвищої проби відповідно до світового стандарту золото у зливках та монетах, а також золото, розміщене на алокірованих та неалокірованих золотих рахунках у нерезидентів, які передбачають право вимагати поставки золота.

На наше переконання, монетарне золото не відноситься до банківських металів, оскільки зазначені види металів мають різний правовий режим; монетарне золото є виключною власністю держави, тоді як банківські метали можуть належати на правах приватної власності банкам, суб'єктам господарювання та фізичним особам; Національний банк України виступає розпорядником монетарного золота, але не є його власником, проте операції з банківськими металами можуть здійснюватися виключно його власниками; монетарне золото є активом золотовалютного резерву; відносно монетарного золота та банківських металів встановлюється різний порядок формування, зберігання та використання.

\section{СПИСОК ВИКОРИСТАНИХ ДЖЕРЕЛ}

1. Про нові ціни на монетарні метали: розпорядження НБУ від 29.05.1998 № 208-p. URL: https://zakon.rada.gov.ua/laws/show/v0208500-98?lang=uk (дата звернення: 04.04.2019).

2. Про затвердження цін на дорогоцінні метали: розпорядження НБУ від 19.01.2001 № 20. URL: https://zakon.rada.gov.ua/laws/show/v0020500-01 (дата звернення: 04.04.2019).

3. Про затвердження Порядку нарахування митних зборів, мита, податку на додану вартість та акцизного збору при митному оформленні товарів, транспортних засобів та запасних частин до них, які переміщуються через митний кордон України і належать громадянам: наказ Митної служби України від 27.03.2000 № 164. URL: https://zakon.rada.gov.ua/laws/show/z0227-00/ ed20060408/find?text=\%CC\%EE\%ED\%E5\%F2\%E0\%F0\%ED\%B3+\%EC\%E5\%F2\%E0\%EB\%E8 (дата звернення: 04.04.2019).

4. Про затвердження Порядку справляння мита, податку на додану вартість і акцизного податку при митному оформленні товарів і транспортних засобів, що перемішуються громадянами через митний кордон України: наказ Митної служби України від 12.01.2006 № 5. URL: https:// zakon.rada.gov.ua/laws/show/z0081-06 (дата звернення: 04.04.2019).

5. Про затвердження Порядку справляння митних платежів при ввезенні на митну територію України товарів громадянами: наказ Міністерства Фінансів України від 22.05.2012 № 581. URL: https://zakon.rada.gov.ua/laws/show/z0916-12 (дата звернення: 04.04.2019).

(c) Riadinska Valeriia, Koller Yurii, Dikhtiarenko Kyrylo, 2019

DOI (Article): https://doi.org/10.36486/np.2019.2.09

Issue 2(44) 2019

http://naukaipravoohorona.com/ 
6. Про систему валютного регулювання і валютного контролю: Декрет Кабінету Міністрів України від 19.02.1993 № 15-93.

7. Про внесення змін до деяких законодавчих актів України щодо державного регулювання обігу дорогоцінних металів і дорогоцінного каміння: Закон України від 14.07.1999 № 932-XIV. URL: http://sfs.gov.ua/arhiv/podatkova-baza-do-nabrannya-chinnosti-podatkovim-kodeksom/ normativno-pravova-baza/zakoni-ukraini/arhiv-zakoniv-ukraini/zakoni-ukraini-za-1999-rik/print60492.html (дата звернення: 04.04.2019).

8. Про валюту та валютні операції: Закон України від 21.06.2018 № 2473-VIII. Відомості Верховної Ради. 2018. № 30. Ст. 239.

9. Про Національний банк України: Закон України від 20.05.1999 № 679-XIV. Відомості Верховної Ради України. 1999. № 29. Ст. 238.

10. Про державне регулювання видобутку, виробництва і використання дорогоцінних металів і дорогоцінного каміння та контроль за операціями з ними : Закон України від 18.11.1997 № 637/97-ВР. Відомості Верховної Ради України. 1998. № 9. Ст. 34. Ст. 552

11. Митний кодекс України. Відомості Верховної Ради України (ВВР). 2012. № 44-48.

12. Про затвердження Положення про здійснення операцій з банківськими металами та внесення змін до деяких нормативно-правових актів Національного банку України: постанова Національного банку України від 06.08.2003 № 325.

13. Про затвердження Інструкції з організації перевезення валютних цінностей та інкасації коштів в установах банків: постанова НБУ від 03.12.2003 № 520. URL: https://zakon.rada.gov.ua/ laws/show/z0033-04/ed20070402/find?text=\%C1\%E0\%ED\%EA\%B3\%E2\%F1\%FC\%EA\%B3+ \%ЕС\%Е5\%F2\%Е0\%ЕВ\%Е8 (дата звернення: 04.04.2019).

14. Про затвердження змін до Інструкції з організації перевезення валютних цінностей та інкасації коштів в установах банків: постанова НБУ від 15.12.2004 № 644. URL: https:// zakon.rada.gov.ua/laws/show/z0033-05/ed20070402/find?text=\%C1\%E0\%ED\%EA\%B3\% E2\%F1\%FC\%ЕA\%B3+\%ЕC\%Е5\%F2\%Е0\%ЕB\%Е8 (дата звернення: 04.04.2019).

15. Про затвердження Інструкції з організації інкасації коштів та перевезення валютних цінностей у банківських установах в Україні: постанова НБУ від 01.02.2007 № 45. URL: https:/ /zakon.rada.gov.ua/laws/show/z0181-07/ed20130901/find?text=\%C1\%E0\%ED\%EA\%B3\% E2\%F1\%FC\%ЕA\%B3+\%ЕC\%Е5\%F2\%Е0\%ЕB\%Е8 (дата звернення: 04.04.2019).

16. Про переміщення готівки і банківських металів через митний кордон України: постанова НБУ від 27.05.2008 № 148. URL: https://zakon.rada.gov.ua/laws/show/z0520-08/ed20130607/ find?text=\%C1\%E0\%ED\%EA\%B3\%E2\%F1\%FC\%EA\%B3+\%EC\%E5\%F2\%E0\%ЕB\%Е8 (дата звернення: 04.04.2019).

17. ДСТУ 28058. Золото у зливках. Технічні умови. URL: http://docs.cntd.ru/document/ gost-28058-89 (дата звернення: 04.04.2019).

18. ДСТУ 28595. Срібло у зливках. Технічні умови. URL: https://www.internet-law.ru/ gosts/gost/4215/ (дата звернення: 04.04.2019).

19. ДСТУ 12341-81 Платина у зливках. Технічні умови.

20. ДСТУ 12340-81 Палладій у зливках. Технічні умови. URL: http://gostexpert.ru/gost/ gost-12340-81 (дата звернення: 04.04.2019).

21. Диба М.I., Василенко В.В. Класифікація та функції банківських металів: зб. наук. праць Нац. ун-ту держ. податкової служби України. 2012. № 1. С. 101-110.

22. Исторический словарь галлицизмов русского языка. М.: Словарное издательство ЭТС.

23. Етимологічний словник української мови: у 7 т. / редкол. О.С. Мельничук (гол. ред.)

та ін. К.: Наук. думка, 1983. Т. 5: Р-Т. Уклад.: Р.В. Болдирєв та ін. 2006. 704 с.

24. Морфемно-орфографический словарь. М.: АСТ. Тихонов А. Н. . 2002.

25. Большая советская энциклопедия: у 30 т. гл. ред. А.М. Прохоров. 3-е изд. М.: Советская энциклопедия, 1969-1978.

26. Гегина М.А. Драгоценные металлы и инвестиционный спрос. Деньги и кредит. 2009. № 3. C. 214-221.

27. Про затвердження Положення про політику управління міжнародними (золотовалютними) резервами України: положення НБУ від 26.04.2018 № 229-pш. URL: https://zakon.rada.gov.ua/laws/show/vr229500-18?lang=en (дата звернення: 04.04.2019).

28. Старинський М.В. Правовий режим золота як об'єкта валютних правовідносин. Науковий вісник Ужгородського нац. ун-ту. 2014. Серія “Право”. Вип. 27. Т. 2. С. 187-193.

() Riadinska Valeriia, Koller Yurii, Dikhtiarenko Kyrylo, 2019

DOI (Article): https://doi.org/10.36486/np.2019.2.09 
29. Кучеров И.И. Монетарные металлы и тезаврация. Деньги и кредит. 2016. № 3. С. $212-$ 221. URL. http://www.old.fa.ru/dep/press/about-us/Pages/Monetarnye-metally-i-tezavratsiya.aspx (дата звернення: 04.04.2019).

30. Гегина М.А. Драгоценные металлы и инвестиционный спрос. Деньги и кредит. 2009. № 3. C. 214-221.

31. Зинковский М.A. Драгоценные металлы как объекты банковских сделок. Юридическая работа в кредитной организации. 2012. № 4. С. 87-98.

32. Кучеров И.И. Монетарные металлы и тезаврація. Деньги и кредит. 2016. № 3. С. 212221. URL: http://www.old.fa.ru/dep/press/about-us/Pages/Monetarnye-metally-i-tezavratsiya.aspx (дата звернення: 04.04.2019).

33. Єфремова К.В. Особливості правового регулювання господарської діяльності на ринку виробів із дорогоцінних металів і дорогоцінного каміння: автореф. дис. ... канд. юрид. наук. X ., 2009. 20 c.

34. Райзберг Б.А. Современный социоэкономический словарь. М., 2012, С. 276.

\section{REFERENCES}

1. Pro novi tsiny na monetarni metaly. "On new prices for monetary metals": NBU order dated May 29, 1998, No. 208-p. URL: https://zakon.rada.gov.ua/laws/show/v0208500-98?lang=en (date of application: 04.04.2019) [in Ukrainian].

2. Pro zatverdzhennia tsin na dorohotsinni metaly. "On approval of prices for precious metals": NBU order No. 20 of January 19, 2001. URL: https://zakon.rada.gov.ua/laws/show/v0020500-01 (date of application: 04.04.2019) [in Ukrainian].

3. Pro zatverdzhennia Poriadku narakhuvannia mytnykh zboriv, myta, podatku na dodanu vartist ta aktsyznoho zboru pry mytnomu oformlenni tovariv, transportnykh zasobiv ta zapasnykh chastyn do nykh, yaki peremishchuyutsia cherez mytnyi kordon Ukrainy i nalezhyt hromadianam. "On approval of the Procedure for the calculation of customs duties, duties, value added tax and excise duty upon customs clearance of goods, vehicles and spare parts for them, which are transported through the customs border of Ukraine and owned by citizens": the Order of the Customs Service of Ukraine of 27.03.2000 No. 164. URL: https://zakon.rada.gov.ua/laws/show/z0227-00/ed20060408/ find?text=\%CC\%EE\%ED\%E5\%F2\%E0\%F0\%ED\%B3+\%EE\%E5 \% F2\% E0\% EB\% E8 (date of application: 04.04.2019) [in Ukrainian].

4. Pro zatverdzhennia Poryadku spravliannia myta, podatku na dodanu vartist i aktsyznoho podatku pry mytnomu oformlenni tovariv i transportnykh zasobiv, shcho peremishchuiutsia hromadianamy cherez mytnyy kordon Ukrainy. "On approval of the Procedure for collecting duties, value added tax and excise tax on the customs clearance of goods and vehicles transported by citizens through the customs border of Ukraine: the order of the Customs Service of Ukraine dated January 12, 2006, No. 5. URL: https: //zakon.rada. gov.ua/laws/show/z0081-06 (date of application: 04.04.2019) [in Ukrainian].

5. Pro zatverdzhennia Poryadku spravliannia mytnykh platezhiv pry vvezenni na mytnu terytoriyu Ukrainy tovariv hromadianamy. "On Approval of the Procedure for the Collection of Customs Duties upon Importing Goods by Citizens to the Customs Territory of Ukraine”: Order of the Ministry of Finance of Ukraine dated May 22, 2012 No. 581. URL: https://zakon.rada.gov.ua/laws/show/z091612 (date of application: 04.04.2019) [in Ukrainian].

6. Pro systemu valiutnoho rehuliuvannia i valiutnoho kontroliu. "About the system of currency regulation and currency control: Decree of the Cabinet of Ministers of Ukraine dated February 19, 1993 No. 15-93 [in Ukrainian].

7. Pro vnesennia zmin do deiakykh zakonodavchykh aktiv Ukrainy shchodo derzhavnoho rehuliuvannia obihu dorohotsinnykh metaliv i dorohotsinnoho kaminnia. "On Amending Certain Legislative Acts of Ukraine Regarding State Regulation of Circulation of Precious Metals and Precious Stones": Law of Ukraine of 14.07.1999 No. 932-XIV. URL: http://sfs.gov.ua/arhiv/podatkovabaza-do-nabrannya-chinnosti-podatkovim-kodeksom/normativno-pravova-baza/zakoni-ukraini/arhivzakoniv-krainian/zakoni-ukraini-za- 1999-rik / print-60492.html (date of application: 04.04.2019) [in Ukrainian].

8. Pro valiutu ta valiutni operatsii. "On Currency and Currency Transactions": Law of Ukraine dated June 21, 2018 No. 2473-VIII. Information from the Verkhovna Rada. 2018. No. 30 . Art. 239 [in Ukrainian].

(c) Riadinska Valeriia, Koller Yurii, Dikhtiarenko Kyrylo, 2019

DOI (Article): https://doi.org/10.36486/np.2019.2.09

Issue 2(44) 2019

http://naukaipravoohorona.com/ 
9. Pro Natsionalnyi bank Ukrainy. "About the National Bank of Ukraine": Law of Ukraine dated May 20, 1999 No. 679-XIV. Information from the Verkhovna Rada of Ukraine. 1999. № 29. Art. 238 [in Ukrainian].

10. Pro derzhavne rehuliuivannia vydobutku, vyrobnytstva i vykorystannia dorohotsinnyhk metaliv i kaminnia. "On state regulation of production and use of presious meyals and stounes, controlover their operations". low of Ukraine 18.11.1997 No.637/97-VR. 1998. Art.34[in Ukrainian].

11. Mytnyi kodeks Ukrainy. Vidomosti Verkhovnoyi Rady Ukrainy (VVR). "Customs Code of Ukraine”. Information from the Verkhovna Rada of Ukraine (VR). 2012. № 44-48. Art. 552 [in Ukrainian].

12. Pro zatverdzhennIa PolozhennIa pro zdiysnennIa operatsiy z bankivskymy metalamy ta vnesennIa zmin do deIakykh normatyvno-pravovykh aktiv Natsionalnoho banku Ukrainy. "On Approval of the Regulation on the Operations with Precious Metals and Amendment of Certain Legislative Acts of the National Bank of Ukraine": Resolution of the National Bank of Ukraine dated August 6, 2003 No. 325 [in Ukrainian].

13. Pro zatverdzhennIa Instruktsiyi z orhanizatsiyi perevezennIa valIutnykh tsinnostei ta inkasatsii koshtiv v ustanovakh bankiv. "On approval of the Instruction on the organization of the transportation of currency values and the collection of funds in the institutions of banks": NBU Decree No. 520 of 03.12.2003. URL: https://zakon.rada.gov.ua/laws/show/z0033-04/ed20070402/find? text $=\%$ C1\% E0\% ED\% EA\% B3\% E2\% F1\% FC\% EA\% B3 +\% EC\% E5\% F2\% E0\% EB\% E8 (date of application: 04.04.2019) [in Ukrainian].

14. Pro zatverdzhennia zmin do Instruktsii z orhanizatsii perevezennia valiutnykh tsinnostei ta inkasatsii koshtiv v ustanovakh bankiv. "On approval of amendments to the Instruction on the organization of transportation of currency values and collection of funds in institutions of banks": NBU Decree No. 644 of 15.12.2004. URL: https://zakon.rada.gov.ua/laws/show/z0033-05/ed20070402/ find? text $=\% \mathrm{C} 1 \% \mathrm{E} 0 \% \mathrm{ED} \% \mathrm{EA} \% \mathrm{~B} 3 \% \mathrm{E} 2 \% \mathrm{~F} 1 \% \mathrm{FC} \% \mathrm{EA} \% \mathrm{~B} 3+\% \mathrm{EC} \% \mathrm{E} 5 \% \mathrm{~F} 2 \% \mathrm{E} 0 \% \mathrm{~EB} \% \mathrm{E} 8$ (date of application: 04.04.2019) [in Ukrainian].

15. Pro zatverdzhennia Instruktsiyi z orhanizatsii inkasatsii koshtiv ta perevezennia valyutnykh tsinnostey u bankivskykh ustanovakh v Ukraini. "On approval of the Instruction on the organization of cash collection and transportation of currency values in banking institutions in Ukraine": NBU Decree No. 45 dated February 1, 2007. URL: https://zakon.rada.gov.ua/laws/show/z0181-07/ ed20130901 / find? text =\% C1\% E0\% ED\% EA\% B3\% E2\% F1\% FC\% EA\% B3 +\% EC\% E5\% F2\% E0\% EB\% E8 (date of application: 04.04.2019) [in Ukrainian].

16. Pro peremishchennia hotivky i bankivskykh metaliv cherez mytnyi kordon Ukrainy. "On the transfer of cash and bank metals through the customs border of Ukraine": NBU Decree dated May 27, 2008 No. 148. URL: https://zakon.rada.gov.ua/laws/show/z0520-08/ed20130607/ find?text $=\% \mathrm{C} 1 \% \mathrm{E} 0 \% \mathrm{ED} \% \mathrm{EA} \% \mathrm{~B} 3 \% \mathrm{E} 2 \% \mathrm{~F} 1 \% \mathrm{FC} \% \mathrm{EA} \% \mathrm{~B} 3+\% \mathrm{EC} \% \mathrm{E} 5 \% \mathrm{~F} 2 \% \mathrm{E} 0 \% \mathrm{~EB} \% \mathrm{E} 8$ (date of application: 04.04.2019) [in Ukrainian].

17. DSTU 28058. Zoloto u zlytkakh. Tekhnichni umovy. "DSTU 28058. Gold in ingots. Specifications. URL: http://docs.cntd.ru/document/gost-28058-89. (date of application: 04.04.2019) [in Ukrainian].

18. DSTU 28595. Sriblo u zlyvkakh. Tekhnichni umovy. "DSTU 28595. Silver in ingots. Specifications". URL: https://www.internet-law.ru/gosts/gost/4215/. (date of application: 04.04.2019) [in Ukrainian].

19. DSTU 12341-81 Platyna u zlyvkakh. Tekhnichni umovy. "DSTU 12341-81 Platinum in ingots. Specifications" [in Ukrainian].

20. DSTU 12340-81 Palladii u zlyvkakh. Tekhnichni umovy. "DSTU 12340-81 Palladium in ingots. Specifications". URL: http://gostexpert.ru/gost/gost-12340-81. (date of application: 04.04.2019) [in Ukrainian].

21. Dyba M.I., Vasylenko V.V. (2012) Klasyfikatsiia ta funktsii bankivskykh metaliv. "Classification and functions of banking metals": Sb. sciences works of the National un-state state Tax Service of Ukraine. No. 1. 101-110 pp. [in Ukrainian].

22. Istoricheskii slovar gallitsizmov russkogo yazyka. "Historical dictionary of gallicisms of the Russian language". M.: Dictionary publishing house ETS [in Russian].

23. Etymolohichnyi slovnyk ukrainskoi movy: u 7 t. / redkol. O.S. Melnychuk (hol. red.) ta in. "Etymological Dictionary of the Ukrainian Language": 7 t. / Redkol. O.S. Melnichuk (chief editor) and others. K.: Science. Thought, 1983. T. 5: P-T. Structure: R.V. Boldyrev and others. 2006. 704 p. [in Ukrainian].

24.Morfemno-orfograficheskii slovar. "Morpheme-spelling dictionary". M.: AST. Tikhonov A.N. 2002 [in Russian].

(c) Riadinska Valeriia, Koller Yurii, Dikhtiarenko Kyrylo, 2019

DOI (Article): https://doi.org/10.36486/np.2019.2.09 
25. Bolshaia sovetskaia entsiklopediia: v 30 t. gl. red. A.M. Prokhorov. 3-ie izd. "Great Soviet Encyclopedia”: 30 tons. Ch. ed. A.M. Prokhorov. 3rd ed. M.: Soviet Encyclopedia, 1969-1978 [in Russian].

26. Hehina M.A. (2009) Dragotsennyie metally i investitsionnyi spros. Dengi i kredit. "Precious metals and investment demand. Money and credit”. No 3. 214-221 pp. [in Russian].

27. Pro zatverdzhennia Polozhennia pro polityku upravlinnia mizhnarodnymy (zolotovaliutnymy) rezervamy Ukrainy. "On approval of the Regulation on the management of international (gold and currency) reserves of Ukraine": Regulation of the NBU dated April 26, 2018, No. 229-rsh. URL: https:// zakon.rada.gov.ua/laws/show/vr229500-18?lang=en (date of application: 04.04.2019) [in Ukrainian].

28. Starynskyi M.V. (2014) Pravovyi rezhym zolota yak obiekta valiutnykh pravovidnosyn. "Legal regime of gold as an object of currency legal relations". Scientific herald of Uzhgorod National University. 2014. The Pravo series. Whip 27. T. 2. 187-193 pp. [in Ukrainian].

29. Kucherov I.I. (2016) Monetarnyie metally i tezavratsiia. Dengi i kredit. "Monetary metals and hoarding”. Money and credit. No. 3. 212-221 pp. URL. http://www.old.fa.ru/dep/press/aboutus/Pages/Monetarnye-metally-i-tezavratsiya.aspx (date of application: 04.04.2019) [in Russian].

30. Gegina M. A. (2009) Dragotsennie metally i investitsionnyi spros. Dengi i kredit. "Precious metals and investment demand". Money and credit. No 3. 214-221 pp. [in Russian].

31. Zinkozsky M. A. (2012) Dragotsennyie metally kak obiekty bankovskikh sdelok. Yuridicheskaia rabota v kreditnoy organizatsii. "Precious metals as objects of banking transactions". Legal work in a credit institution. No 4. 87-98 pp. [in Russian].

32. Kucherov I.I. (2016) Monetarnyie metally i tezavratsiia. Dengi i kredit. "Monetary metals and thesaurus". Money and credit. No. 3. P. 212-221. URL: http://www.old.fa.ru/dep/press/aboutus/Pages/Monetarnye-metally-i-tezavratsiya.aspx (date of application: 04.04.2019) [in Russian].

33. Efremova K.V. (2009) Osoblyvosti pravovoho rehulyuvannia hospodarskoi diialnosti na rynku vyrobiv iz dorohotsinnykh metaliv i dorohotsinnoho kaminnia. "Features of legal regulation of economic activity in the market of articles of precious metals and precious stones": author's abstract. Dis. Ph. D. Kh. 20 p. [in Ukrainian].

34. Raizberg B.A. (2012) Sovremennyi sotsioekonomicheskiy slovar. "Modern socio-economic dictionary. M. 276 p. [in Russian].

UDC 336.742

Riadinska Valeria,

Doctor of Juridical Sciences, Full Professor, Chief of the Research Laboratory, State Research Institute MIA Ukraine, Kyiv, Ukraine, ORCID ID 0000-0002-2210-5933,

Koller Yurii, Candidate of Juridical Sciences, Senior Research Associate, Senior Researcher, State Research Institute MIA Ukraine, Kyiv, Ukraine, ORCID ID 0000-0002-9848-2348, Dikhtiarenko Kyrylo, Postgraduate, State Research Institute MIA Ukraine, Kyiv, Ukraine

\section{THE CONCEPT OF MONETARY METALS AND THEIR RATIO WITH THE CATEGORY OF "BANK METALS"}

The article deals with the issues of correlation between the concepts of "monetary metals" and "bank metals". Their definitions and use in the banking sphere, in the sphere of customs and currency regulation are investigated.

(c) Riadinska Valeriia, Koller Yurii, Dikhtiarenko Kyrylo, 2019

DOI (Article): https://doi.org/10.36486/np.2019.2.09 
The analysis of systematic changes in the legislation provided grounds for the conclusion that the term "monetary metals" was replaced by the term "bank metals", but the Law of Ukraine "On the National Bank of Ukraine" operates both with the term "bank metals" and the term "monetary metals".

Based on the analysis of legislation, the characteristics of monetary metals and bank metals were determined.

It is specified that bank metals represent precious metals in bullions and powders, brought (affined) to the highest standards in accordance with the world standards, which have a certificate of quality, and coins made of precious metals included in the currency values. On the basis of this, at the current stage only monetary gold can be classified as monetary metals.

It is substantiated that monetary gold and bank metals have different legal regimes, so monetary gold is not pertained to bank metals.

Considering the aforesaid, we ascertain that the monetary gold is gold affined to the highest standard in accordance with the world standard in bullions and coins, as well as gold placed on blocked accounts and non-locked gold accounts with nonresidents, providing the right to demand the delivery of gold.

Having a different legal regime with regard to monetary gold and bank metals, a different procedure of formation, storage and use is established, monetary gold is the exclusive property of the state, while bank metals may belong to banks, economic entities and individuals on the right of private ownership. The National Bank of Ukraine is the property manager of the monetary gold, but not its owner, while operations with bank metals can be carried out exclusively by its owners; monetary gold is an asset of the gold and foreign exchange reserve.

Keywords: monetary gold, bank metals, account blocking, gold and foreign exchange reserve, National Bank of Ukraine.

Отримано 05.06.2019 
Солдатенко Оксана Володимирівна,

доктор юридичних наук, професор, провідний науковий співробітник ДНДІ МВС України

ORCID ID 0000-0001-5633-2221

\section{ВІДНОВЛЕННЯ ДЕРЖАВНОГО СУВЕРЕНІТЕТУ В ОКРЕМИХ РАЙОНАХ УКРАЇНИ: ПОЛІТИЧНІ ПІДХОДИ ТА НАУКОВЕ ОБГРУНТУВАННЯ}

У пропонованій статті розглядаються погляди сучасних украӥнських політиків (А. Авакова, А. Гриценка, В. Зеленського, П. Порошенка, Ю. Тимошенко) на проблему відновлення державного суверенітету на територіях окремих районів Донецької та Луганської областей. Застосування контекстного, юридичного, порівняльного, логіко-системного, системно-структурного методів аналізу дозволили визначити рівень наукової обгрунтованості та можливостей практичної реалізації кожного із таких підходів. У статті доведено, що державний суверенітет на території окремих районів Донецької та Луганської областей вважатиметься відновленим за умови верховенства украӥнської влади, безумовного дотримання норм начіонального і міжнародного права та неможливості довільного відчуження легітимної влади при одночасній можливості делегування прав органам місцевого самоврядування відповідних районів.

Ключові слова: окремі райони Донецької та Луганської областей; відновлення державного суверенітету, миротворча операчія ООН, переговори, договірна реінтеграчія, референдум.

Упродовж п'яти останніх років актуальною для України залишається проблема відновлення державного суверенітету на території окремих районів Донецької та Луганської областей. Відповідні території визначено Указом Президента України від 7 лютого 2019 року № 32/2019, до яких віднесено: у Донецькій області - Донецьк, Горлівку, Дебальцеве, Докучаєвськ, Снакієве, Макіївку, Сніжне, Харцизьк, Шахтарськ та інші; у Луганській - Луганськ, Алчевськ, Антрацит, Брянку, Должанський, Первомайськ, Ровеньки, Сорокино, Кришталевий та інші. В Указі також наведено перелік повністю або частково захоплених районів Донецької та Луганської областей [1].

Мета цього дослідження полягає в аналізі запропонованих окремими політиками України підходів до відновлення державного суверенітету на території окремих районів Донецької та Луганської областей (що передбачає варіанти вирішення збройного конфлікту на Донбасі) на предмет їх наукової обгрунтованості та вибір найбільш імовірного й ефективного із таких підходів (варіантів, сценаріїв).

Перший підхід, який пропонується розглянути, ініційовано п'ятим Президентом України П. Порошенком. На його думку, найоптимальнішим сценарієм відновлення державного суверенітету на територіях окремих районів Донецької

DOI (Article): https://doi.org/10.36486/np.2019.2.10

(c) Soldatenko Oksana, 2019 
і Луганської областей є розміщення миротворчої місії ООН на всій окупованій території, у результаті чого миротворці сприятимуть роззброєнню незаконних збройних формувань та візьмуть під контроль неконтрольовану ділянку кордону, що дозволить не допустити російські війська на окуповану територію. Необхідними ресурсами для реалізації такого плану є контингент військовослужбовців у кількості 20 тис. осіб та 4 тис. поліцейських [2].

У контексті такого бачення вирішення конфлікту на Донбасі П. Порошенком та з огляду на позицію Міністра МВС України А. Авакова щодо реалізації “механізму малих кроків” - введення миротворців поступово в кожний окремий район, що, з часом, дозволить контролювати кордон з окупованою територією “блакитними касками” спільно з українськими прикордонниками, актуальною є Наукова записка, підготовлена науковцями Інституту держави і права ім. В.М. Корецього [3]. У ній представлено аналіз досвіду здійснення основних видів сучасних миротворчих операцій та визначено основні чинники успішності таких операцій. Зважаючи, що в законодавстві України не враховано специфіку міжнародної миротворчої операції, у записці обгрунтовані пропозиції щодо внесення змін і доповнень до законодавства України (у разі здійснення на території України міжнародної операції з підтримання миру і безпеки): проект Закону України “Про внесення змін і доповнень до Закону України “Про порядок допуску та умови перебування підрозділів збройних сил інших держав на території України””, проекти Законів України “Про внесення змін і доповнень до Митного кодексу України”, “Про внесення змін і доповнень до Податкового кодексу України".

У четвертому розділі Наукової записки детально розкрито порядок в’їзду на територію України членів Місії: в’їзні документи, прикордонний контроль, митний огляд, свобода пересування, особливості реалізації членами Місії права на охорону здоров’я в Україні, привілеї та імунітети Місії та її членів [3, с. 148-191].

Водночас нагадаємо, що у ст. 33 розділу VI Статуту ООН однією з форм миротворчої діяльності є ухвалення Радою Безпеки (далі - РБ) ООН вимоги до сторін міжнародного конфлікту вирішити спір шляхом: переговорів; обстеження; посередництва; примирення; арбітражу; судового розгляду; звернення до регіональних органів чи угод, чи за допомогою інших мирних засобів за їх вибором. Крім того, РБ має бути проведено розслідування спору з метою визначення, чи загрожує він міжнародному миру та безпеці (ст. 34).

Відповідно до сформульованих у заяві Голови РБ від імені РБ S/PRST/ 1994/22 від 3 травня 1994 р., критеріями, які мають враховуватися при ухваленні рішення щодо проведення нової миротворчої операції ООН, є такі:

1) чи існує ситуація, продовження якої може поставити під загрозу або вже становить загрозу міжнародному миру та безпеці;

2) чи існують регіональні чи субрегіональні організації та органи і чи готові та спроможні вони допомогти у вирішенні ситуації;

3) чи припинено вогонь і чи сторони віддані мирному процесу, спрямованому на досягнення політичного врегулювання;

4) чи існує чітка політична мета і чи їі можна відобразити в мандаті;

5) чи можна сформулювати чіткий мандат для операції ООН;

DOI (Article): https://doi.org/10.36486/np.2019.2.10

(c) Soldatenko Oksana, 2019 
6) чи можна забезпечити безпеку персоналу ООН, зокрема чи можна отримати розумні гарантії від основних сторін щодо безпеки персоналу ООН [3, с. 33].

Крім того, як зазначають автори Наукової записки, у виступі Генерального секретаря на засіданні РБ з ініціативою “Акція для підтримання миру” від 28 березня 2018 р. названі умови миротворчої операції:

1) наявність передумов для операції у країні;

2) наявність фінансування;

3) неможливість суто політичного вирішення конфлікту;

4) можливість формулювання чіткого і вузького за своїми завданнями мандату РБ [3, с. 34].

Все наведене вище викликає сумнів щодо можливості введення на територію окремих районів Донецької та Луганської областей миротворців ООН, оскільки ситуація в Україні не відповідає усім необхідним ні критеріям, ні умовам такої миротворчої операції.

За іншим сценарієм, запропонованим новообраним Президентом України В. Зеленським, одним із шляхів урегулювання конфлікту є мирні переговори 3 російськими представниками, в центрі яких - збереження життя людей, та винесення на референдум чи онлайн-голосування списку домовленостей, досягнутих у результаті переговорного процесу [4]. Наукове обгрунтування такого підходу можна знайти у монографії, виданій Національним інститутом стратегічних досліджень у 2015 році [5].

У ній зазначено, що проект договірної реінтеграції передбачає наявність спільних економічних інтересів Києва і Донецька та гарантій, наданих місцевим елітам щодо збереження активів і преференцій. Як вважають автори цієї монографії, важливо оцінити ймовірність реалізації договірного сценарію реінтеграції Донбасу, що може здійснюватися у спосіб компромісу з наявною переговорною стороною (ДНР/ЛНР) або у спосіб її заміни на більш лояльне до України представництво окупованих територій. У цьому контексті авторами монографії пропонується розглянути варіант компромісу з представниками ДНР/ЛНР на основі Мінських домовленостей (молдавський варіант) і окреслено позитивні аспекти такого сценарію: імовірність остаточного припинення збройного конфлікту на Донбасі; імовірність підтримання рішення з боку Заходу і Росії та вірогідність укладення нового варіанту Будапештського меморандуму (щодо гарантій безпеки); імовірність отримання фінансової допомоги для відновлення Донбасу [5, с. 254].

Водночас до негативних аспектів реалізації такого сценарію віднесено фактичне визнання конфлікту (і причин його виникнення) внутрішньою українською проблемою; визнання успіху ДНР/ЛНР у війні “за незалежність”; створення прецеденту автономізації через заколот для інших регіональних еліт; фактичне усунення питання Криму з порядку денного світової політики.

На думку авторів монографії [5], сприятливий прогноз такого варіанта пов'язаний тільки з гарантіями збереження (і зростання) підтримки України з боку Заходу, а також - з повною відмовою Росії від подальшого тиску на Україну та підриву іiї державності. Як зазначено у монографії, оскільки таких гарантій не існує, цей варіант слід розглядати як однозначно програшний. Проте, на нашу думку, його не варто категорично відкидати, оскільки зміна політичної ситуації

DOI (Article): https://doi.org/10.36486/np.2019.2.10

(c) Soldatenko Oksana, 2019 
в Україні на сьогодні та риторика американських і російських високопосадовців $[6,7]$ повністю сприяють його реалізації. Зацікавлені в такому варіанті як Російська Федерація, так і представники Заходу, які хочуть припинити тиск на Росію і зменшити витрати на підтримку України [5, с. 255].

У монографії [5] також розглянуто сценарій добровільної реінтеграції окупованих територій на основі волевиявлення їх мешканців та організованого для цього спеціального переговорного процесу з політичними представниками регіону (за прикладом німецького варіанта). Реалізація на практиці такого сценарію вбачається малоймовірною, проте автори згаданої монографії переконливо наводять його позитивні аспекти: отримання Україною повної моральної сатисфакції в конфлікті та спростування російської позиції про причини конфлікту; створення виняткового позитивного резонансу для відносин України з СС, країнами пострадянського простору, можливості перегорнути сторінку у відносинах з РФ (на позитивній для України основі); створення передумов обстоювання Україною ії̈ економічних та політичних умов реінтеграції, оскільки вона посідатиме вигідну переговорну позицію; створення умов для порушення питання про повернення Криму до складу України як логічного продовження процесу.

Серед негативних наслідків реалізації такого сценарію названо часткове прийняття вимог автономності окремих територій; надання гарантії місцевим елітам щодо збереження їх контролю над економічними і політичними процесами; можливість настання соціально-економічних складнощів як наслідку реінтегрування, що призведе до чергової внутрішньополітичної кризи та загальмує процес реформ і модернізації [5, с. 256].

Щодо ініціативи Президента України В. Зеленського провести референдум 3 питання переговорного процесу між Україною і Росією, то у науковій літературі також розглядався й викладений на належному науково-теоретичному рівні такий сценарій розвитку подій. Зокрема, Т. Острицьким пропонувалося спочатку провести референдум на території Донецької і Луганської областей з питанням про те, хоче чи не хоче населення регіону залишатися в складі України. Після цього референдуму пропонувалося винести відповідне питання на всеукраїнський референдум, чим остаточно його вирішити [8]. За оцінкою М. Погребінського, це єдиний доцільний варіант завершення конфлікту. Якщо більшість населення Донбасу не захоче знаходитися в складі України, то в під час всеукраїнського референдуму буде з'ясовано думку громадян України: дати Донбасу вийти 3 України чи навпаки - утримувати його. Політолог вважає, що більшість населення Донбасу проголосує за те, щоб залишитися у складі України з певними повноваженнями (надання автономії тощо) [9], що вимагатиме проведення в таких районах місцевих виборів за українським законодавством. Однак відсутність в Україні Закону “Про всеукраїнський та місцеві референдуми” як способу вирішення актуальних питань державного і місцевого значення не дозволяє у нинішніх умовах реалізувати саме такий сценарій.

Крім того, окремими політиками пропонувалися й інші підходи щодо відновлення державного суверенітету на території окремих областей Донецької та Луганської областей. Зокрема, Ю. Тимошенко вбачала необхідність у зміні Мінського формату на Будапешт+ через проведення міжнародного саміту і переговорів

DOI (Article): https://doi.org/10.36486/np.2019.2.10

(C) Soldatenko Oksana, 2019 
з представниками США і СС; посиленні української армії; негайному вступі України до НАТО; посиленні санкцій проти Росії; створенні міжнародного фонду відновлення і розвитку Донбасу та фонду виплат матеріальної компенсації [10]. Наукового обгрунтування таким підходам у дослідженій літературі не знайдено.

А. Гриценком пропонувалося повернення окупованих територій без “особливих статусів” дипломатичними, військовими, економічними, санкційними засобами спільно із зарубіжними партнерами, але без вирішення у двосторонньому форматі Україна”Росія, а тільки в чотиристоронньому - Україна”Росія"Свропа"США та через введення міжнародної миротворчої місії (як з військовим компонентом, так і з поліцейсько-цивільним) [11]. Такий підхід не знайшов свого обгрунтування у наукових джерелах, крім того, він містить ризик задоволення інтересів СС і США, які не завжди збігаються як з політичними, так і з економічними інтересами України, що і зумовлює недоцільність його реалізації.

Як видно із наведених підходів, усі вони передбачають мирний варіант вирішення ситуації на Донбасі, але водночас не містять єдиного рішення проблеми урегулювання конфлікту, а кардинально відрізняються один від одного: пропонується досягнення відповідних домовленостей у результаті переговорного процесу як із жителями окупованих територій, так і з російськими представниками (В. Зеленський) або категорично заперечують переговори у двосторонньому форматі, а передбачають участь у них СС та США (Ю. Тимошенко, А. Гриценко), або передбачають розміщення миротворчої місії ООН (П. Порошенко, А. Аваков, А. Гриценко).

У проаналізованих політичних підходах не зустрічається сценарій заморожування конфлікту, однак, за результатами дослідження, викладеними у монографії [12], презентуються результати міжнародного експертного дослідження щодо напрямів вирішення військового конфлікту на Сході України. У ньому з'ясовано, що найбільшу імовірність здійснення має сценарій “В Україні буде заморожений конфлікт” (№ 10) та “Україна поверне собі території ДНР та ЛНР (без Криму) в умовах федералізації або спеціального статусу)” (№ 9). Найменш імовірними є сценарії № 1 “Україна здійснить власний стрибок у розвитку", № 4 "Україна увійде в НАТО”, № 6 "В Україні і на окупованих територіях ООН проведе миротворчу операцію”, № 7 ”Україна поверне собі Крим, ДНР та ЛНР”, № 8 “Україна поверне собі території ДНР та ЛНР (без Криму) в умовах унітарної держави”, № 12 ”Відбудеться воєнна агресія Росії, ДНР та ЛНР”. Найнижчу ймовірність здійснення мають сценарії № 5 "Україна увійде в СС”, № 11 "В Україні буде громадянська війна”, № 13 “Україна розколеться на квазідержави”, № 14 “ДНР та ЛНР увійдуть до Російської Федерації”, № 15 “Україна увійде в Свразійський простір” [12, с. 51].

Зважаючи на імовірність реалізації сценарію "Україна поверне собі території ДНР та ЛНР (без Криму) в умовах федерації або спеціального статусу”, доцільно погодитися з думкою Р. Додонова про те, що “необхідно думати, як змінити менталітет населення Л/ДНР у разі повернення цих територій в український політичний простір, адже без цього Донбас буде періодично відтворювати конфліктні ситуації, погрожуючи цілісності країни” [13, с. 158].

DOI (Article): https://doi.org/10.36486/np.2019.2.10

(C) Soldatenko Oksana, 2019 
Отже, проаналізувавши підходи окремих політиків до вирішення проблеми відновлення державного суверенітету на території окремих районів Донецької та Луганської областей та результати опублікованих наукових досліджень, що обгрунтовують такі підходи, можна дійти висновку, що не існує єдиної думки $з$ приводу того, які сценарії мають більшу імовірність розвитку, а які - найменшу. Водночас в Україні є необхідність обрання сценарію (варіанта, підходу), за якого б відбулося реальне відновлення державного суверенітету, що передбачає досягнення таких ознак суверенітету: верховенство української влади, тобто відсутність будь-якої іншої публічної влади на цій території; самостійність, що передбачає безумовне дотримання норм як національного, так і міжнародного права; повнота - поширення впливу української влади на всі сфери життя та на все населення; невідчужуваність - неможливість довільного відчуження легітимної та легальної влади, за одночасної можливості делегування суверенних прав держави Україна органам місцевого самоврядування відповідних районів.

Для забезпечення повноцінного процесу відновлення державного суверенітету на території окремих районів Донецької та Луганської областей важливо вирішити завдання, передбачені ст. 4 Закону України від 18 січня 2018 року № 2268-VIII "Про особливості державної політики із забезпечення державного суверенітету України на тимчасово окупованих територіях у Донецькій та Луганській областях” [14]:

1) звільнення тимчасово окупованих територій у Донецькій та Луганській областях та відновлення на цих територіях конституційного ладу;

2) захист прав, свобод і законних інтересів фізичних та юридичних осіб (захист основоположних політичних і громадянських прав і свобод людини; вжиття заходів для звільнення Російською Федерацією, окупаційною адміністрацією Російської Федерації всіх незаконно затриманих, утримуваних громадян України; сприяння забезпеченню відновлення порушених матеріальних прав; сприяння забезпеченню соціально-економічних, екологічних та культурних потреб);

3) забезпечення незалежності, єдності та територіальної цілісності України.

Вирішення цих завдань потребує суттєвих, передусім, економічних затрат, які на сьогодні в Україні відсутні, що вимагає залучення їх із зовнішніх джерел та забезпечення економічного зростання через нарощування обсягів вітчизняного виробництва, що в умовах сьогодення є вкрай складним і майже невирішуваним.

\section{СПИСОК ВИКОРИСТАНИХ ДЖЕРЕЛ}

1. Про межі та перелік районів, міст, селищ і сіл, частин їх територій, тимчасово окупованих у Донецькій та Луганській областях: Указ Президента України від 7 лютого 2019 року № $32 /$ 2019. URL: https://www.president.gov.ua/documents/322019-26050 (дата звернення: 06.05.2019).

2. Баланчук I. Порошенко: Миротворці - єдиний варіант миру на Донбасi. URL: https:// www.pravda.com.ua/rus/news/2018/02/28/7173148/ (дата звернення: 06.05.2019).

3. Проценко I.M., Савчук К.О., Стойко О.М. Політико-правові засади миротворчої операції на Донбасі: світовий досвід для України: наукова записка / Кресін О.В. (кер. авт. кол., наук. ред.), Київ: Інститут держави і права ім. В.М. Корецького НАН України, 2018. 243 с.

4. Булатчик B. Выборы президента: Владимир Зеленский о войне и мире. URL: https:// www.ostro.org/general/politics/articles/561769/ (дата звернення: 06.04.2019).

5. Донбас і Крим: ціна повернення / за заг. ред. В.П. Горбуліна, О.С. Власюка, Е.М. Лібанової, О.М. Ляшенко. К.: НІСД, 2015. 474 с.

DOI (Article): https://doi.org/10.36486/np.2019.2.10

(C) Soldatenko Oksana, 2019

Issue 2(4.4) 2019

http://naukaipravoohorona.com/ 
6. Волкер поддержал прямые переговоры Зеленского и Путина. URL: https:// www.pravda.com.ua/rus/news/2019/04/23/7213303/ (дата звернення: 06.04.2019).

7. "C чистого листа": в России предложили Украине начать отношения сначала. URL: https://antikor.com.ua/articles/306524-s_chistogo_lista_v_rossii_predlohili_ukraine_nachatj_ otnoshenija_snachala (дата звернення: 06.05.2019).

8. Східноукраїнський конфлікт в контексті глобальних трансформацій: зб. статей. Київ: Український інститут стратегій глобального розвитку і адаптації, 2016. Вип. 2. 270 с.

9. Скворещь B.O. Моделі мирного врегулювання східноукраїнського конфлікту. URL: https:/ /uisgda.com/ua/model_mirnogo_vregulyuvannya_shdnoukranskogo_konflktu.html (дата звернення: 06.05.2019).

10. Булатчик В. Выборы президента: как Юлия Тимошенко хочет возвращать Донбасс и Крым. URL: https://www.ostro.org/general/politics/articles/562324/ (дата звернення: 06.05.2019).

11. Булатчик B. Выборы президента: Анатолий Гриценко и его мирный план. URL: https:/ /www.ostro.org/general/politics/articles/562083/ (дата звернення: 06.05.2019).

12. Миротворення в умовах гібридної війни в Україні / за заг. ред. М.А. Лепського. Запоріжжя: КСК-Альянс, 2017. 172 с.

13. Додонов Р.О. Конфлікт на Сході України у дзеркалі соціально-філософської рефлексії: монографія. Український інститут стратегій глобального розвитку та адаптації. Вінниця: ГЛОБУС ПРЕСС, 2016. 200 c.

14. Про особливості державної політики із забезпечення державного суверенітету України на тимчасово окупованих територіях у Донецькій та Луганській областях: Закон України від 18 січня 2018 року № 2268-VIII. URL: https://zakon.rada.gov.ua/laws/show/2268-19 (дата звернення: 06.05.2019).

\section{REFERENCES}

1. Pro mezhi ta perelik raioniv, mist, selyshch i sil, chastyn yikh terytorii, tymchasovo okupovanykh u Donetskii ta Luhansikii oblastiakh. "On the boundaries and list of districts, cities, villages and villages, parts of their territories temporarily occupied in Donetsk and Luhansk oblasts": Decree of the President of Ukraine dated February 7, 2019, No. 32/2019. URL: https://www.president.gov.ua/ documents/322019-26050 (date of application: 06.05.2019) [in Ukrainian].

2. Balanchuk I. Poroshenko: Myrotvortsi - yedynyi variant myru na Donbasi. "Balanchuk I. Poroshenko: Peacekeepers - the only option for peace in the Donbass". URL: https://www. pravda.com.ua/eng/news/2018/02/28/7173148/ (date of application: 06.05.2019) [in Ukrainian].

3. Polityko-pravovi zasady myrotvorchoi operatsii na Donbasi: svitovyi dosvid dlia Ukrainy. "Political and legal principles of a peacekeeping operation in the Donbass: world experience for Ukraine": scientific note / O. Kresin (Head of the college, ed.), Protsenko I.M., Savchuk K.O., Stoyko O.M. Kyiv: V. Koretsky Institute of State and Law of the National Academy of Sciences of Ukraine, 2018. 243 p. [in Ukrainian].

4. Bulatchik V. Vybory prezidenta: Vladimir Zelenskii o voyne i mire. "Election of the President: Vladimir Zelensky about War and Peace". URL: https://www.ostro.org/general/politics/articles/ 561769/ (date of application: 06.04.2019) [in Russian].

5. Donbas i Krym: tsina povernennia. "Donbass and Crimea: the price of return" / per community edit V.P. Gorbulina, A.S. Vlasiuk, E.M. Libanova, A.M. Liashenko. K.: NISS, 2015. 474 p. [in Ukrainian].

6. Volker podderzhal pryamyie peregovory Zelenskogo i Putina. "Volker supported direct negotiations between Zelensky and Putin”. URL: https://www.pravda.com.ua/rus/news/2019/04/ 23/7213303/ [in Russian].

7. "S chistogo lista": v Rossii predlozhili Ukraine nachat otnosheniia snachala. "From scratch": in Russia, Ukraine was offered to start a relationship over again. URL: https://antikor.com.ua/articles/306524-s_chistogo_lista_v_rossii_predlohili_ukraine_nachatj_otnoshenija_snachala (date of application: 06.05.2019) [in Russian].

8. Skhidnoukrainsikyi konflikt v konteksti hlobalnykh transformatsii. "East-Ukrainian conflict in the context of global transformations": Sb. articles. Kyiv: Ukrainian Institute for Strategies for Global Development and Adaptation, 2016. Iss. 2. 270 p. [in Ukrainian].

9. Skvorets V.O. Modeli myrnoho vrehuliuvannia skhidnoukrainskoho konfliktu. "Models of Peaceful Settlement of East-Ukrainian Conflict". URL: https://uisgda.com/en/

DOI (Article): https://doi.org/10.36486/np.2019.2.10

(C) Soldatenko Oksana, 2019 
model_mirnogo_vregulyuvannya_shdnoukranskogo_konflktu.html. (date of application: 06.05.2019) [in Ukrainian].

10. Bulatchik $V$. Vybory prezidenta: kak Yuliia Timoshenko khochet vozvrashchat Donbass i Krym. "Presidential elections: how Yulia Tymoshenko wants to return the Donbass and the Crimea". URL: https://www.ostro.org/general/politics/articles/562324/ (date of application: 06.05.2019) [in Russian].

11. Bulatchik V. Vybory prezidenta: Anatolii Gritsenko i yego mirnyi plan. "Presidential Elections: Anatoly Gritsenko and his peace plan". URL: https://www.ostro.org/general/politics/ articles/562083/ (date of application: 06.05.2019) [in Russian].

12. Myrotvorennia v umovakh hibrydnoi viiny v Ukraini / za zah. red. M. A. Lepskoho. "Peacemaking in a hybrid war in Ukraine" / per coalition. edit M. A. Lepski Zaporizhzhia: KSK-Allianc, 2017. 172 p. [in Ukrainian].

13. Dodonov R.O. (2016) Konflikt na Skhodi Ukrainy u dzerkali sotsialno-filosofskoi refleksii : monohrafiia. "Conflict in the East of Ukraine in the mirror of socio-philosophical reflection": monograph. Ukrainian Institute of Strategies for Global Development and Adaptation. Vinnitsa: GLOBUS PRESS. 200 p. [in Ukrainian].

14. Pro osoblyvosti derzhavnoi polityky iz zabezpechenna derzhavnoho suverenitetu Ukrainy na tymchasovo okupovanykh terytoriiakh u Donetskii ta Luhanskii oblastyakh. "On the peculiarities of the state policy of ensuring the state sovereignty of Ukraine in temporarily occupied territories in the Donetsk and Luhansk oblasts": Law of Ukraine dated January 18, 2018, No. 2268-VIII. URL: https://zakon.rada.gov.ua/laws/show/2268-19 (date of application: 06.05.2019) [in Ukrainian].

UDC 321.011(477.61+477.62)

Soldatenko Oksana, Doctor of Juridical Sciences, Professor, Leading Researcher, State Research Institute MIA Ukraine, Kyiv, Ukraine, ORCID ID 0000-0001-5633-2221

\section{RESTORATION OF STATE SOVEREIGNTY IN SELECTED AREAS OF UKRAINE: POLICY APPROACHES AND SCIENTIFIC RATIONALE}

The article deals with the views of contemporary Ukrainian politicians on the problem of restoration of state sovereignty in the territories of certain districts of Donetsk and Luhansk oblasts. The application of context, legal, comparative, logicalsystem, system-structural methods of analysis allowed to determine the level of scientific feasibility and opportunities for practical implementation of each of the proposed approaches. In particular, it is noted that due to the incompatibility of the domestic situation with all the necessary criteria and conditions of the UN peacekeeping operation, the implementation of the proposals of the fifth President of Ukraine P. Poroshenko (similar approaches were also expressed by A. Avakov and A. Gritsenko) is unlikely, as well as approaches, proposed by Y. Tymoshenko (regarding the change of the Minsk format on Budapest + through holding an international summit and negotiations with representatives of the USA and the EU). More probable and wellfounded scholars (in the research results published during 2015-2019) have scenarios related to the freezing of the conflict, as well as with the contractual reintegration on the basis of negotiations and the possible holding of a referendum (V. Zelensky).

DOI (Article): https://doi.org/10.36486/np.2019.2.10

(c) Soldatenko Oksana, 2019 
DOI (Issue): https://doi.org/10.36486/np.2019.2

At the same time, the implementation of all proposed options for the restoration of state sovereignty in the Donbass requires significant economic costs, which can not be achieved without providing economic growth and restoring common economic interests of Kyiv and Donetsk in Ukraine.

State sovereignty on the territory of certain districts of Donetsk and Luhansk oblasts will be considered restored under the condition of the supremacy of the Ukrainian authorities, unconditional compliance with the norms of national and international law, and the impossibility of arbitrary alienation of legitimate power, while the possibility of delegating rights to local self-government bodies of the respective districts.

Keywords: separate districts of Donetsk and Luhansk, restoration of state sovereignty, UN peacekeeping operations, negotiations, contractual reintegration, referendum.

Отримано 05.06.2019 


\section{Циганов Олег Григорович,} доктор юридичних наук, доцент, головний науковий співробітник ДНДІ МВС України, м. Київ, Україна

ORCID ID 0000-0002-8924-1139

\section{ВИДИ ПОЛІЦЕЙСЬКИХ ПОСЛУГ В УКРАЇНІ ТА ОРГАНІЗАЦІЙНО-ПРАВОВЕ ЗАБЕЗПЕЧЕННЯ ÏХ НАДАННЯ}

Статтю присвячено дослідженню основних видів полічейсъких послуг в Україні та організащійно-правового забезпечення їх надання. Наголошується, що на сьогодні ні в наукових колах, ні в колах практичних прачівників не сформовано єдиного підходу до розуміння феномену поліщейських послуг як однієї з основних форм полічейської діяльності. Наведено авторську дефініцію поняття "поліщейська послуга”, визначено основні види поліщейських послуг залежно від змісту поліщейської діяльності в Украӥні та охарактеризовано їх організачійно-правове забезпечення.

Ключові слова: публічно-сервісна діяльність, полічейська діяльність, поліцейська послуга.

На сьогодні в Україні сервісний фактор стає визначальним символом органів публічної влади, в тому числі створеного на підгрунті ліквідованої міліції нового правоохоронного органу - Національної поліції України. Зазначене однозначно слід тлумачити як позитивний крок у розвитку вітчизняної правоохоронної системи демократичного суспільства. Водночас, незважаючи на тривалі дискусії щодо змістовного тлумачення такого виду публічних послуг, як поліцейська послуга, ні в наукових колах, ні в колах практичних працівників досі не сформовано єдиного підходу до розуміння сутності цього феномену. Більше того, зі змісту Закону України “Про Національну поліцію” неможливо встановити, чи така послуга є процесом, чи результатом реалізації владних повноважень. За відсутності індивідуальних ознак поняття “поліцейська послуга” набуває важливого значення, оскільки визначення цієї інформації дозволило б точно класифікувати, до якого виду зазначених послуг відносити відповідну послугу і нормами якої правової галузі забезпечити іï правову реалізацію.

Науковій розробці проблем поліцейської діяльності присвятили свої праці такі вчені-адміністративісти, як М.І. Ануфрієв, О.М. Бандурка, Ю.П. Битяк, В.М. Білик, І.П. Голосніченко, І.В. Зозуля, Ю.І. Римаренко, Д.П. Калаянов, А.Т. Комзюк, І.В. Кріцак, М.В. Лошицький, О.С. Проневич, О.П. Угровецький, М.Ю. Фролов, О.С. Юнін та багато інших. Їхні праці мають важливе наукове та практичне значення. Проте у дослідженнях зазначених науковців питанням визначення сутності й змісту поліцейських послуг, їх класифікації та нормативноправового забезпечення належної уваги не приділялося.

DOI (Article): https://doi.org/10.36486/np.2019.2.11

(C) Tsyhanov Oleh, 2019 
Мета статті полягає у визначені сутності поліцейських послуг, їх класифікації за видами поліцейської діяльності та характеристиці організаційно-правового забезпечення надання.

Метою поліцейської діяльності є реалізація поліцейської функції щодо встановлення та забезпечення внутрішньої безпеки та правопорядку в державі спеціально уповноваженими державними органами - органами поліції. На сьогодні важливим є питання про те, на що або на кого спрямована зазначена діяльність для реалізації встановленої перед органами поліції мети, або, іншими словами, що виступає об’єктом поліцейської діяльності. Вважаємо, що залежно від конкретного виду поліцейської діяльності її об'єктом виступає захист і охорона суспільних відносин органами поліції, наділених владними повноваженнями 3 відповідною функціональною спеціалізацією.

За результатами аналізу чинних нормативно-правових актів та практики реалізації правоохоронної функції органами та підрозділами Національної поліції України до основних видів поліщейської діяльності в Україні слід віднести: 1) адміністративну поліцейську діяльність; 2) кримінально-процесуальну поліцейську діяльність; 3) поліцейську діяльність оперативно-розшукових підрозділів; 4) інформаційно-аналітичну поліцейську діяльність; 5) охоронну поліцейську діяльність.

Разом із поліцейськими заходами однією 3 основних форм поліцейської діяльності є поліцейські послуги. При цьому, з розвитком і втіленням у діяльність державних органів принципу верховенства права та непорушності основоположних прав і свобод людини, пріоритетним завданням поліції здебілышого стає виконання сервісних правоохоронних функцій, а не тільки здійснення превентивних, репресивних та каральних заходів.

Під поліщейською послугою нами розуміється передбачена законом публічновладна діяльність органу або підрозділу поліції, що грунтується й випливає 3 виконуваних цим органом (підрозділом) поліцейських функцій, безпосередньо пов’язаних із забезпеченням прав і свобод людини, інтересів суспільства і держави, протидією злочинності, підтриманням публічної безпеки і порядку, та виражається у здійсненні дій чи прийнятті рішень, котрі відбуваються в контакті з конкретною фізичною чи юридичною особою, яка звертається до відповідного органу (підрозділу) поліції, його посадової особи з метою реалізації своїх суб'єктивних прав, свобод та законних інтересів та/або виконання покладених на цю особу нормативними правовими актами обов’язків у сфері компетенції поліції.

Отже, однією 3 найбільш характерних ознак поліцейської послуги, як і будь-якої іншої послуги, є первинність потреб замовника цієї послуги у діях її надавача, а також індивідуальний характер надання такої послуги фізичній чи юридичній особі, яка має на це право.

Послуги, що надаються органами та підрозділами поліції, залежно від змісту поліцейської діяльності в Україні можна розподілити на такі чотири групи: 1) адміністративні поліцейські послуги; 2) інформаційні поліцейські послуги; 3) охоронні поліцейські послуги; 4) інші поліцейські послуги.

Виконання значної частини обов’язків органами поліції перед приватними особами пов'язано з таким важливим напрямом їх діяльності, як надання адміністративних послуг. Під адміністративною поліщейською послугою слід розуміти

DOI (Article): https://doi.org/10.36486/np.2019.2.11

(C) Tsyhanov Oleh, 2019 Issue 2(44) 2019 http://naukaipravoohorona.com/ 
передбачену законом публічно-владну діяльність органу (підрозділу) поліції, здійснювану за заявою фізичної або юридичної особи щодо створення організаційних умов для реалізації її прав, свобод і законних інтересів та/або виконання покладених на неї законом обов'язків у сфері діяльності Національної поліції України шляхом прийняття та документального оформлення відповідного адміністративного акта, який має індивідуальне призначення та зовнішню сферу застосування.

Правовий статус органів Національної поліції України як суб’єктів правовідносин щодо надання адміністративних послуг визначається в основному Законом України “Про адміністративні послуги” від 6 вересня 2012 р. № 5203-VI як загальним законодавчим актом, що встановлює правові засади реалізації прав, свобод і законних інтересів фізичних та юридичних осіб у сфері надання адміністративних послуг, а також іншими нормативно-правовими актами України. При цьому на відносини щодо об'єктів, обмежених у цивільному обігу, зокрема зброї, Закон України “Про адміністративні послуги” не поширюється [1, п. 13 ч. 2 ст. 2]. Відносини щодо обігу таких об'єктів і предметів регулюються іншими законодавчими та підзаконними нормативними актами України.

Також до нормативно-правових актів, що регламентують діяльність органів поліції щодо надання адміністративних послуг, слід віднести: Закон України “Про дозвільну систему у сфері господарської діяльності" від 6 вересня 2005 р. № 2806-IV, який визначає правові та організаційні засади функціонування дозвільної системи у сфері господарської діяльності і встановлює порядок діяльності дозвільних органів (зокрема, відповідних підрозділів Національної поліції України), уповноважених видавати документи дозвільного характеру, та адміністраторів; Закон України “Про Національну поліцію” від 2 липня 2015 р. № 580-VIII, ст. 23 якого встановлює основні повноваження поліції, в тому числі щодо надання окремих адміністративних послуг (зокрема, п.п. 5, 12-16 цієї статті Закону); постанова Верховної Ради України “Про право власності на окремі види майна” від 17 червня 1992 р. № 2471-ХІІ, якою затверджено перелік видів майна, що не може перебувати у власності громадян, громадських об'єднань, міжнародних організацій та юридичних осіб інших держав на території України та встановлено спеціальний порядок набуття права власності громадянами на окремі види майна; постанова Кабінету Міністрів України “Про затвердження Положення про дозвільну систему” від 12 жовтня 1992 р. № 576, якою затверджено Положення, котре визначає предмети, матеріали і речовини, підприємства, майстерні й лабораторії, на які поширюється дозвільна система, а також встановлює порядок виготовлення, придбання, зберігання, обліку, охорони, перевезення, використання таких предметів, матеріалів і речовин, відкриття підприємств, майстерень і лабораторій; постанова Кабінету Міністрів України “Про порядок продажу, придбання, реєстрації, обліку і застосування спеціальних засобів самооборони, заряджених речовинами сльозоточивої та дратівної дії” від 7 вересня 1993 р. № 706, якою затверджено Положення, яке визначає порядок виготовлення, реалізації (продажу) суб'єктами підприємницької діяльності спеціальних засобів самооборони, заряджених речовинами сльозоточивої та дратівної дії, а також їх придбання, реєстрації, обліку, зберігання (носіння) і застосування громадянами

DOI (Article): https://doi.org/10.36486/np.2019.2.11

(C) Tsyhanov Oleh, 2019 
та юридичними особами; постанова Кабінету Міністрів України “Про затвердження переліку платних послуг, які надаються підрозділами Міністерства внутрішніх справ, Національної поліції та Державної міграційної служби, і розміру плати за їх надання” від 4 червня 2007 р. № 795, якою затверджено в тому числі перелік платних адміністративних послуг, які надаються підрозділами Національної поліції України, та розмір плати за їх надання; постанова Кабінету Міністрів України “Деякі питання надання підрозділами Міністерства внутрішніх справ, Національної поліції та Державної міграційної служби платних послуг” від 26 жовтня 2011 р. № 1098, якою затверджено порядок надання підрозділами, в тому числі Національної поліції України, платних адміністративних послуг фізичним і юридичним особам; постанова Кабінету Міністрів України "Про затвердження Положення про Національну поліцію” від 28 жовтня 2015 р. № 877, котрим затверджено Положення, у п. 4 якого визначені основні повноваження поліції, в тому числі щодо надання окремих адміністративних послуг, що фактично дублюють відповідні положення розглянутого нами Закону України “Про Національну поліцію”; наказ МВС України "Про затвердження Інструкції про порядок виготовлення, придбання, зберігання, обліку, перевезення та використання вогнепальної, пневматичної і холодної зброї, пристроїв вітчизняного виробництва для відстрілу патронів, споряджених гумовими чи аналогічними за своїми властивостями метальними снарядами несмертельної дії, та зазначених патронів, а також боєприпасів до зброї та вибухових матеріалів” від 21 серпня 1998 р. № 622; наказ МВС України "Про реалізацію повноважень Національної поліції України з видачі та анулювання дозволів” від 29 грудня 2015 р. № 1644; спільний наказ МВС України та Мінфіну України “Про затвердження Порядку зарахування до бюджетів плати за надання адміністративних послуг та продукцію і документи, що використовуються для оформлення цих послуг” від 12 лютого 2016 р. № 96/55 та деякі інші.

Наступним видом поліцейських послуг є інформащійні поліщейські послуги. Зазначимо, що правову основу інформаційних відносин, що виникають у процесі обміну, одержання, використання, зберігання та споживання інформації, складають Конституція України, Закон України “Про інформацію” від 2 жовтня 1992 р. № 2657 XII, Закон України "Про доступ до публічної інформації” від 13 січня 2011 р. № 2939-VI, а також інші законодавчі та підзаконні акти.

Згідно 3 ч. 1 ст. 23 Закону України “Про інформацію” інформаційною послугою є діяльність з надання інформаційної продукції споживачам з метою задоволення їхніх потреб [2]. Окремі положення Закону України “Про Національну поліцію” визначають питання щодо повноважень поліції у сфері інформаційноаналітичного забезпечення (ст. 25), формування поліцією інформаційних ресурсів (ст. 26), використання зазначених ресурсів (ст. 27), а також відповідальності за їх протиправне використання (ст. 28) [3]. Відповідно до п. 16 Положення про Департамент інформаційно-аналітичної підтримки Національної поліції України, затвердженого наказом Національної поліції України від 11 жовтня 2017 р. № 1060, на цей підрозділ покладається інформаційне забезпечення також зовнішніх (за межами системи Національної поліції України) споживачів.

Під охоронною діяльністю згідно з абз. 2 ст. 1 Закону України “Про охоронну діяльність” від 22 березня 2012 р. № 4616-VI розуміється надання послуг з охорони власності та громадян [4].

DOI (Article): https://doi.org/10.36486/np.2019.2.11

(c) Tsyhanov Oleh, 2019 
До повноважень Національної поліції України відповідно до покладених на неї завдань віднесено, зокрема: 1) здійснення охорони об’єктів права державної власності у випадках та порядку, визначених законом та іншими нормативноправовими актами, а також узяття участі у здійсненні державної охорони [3, п. 19 ч. 1 ст. 23]; 2) здійснення на договірних засадах охорони фізичних осіб та об’єктів права приватної і комунальної власності [3, п. 20 ч. 1 ст. 23].

Отже, охоронна поліцейська діяльність передбачає надання охоронних послуг, у тому числі й на договірних засадах, забезпечення особистої безпеки фізичних осіб, а також охорону майна фізичних і юридичних осіб, насамперед об'єктів (обмежених територій, будівель, споруд тощо), транспортних засобів, вантажів, грошових знаків (цінних паперів) тощо.

Постановою Кабінету Міністрів України “Питання функціонування органів поліції охорони як територіальних органів Національної поліції та ліквідації деяких територіальних органів Міністерства внутрішніх справ” від 13 жовтня 2015 р. № 834 утворені як юридичні особи публічного права органи поліції охорони й установлено, що зазначені органи, створені як територіальні органи Національної поліції, є правонаступниками Департаменту Державної служби охорони при Міністерстві внутрішніх справ та відповідних державних установ Державної служби охорони при Міністерстві внутрішніх справ, що ліквідовувалися в установленому законодавством порядку [5].

Правовою основою діяльності поліції охорони є також такі нормативноправові акти: Конституція України, Закон України від 22 березня 2012 р. № 4616VI “Про охоронну діяльність”, постанова Кабінету Міністрів України від 10 серпня 1993 р. № 615 “Про заходи щодо вдосконалення охорони об’єктів державної та інших форм власності”, постанова Кабінету Міністрів України від 4 березня 2015 р. № 83 “Про затвердження переліку об’єктів державної власності, що мають стратегічне значення для економіки і безпеки держави”, постанова Кабінету Мiністрів України від 11 листопада 2015 р. № 937 “Питання забезпечення охорони об’єктів державної та інших форм власності", наказ МВС України “Про організацію службової діяльності поліції охорони з питань забезпечення фізичної охорони об’єктів” від 7 липня 2017 р. № 577, наказ Національної поліції України від 6 листопада 2015 р. № 43 “Про затвердження Положення про Департамент поліції охорони" тощо.

Наразі поліцією охорони надаються послуги, які передбачають:

1) охорону об’єктів права державної власності у випадках та порядку, визначених законом та іншими нормативно-правовими актами, а також участь у здійсненні державної охорони: а) вантажів і цінностей; б) міжбанківських перевезень; в) разових публічних заходів;

2) охорону фізичних осіб та об'єктів права приватної і комунальної власності на договірних засадах: а) фізичних осіб; б) туристичних груп; в) майнової безпеки як українців, так й іноземних громадян; г) разових заходів.

Водночас із зазначених вище охоронних послуг слід виділити специфічні охоронні поліцейські послуги, такі як: 1) охорона автотранспорту та вантажоперевезень, під якою розуміється спостереження за рухомими об'єктами з використанням технологій супутникової навігації GPS, мережі GSM-900/1800 та

DOI (Article): https://doi.org/10.36486/np.2019.2.11

(c) Tsyhanov Oleh, 2019 
радіозв'язку на всій території України та поза іï межами; 2) охорона перевезення цінностей банківським та фінансовим установам, підприємствам інших форм власності, яка здійснюється на всій території України як власними броньованими автомашинами поліції охорони, так і транспортними засобами замовника.

Слід зазначити, що Перелік платних послуг, які надаються підрозділами Міністерства внутрішніх справ, Національної поліції та Державної міграційної служби, і розміру плати за їх надання, затверджений постановою Кабінету Міністрів України від 4 червня 2007 р. № 795, містить також інші поліщейські послуги, надання яких здійснюється підрозділами Національної поліції України, як-от:

1) забезпечення супроводження для безпечного перевезення негабаритних, великовагових та небезпечних вантажів, автобусів та інших транспортних засобів спеціалізованими автомобілями Національної поліції з використанням спеціальних світлових або звукових сигналів;

2) обстеження з виїздом на місце території або окремих ділянок автомобільних доріг, вулиць і залізничних переїздів, на яких планується розміщення об'єктів дорожнього сервісу, малих архітектурних форм; ділянок вулично-дорожньої мережі, на яких планується відкриття нових або перегляд діючих маршрутів руху транспортних засобів, залучених до перевезення пасажирів;

3) підготовка і видача технічних умов на розміщення об'єкта дорожнього сервісу та малої архітектурної форми;

4) перевірка проектної документації щодо будівництва, реконструкції і ремонту автомобільних доріг, вулиць та залізничних переїздів, об'єктів дорожнього сервісу, інших дорожніх споруд; забудови окремих територій населених пунктів; генеральних планів окремих забудов у населених пунктах; проектів комплексних схем організації руху та спорудження ліній міського електричного транспорту; схем організації дорожнього руху на відповідність технічним умовам та нормативно-правовим актам з безпеки дорожнього руху з подальшим оформленням документів щодо її розгляду та затвердження з наданням погодження або відмови в наданні погодження;

5) доставка, зокрема з використанням спеціальних транспортних засобів, затриманих за порушення правил, норм і стандартів у сфері безпеки дорожнього руху або технічно несправних транспортних засобів до визначеного замовником місця їх зберігання [6].

Із назв цих послуг зрозуміло, що надаються вони підрозділами Національної поліції України відповідно до законодавства України у сфері безпеки дорожнього руху (зокрема: Закону України від 30 червня 1993 р. № 3353-XII “Про дорожній рух", постанови Кабінету Міністрів України від 10 жовтня 2001 р. № 1306 "Про правила дорожнього руху” тощо), а також згідно з інструкціями, затвердженими відповідними наказами МВС України та Національної поліції України.

Таким чином, проведений аналіз наукової літератури та чинного законодавства України у сфері поліцейської діяльності дозволяє констатувати, що погляди фахівців на правову природу поліцейської послуги та іï̈ місце у вітчизняній соціальній практиці поділяються за двома проблемними напрямами: 1) відмежування поліцейських послуг від інших завдань поліції та 2) відмежування поліцейської послуги від інших видів публічних послуг.

DOI (Article): https://doi.org/10.36486/np.2019.2.11

(C) Tsyhanov Oleh, 2019 
На наше переконання, однією з найбільш характерних ознак поліцейської послуги, як і будь-якої іншої послуги, є первинність потреб замовника цієї послуги у діях її надавача, а також індивідуальний характер надання такої послуги фізичній чи юридичній особі, яка має на це право. Разом із поліцейськими заходами поліцейські послуги являють собою одну з основних форм поліцейської діяльності. Відповідно до змісту здійснюваної діяльності послуги, що надаються органами та підрозділами Національної поліції України, можна розподілити на: 1) адміністративні; 2) інформаційні; 3) охоронні та 4) інші поліцейські послуги.

\section{СПИСОК ВИКОРИСТАНИХ ДЖЕРЕЛ}

1. Про адміністративні послуги: Закон України від 6 вересня 2012 р. № 5203-VI. Офіційний вісник України. 2012. № 76. Ст. 3067.

2. Про інформацію: Закон України від 2 жовтня 1992 р. № 2657-ХІ . Відомості Верховної Ради України. 1992. № 48. Ст. 550.

3. Про Національну поліцію: Закон України від 2 липня 2015 р. № 580-VIII. Відомості Верховної Ради України. 2015. № 40-41. Ст. 379.

4. Про охоронну діяльність: Закон України від 22 березня 2012 р. № 4616-VI. Офіційний вісник України від 27.04.2012 . № 30. Ст. 1099.

5. Питання функціонування органів поліції охорони як територіальних органів Національної поліції та ліквідації деяких територіальних органів Міністерства внутрішніх справ: постанова Кабінету Міністрів України від 13 жовтня 2015 р. № 834. Офіційний вісник України від 30.10.2015. № 84. Ст. 2814.

6. Про затвердження переліку платних послуг, які надаються підрозділами Міністерства внутрішніх справ, Національної поліції та Державної міграційної служби, і розміру плати за їх надання: постанова Кабінету Міністрів України від 4 червня 2007 р. № 795. Офіційний вісник України. 2007. № 42. Ст. 1671.

\section{REFERENCES}

1. Pro administratyvni posluhy. "On Administrative Services": Law of Ukraine of September 6, 2012 No. 5203-VI. Official Bulletin of Ukraine. 2012. No 76. Art. 3067 [in Ukrainian].

2. Pro informatsiiu. "About information": Law of Ukraine of October 2, 1992 No. 2657-XI. Information of the Verkhovna Rada of Ukraine. 1992. No. 48. Art. 550 [in Ukrainian].

3. Pro Natsionalnu politsiiu. "On the National Police": Law of Ukraine of July 2, 2015 No. 580-VIII. Information of the Verkhovna Rada of Ukraine. 2015. No 40-41. Art. 379 [in Ukrainian].

4. Pro okhoronnu diialnist. "On security activities": Law of Ukraine of March 22, 2012 No. 4616-VI. Official Bulletin of Ukraine dated 27.04.2012. No. 30. Art. 1099 [in Ukrainian].

5. Pytannia funktsionuvannia orhaniv politsii okhorony yak terytorialnykh orhaniv Natsionalnoi politsii ta likvidatsii deiakykh terytorialnykh orhaniv Ministerstva vnutrishnikh sprav. "Issues of Functioning of Police Protection Bodies as Territorial Bodies of the National Police and Liquidation of Some Territorial Bodies of the Ministry of Internal Affairs": Resolution of the Cabinet of Ministers of Ukraine of October 13, 2015 No. 834. Official Bulletin of Ukraine dated 30.10.2015. No 84. Art. 2814 [in Ukrainian].

6. Pro zatverdzhennia pereliku platnykh posluh, yaki nadaiutsia pidrozdilamy Ministerstva vnutrishnikh sprav, Natsionalnoi politsii ta Derzhavnoi mihratsiinoi sluzhby, i rozmiru platy za yikh nadannia. "On approval of the list of paid services provided by the departments of the Ministry of Internal Affairs, National Police and State Migration Service, and the amount of payment for their provision": Resolution of the Cabinet of Ministers of Ukraine of June 4, 2007 No. 795. Official Bulletin of Ukraine. 2007. No 42. Art. 1671 [in Ukrainian].

DOI (Article): https://doi.org/10.36486/np.2019.2.11

(C) Tsyhanov Oleh, 2019 Issue 2(4.4) 2019 http://naukaipravoohorona.com/ 
UDC 351.741

\author{
Tsyhanov Oleh, \\ Doctor of Juridical Sciences, Associate Professor, \\ Chief Researcher of Research Laboratory, \\ State Research Institute MIA Ukraine, \\ Kyiv, Ukraine, \\ ORCID ID 0000-0002-8924-1139
}

\title{
TYPES OF POLICE SERVICE IN UKRAINE AND ORGANIZATIONAL-LEGAL SUPPLY OF THEIR PROVISION
}

The article is devoted to the disclosure of the main types of police services in Ukraine and the description of the organizational and legal supply of their provision. It is noted that today the service factor becomes a decisive symbol of the organs of public power of Ukraine, including the newly created law-enforcement body created on the grounds of the liquidated police - the National Police of Ukraine. However, in spite of the lengthy discussions on the meaningful interpretation of such a type of public service as a police service, neither in the academic circles nor in the circles of practitioners a single approach to understanding the essence of this phenomenon has yet been formed. The article notes that one of the most characteristic features of the police service, like any other service, is the primacy of the needs of the customer for this service in the actions of its provider, as well as the individual nature of the provision of such a service to a natural or legal person who has this right.

Police services along with police measures are one of the main forms of police activity, the main types of which should include: 1) administrative police activities; 2) criminal-procedural police activity; 3) police activity of operational search units; 4) information-analytical police activity; 5) security police activities. The author defines the concept of "police service" and, in terms of policing in Ukraine, divides these services into four groups: 1) administrative; 2) information; 3) security and 4) other police services. For each group of police services, the organizational and legal provision of their provision is described in detail.

The fulfillment of a large part of the duties of the police authorities to private persons is related to such an important direction of their activities as the provision of administrative services. The administrative police service should be understood as the publicly-authorized activity of a police body (unit), provided by the law, carried out on the application of a natural or legal person to create organizational conditions for the realization of his rights, freedoms and legal interests and/or the implementation of duties assigned to him by law in the field of activity of the National Police of Ukraine, by adopting and documenting the corresponding administrative act, which has an individual appointment and an external sphere of application.

Keywords: public service activities, police activities, police services.

Отримано 07.06.2019

DOI (Article): https://doi.org/10.36486/np.2019.2.11

(C) Tsyhanov Oleh, 2019 
DOI (Issue): https://doi.org/10.36486/np.2019.2

Issue 2(4-4) 2019

\title{
КРИМІНАЛЬНЕ ПРАВО ТА КРИМІНОЛОГІЯ. КРИМІНАЛЬНО-ВИКОНАВЧЕ ПРАВО
}

УДК 343.98(477)

\author{
Дрозд Валентина Георгіївна, \\ доктор юридичних наук, доцент, \\ старший науковий співробітник, \\ провідний науковий співробітник \\ ДНДІ МВС України м. Київ, Україна \\ ORCID ID 0000-0002-7687-7138
}

\section{НЕДОПУСТИМІСТЬ РОЗГОЛОШЕННЯ ВІДОМОСТЕЙ ДОСУДОВОГО РОЗСЛІДУВАННЯ ЯК УМОВА ДОСЯГНЕННЯ ЗАВДАНЬ КРИМІНАЛЬНОГО ПРОВАДЖЕННЯ}

Статтю присвячено актуальним питанням регламентацї інституту нерозголошення відомостей досудового розслідування як однієї з умов ефективного досягнення завдань кримінального провадження. Зазначається, що чинний КПК Украӥни передбачає особливий порядок розголошення відомостей досудового розслідування, а також містить бланкетні норми-санкцї у випадку порушення встановлених вимог. Наголошено, що такі відомості досудового розслідування, як інформація, є таємними, через що доступ до них обмежено з метою недопущення спричинення шкоди учасникам кримінального провадження. 3 урахуванням проведеного дослідження запропоновані відповідні зміни й доповнення до чинного законодавства.

Ключові слова: кримінальне провадження, таємниия досудового розслідування, нерозголошення відомостей досудового розслідування, інформащія з обмеженим доступом.

Ефективність виконання завдань кримінального провадження досить часто залежить від недопущення вчинення протиправних дій, які можуть зашкодити досудовому розслідуванню. В цьому контексті невід’ємним “запобіжником” є процесуальний інститут нерозголошення відомостей досудового розслідування, який регламентується ст. 222 КПК України. Водночас, незважаючи на його вагомість, слід констатувати недостатність наукової розробленості відповідних приписів та фрагментарність наукових досліджень із цього питання, а подекуди й відсутність чіткого законодавчого регулювання у визначеному напрямі та неузгодженість понятійного апарату. Першочерговою проблемою, що зумовлює плутанину в одноманітному розумінні нерозголошення відомостей досудового розслідування, є відсутність нормативно-правового визначення цього поняття та єдиної класифікації інформаційних ресурсів з обмеженим доступом.

DOI (Article): https://doi.org/1.36486/np.2019.2.12

(C) Drozd Valentyna, 2019 Issue 2(44) 2019 http://naukaipravoohorona.com/ 
Окремим науковим та прикладним питанням недопустимості нерозголошення відомостей досудового розслідування присвятили свої праці О.В. Гриза, Р.В. Бараннік, О.А. Ляш, П.Г. Назаренко, О.А. Осауленко, О.В. Курман, О.І. Марочкін, Н.І. Полонова, В.В. Павловський, А.З. Якубовата та інші вчені. Однак чимало проблемних законодавчих аспектів, що стосуються недопустимості розголошення відомостей досудового розслідування (інституту таємниці досудового розслідування), залишаються невирішеними. У зв'язку з цим у практичній площині виникають складнощі щодо одноманітного застосування законодавчих вимог у цьому напрямі діяльності.

Мета статті полягає в аналізі законодавчих положень, що регламентують нерозголошення відомостей досудового розслідування, виявлення проблемних аспектів унормування цього інституту та формування відповідних пропозицій з його вдосконалення.

На основі проведеного соціологічного дослідження О.В. Гриза зазначає, що 70 \% респондентів наголосили на необхідності роз'яснення додержання таємниці досудового розслідування. Водночас 30 \% указали на відсутність у своїй практиці правозастосування положень ст. 222 КПК України або на поодинокість іх застосування без письмового роз'яснення обов’язку нерозголошення даних досудового розслідування та попередження про кримінальну відповідальність за ст. 387 КК України [1, с. 201; 2]. На доцільність застосування вимог ст. 222 КПК України вказали й 84 \% опитаних нами слідчих Національної поліції та 89 \% прокурорів. Така необхідність, як слушно відзначає А.З. Якубова, пов'язана з можливістю зацікавлених осіб перешкодити встановленню обставин кримінального правопорушення, скомпрометувати особу, яка бере участь у кримінальному провадженні [3, с. 201].

Чинний КПК України передбачає особливий порядок розголошення відомостей досудового розслідування, а також містить бланкетні норми-санкції у випадку порушення встановленої КПК України моделі відповідних процесуальних відносин. На нашу думку, саме слово “відомості" є предикатом поняття інформації, яке міститься в ч. 1 ст. 1 Закону України “Про інформацію”. У ч. 1 ст. 21 цього Закону надано класифікацію інформації, зокрема з обмеженим доступом, яка поділяється на конфіденційну, таємну та службову інформацію (у цій статті також розкрито поняття конфіденційної інформації) [4].

У статті 8 Закону України “Про доступ до публічної інформації” розкрито поняття таємної інформації, під якою розуміється інформація, доступ до якої обмежується, розголошення якої може завдати шкоди особі, суспільству і державі. Таємною визнається інформація, яка містить державну, професійну, банківську таємницю, таємницю досудового розслідування та іншу, передбачену законом таємницю [5]. Тобто такі відомості досудового розслідування, як інформація, є таємними, через що доступ до них обмежено з метою недопущення спричинення шкоди учасникам кримінального провадження, наприклад, розголошення відомостей про особисте та сімейне життя, комерційну діяльність особи тощо. Водночас залишаються незрозумілими зміст і обсяг самого поняття "відомості досудового розслідування".

DOI (Article): https://doi.org/1.36486/np.2019.2.12

(c) Drozd Valentyna, 2019 
Досліджуючи види таємної інформації, можна побачити, що законодавець у “суміжних” правовідносинах надає більш чітке регулювання понятійного апарату та критеріїв віднесення інформації до певного виду таємної інформації. Так, у ст. 60 Закону України “Про банки і банківську діяльність” під банківською таємницею розуміється інформація щодо діяльності та фінансового стану клієнта, яка стала відомою банку в процесі обслуговування клієнта та взаємовідносин з ним чи третіми особами при наданні послуг банку. Також відповідна норма надає критерії щодо визначення інформації як банківської таємниці [6]. Схожий підхід до регулювання державної таємниці спостерігається в положеннях статей 1, 8 Закону України "Про державну таємницю”, де визначено поняття та види інформації, яка є державною таємницею [7]. Аналогічно в ст. 8 Закону України "Про нотаріат" розкрито поняття “нотаріальна таємниця" [8]. Залишається незрозумілим, чому у сфері кримінального судочинства законодавець нормативно не врегулював це питання.

Аналізуючи доктринальні напрацювання щодо проблемних питань нерозголошення відомостей досудового розслідування, можна виділити два основні напрями, на які спрямовані наукові пошуки дослідників:

1. Дослідження особливостей кримінального прочесуального регулювання інституту нерозголошення відомостей досудового розслідування. У цьому напрямі окремі науковці, зокрема Р.В. Бараннік, О.А. Ляш, П.Г. Назаренко тощо, аналізуючи відповідне законодавство, вказують на недоліки регулювання питань щодо нерозголошення відомостей досудового розслідування та надають пропозиції стосовно їх вирішення [9, с. 197]. Говорячи про відповідний напрям дослідження, необхідно вказати на те, що під час досудового розслідування сторона обвинувачення на підставі зібраних доказів встановлює обставини, що мають значення для кримінального провадження, та долучає фактичні дані, які за своєю суттю вже є інформацією 3 обмеженим доступом. Наприклад, при розслідуванні господарських або корупційних злочинів до матеріалів провадження долучаються документи, що становлять банківську таємницю. Також зазвичай здійснюється доступ і перегляд кореспонденції, інформація в якій може належати до конфіденційної. Таким чином, розглядаючи таємницю досудового розслідування, насамперед варто усвідомлювати, що матеріали провадження можуть містити низку іншої інформації, яка є обмеженою в доступі, що й зумовлює питання щодо порядку та підстав її розголошення в межах кримінального провадження.

2. Дослідження організачійних аспектів прочесуальної діяльності сторони обвинувачення та правоохоронних органів загалом. Інші ж науковці, зокрема О.В. Гриза, О.А. Осауленко тощо, у своїх дослідженнях вивчають особливості організаційних питань процесуальної діяльності слідчого, прокурора, працівників правоохоронних органів щодо недопущення розголошення відомостей досудового розслідування, виявляють та надають вирішення проблем, причини яких випливають із організаційних, а також службових аспектів їх діяльності [1, с. 231].

Грунтуючись на дослідженнях зазначених науковців, слід з'ясувати сутність поняття “таємниця досудового розслідування”, яке вживається в ст. 8 Закону України “Про доступ до публічної інформації” і є базовим поняттям для ст. 220 КПК України. На думку О.В. Курмана, під цією дефініцією слід розуміти відомості

DOI (Article): https://doi.org/1.36486/np.2019.2.12

(c) Drozd Valentyna, 2019 
стосовно результатів слідчих (розшукових) дій, оперативно-розшукових заходів, експертних досліджень про осіб, події, процеси, тактику та методи проведення процесуальних дій, розголошення яких може негативно вплинути на всебічність, повноту й неупередженість розслідування кримінального правопорушення. Як убачається з наведеного, автор намагається це поняття розглядати як службову інформацію [10, с. 176-177], з чим ми повною мірою не можемо погодитися, оскільки, виходячи з положень вказаних вище нормативно-правових актів, таємниця досудового розслідування, як інформація, належить до таємної інформації.

Як зазначає O.I. Марочкін, інформація, отримана під час досудового розслідування, становить його таємницю, під якою у теорії кримінального процесу прийнято розуміти охоронювану кримінальним процесуальним та кримінальним законом інформацію (відомості), спрямовану на забезпечення інтересів слідства у кримінальному провадженні. Конфіденційність такої інформації, виходячи із положень ст. 222 КПК, визначається слідчим або прокурором та захищається 3 метою попередження завдання шкоди інтересам досудового слідства в цілому, а також інтересам особистості, суспільства та держави [11, с. 295].

У контексті порушеного питання варто звернути увагу на дослідження H.I. Полонової, яка, розглядаючи загальні особливості таємниці, надає характерні ознаки (риси) таємниці досудового розслідування: по-перше, таємність інформації, що охороняється правовласником від доступу до неї третіх осіб; по-друге, шкода, яка може бути спричинена правовласникові внаслідок розголошення указаної інформації; по-третє, осуд осіб, які вчинили розголошення інформації третім особам [12, с. $138-139]$.

На недосконалості законодавчого регулювання вказаного питання наголошує також О.А. Осауленко. Зокрема, автор указав на неузгодженість законодавства про інформацію та положень ст. 222 КПК України, зокрема щодо процесуальної можливості слідчого, прокурора визначати обсяг і характер відомостей, які підлягають або не підлягають розголошенню. 3 огляду на це вчений ставить досить обгрунтовані питання: по-перше, які відомості досудового розслідування можна розголошувати; по-друге, яка форма отримання відповідного дозволу на розголошення відомостей учасником кримінального провадження, який є їх фактичним власником? [13, с. 189].

Водночас деякі науковці піддають критиці такий підхід і вважають його невірним, оскільки вбачають у відповідному інституті механізм із чітко окресленими елементами. Так, І.В. Кутазова та А.О. Ляш надають структуру кримінального процесуального забезпечення недопустимості розголошення даних кримінального судочинства, куди включають такі елементи, як: 1) кримінальні процесуальні норми, які регулюють відкритість і закритість кримінального процесу з метою забезпечення недопустимості розголошення даних; 2) відповідні правовідносини; 3) правосвідомість, тобто ставлення учасників до відповідного обов'язку; 4) процесуально оформлене рішення в межах нерозголошення відомостей досудового розслідування; 5) юридична відповідальність за порушення обов'язку не розголошувати відомості досудового розслідування [14, с. 9, 13-15; 15, с. 6].

Доповнює висвітлену тематику О.В. Гриза, який, на наше переконання, досить вірно надає критерії відомостей, що охоплюють поняття таємниці досудового

DOI (Article): https://doi.org/1.36486/np.2019.2.12

(c) Drozd Valentyna, 2019 Issue 2(44) 2019 http://naukaipravoohorona.com/ 
розслідування. До них науковець відніс: наявність процесуального права особи у доступі до таких відомостей; здатність відомостей досудового розслідування після їх розголошення ганьбити людину, принижувати її честь і гідність; здатність відомостей досудового розслідування після їх розголошення зашкодити повноті й неупередженості розслідування; дані про застосування заходів безпеки; належність інформації до іншого виду охоронюваної законом таємниці [1, с. 204].

Досить слушними є також зауваження В.В. Павловського, який указує на некоректність понятійного апарату ст. 222 КПК України, де законодавець використовує термін “відомості досудового розслідування" та положення ст. 387 КПК України щодо недопустимості розголошення “даних досудового розслідування” [16, с. 165]. 3 таким твердженням варто погодитись, хоча, на нашу думку, ця законодавча неточність не тягне за собою значних правозастосовних наслідків, однак є помилкою юридичної техніки, що може негативно вплинути на практичне застосування відповідних норм.

Продовжуючи дискусію, слід наголосити, що таємниця, яка стосується відомостей досудового розслідування, ще не означає, що його проведення здійснюється негласно. Пояснюється це тим, що в ст. 93 КПК України передбачені й інші способи збирання доказів. Говорячи про негласні слідчі (розшукові) дії, виходячи 3 ч. 1 ст. 246 КПК України, слід указати, що відомості про факт та методи проведення негласних слідчих (розшукових) дій не підлягають розголошенню, за винятком випадків, передбачених КПК України. Досить влучно із цього приводу говорить А.З. Якубова, вказуючи, що закріплення положень ст. 220 КПК України не означає абсолютну негласність проведення досудового розслідування. Навпаки, автор зауважує, що гласність досудового розслідування полягає в обов’язковій участі передбачених кримінальним процесуальним законодавством суб'єктів [3, с. 201]. Така наукова позиція видається вірною та виражається, наприклад, у відкритому судовому засіданні під час обрання підозрюваному запобіжного заходу, де передбачена присутність осіб, які не наділені кримінальними процесуальними обов’язками, наприклад журналісти чи громадськість. Крім того, досить часто у випадку вчинення злочину, що набув особливого суспільного резонансу, керівник органу досудового розслідування або керівник територіального органу, до якого входить орган досудового розслідування, звітують перед громадськістю про результати проведеного розслідування, під час чого вказують на докази, що підтверджують вину підозрюваного.

Також актуальним залишається питання стосовно розголошення даних досудового розслідування через засоби масової інформації. Наразі все частіше під час телевізійного ефіру інформаційних програм висвітлюються відомості досудового розслідування з посиланням на “свої джерела” в правоохоронних органах. Слід зазначити, що при розслідуванні господарських злочинів або злочинів, де доказовою базою виступають документи, сам факт розголошення наявності розпочатого досудового слідства у засобах масової інформації може призвести до умисного знищення зацікавленими особами документів, необхідних для доведення вини особи.

Як зазначають В.В. Бараннік та П.Г. Назаренко, засоби масової інформації досить часто, трактуючи діяльність правоохоронних органів, висвітлюють інформацію, доступ до якої обмежено законодавцем [9, с. 16]. Дійсно, навіть незважаючи

DOI (Article): https://doi.org/1.36486/np.2019.2.12

(c) Drozd Valentyna, 2019 
на той факт, що громадський контроль за діяльністю правоохоронних органів є одним із ефективних засобів щодо недопущення зловживання владою та вчинення інших правопорушень, все ж таки у пошуках чергових сенсацій журналісти не повинні допускати розголошення інформації з обмеженим доступом, у тому числі відомостей досудового розслідування.

Дискусійним аспектом законодавчого регулювання залишається питання стосовно процесуальної форми отримання від слідчого та прокурора дозволу на розголошення відомостей досудового розслідування. Зазначене зумовлене лише вказівкою на “з письмового дозволу”, через що й виникає питання про те, має це бути окремий протокол, розписка чи якийсь інший документ. При розгляді цього питання наукова спільнота висловлює дві позиції. Одні науковці (О.А. Ляш, А.З. Якубова) підтримують протокольну форму роз'яснення положень законодавства з приводу недопустимості розголошення учасниками кримінального провадження відомостей досудового розслідування та попередження про кримінальну відповідальність у випадку невиконання відповідних вимог [15; 3]. Водночас О.А. Осауленко аргументує неприпустимість оформлення згоди слідчого, прокурора або роз'яснення недопустимості розголошення відомостей досудового розслідування, складаючи протокол [13].

Як вважає В.В. Павловський, у випадку застосування кримінального процесуального законодавства в частині нерозголошення відомостей досудового розслідування доцільно використовувати протокольну форму оформлення відповідної процесуальної дії. Зокрема, це може бути здійснено в протоколі проведення слідчої (розшукової) дії або використаний спеціально призначений протокол, оскільки письмова форма забезпечить можливість вирішення питання про відповідальність винуватих у розголошенні даних досудового розслідування осіб [16, с. 166].

Водночас О.А. Осауленко зауважує, що зазначена вище позиція є сумнівною, оскільки КПК України не передбачає фіксацію дискусійної процесуальної дії у протокольній формі, вказуючи, що під час проведення обшуку чи огляду кримінальний процесуальний закон надає пряму вказівку на складання протоколу слідчої розшукової дії [13, с. 190]. 3 такою позицією ми не можемо погодитись, адже в положенні ч. 1 ст. 104 КПК України вказано, що у випадках, передбачених КПК України, хід і результати проведення процесуальної дії фіксуються в протоколі. Незважаючи на те, що відповідна норма посилає на передбачені законом випадки складання протоколу, однак вказані положення, на нашу думку, не забороняють складання відповідного документа при проведенні інших процесуальних дій, а вказують на обов’язковість складання протоколу, якщо це передбачає кримінальний процесуальний закон. Ключовим аспектом у цьому питанні є не стільки форма, скільки сам письмовий документ, у якому зазначається, що особа, повідомлена про заборону розголошення таємниці досудового розслідування, також повідомлена про відповідальність за порушення положень ст. 221 КПК України. Проте різні учасники кримінального провадження мають неоднаковий доступ до матеріалів кримінального провадження. Зокрема свідок, якого допитує слідчий, не може отримати інформацію досудового розслідування за межами слідчої (розшукової) дії допиту, на відміну від потерпілого, наділеного правом на

DOI (Article): https://doi.org/1.36486/np.2019.2.12

(c) Drozd Valentyna, 2019 Issue 2(44) 2019 http://naukaipravoohorona.com/ 
ознайомлення з матеріалами кримінального провадження. У такому випадку при допиті свідка, на наше переконання, в протоколі допиту буде достатньо виділити графу про заборону розголошення відомостей досудового розслідування, які йому стали відомі під час слідчої (розшукової) дії. Розглядаючи варіант з ознайомленням із матеріалами досудового розслідування до його завершення, зокрема потерпілим, доречним буде складання окремого протоколу про роз'яснення заборони розголошення досудового розслідування.

Досить плідна дискусія ведеться науковцями щодо організаційних особливостей службової діяльності правоохоронних органів, зокрема щодо недопущення розголошення відомостей досудового розслідування. Цікаву позицію висловлює О.В. Гриза, що вказує на організацію праці, облаштування робочого місця слідчого, прокурора, що безпосередньо впливає на можливість збереження таємниці досудового розслідування, наголошуючи, що розміщення двох, трьох, а подекуди і чотирьох слідчих у службовому кабінеті може сприяти ситуації, коли слідчий буде допитувати осіб в одному приміщенні, а інші матимуть можливість слухати інформацію, дані про інші кримінальні провадження [17, с. 156].

Відповідний напрям доповнюється дослідженнями Р.В. Бараннік та П.Г. Назаренка, які наголошують на значенні особистих якостей слідчого, коли, наприклад, недбале ставлення до службових обов'язків, зокрема утримання матеріалів справи в столах службових кабінетів слідчих, неохайне зберігання матеріалів, поширення слідчими службової інформації в позаслужбовому, побутовому або службовому спілкуванні без належного дотримання вимог нерозголошення інформації, може призвести до негативних наслідків відносно результатів досудового розслідування [9, с. 16].

Погоджуючись із зазначеною тезою, додамо, що якісний аспект нерозголошення відомостей досудового розслідування залежить не тільки від слідчого, а й від багатьох осіб, які хоч і не є учасниками кримінального провадження, однак являються працівниками правоохоронних органів. Мова йде про керівників відділів поліції, до яких слідчий звертається у разі необхідності залучення до проведення слідчих (розшукових) дій працівників практичних підрозділів (наприклад, для проведення обшуку). Відтак належне ставлення до тактичних і процесуальних моментів нерозголошення відомостей досудового розслідування також стосується осіб, які не є безпосередніми учасниками кримінального провадження.

В іншій праці О.В. Гриза вказує на завантаженість слідчого кількістю кримінальних проваджень, що призводить до “автоматичності” проведення слідчої розшукової дії, неврахування усіх особливостей окремого злочину, особи злочинця, кількості зацікавлених осіб, “шаблонності” процесуальних дій, що, як наслідок, призводить до розголошення окремих аспектів кримінального провадження [1, c. 205]. Зазначене варто підтримати, однак ми категорично не погоджуємося з пропозицією дослідниці щодо створення в Єдиному реєстрі досудових розслідувань фільтра, який би обмежував навантаження слідчого до 30 кримінальних проваджень, оскільки таку пропозицію реалізувати технічно неможливо. В багатьох відділах поліції реєстрація вчинення кримінальних правопорушень за рік перебігає позначку 2 тис., а іноді й 3 тис. Нескладні математичні операції покажуть необхідність залучення для реалізації пропозиції О.В. Гризи значних кадрових ресурсів, що є досить витратно для держави в економічному аспекті.

DOI (Article): https://doi.org/1.36486/np.2019.2.12

(c) Drozd Valentyna, 2019 
На основі аналізу законодавства та напрацювань доктрини кримінального процесуального права пропонуємо такі зміни та доповнення до положень КПК України: змісту:

По-перше, доповнити частину 1 статті 3 КПК України пунктом 24-1 такого

“24-1) таємниця досудового розслідування - вид таємної інформації, яка охоплює відомості щодо діяльності органу досудового розслідування, прокуратури, оперативних підрозділів у межах кримінального провадження, а також результатів проведення процесуальних дій, застосування заходів забезпечення кримінального провадження, розголошення яких може негативно вплинути на всебічність, повноту та неупередженість розслідування".

По-друге, у назві та змісті статті 387 КК України замінити слово “дані” на слово “відомості".

По-третє, статтю 222 КПК України доповнити новою частиною 3 такого змісту:

“3. Розголошення інформації, яка обмежена в доступі, здійснюється в порядку, передбаченому законодавством щодо іï використання та доступу до неї інших осіб”.

Отже, можна стверджувати, що законодавче регулювання питання недопустимості розголошення відомостей досудового розслідування характеризується певними суперечностями, що негативно впливає на ефективність виконання завдань кримінального провадження. Отже, вважаємо, що запропоновані нами зміни сприятимуть оптимізації вирішення цього питання.

\section{СПИСОК ВИКОРИСТАНИХ ДЖЕРЕЛ}

1. Гриза О.В. Удосконалення застосування засобів і заходів збереження таємниці досудового розслідування. Вісник пенітенціарної асоціації України. 2017. № 2. С. 201-208.

2. Гриза O.B. Гарантії забезпечення дотримання таємниці досудового розслідування: дис. ... канд. юрид. наук: 12.00.09. Дніпропетровськ, 2017. 200 с.

3. Якубова А.З. Окремі кримінально-процесуальні аспекти недопустимості розголошення відомостей досудового розслідування. Вісник Луганського держ. ун-ту внут. справ імені Е.О. Дідоренка. 2013. № 3. С. 199-208.

4. Про інформацію: Закон України від 2 жовт. 1992 р. № 2657-ХІ. База даних “Законодавство України". Верховна Рада України: [сайт]. URL: http://zakon.rada.gov.ua/laws/show/2657-12 (дата звернення: 22.03.2019).

5. Про доступ до публічної інформації: Закон України від 13 січ. 2011 р. № 2939-VI. База даних “Законодавство України”. Верховна Рада України: [сайт]. URL: http://zakon.rada.gov.ua/ laws/show/2939-17 (дата звернення: 22.03.2019).

6. Про банки і банківську діяльність: Закон України від 7 груд. 2000 р. № 2121-III. База даних “Законодавство України”. Верховна Рада України: [сайт]. URL: http://zakon2.rada.gov.ua/ laws/show/2121-14/paran983\#n983 (дата звернення: 22.03.2019).

7. Про державну таємницю: Закон України від 21 січ. 1994 р. № 3855-XII. База даних “Законодавство України”. Верховна Рада України: [сайт]. URL: http://zakon2.rada.gov.ua/laws/ show/3855-12 (дата звернення: 22.03.2019).

8. Про нотаріат: Закон України від 2 верес. 1993 р. № 3425-XII. База даних “Законодавство України”. Верховна Рада України: [сайт]. URL: http://zakon5.rada.gov.ua/laws/show/3425-12 (дата звернення: 22.03.2019).

9. Бараннік Р.В., Назаренко П.Г. Особливості охорони інформації, що становить таємницю у кримінальному судочинстві. Адвокат. 2011. № 4(127). С. 15-18.

DOI (Article): https://doi.org/1.36486/np.2019.2.12

(c) Drozd Valentyna, 2019 
10. Курман О.В. Відомості, що становлять інформацію з обмеженим доступом як предмет злочинного посягання. Право і суспільство. 2016. № 5. С. 174-178.

11. Марочкін O.I. Норми міжнародного права та рішення Європейського суду з прав людини про доступ до таємниці слідства. Правове забезпечення оперативно-службової діяльності: актуальні проблеми та шляхи їх вирішення: матеріали постійно діючого наук.-практ. семінару, м. Харків, 27 трав. 2016 року / [редкол.: С.О. Гриненко (голов. ред.) та ін.]. Харків, 2016. Вип. 7. С. 294-297.

12. Полонова H.I. Місце таємниці досудового розслідування серед інших таємниць, охоронюваних законом про кримінальну відповідальність. Юридичний науковий електронний журнал. 2017. № 2. C. 138-141. URL: http://lsej.org.ua j_2_2017.pdf (дата звернення: 22.03.2019).

13. Осауленко О.А. Кримінальні процесуальні гарантії нерозголошення відомостей досудового розслідування. Юридична наука. 2015. № 7. С. 185-193.

14. Кутазова И.В. Механизм уголовно-процессуального обеспечения недопустимости разглашения данных уголовного судопроизводства: автореф. дис. ... канд. юрид. наук: 12.00.09. Тюмень, 2011. 24 с.

15. Лящ А.О. Недопустимість розголошення відомостей досудового розслідування. Часопис Національного університету “Острозька академія”. 2013. № 1(7). С. 1-14.

16. Павловський B.B. Теоретичні та практичні проблеми забезпечення недопустимості розголошення відомостей досудового розслідування. Науковий вісник Міжнародного гуманітарного університету. Серія: Юриспруденція. 2014. № 12. Т. 2. С. 164-166.

17. Гриза О.B. Проблемні питання збереження таємниці досудового розслідування: сучасний стан та перспективи. Науковий вісник публічного та приватного права. 2016. Вип. 6. Т. 2. C. $153-158$.

\section{REFERENCES}

1. Hryza O.V. (2017) Udoskonalennia zastosuvannia zasobiv i zakhodiv zberezhennia taiemnytsi dosudovoho rozsliduvannia. "Improving the application of the means and measures of secrecy of pretrial investigation”. Bulletin of the Penitentiary Association of Ukraine. № 2. 201-208 pp. [in Ukrainian].

2. Hryza O.V. (2017) Harantii zabezpechennia dotrymannia tayemnytsi dosudovoho rozsliduvannia. "Guarantees of secrecy of pre-trial investigation: dis. Ph. D.: 12.00.09. Dnepropetrovsk. 200 p. [in Ukrainian].

3. Yakubova A.Z. (2013) Okremi kryminalno-protsesualni aspekty nedopustymosti rozholoshennia vidomostey dosudovoho rozsliduvannia. "Some criminal procedural aspects of inadmissibility of disclosure of information of pre-trial investigation". Bulletin of the Lugansk State un-te of E.O. Didorenko. No. 3. 199-208 pp. [in Ukrainian].

4. Pro informatsiiu: Zakon Ukrainy vid 02 zhovt. 1992 r. № 2657-XI. Baza danykh “Zakonodavstvo Ukrainy". "About information": Law of Ukraine of 02 October. 1992, No. 2657-XI. Database "Legislation of Ukraine". The Verkhovna Rada of Ukraine: [website]. URL: http://zakon.rada.gov.ua/laws/show/ 2657-12 (date of application: 22.03.2019) [in Ukrainian].

5. Pro dostup do publichnoi informatsii: Zakon Ukrainy vid 13 sich. 2011 r. № 2939-VI. Baza danykh "Zakonodavstvo Ukrainy". "On Access to Public Information": The Law of Ukraine of 13 January. 2011 No. 2939-VI. Database "Legislation of Ukraine". The Verkhovna Rada of Ukraine: [website]. URL: http://zakon.rada.gov.ua/laws/show/2939-17 (date of application: 22.03.2019) [in Ukrainian].

6. Pro banky i bankivsku diialnist: Zakon Ukrainy vid 07 hrud. 2000 r. № 2121-III. Baza danykh "Zakonodavstvo Ukrainy". "On Banks and Banking": Law of Ukraine of 07 Dec. 2000 No. 2121-III. Database "Legislation of Ukraine". The Verkhovna Rada of Ukraine: [website]. URL: http://zakon2.rada.gov.ua/laws/show/2121-14/paran983\#n983 (date of application: 22.03.2019) [in Ukrainian].

7. Pro derzhavnu taiemnytsyu: Zakon Ukrainy vid 21 sich. 1994 r. № 3855-XII. Baza danykh "Zakonodavstvo Ukrainy". "On State Secrets": Law of Ukraine of 21 January. 1994, No. 3855-XII. Database "Legislation of Ukraine". The Verkhovna Rada of Ukraine: [website]. URL: http:// zakon2.rada.gov.ua/laws/show/3855-12 (date of application: 22.03.2019) [in Ukrainian].

8. Pro notariat: Zakon Ukrainy vid 2 veres. 1993 r. № 3425-XII. Baza danykh “Zakonodavstvo Ukrainy". "About the Notary Public": Law of Ukraine dated September 2. 1993 No. 3425-XII.

DOI (Article): https://doi.org/1.36486/np.2019.2.12

(c) Drozd Valentyna, 2019 
Database "Legislation of Ukraine". The Verkhovna Rada of Ukraine: [website]. URL: http://zakon5. rada.gov.ua/laws/show/3425-12 (date of application: 22.03.2019) [in Ukrainian].

9.Barannik R. V., Nazarenko P. H. (2011) Osoblyvosti okhorony informatsii, shcho stanovyt taшemn ytsшu u kryminalnomu sudochynstvi. "Features of protection of the information which is a secret in criminal proceedings". Lawyer. 2011. No. 4(127). 15-18 pp. [in Ukrainian].

10. Kurman O.V. (2016) Vidomosti, shcho stanovliat informatsiiu z obmezhenym dostupom yak predmet zlochynnoho posyahannia. "Information that constitutes restricted information as the subject of a criminal attack". Law and Society. No. 5. 174-178 pp. [in Ukrainian].

11. Marochkin O.I. (2016) Normy mizhnarodnoho prava ta rishennya Yevropeyskoho sudu z prav liudyny pro dostup do taiemnytsi slidstva. Pravove zabezpechennia operatyvno-sluzhbovoyi diialnosti: aktualni problemy ta shlyakhy yikh vyrishennia. "The rules of international law and the decision of the European Court of Human Rights on access to secrecy of the investigation. Legal support of operative-service activity: actual problems and ways of their solution": materials of a constantly acting science-practice. seminar, Kharkiv, May 27. 2016 / [editorial: S.O.Grinenko (ed.), Etc.]. Kharkiv, 2016. Vol. 7. 294-297 pp. [in Ukrainian].

12. Polonova H.I. (2017) Mistse tayemnytsi dosudovoho rozsliduvannia sered inshykh tayemnyts, okhoroniuvanykh zakonom pro kryminalnu vidpovidalnist. "The place of the secret of the pre-trial investigation is among other secrets protected by the law on criminal liability". Legal scientific electronic journal. No. 2. 138-141 pp. URL: http://lsej.org.ua j_2_2017.pdf (date of application: 22.03.2019) [in Ukrainian].

13. Osaulenko O.A. (2015) Kryminalni protsesualni harantiyi nerozholoshennia vidomostey dosudovoho rozsliduvannia. "Criminal procedural safeguards for non-disclosure of pre-trial investigation information”. Legal Science. No. 7. 185-193 pp. [in Ukrainian].

14. Kutazova I. V. (2011) Mekhanizm ugolovno-protsessualnogo obespecheniia nedopustimosti razglasheniia dannykh ugolovnogo sudoproizvodstva. "The Mechanism of Criminal Procedure to Ensure Inadmissibility of Disclosing Data of Criminal Justice": dis. Cand. Jurid. Sciences: 12.00.09. Tyumen. 24 p. [in Russian].

15. Lyash A. O. (2013) Nedopustymist roz-holoshennia vidomostey dosudovoho rozsliduvannia. "Inadmissibility of disclosure of information of pre-trial investigation". Journal of the National University of Ostroh Academy. No. 1(7). 1-14 pp. [in Ukrainian].

16. Pavlozskyi V. V. (2014) Teoretychni ta praktychni problemy zabezpechennia nedopustymosti roz-holoshennia vidomostey dosudovoho rozsliduvannia. "Theoretical and practical problems of ensuring the inadmissibility of disclosure of information of pre-trial investigation". Scientific Bulletin of the International Humanities University. Series: Jurisprudence. № 12. Vol. 2. 164-166 pp. [in Ukrainian].

17. Hryza O. V. (2016) Problemni pytannia zberezhennia tayemnytsi dosudovoho rozsliduvannia: suchasnyi stan ta perspektyvy. "Problematic issues of secrecy of pre-trial investigation: current state and prospects". Scientific Bulletin of Public and Private Law. Iss. 6. Vol. 2. 153-158 pp. [in Ukrainian].

UDC 343.98(477)

Drozd Valentyna,

Doctor of Juridical Sciences, Associate Professor,

Senior Research Associate, Leading Researcher,

State Research Institute MIA Ukraine, Kyiv, Ukraine, ORCID ID 0000-0002-7687-7138

\section{INADMISSIBILITY OF DISCLOSING INFORMATION OF PRE-TRIAL INVESTIGATION AS A PRECONDITION FOR ACHIEVING CRIMINAL PROCEEDINGS OBJECTIVES}

The article reveals the actual issues of regulation of non-disclosing information of pre-trial investigation as one of the preconditions for effective accomplishment of

DOI (Article): https://doi.org/1.36486/np.2019.2.12

(C) Drozd Valentyna, 2019 Issue 2(44) 2019 http://naukaipravoohorona.com/ 
criminal proceedings objectives. The author argues that the current CPC of Ukraine provides for a special procedure for disclosing information of a pre-trial investigation, as well as contains blanket sanctions in case of violation of requirements established. The focus is on the confidentiality of the pre-trial investigation information, therefore access to them is limited in order to prevent causing harm to the participants in criminal proceedings.

The analysis of the doctrinal study on problem issues of non-disclosing information of pre-trial investigation enables to allocate two main areas of the scientific research: 1) the study of the features of criminal procedure regulation of non-disclosing information of pre-trial investigation; 2) the study of organizational aspects of the procedural activities of the prosecution and law enforcement bodies in general.

Taking into account the research conducted, the relevant amendments and additions to the current legislation are proposed. First, paragraph 1 of Article 3 of the CPC of Ukraine should be supplemented with paragraph 24-1 as follows: "24-1) confidentiality of pre-trial investigation is a kind of confidential information that includes information on the activities of the pre-trial investigation body, the prosecutor's office, operational units in criminal proceedings, as well as the results of procedural actions, the application of measures to ensure criminal proceedings, the disclosure of which may affect adversely comprehensiveness, completeness and impartiality of the investigation". Second, in the title and content of Article 387 of the CC of Ukraine, the word "data" should be replaced with the word "information." Third, Article 222 of the CPC of Ukraine should be supplemented with the new paragraph 3 as follows: "3. Disclosure of information with restricted access is carried out in accordance with the procedure provided by the legislation concerning its use and access to it by other persons."

Keywords: criminal proceedings, confidentiality of pre-trial investigation, nondisclosure of information of pre-trial investigation, information with restricted access.

Отримано 07.06.2019

DOI (Article): https://doi.org/1.36486/np.2019.2.12

(c) Drozd Valentyna, 2019 


\section{Заросило Володимир Олексійович,} доктор юридичних наук, професор, завідувач кафедри управління безпекою, правоохоронної та антикорупційної діяльності

Навчально-наукового інституту права ім. Володимира Великого Міжрегіональної академії управління персоналом, м. Київ, Україна ORCID ID 0000-0001-6935-5449

\section{ОРГАНІЗОВАНА ЗЛОЧИННІСТЬ У СУЧАСНОМУ СВІТІ ТА В УКРАЇНІ: ФОРМИ, ВИДИ ТА ЗМІНИ}

У статті зроблено спробу узагальнити види організованої злочинності як $у$ світі, так $і$ в Украӥні для того, щоб розробляти певні заходи протидї.

Особлива увага приділена новим видам злочинів, таким як злочини у спортивній сфері, у сфері екологї та охорони природного середовища та у політичній сфері. Визначено, що такі злочинів є новими для організованих злочинних угруповань, але вони систематично вчиняються.

Запропоновано окремі шляхи щодо організащї протидії організованій злочинності, серед яких головним є питання про створення спеціальних підрозділів щодо протидії організованим злочинним групам.

Ключові слова: організована злочинність, трансначіональні злочинні корпорачї̈, кіберзлочини, злочинні угруповання, протидія організованій злочинності.

Питання організованої злочинності неодноразово обговорювалося в наукових колах. Слід зазначити, що термін “організована злочинність” уведений до наукових джерел порівняно недавно. Окремі дослідники вважають, що організована злочинність з'явилася у кінці XX століття. Проте, мабуть, можна говорити про більш ранні форми організованої злочинності. Вони з'явились ще у 18 ст., але зазначений термін для таких дій не застосовується. У цілому виникнення організованої злочинності зовсім новий та якісно відмінний від попередніх етапів розвитку злочинності.

Звичайні, “неорганізовані” злочинці в основному є маргінальними особами, які не знайшли місця в суспільстві, а діяльність організованих злочинних груп - це вже бізнес, іноді досить нелегко відрізнити бізнес від організованої злочинної діяльності.

Форми організованої злочинності змінювалися відповідно до розвитку суспільства та технічного прогресу. Сьогодні виокремлюються як форми, які існували ще в позаминулому столітті, зокрема рекет, работоргівля тощо, так і новітні: використання підроблених платіжних карток, зняття інформації з електронних носів з метою шантажу та викрадення коштів.

Таким чином, метою нашої статті є спроба узагальнити форми та види сучасної організованої злочинності, щоб на основі аналізу розробити методи протидії самій організованій злочинності.

DOI (Article): https://doi.org/10.36486/np.2019.2.13

(c) Zarosylo Volodymyr, 2019 
Організована злочинність виникла не одразу. Поступово відбувався процес інтеграції різних видів злочинної діяльності, яка стала організованою протиправною діяльністю. Ця кримінальна діяльність складається з різнорівневих стійких зв'язків, що є підгрунтям для утворення специфічних структур, метою яких є злочинна діяльність. Так, І.М. Даньшин визначає організовану злочинність як “згуртування кримінального середовища в масштабі певного регіону, окремої галузі господарства (іiї виробничих об'єднань) або в певних сферах управління шляхом утворення стійких, згуртованих, ієрархічно побудованих злочинних угруповань (спільнот), зорієнтованих на тривалу злочинну діяльність із метою здобування постійних значних доходів" [1]. У цілому питаннями організованої злочинності найбільше цікавилися представники кримінологічних наук $[2,3,4,5]$, також вона вивчалася представниками інших напрямів наукових досліджень. Наприклад, В.Д. Гвоздецький розглядав організовану злочинність як "найбільш стійке, чітко структуроване антисоціальне явище, що найповніше вживається у державно-владні структурі для власних корисливих цілей” [6]. Слід зазначити, що форми організованої злочинності значно змінилися з того часу, як вона була визначена. Тим більше, як вже зазначалося, досить часто організована злочинність не відрізняється від бізнесу та різних бізнесових операцій.

Питання про визначення видів злочинів, які вчиняються організованими злочинними угрупованнями, досить часто розглядалося як у практичних аналізах вітчизняних, так і зарубіжних дослідників.

На сучасному етапі розвитку організованої злочинності виокремлюються різні види злочинів, але на першому місці стоять злочини, пов’язані з фінансами. Серед них виділяють такі, як:

- підробка саме грошових купюр, але вона не робиться у великих розмірах, або фальшивомонетництво. В Україні досить детально цим питанням займалося чимало дослідників, серед яких слід виокремити О.О. Дудорова [8];

- махінації з платіжними картками, спрямовані на отримання грошей шляхом зняття інформації з каналів зв’язку та використання підроблених кодів;

- махінації з особистими даними, використання особистої інформації з метою рекету та вимагання грошей за нерозголошення отриманої інформації.

Спорідненими злочинами, пов'язаними з фінансами, є злочини у сфері кіберпростору. Вони також пов'язані з вимаганням грошей, використанням приватної інформації, викраденням особистих даних та їх використання з метою завдання шкоди особі, яка допустила втрату таких даних. Крім того, поширені операції 3 картками та іншими платіжними документами, які використовуються в Інтернеті.

Водночас є й інші види злочинів, що вчиняються злочинними організаціями. Це насамперед хакерські атаки на різні установи або громадян з метою як вимагання грошей, так і нанесення шкоди як партнерам по бізнесу, так і державним організаціям. Достатньо згадати комп'ютерний вірус “Петя”, який зашкодив не тільки приватним громадянам, а й державним установам. В основі діяльності зазначеного вірусу було звичайне вимагання грошей. При цьому вірус поширювався досить швидко, і встановити, хто його запустив, було неможливо [7].

Досить поширеними є також кіберзлочини, пов’язані з експлуатацією дітей, дитячою порнографією, особистими даними, сексуальною експлуатацією, виго-

DOI (Article): https://doi.org/10.36486/np.2019.2.13

(c) Zarosylo Volodymyr, 2019 Issue 2(44) 2019 http://naukaipravoohorona.com/ 
товленням і поширенням рейкової інформації, створенням негативного іміджу тощо. При цьому такі кіберзлочини вчиняються не тільки за замовленням окремих осіб, а навіть політичних партій.

Так, у деяких дослідженнях кіберзлочини, пов’язані з експлуатацією дітей, порнографією, работоргівлею, визначаються окремим терміном “злочини у сфері людських ресурсів" [9].

Третім “традиційним” видом злочинів, які вчиняються організованими злочинними угрупованнями, є злочини, пов’язані з розповсюдженням наркотичних засобів. Звичайно, головними напрямами у цій сфері є переправляння наркотичних засобів, які виробляються в країнах Південної, Центральної Азії та Латинської Америки до Сполучених Штатів Америки і Свропи, де є найбільший попит на такі речовини.

Проте зазначені види злочинів сьогодні стали більш організованими, при їх учиненні використовуються новітні технології.

Новими видами злочинів, які вчиняються організованими злочинними угрупованнями, на сьогодні є:

- виробництво синтетичних наркотиків та їх розповсюдження, адже вони дешевші від тих наркотиків, які вироблялися раніше, їх легше переправляти через кордони;

- розповсюдження наркотичних засобів із використанням всесвітньої мережі Інтернет, де не завжди можна встановити, звідки направлені згадані наркотичні засоби;

- культивування та вирощування наркотиковмісних рослин та їх розповсюдження. До речі, такий вид злочинів виявлено і в Україні.

Новим видом злочинності, яка вчиняється організованими злочинними угрупованнями, за висновками фахівців, є також злочини, пов'язані з забрудненням навколишнього середовища. Такі види злочинів сприяють забрудненню земель, води та повітря і відповідно впливають на здоров’я людини.

До таких злочинів відносяться:

- неправильне збирання, зберігання та утилізація токсичних особливо небезпечних речовин, які є відходами виробництва;

- неправильне транспортування небезпечних речовин, яке призводить до аварій та катастроф, унаслідок яких виникає забруднення навколишнього середовища та відповідно вплив на життя і здоров’я людей;

- неправильна технологічна переробка токсичних та отруйних речовин, які можуть викликати хвороби та наносити шкоду навколишньому середовищу;

- знищення окремих видів тварин та птахів, що впливає на зміни в екосистемі, а тварини та їхні частини використовуються для виготовлення різних речей та одягу.

Небезпечними злочинами, які вчиняються організованими злочинними угрупованнями, є також різні види контрабанди. На сьогодні використовуються такі види контрабанди, як: контрабанда паливно-мастильних матеріалів, медичних препаратів, окремих видів продуктів харчування. Крім того, поширюється контрабанда високотехнологічних виробів, транспортних засобів та іншого майна. При цьому зазначені злочини завжди включають й інші види злочинів, зокрема викрадення, грабіж, розбій та шахрайство.

DOI (Article): https://doi.org/10.36486/np.2019.2.13

(C) Zarosylo Volodymyr, 2019 Issue 2(44) 2019 http://naukaipravoohorona.com/ 
Ці злочини здебільшого вчиняються окремими злочинними угрупованнями, що спеціалізуються на викраденні транспортних засобів, творів мистецтва, ювелірних виробів, електронних приладів та іншого майна. Після викрадення зазначені вироби з порушенням митного законодавства переправляються до інших країн.

Організованими злочинними угрупованнями на сучасному етапі розвитку організованої злочинності активно використовуються також людські ресурси.

До злочинів, пов'язаних із людськими ресурсами, відносяться такі:

- сприяння нелегальній міграції, яка здійснюється з метою проживання на території інших країн чи отримання роботи;

- нелегальне переміщення осіб з метою сексуальної експлуатації;

- нелегальне переміщення осіб з метою отримання органів людей для подальшого продажу і проведення операцій по заміні органів;

- сприяння нелегальному переміщенню дітей з метою всиновлення або різних видів експлуатації, рабства, сексуальної експлуатації тощо.

Слід зазначити, що порівняно новим видом злочинів, що вчиняються організованими злочинними угрупованнями, є злочини у спортивній сфері. Такі злочини стосуються проведення договірних матчів та отримання прибутку від відповідних ставок на виграші. Застосування різних спеціальних засобів для отримання тих чи інших результатів спортивних змагань, що також є новим в організованій злочинності. Це стосується використання медичних препаратів та інших речовин. В основному більшість таких злочинів вчиняється під час проведення футбольних матчів, але вони можуть вчинятися й в інших видах спорту.

Традиційною сферою діяльності організованих злочинних угруповань $є$ також торгівля зброєю. Вона здійснюється як шляхом контрабанди зброї, так і з використанням всесвітньої мережі Інтернет. При цьому останній вид злочинів є найбільш латентним.

Торгівля зброєю є особливо небезпечним злочином на території України нині, коли країна знаходиться у стані збройного конфлікту.

Новим видом злочинів, які вчиняються організованими злочинними угрупованнями, $є$ такий, як створення спеціальних озброєних формувань та терористичних організацій, які використовуються з метою дестабілізації ситуації в тих чи інших регіонах, та сприяння вчиненню інших злочинів, таких як захоплення території, корисних копалин тощо.

Порівняно новими видами злочинів, які вчиняються організованими злочинними угрупованнями, є злочини у сфері інтелектуальної власності, що включають у себе незаконний продаж підроблених товарів, особливо високотехнологічних, виробництво певних видів товарів і нелегальне переправлення їх до інших країн, а також використання торгівельних марок та брендів відомих фірм.

Підсумовуючи, необхідно зазначити, що організована злочинність практично відтворює всі шляхи розвитку суспільства. Її керівники усвідомлюють, що звичайним легальним шляхом можна отримувати певні прибутки, але нелегальні та незаконні шляхи дають прибуток у кілька разів більший.

Крім того, у світі спостерігається розподіл держав на успішні й ті, що знаходяться на межі бідності. Цим користуються керівники організованої злочинності. Використання людських ресурсів на сьогодні є також досить важливим джерелом прибутку для злочинних угруповань.

DOI (Article): https://doi.org/10.36486/np.2019.2.13

(C) Zarosylo Volodymyr, 2019 
Міжнародні організації та правоохоронні органи всіх держав створюють відповідні структури, які мають здійснювати протидію організованим злочинним угрупованням. В Україні, на жаль, після ліквідації УБОЗу до сьогодні не створено відповідної структури, яка б займалася питаннями організації злочинності у системі Національної поліції. $Є$ відповідні структури в системі Служби безпеки України, але вони мають специфічні завдання і тяжіють до протидії організованим злочинним угрупованням, які створюють загрози для державної безпеки.

Не здійснюється в Україні і систематичний аналіз виникнення та розвитку організованих злочинних угруповань, що в цілому негативно впливає на стан протидії злочинності.

\section{СПИСОК ВИКОРИСТАНИХ ДЖЕРЕЛ}

1. Даньшин І.М., Голіна В.В., Валуйська М.Ю. та ін. Кримінологія: Загальна та Особлива частини: [підр.] / за заг. ред. В.В. Голіни: 2-ге вид. перероб. і доп. Х.: Право, 2009. 288 с.

2. Міняйло Н.Є. Межі застосування поняття "організована злочинність" в Україні. Наук. вісник Міжн. гум. ун-ту. 2015. № 14. Серія “Юридична”. Т. 2. С. 75-78.

3. Куи В.М., Лизогуб Б.В. Теоретичне визначення поняття організованої злочинності. Наукові записки ХЕПУ. № 1. 2004. С. 66-78.

4. Мельничук T.B. Організовані форми злочинної діяльності у зовнішньоекономічній сфері: кримінологічне дослідження: автореф. дис. ... канд. юрид. наук: 12.00.08. Одеса, 2009. 20 с.

5. Федосов E.В. Узагальнена класифікація організованих злочинних угруповань. Боротьба з організованою злочинністю і корупцією (теорія і практика). 2013. № 1. С. 93-102.

6. Гвоздецький В.Д. Організована злочинність як об'єкт соціально-філософського аналізу: автореф. дис. ... канд. філос. наук: 09.00.03. К., 1997. 30 с.

7. Кібератака вірусу Пєтя: що відомо. URL: https://www.dw.com/uk/\%D0\%BA\%D1\%96\% D0\%B1\%D0\%B5\%D1\%80\%D0\%B0\%D1\%82\%D0\%B0\%D0\%BA\%D0\%B0\%D0\%B2\%D1\%96\% D1\%80\%D1\%83\%D1\%81\%D1\%83-petya-\%D1\%89\%D0\%BE\%D0\%B2\%D1\%96\% D0\%B4\%D0\%BE\% D0\%BC\%D0\%BE/a-39452258 (дата звернення: 15.03.2019).

8. Дудоров О.О. Злочини у сфері господарської діяльності: кримінально-правова характеристика: монографія. К.: Юридична практика, 2003.

9. Human Resources in Criminal Justice. Florida Department of Law Enforcement. James T. Moore, Commissioner Octobe 1994.

\section{REFERENCES}

1. Danshyn I.M., Holina V.V., Valuiska M.Yu. ta in. (2009) Kryminolohiia: Zahalna ta Osoblyva chastyny. "Criminology: General and Special sections": [ed.] / By head. ed. V.V. Branches: 2nd view. recycling. and ext. X.: Pravo. 288 p. [in Ukrainian].

2. Minyaylo N. Ye. (2015). Mezhi zastosuvannia poniattia "orhanizovana zlochynnist" v Ukraini. "Limits of application of the concept of "organized crime" in Ukraine". Science newsletter Intern. rubber. un-tu. № 14. Series "Legal”. Vol. 2, 75-78 pp. [in Ukrainian].

3. Kuts V.M., Lyzohub B.V. (2004). Teoretychne vyznachennia poniattia orhanizovanoi zlochynnosti. "Theoretical definition of the concept of organized crime". HEPU Scientific Notes. No. 1. 66-78 pp. [in Ukrainian].

4. Melnychuk T.V. (2009). Orhanizovani formy zlochynnoi diialnosti u zovnishnoekonomichnyi sferi: kryminolohichne doslidzhennia. "Organized forms of criminal activity in the foreign economic sphere: criminological research": author. diss. Ph.D.: 12.00.08. Odessa. 20 p. [in Ukrainian].

5. Fedosov E.V. (2013). Uzahalnena klasyfikatsiia orhanizovanykh zlochynnykh uhrupovan. Borotba z orhanizovanoiu zlochynnistiu i koruptsiieiu (teoriia i praktyka). "Generalized classification of organized criminal groups. Combating Organized Crime and Corruption (Theory and Practice)". № 1. 93-102 pp. [in Ukrainian].

6. Hvozdetskyi V.D. (1997). Orhanizovana zlochynnist yak obiekt sotsialno-filosofskoho analizu. "Organized crime as an object of social and philosophical analysis": abstract. diss. Ph. D.: 09.00.03. K. 30 p. [in Ukrainian].

DOI (Article): https://doi.org/10.36486/np.2019.2.13

(c) Zarosylo Volodymyr, 2019 
7. Kiberataka virusu Pietia: shcho vidomo. "Cyber-attack Petya virus: what is known". URL: https://www.dw.com/en/\%D0\%BA\%D1\%96\%D0\%B1\%D0\%B5\%D1\%80\%D0\%B0\%D1\%82 \% D0\% B0\% D0\% BA\% D0\% B0\% D0\% B2\% D1\% 96\% D1\% 80\% D1\% 83\% D1\% 81\% D1\% 83-petya-\% D1\% 89\% D0\% BE\% D0\% B2\% D1\% 96\% D0\% B4\% D0\% BE\% D0\% BC\% D0\% BE / a-39452258 (date of application: 15.03.2019) [in Ukrainian].

8. Dudorov O.O. (2003) Zlochyny u sferi hospodarskoi diialnosti: kryminalno-pravova kharakterystyka. "Crimes in the field of economic activity: criminal characteristics": monograph. K.: Legal Practice [in Ukrainian].

9. Human Resources in Criminal Justice. Florida Department of Law Enforcement. James T. Moore, Commissioner October 1994 [in English].

UDC 343.974(100:477)

Zarosylo Volodymyr, Doctor of Juridical Sciences, Professor, Head of the Department, Volodymyr the Great Educational and Scientific Institute of Law Interregional Academy of Personnel Management, Kyiv, Ukraine,

ORCID ID: 0000-0001-6935-5449

\section{ORGANIZED CRIME IN THE MODERN WORLD AND UKRAINE: FORMS, TYPES AND CHANGES}

The current state of organized crime is of concern not only to ordinary citizens, but also to the leadership of States. Transnational criminal corporations are harming not only individual states, but society as a whole. Unfortunately, as of today, there are no relevant police forces in Ukraine that would be aimed at organizing the counteraction against an organized criminal group.In addition, the analysis of the system of organized crime of its types and types is not always carried out.

The article attempts to generalize the types of organized crime in the world and in Ukraine in order to make certain measures of counteraction. It should be noted that organized crime groups commit many types of crimes, but they are not structured. In order to better understand the types of crimes committed by organized criminal groups, a certain list of such crimes is proposed.

They are divided into several areas: economic, cybercrime, human rights crimes, intellectual property and high-tech crime, sports crime, environmental crime, and crime in the political sphere.

Of course, the methodology for the division of crimes can be changed, but all types of crimes committed by organized criminal groups are highlighted in the article.

Particular attention is paid to new types of crimes such as crimes in the sports sector, in the field of ecology and environmental protection and in the political sphere. It is determined that such crimes are new to organized criminal groups, but they are systematically committed.

Some ways of organizing counteraction to organized crime are offered, among which the main issue is the creation of special units for counteraction to organized criminal groups.

Keywords: organized crime, transnational criminal corporations, cybercrime, criminal groups, countering organized crime.

Отримано 05.06.2019

DOI (Article): https://doi.org/10.36486/np.2019.2.13

(C) Zarosylo Volodymyr, 2019

Issue 2(4.4) 2019

http://naukaipravoohorona.com/ 
УДК: 340.113

Користін Олександр Євгенійович, доктор юридичних наук, професор, заступник директора ДНДІ МВС України,

м. Київ, Україна

ORCID ID 0000-0001-9056-5475;

Собко Ганна Миколаївна,

кандидат юридичних наук, доцент, професор кафедри кримінального права та кримінології Одеського державного університету внутрішніх справ, м. Одеса, Україна

ORCID ID 0000-0002-5938-3400

\section{МЕТОДОЛОГІЧНІ ЗАСАДИ ОСМИСЛЕННЯ ФЕНОМЕНУ “НАСИЛЬСТВО” У КРИМІНАЛЬНОМУ ПРАВІ}

У статті досліджуються погляди представників різних наукових шкіл щодо визначення феномену “насильство”, зокрема, з акцентом на особливостях його співвідношення з поняттям “примус". Зазначено, що як примус, так $і$ насильство буває безпосереднім, індивідуалізованим і опосередкованим, закодованим в інститутах і механізмах суспільства, прихованим і відкритим, фізичним і психологічним.

Окреслено та виділено загальні трактування сутності феномену насильства та акцентовано увагу на притаманних насильству ознаках. Крім того, зазначено, що отримані в иій статті результати створюють методологічне підгрунтя для подальшого удосконалення системи знань щодо поняття насильства у кримінальному праві.

Ключові слова: насильство, примус, категорія, поняття, феномен насильства, філософсько-правові концепцї, методологічні аспекти.

Сьогодні відбуваються соціальні зміни, які стали не просто нормою, а умовою існування суспільства. У цьому аспекті насильство є результатом боротьби нового зі старим, воно стає не просто неминучим, а й певним інструментом для досягнення мети та успіху. Водночас насильство часто змішують з поняттям примусу, зокрема, знаходиться виправдання насильству, і воно вже перетворюється на примус, особливо на легітимний примус. Таким чином, навіть у демократичних державах можна виправдати і війни, і навіть повсякденне насильство у сім'ї, насильство відносно слабких тощо.

Метою цієї статті є дослідження методологічних засад щодо осмислення феномену “насильство”, зокрема, з акцентом на особливостях його співвідношення 3 поняттям “примус".

Як правило, насильство означає свідоме, навмисне застосування різних форм примусу відносно особистостей, груп людей, націй, класів та інших соціальних груп, тобто сковування свободи. Як примус, так і насильство буває безпосереднім, індивідуалізованим і опосередкованим, закодованим в інститутах і механізмах

DOI (Article): https: //doi.org/10.36486/np.2019.2.14

(c) Korystin Oleksandr, Sobko Hanna, 2019 Issue 2(4.4) 2019

http://naukaipravoohorona.com/ 
суспільства, прихованим і відкритим, фізичним і психологічним. Будь-яке насильство є примусом, але не будь-який примус є насильством.

Примус може бути необхідним. Такий примус спрямовано на збереження порядку, забезпечення безпеки громадян (прикладом може бути перешкода самогубцю покінчити з життям, вживати алкоголь, наркотики, гвалтувати, красти тощо). Завдяки примусу мають дотримуватися загальнолюдські норми і правила. Примус також може застосовуватися з метою зробити добро. Але нерідко добрі наміри для інших і для більшості повертаються злом. Примус під виглядом благодіяння може робити явне зло. Він може бути власне насильством - результатом свідомого, навмисного довільного застосування сили, що перешкоджає особистості, верствам, групам розвивати свої творчі здібності, свою індивідуальність, незалежно від того, які результати, яке значення матиме для тих, на кого впливають.

Примус завжди супроводжується обмеженням волі, але свобода ніколи не може бути безмежною, вона сковується нормами моралі, нормами права, виробничою, сімейною необхідністю. Усвідомивши ті чи інші форми або правила, закони, людина може в межах цих правил здійснювати свою діяльність, тому примус у різних формах необхідний. Але наскільки він необхідний, чи можливо уникнути насильства?

Цивілізований світ має протистояти та протидіяти насильству, а не змагатися у насильстві. 3 метою успішного протистояння насильству виникає потреба у докладному аналізі, у безпосередньому вивченні цього феномену та усвідомленні його змісту для подальшого вироблення та удосконалення правових заходів протидії.

Зазначена проблематика представлена широкою палітрою різноманітних досліджень. Це питання в тому чи іншому аспекті досліджувалося низкою вчених, але означена проблема зумовлює потребу у з'ясуванні змісту цієї категорії, яка розглядається в різних аспектах: історичному, соціологічному, психологічному, юридичному, антропологічному, біологічному, політичному та відноситься до, так званих, загальнонаукових понять, які відіграють інтегративну роль, поєднуючи навколо себе результати досліджень різноманітних наук.

Розв’язання зазначеного має важливе значення для наукового дослідження у будь-якій галузі правових знань, оскільки визначає вихідні засади такого небезпечного соціального явища. Незважаючи на численність наукових робіт у напрямі осмислення цього поняття, ми акцентуємо увагу на деяких питаннях осмислення поняття насильства, зокрема з погляду філософії. Адже філософія виробляє такі загальнотеоретичні принципи пізнання, як об’єктивність, всебічність, доповнення, принцип активності суб'єкта і деякі інші, які може і повинна використовувати теорія права. Філософія не займається створенням спеціальних правових категорій. Це справа теорії права. Але оскільки право входить у систему соціальних відносин та інститутів, безпосередньо пов'язане з буттям людини, то теорія права користується понятійним апаратом, що розробляється філософією і має універсальне значення. Зокрема, одним із таких понять, яким користується юридична наука, є поняття "насильство".

У цьому контексті справедливо наголошує А.О. Йосипів, що “насильство” слід відносити до, так званих, загальнонаукових понять, які відіграють інтегративну

DOI (Article): https: //doi.org/10.36486/np.2019.2.14

(C) Korystin Oleksandr, Sobko Hanna, 2019

Issue 2(4.4) 2019

http://naukaipravoohorona.com/ 
роль, поєднуючи навколо себе (синтезуючи, акумулюючи в собі) результати досліджень різноманітними науками різних видів агресії або насильства [1, с. 62].

Перша тематизація насильства у філософському дискурсі належить Гераклітові, у його знаменитому 29-му фрагменті, в якому війну він називав батьком усіх, царем усіх: одних вона повідомляє богами, інших - людьми, одних творить рабами, інших - вільними [2, с. 202].

Аристотель розглядав силу як свого роду категорію категорій, фундаментальну категорію всього сущого. Зрозуміло, сила не тотожна насильству; про останнє мова йде тільки тоді, коли при зіткненні суверенних сил має місце подолання однієї сили іншою. Насильство розуміється Арістотелем як природна необхідність і фізична закономірність: "Насильство та примус, а таким є те, що заважає й перешкоджає в чому-небудь, всупереч бажанню й власному рішенню. Справді, насильство називається необхідністю; тому воно й тяжке” [3, с. 151].

Якщо вільні античні філософи експлікували переважно “силовий” бік насильства, то представники середньовічної філософії виявили інший, “авторитетний” аспект насильства, пов’язаний з компетентністю, здатністю розпоряджатися, умінням наполягти на своєму. У силу того, що схоластична філософія була можлива тільки на правах служниці теології й світоглядна позиція філософа неминуче виявлялася визначена християнськими догматами, схоластам дісталося завдання теодицеї, у межах якої й проходила у часи Середньовіччя розробка проблематики насильства. Августин і Фома Аквінський стали тими, хто дав проблемі зла в створеному Богом світі задовільне рішення; перший - на базі неоплатонічної філософської традиції, другий - на базі арістотельської [4, с. 107-120; 5, с. 66-73].

Подібно до того, як у політичній традиції, мається на увазі, що в державі здійснюється перехід від насильства до влади й права через монополізацію насильства, у традиції релігійно-християнській будь-яке вихідне від Бога насильство розглядається як конструктивне й легітимне. Метафізична прірва між “градом земним” і “градом Божим” не порушує структурно-функціональної єдності насильства. Новоєвропейська зміна філософської парадигми відбилася й на проблематиці насильства, розгляд якої було перенесено з області онтології й метафізики в сферу політичної філософії у працях Т. Гоббса, Д. Локка, Ж.-Ж. Руссо.

Т. Гоббс у трактаті “Левіафан” розробив теорію суспільного договору. На думку філософа, без суспільного договору люди не здатні до мирного співіснування у силу природної ворожнечі один до одного, “боротьби всіх проти всіх” [6]. Монополізуючи насильство, державна влада робить всі інші форми насильства незаконними й тим самим рятує суспільство від небезпеки зникнення в хаосі неконтрольованого тотального насильства.

Д. Локк у “Двох трактатах про правління” доповнив цю теорію ідеєю існування природних прав людини, до яких він відносив право на життя, волю, власність. Замах на природні права людини є насильством, нейтралізація якого є необхідною функцією державної влади, передусім - її виконавчої галузі [7]. Ж.-Ж. Руссо ввійшов в історію політичної думки як автор знаменитого “Суспільного договору", у якому подавалося теоретичне обгрунтування цивільного суспільства, заснованого на волі й безумовній рівності юридичних прав громадян [8]. Новий стиль філософського мислення привів до вироблення розвиненого юридичного мислення

DOI (Article): https: //doi.org/10.36486/np.2019.2.14

(c) Korystin Oleksandr, Sobko Hanna, 2019 Issue 2(44) 2019 http://naukaipravoohorona.com/ 
щодо насильства, основні постулати якого й понині залишаються непорушними підставами конституційного права будь-якого цивілізованого суспільства. Новоєвропейські політико-філософські розробки проблематики насильства одержали свій розвиток у працях представників німецької класичної філософії.

У трактаті “До вічного миру” І. Кантом уперше висловлено здогад про об’єктивну закономірність, що веде до встановлення вічного миру, про неминучість створення на мирних засадах союзу народів. Тут відбувається те ж, що й 3 окремими людьми, що поєднуються в державу, щоб перешкодити взаємному винищуванню. Держави змушені будуть “вступити в союз народів, де кожна, навіть найменша держава могла б очікувати своєї безпеки й прав не від своїх власних сил, а винятково від такого великого союзу народів” [9, с. 285].

Інший представник німецької класичної філософії І. Гердер вважає, що угода, укладена в умовах ворожих відносин між державами, не може бути надійною гарантією миру. Для досягнення вічного миру необхідно моральне перевиховання людей. Гердер висуває низку принципів, за допомогою яких можна виховати людей у дусі справедливості й людяності; зокрема відраза до війни, менше шанування військової слави [10, с. 360].

Дисгармонією є думка Гегеля, що війна здійснює історичний вирок цілим народам, які не пов’язані з абсолютним духом. За Гегелем, війна - двигун історичного прогресу, "війна зберігає здорову моральність народів у їх індиференції стосовно визначеностей, до їхньої звичності й укорінення...” [11, с. 289].

Послідовники Гегеля неоднозначно оцінювали роль насильства у світовій історії. Є. Дюрінг намагався обгрунтувати положення, що “первинне все-таки варто шукати в безпосередньому політичному насильстві, а не в непрямій економічній силі”. У роботі “Анти-Дюрінг” Ф. Енгельс рішуче відкидає цю абсолютизацію насильства, наголошуючи, що приватна власність на засоби виробництва виникли “в інтересах підвищення виробництва й розвитку обміну, - отже, згідно 3 економічними причинами. Насильство не відіграє при цьому ніякої ролі” [12, c. 166].

На наше переконання, у кінці XIX століття заслуговують на увагу погляди німецького соціолога М. Вебера, який починає розглядати насильство через призму легітимності і в його зв’язку з державою: “Держава, так само як і політичні союзи, історично їй попередні, є відношенням панування людей над людьми, що спирається на легітимне (тобто таке, що вважається легітимним) насильство як засіб” $[13$, с. 645$]$.

У західній філософській традиції ХХ століття створюються теоретичні роботи, присвячені проблематиці насильства, формується особливий дискурсивний простір, для якого характерне розрізнення категорій “насильство”, “сила”, “влада”. До основних робіт, які, на наше переконання, заслуговують на особливу увагу та детальне вивчення, можна віднести: "Роздуми про насильство” французького філософа та соціолога Ж. Сореля, в якій автор висуває поняття міфу про загальний страйк як колективне мобілізуюче уявлення, здатне стати основою революційних трансформацій; “До критики насильства” німецького філософа В. Беньяміна, роботи якого лежать в основі сучасного розуміння модернізму, а самого вченого вважають одним із найвпливовіших філософів культури ХХ століття; “Про насильство”

DOI (Article): https: //doi.org/10.36486/np.2019.2.14

(C) Korystin Oleksandr, Sobko Hanna, 2019

Issue 2(4.4) 2019

http://naukaipravoohorona.com/ 
X. Арендт, в якій німецько-американський філософ, політичний теоретик та історик радикально переосмислює феномен насильства, що традиційно вважався якщо не основою влади, то одним з основних способів її здійснення, зокрема, якщо вважати владою легітимну форму панування, притаманну будь-якій групі узгоджено діючих людей, насильство виявляється іï повною протилежністю його застосування завжди є наслідком слабкості влади і продовжує її руйнувати.

Не можна не виділити роботи фахівців другої половини ХХ століття, що характеризуються дослідженням поняття насильства через спробу осмислення зв’язку жахів Другої світової війни (Голокосту) і основних принципів модерну. Так, необхідно згадати "Негативну діалектику" - одну з головних теоретичних робіт німецького філософа та соціолога Теодора Адорно, а також його спільні роботи з Максом Хоркхаймер “Діалектика освіти”; “Актуальність голокосту" 3. Баумана, "Homo Sacer. Що залишається після Освенцима: архів і свідок” Д. Агамбена. Особливу думку, що вплинула на інших мислителів, на проблематик'у насильства у його зв’язку з колоніалізмом, представив у своєму творі “Les damnes de la terre” Ф. Фанон. У дослідження проблеми зробив важливий вклад ще один представник франкфуртської школи - Г. Маркузе, який у своїй творчості торкається теми репресивності цивілізації, бунту, революційної теорії ("Ерос і цивілізація”, “До ситуації нових лівих"). Особливе місце в осмисленні ролі насильства в діяльності окремих соціальних інститутів займають роботи М. Фуко, такі як, наприклад, “Наглядати і карати” і “Безпека, територія, населення”.

Варто зазначити, що чимало вчених, зокрема психологів, психіатрів, психоаналітиків (наприклад, З. Фрейд, К. Лоренц, Б.Ф. Скіннер ), вивчали поведінку тварин, досліджували феномен насильства (або в цьому випадку - агресії) через зв’язок психіки людини, її біологічних властивостей з проявами агресії.

У другій половині XX століття радянські автори в цілому перебували в руслі загальноєвропейської філософської традиції осмислення проблеми насильства. Насамперед необхідно назвати сучасного дослідника В.В. Денисова, який написав у 1975 р. роботу “Соціологія насильства”, в якій зібрано унікальний історико-філософський матеріал по темі, проаналізовано майже всі існуючі на той момент концепції насильства. На особливу увагу заслуговують роботи А.А. Гусейнова ("Моральна демагогія як форма апології насильства”, "Мораль і насильство”, “Етика ненасильства” тощо), він не один десяток років працює в області етики ненасильства, вироблення можливих визначень поняття “насильство”. Питання насильства і ненасильства, війни і моралі всебічно розглядаються в творчості Р.Г. Апресяна (“Досвід ненасильства в XX столітті”, “Насильство і ненасильство: філософія, політика, етика”, “Моральні обмеження війни: проблеми та приклади”). Величезну теоретичну глибину мають твори Б.Г. Капустіна (зокрема “До поняття політичного насильства”), в яких можна знайти одну з небагатьох спроб створити концепцію насильства в межах того дискурсивного простору, який на Заході представляють Х. Арендт, Ж. Сорель, В. Беньямін.

Варто відзначити також дослідження з проблеми насильства, які проводять учені в суміжних із філософією соціально-гуманітарних сферах, серед них Я.І. Гилинський (“Соціальне насильство”), А.П. Назаретян (“Антропологія

DOI (Article): https: //doi.org/10.36486/np.2019.2.14

(c) Korystin Oleksandr, Sobko Hanna, 2019 
насильства і культура самоорганізації. Нариси з еволюційно-історичної психології”, “Еволюція ненасильства: історична ретроспектива”).

В останній чверті XX - початку XXI століть у Свропі починають складатися теорії, які вивчають насильство з позицій соціальної феноменології та соціального конструктивізму. Серед творів, що вплинули на це дослідження, можна назвати “Феномен насильства” Д. Річеса і “Насильство. Новий підхід” М. Віевіоркі.

Серед робіт останнього часу на особливу увагу заслуговує праця "Про насильство” словенського вченого С. Жижека, в якій розглядається питання про зв’язок соціальної системи, ідеології і насильницьких актів. Автор приховане насильство вважає таким собі “вічним двигуном”, джерелом різноманітних форм видимого насильства, зокрема він розглядає загрозу глобального тероризму, з одного боку, і “монополію на застосування фізичного насильства", яка характерна для сучасної держави, з іншого. Насильство - це не пряма характеристика певних дій, воно розподілено між діями і їх контекстом, між діяльністю і бездіяльністю. Проаналізовано правомірність вираження насильства через три його форми: об'єктивну, суб'єктивну і символічну. Зокрема, об'єктивне насильство, разом із насильством суб'єктивним і символічним, є відправним моментом, джерелом, причиною зла як такого. Славой Жижек акцентує увагу на тому, що потрібно навчитися усуватися від видимого “суб'єктивного” насильства, вчиненого будь-якою чітко розпізнаною силою. Таке відсторонення дозволяє розпізнати насильство, яке лежить в основі наших спроб боротьби з насильством, і сприяти толерантності. Метод універсальний і справно нищить будь-яку очевидність.

Окремої уваги заслуговує думка І. Ільїна про причини походження насильства. Це питання він розглядав, зважаючи на конкуренцію між особистостями, кожна з яких прагне “за найменшої витрати сил отримати найбільше задоволення, тобто працювати якомога менше, а отримувати за це щонайбільше” [14, с. 66.]. Така конкуренція полягала в зіткненні різних інтересів у спільній боротьбі за існування. Під інтересом науковець розуміє “ставлення тієї людини, що живе і бажає всього того, що їй необхідно або важливо”.

Коли здобуває перемогу людина з таким інтересом, I. Ільїн називає це конкуренцією, вона не стосується всіх доступних рівною мірою благ, яких вистачить усім: повітря у просторі, води в річках, світла в полі тощо. “Але боротьба виникає негайно, як тільки повітря (наприклад, у маленьких комірках), або води (наприклад, у пустелі або при псуванні водопроводу), або світла виявляється в обмеженій кількості. Все, що забезпечує або полегшує життя людини і чого в цей момент на всіх не вистачає - все це викликає конкуренцію і загострює боротьбу за існування до такої міри, що люди стають один одному ворогами” [15, с. 74.].

Так пояснює походження насильства I. Ільїн. Воно є однією з форм або одним із видів боротьби, в процесі якої застосовуються різні способи придушення волі конкурентів, зокрема шляхом насильства. Однак слід зазначити, що це твердження Ільїна про причини походження насильства мають або однобокий, або настільки осяжний характер, що поняттями “інтерес" і “конкуренція” охоплюються й інші причини застосування насильства, які можуть мати політичний, правовий, кримінальний і побутовий характер. Походження насильства він вбачав у “наявності душевної схильності людини до зла як результату його суб'єктивної

DOI (Article): https: //doi.org/10.36486/np.2019.2.14

(C) Korystin Oleksandr, Sobko Hanna, 2019

Issue 2(4.4) 2019

http://naukaipravoohorona.com/ 
оцінки, яку порівнював з “розгнузданістю” звіра, з тяжінням до розширення влади і повноти захоплення. Таким чином, зла воля людини пояснюється його внутрішніми мотивами. Тільки вони можуть викликати будь-які його рухи тіла, які можуть проявлятися, наприклад, у примушуванні та насильницьких діях" [15, c. 395.].

Дослідивши думки та позиції згаданих вище науковців, можна виділити кілька трактувань сутності феномену насильства.

По-перше, насильство як суспільний інститут. Форми насильства в сучасному світі - це нерівний розподіл добробуту, безробіття, попрання прав людини та релігійної свободи, расизм, сексизм, корупція, наркоманія, насильство в сім’ї і на вулиці, стреси, страх, тиск ЗМІ [16].

По-друге, насильство як прояв індивідуальної людської агресії, ірраціонального біологічного інстинкту, де насильство виступає як продукт людської природи (наприклад, роботи Гоббса, Ніцше, Фрейда), відбувається біологізація і психологізація насильства. Другий напрям поширився в другій половині XIX століття спочатку під назвою соціал-дарвінізму. Закономірності тваринного світу були поширені на суспільне життя, теорія природного відбору і боротьби за існування перенесена в область соціальних відносин. На місце організму поставлена соціальна група. Насильство соціал-дарвіністи пов'язували з сутністю цивілізації, оголошували війни природними для людського суспільства. У наш час в іншому сенсі проблему насильства трактує соціальна етологія. Австрійський біолог Конрад Лоренц вважає, що соціальне насильство має етологічну природу, зумовлену біогенетично. Людина генетично недосконала і непристосована як біологічний вид, звідси її агресивні прагнення щодо собі подібних. Людина на відміну від тварин здатна на братовбивство. Ця внутрішньовидова агресія слугує збереженню виду. Лоренц доводить, що жага агресії і насильства є вродженим інстинктом людської природи і джерелом будь-яких конфліктів.

Третє. Насильство як абстрактне етичне поняття. У цьому сенсі говорять, що насильство - це зло, що заподіюється людині; застосування сили відносно кого-небудь; ірраціональна дія, що завдає шкоди в тій чи іншій формі; порушення чиїх-небудь інтересів і прав. Отже, насильство трактується як негативне явище. Привабливість такого розуміння насильства в тому, що воно розглядається як протиприродна поведінка і явище, на відміну від біологізаторських трактувань.

Четверте. Психологічне або духовне насильство, що позначає відповідний тиск або шкідливий вплив на чиюсь совість, психіку, переконання, спосіб мислення або духовну свободу. Завдяки такому насильству людину примушують вести себе зовсім не так, як вона того хотіла би. Насильство може бути спрямоване проти життя і здоров’я людини, його честі та гідності, свободи їі волі та духу. Це зачіпає основні права та інтереси особистості, порушує природні права людини.

Таким чином, насильство - це суспільне відношення, під час якого одні індивіди (групи) за допомогою зовнішнього примусу, що становить загрозу життю, підпорядковують собі інших, їх здібності, продуктивні сили, власність [16]. У цьому визначенні наголошується на соціальному характері насильства, та на тому, що воно застосовується у всіх сферах суспільного життя - економічній,

DOI (Article): https: //doi.org/10.36486/np.2019.2.14

(c) Korystin Oleksandr, Sobko Hanna, 2019 Issue 2(44) 2019 http://naukaipravoohorona.com/ 
політичній та духовній. Його суб’єктами і об’єктами можуть бути окремі особистості, класи, групи людей, а також нації і держави.

Враховуючи погляди представників різних наукових сфер, ми приходимо до висновку, що таке багатогранне поняття й досі не має єдиного визначення. Варто зазначити, що античні філософи експлікували переважно “силовий” бік насильства, а представники середньовічної філософії виявили інший, “авторитетний” аспект насильства, пов’язаний з компетентністю, здатністю розпоряджатися, умінням наполягти на своєму.

Показовим є те, що зусиллями провідних представників культурної та політичної еліти другої половини XIX - початку XX століття насильство було міфологізоване та інкорпороване в тоталітарні ідеології нацизму, фашизму й комунізму. Проблема насильства в межах марксистського вчення є, насамперед, проблемою революційного насильства. Крім того, у багатьох філософських, публіцистичних і художніх творах насильство виступало в образі втілення самої творчої сили природи. Здобутки багатьох авторів того часу стали своєрідною інтелектуальною увертюрою до такого розгулу насильства світових війн і революцій, якого ніколи не знала людська історія.

Крім того, насильству притаманні такі ознаки: 1) насильство може охоплювати будь-яке приниження людини, все те, внаслідок чого спричиняється обмеження індивідуальних фізичних та духовних поглядів на життя, те, що заважає оволодівати повнотою можливостей особистісного характеру; 2) насильство може бути прямою формою застосування сили чи погрози такого застосування: вбивство, згвалтування, розбій. Тобто, так звані, тяжкі форми насильницьких дій; 3) насильство може передбачатися в чинному КК, ЦК, КУпАП та інших нормативних документах, а може й не мати такої характеристики; 4) насильство посягає не тільки на тілесну будову чи сексуальну недоторканість людини, а й психічне здоров’я та економічну свободу.

Загалом, проаналізувавши філософські концепції усвідомлення змісту феномену насильства, можна виділити такі закономірності підходів до проблематики насильства: 1) античні поети й філософи приділяли переважну увагу онтології насильства, під яким розуміли невід'ємний елемент світового порядку; 2) представники патристики й схоластики, світоглядні позиції яких були детерміновані церковними догматами, розробляли проблематику насильства в межах метафізичної проблематики; 3) новоєвропейські мислителі перенесли аналіз феномену насильства зі сфери онто-теології в сферу політичної філософії, заклавши основи правового підходу до розуміння насильства, що і понині займає належне місце як у філософській, так і в повсякденній думці; 4) представники німецької класичної філософії збагатили новоєвропейську традицію розуміння насильства етичними підходами, при цьому продовжуючи розробку проблематики насильства в політичному аспекті.

Враховуючи викладене вище, можна дійти висновку, що отримані в цій статті результати створюють методологічне підгрунтя для подальшого удосконалення системи знань щодо поняття насильства та протидії йому.

\section{СПИСОК ВИКОРИСТАНИХ ДЖЕРЕЛ}

1. Йосипів А.О. Насильницька злочинність: детермінанти та протидія органами внутрішніх справ: дис. ... канд. юрид. наук: 12.00.08. Л., 2009. 290 с.

2. Фрагменты ранних греческих философов. М.: Наука, 1989. 576 с.

DOI (Article): https: //doi.org/10.36486/np.2019.2.14

@ Korystin Oleksandr, Sobko Hanna, 2019

Issue 2(4.4) 2019

http://naukaipravoohorona.com/ 
3. Аристотель. Сочинения: в 4 т. М.: Мысль, 1975. Т. 1. 550 с.

4. Августин А. Исповедь. М.: Канон+, 1997. 464 с.

5. Фома Аквинский. Сумма теологии. Ч. I: в 3 т. К.: Ника-Центр, 2003. Т. 2. 336 с.

6. Гоббс T. Сочинения: в 2 т. М.: Мысль, 1991. Т. 2. 736 с.

7. Локк Д. Сочинения: в 3 т. М.: Мысль, 1988. Т. 3. 670 с.

8. Руссо Ж.-Ж. Об общественном договоре. Трактаты. М.: КАНОН-Пресс, 2000. 544 с.

9. Кант И. К вечному миру. Сочинения: в 6 т. М., 1966. Т. 6. С. 257-309.

10. Гердер И.Г. Идеи к философии истории человечества. М.: Наука, 1977. 703 с.

11. Гегель Г.В.Ф. Философия права. М.: Мысль, 1990. 524 с.

12. Маркс К., Энгельс Ф. Сочинения: в 50 т. М.: ГИПЛ, 1961. Т. 20.827 с.

13. Вебер М. Избранные произведения: пер. с нем. / сост., общ. ред. и послесл. Ю.Н. Давыдова; предисл. П.П. Гайденко. М.: Прогресс, 1990. 808 с.

14. Ильин И.А. Собрание сочинений: в 10 т. / сост., вступит. ст. и коммент. Ю.Т. Лисицы. Москва: Русская Книга, 1993-1999. Т. 4: [Понятия права и силы; Общее учение о праве и государстве; О сущности правосознания; О монархии и республике; Из лекций “Понятия монархии и республики"]. Москва: Русская книга, 1994. 624 с.

15. Ильин И.А. Собрание сочинений: в 10 т. / сост., вступит. ст. и коммент. Ю.Т. Лисицы. Москва: Русская Книга, 1993-1999. Т. 5: Основное нравственное противоречие войны; О сопротивлении злу силою; Статьи. Письма. Выступления. Москва: Русская книга, 1996. 608 с.

16. Философия: учеб. для вузов под ред.: В.Н. Лавриненко, В.П. Ратникова. 4-е изд., перераб. и доп. М.: ЮНИТИ. 2008. 735 с.

\section{REFERENCES}

1. Yosipiv A. O. (2009) Nasilnitska zlochinnist: determinanti ta protidiia organami vnutrishnikh sprav. "Violent crime: Determinants and counteraction by internal affairs bodies: dis ... PhD in Law: 12.00.08. L. 290 p. [in Ukrainian].

2. Fragmenty rannikh grecheskikh filosofov. "Fragments of early Greek philosophers" M.: Nauka. 1989. 576 p. [in Ukrainian]. Russian].

3. Aristotel. (1975) Sochineniia. "Aristotle". Essays: in 4 vol. VOL. 1. M.: Mysl, 550 p. [in

4. Avgustin A. (1997) Ispoved. "Confession”. Moscow: M.: Kanon+. 464 p. [in Russian].

5. Foma Akvinsky. (2003) Summa teologii. "Sum of theology". P. I: in 3 vol. K.: Nika- Center. Vol. 2. 336 p. [in Russian].

6. Gobbs T. (1991) Sochineniia. "Essays": in 2 vol. Vol. 2. M.: Mysl. 736p. [in Russian].

7. Lokk D. (1988) Sochinenia. "Essays": in 3 vol. Vol. 3. M.: Mysl. 670 p. [in Russian].

8. Russo ZH.-ZH. (2000) Ob obshchestvennom dogovore. Traktaty. "About the social contract". Treatises M.: KANON-Press. 544 p. [in Russian].

9. Kant I. (1966) K vechnomu miru // Sochineniia. "To eternal peace”. Essays: vol 6. Vol. 6. M. 257-309 pp. [in Russian].

10. Gerder I. H. (1977) Idei k filosofii istorii chelovechestva. "Ideas for the philosophy of human history”. M.: Nauka. 703 p. [in Russian].

11. Gegel H. V. F. (1990) Filosofiia prava. "Philosophy of law". M.: Mysl. 524 p. [in Russian]. Russian].

12. Marks K., Engels F. (1961) Sochinenia. "Essays": in 50 vol. Vol. 20. M.: GIPL. 827 p. [in

13. Veber M. (1990) Izbrannyie proizvedeniia: Per. s nem. "Selected works": Transl. from Germ. / Composition, commonly. edited. and after. Yu.N. Davydova; preface. P.P. Gaidenko M.: Progress. 808 p. [in Russian].

14. Ilin I.A. (1994) Sobraniie sochinenii: v 10 t. / sost., vstupit. st. i komment. Yu.T. Lisitsy. Moskva: Russkaia Kniga, 1993-1999. T. 4: [Poniatiia prava i sily; Obshcheie ucheniie o prave i gosudarstve; O sushchnosti pravosoznaniia; O monarkhii i respublike; Iz lektsiy "Poniatiia monarkhii i respubliki"]. "Collected works: in 10 vol. /composition, opening page and comment. Yu.T. Lysytsi. Moscow: Russian Book, 1993-1999. vol. 4: [Concepts of law and force; General doctrine about law and state; About essence of legal consciousness; About monarchy and republic; From lectures "Concepts of monarchy and republic"]". Moscow: Russian Book, 1994. 624 p. [in Russian].

15. Ilin I.A. (1996) Sobranie sochineniy: v 10 t. / sost., vstupit. st. i komment. Yu.T.Lisitsy. Moskva: Russkaya Kniga, 1993-1999. T. 5: [Osnovnoe nravstvennoe protivorechie voyny; O soprotivlenii

DOI (Article): https://doi.org/10.36486/np.2019.2.14

(C) Korystin Oleksandr, Sobko Hanna, 2019 
zlu siloyu; Stati. Pisma. Vystupleniia]. "Collected Works: 10 vol. / Comp., Enter. Art. and comments. Yu.T. Lisitsy. Moscow: The Russian Book, 1993-1999. V. 5: [The basic moral contradiction of war; About resisting evil by force; Articles. Letters Speeches]". Moscow: The Russian Book, 1996. 608 p. [in Russian].

16. Filosofiya: ucheb. dlya vuzov pod red.: V.N. Lavrinenko, V.P. Ratnikova. "Philosophy": studies. for universities ed.: V.N Lavrinenko, V.P. Ratnikov. [4th ed., Pererab. and add.]. M.: UNITY. 2008. 735 p. [in Russian].

UDC 340.113

\section{Korystin Oleksandr, \\ Doctor of Juridical Sciences, Professor, Deputy Director, State Research Institute MIA Ukraine, Kyiv, Ukraine, ORCID ID 0000-0001-9056-5475;}

Sobko Hanna,

Candidate of Juridical Sciences, Associate Professor, Professor of the Department, Odessa State University of Internal Affairs, Odesa, Ukraine, ORCID ID 0000-0002-5938-3400

\section{METHODOLOGICAL BASIS FOR UNDERSTANDING THE PHENOMENON OF “VIOLENCE” IN CRIMINAL LAW}

The article examines the views of representatives of various scientific schools on the definition of the phenomenon of "violence", in particular, with an emphasis on the features of its relationship with the notion of "coercion". It is noted that both coercion and violence are direct, individualized and mediated, encoded in the institutes and mechanisms of society, hidden and open, physical and psychological. Any violence is coercion, but not any coercion is violence. The article states that the category of "violence" is considered in various aspects: historical, sociological, psychological, legal, anthropological, biological, political. The scientific search within the framework of the study allowed us to look at the phenomenon of "violence" in the philosophical sense, which is an integral part of the overall development of mankind. On the basis of scientific research, the authors come to the conclusion that such a multi-faceted concept still does not have a single definition. It is noted that ancient philosophers have explored the "force" side of violence, and representatives of medieval philosophy have revealed another, "authoritative" aspect of violence associated with competence, ability to dispose, ability to insist on their own. The beginning of the 20th century was marked by the emergence of many philosophical and journalistic works, in which violence appeared as a vivid image of the embodiment of the most creative force of nature. In the article, having examined the opinions and positions of scientists, the general interpretations of the essence of the phenomenon of violence are outlined and highlighted, and attention is focused on the features of violence. In addition, it is noted that the results obtained in this article create a methodological basis for further improvement of the knowledge system about the concept of violence in criminal law.

Keywords: violence, coercion, category, concept, phenomenon of violence, philosophical and legal concepts, methodological aspects.

Отримано 07.06.2019

DOI (Article): https://doi.org/10.36486/np.2019.2.14

(C) Korystin Oleksandr, Sobko Hanna, 2019 


\section{Кулик Олександр Георгійович,} доктор юридичних наук, старший науковий співробітник, завідувач науково-дослідної лабораторії ДНДІ МВС України,

м. Київ, Україна

ORCID ID 0000-0002-5172-8996

\section{КРИМІНАЛЬНА СИТУАЦІЯ В УКРАЇНІ: СУЧАСНІ ТЕНДЕНЦІї}

Минуло шість років з моменту запровадження в Украйні нової системи реєстрачї та обліку злочинів. У статті на основі аналізу статистичних даних, які містяться у ЄӘиному звіті про кримінальні правопорушення (форма № 1), затвердженому наказом Генеральної прокуратури України за погодженням з Держкомстатом України 23.10.2012, за 2013-2018 рр. визначені основні тенденції розвитку сучасної кримінальної ситуації в крайні та фактори, які їх обумовлюють.

Зроблено висновок щодо прочесу трансформачії злочинності сочіалістичного суспільства у злочинність ринкового суспільства при визначальному впливі на кримінальну ситуацію динаміки корисливих посягань на власність.

Ключові слова: кримінальна ситуачія, злочинність, структура злочинності, динаміка злочинності, види злочинів, показники злочинності, фактори злочинності.

Термін “кримінальна ситуація” використовується у правових наукових публікаціях причому в різних смислах. Криміналісти розглядають кримінальну ситуацію як сукупність умов та обставин вчинення злочину [1, с. 73, 74]. У кримінології цей термін вживається в низці робіт для позначення стану, структури та динаміки злочинності на певній території за певний період часу. Ми б назвали таке розуміння цього терміна вузьким. Водночас останніми роками це формулювання використовується в публікаціях, присвячених аналізу злочинності, в білыш широкому смислі й охоплює “ситуацію із злочинністю” [2, с. 290] на певній території за певний період часу, тобто як стан, структуру та динаміку злочинності, так і фактори, які впливають на неї, в тому числі й стан та діяльність правоохоронних та судових органів, які здійснюють протидію злочинності [3, с. 59, 60; 4, с. 4-8]. Саме в такому широкому розумінні ми вживатимемо цей термін у нашій роботі.

Аналіз кримінальної ситуації в країні є необхідною умовою розроблення адекватної оцінки стану та структури злочинності, прогнозу змін її показників, які можуть відбутися у майбутньому, визначення та реалізації ефективної системи заходів протидії злочинним посяганням. Такі дослідження постійно проводяться як в Україні, так і в багатьох інших країнах світу.

Минуло шість років з моменту запровадження нової системи реєстрації та обліку злочинів в України, відповідно було отримано достатньо значні часові ряди всієї сукупності показників облікованої ${ }^{1}$ злочинності. Це дозволяє встановити

1 В подальшому термін “облікована” вживатися не буде, але всі показники будуть стосуватися облікованої (зареєстрованої) злочинності або злочинів певних видів.

DOI (Article): https://doi.org/10.36486/np.2019.2.15

(C) Kulyk Oleksandr, 2019 
нові тенденції, які вже проявилися у сучасній кримінальній ситуації в Україні, а також зробити висновки щодо її сутності та закономірностей подалышого розвитку. Це і є метою нашої статті.

Робота базується на результатах аналізу статистичних даних, які містяться у Сдиному звіті про кримінальні правопорушення (форма № 1), затвердженому наказом Генеральної прокуратури України за погодженням із Держкомстатом України 23.10.2012, за 2013-2018 рр. [5].

За результатами зазначеного аналізу можна визначити такі тенденції сучасної кримінальної ситуації в Україні.

1. Відсутність стабільної тенденщї динаміки кількості облікованих злочинів, суттєві коливання цього показника протягом зазначеного періоду. Якщо з часу набуття Україною незалежності у динаміці злочинності в країні спостерігалися чіткі тенденції (значне зростання у 1991-1995 рр., поступове зниження у 19962008 рр., зростання у 2009-2011 рр.), то після переходу в кінці 2012 р. на нову систему реєстрації та обліку злочинів зміни стану злочинності мали суперечливий характер. У 2013 р. було обліковано 563560 посягань, що на 12,8 \% більше розрахункового показника за 2012 р. (499635) (рис. 1). Таке помітне зростання зумовлене здійсненням органами поліції максимально повної реєстрації та обліку злочинів. У 2014 р. кількість злочинів зменшилася на 6,1 \% і становила 529139, що стало реакцією правоохоронної системи на значне зростання обсягу роботи щодо розкриття та розслідування злочинів і відповідне перевантаження її працівників.

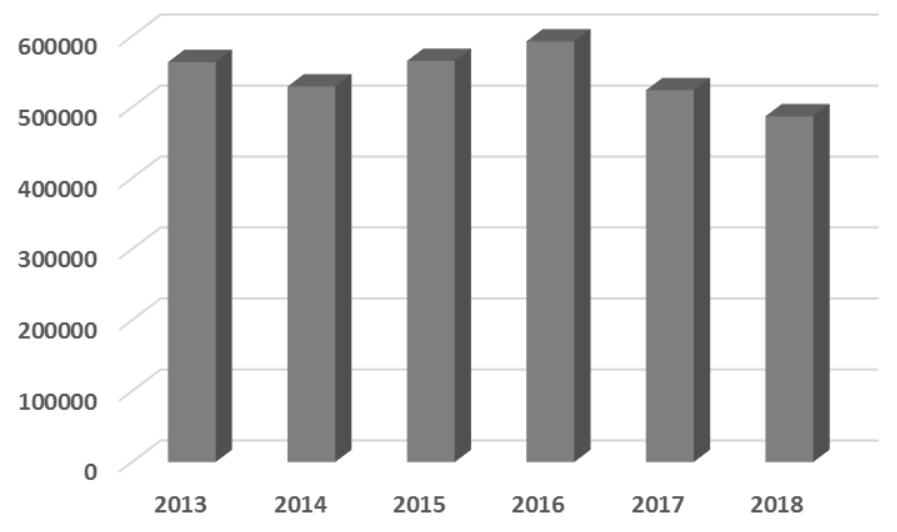

Рис. 1. Динаміка злочинів в Україні у 2013-2018 рр.

У наступні два роки знову сталося збілышення кількості облікованих злочинів на 6,8 \% та 4,9 \% відповідно у 2016 р. цей показник досяг позначки 592604. За ці роки відбулося суттєве погіршення соціально-економічної ситуації, продовжилися масштабні бойові дії на Сході країни, що зумовило зростання злочинності, органи поліції максимально повно облікували їх і намагалися здійснювати кримінальні провадження відповідно до чинного кримінального процесуального законодавства. Так, за останні два роки розглядуваного періоду було зафіксовано зменшення числа злочинів у 2017 р. до 523911 (-11,6 \%) та у 2018 р. - до 487133 (-7,0 \%). Це скорочення відбулося в умовах дії в країні низки як криміногенних (гальмування економічного розвитку, низький рівень матеріального забезпечення значної частини населення тощо), так і антикриміногенних чинників (втрата контролю

DOI (Article): https://doi.org/10.36486/np.2019.2.15

(C) Kulyk Oleksandr, 2019 
над територією Автономної Республіки Крим, м. Севастополь та частиною територій Донецької та Луганської областей з помітним зменшенням кількості кримінально активного населення, скорочення чисельності молодших вікових груп населення, які мають найвищий рівень кримінальної активності тощо). На це зниження, ймовірно, вплинула також установка керівництва поліції на певне обмеження реєстрації та обліку діянь з ознаками злочинів для того, щоб обсяг кримінальних процесуальних дій, які вони мають здійснити в межах кримінальних проваджень, відповідав їх нинішнім можливостям.

2. Збереження в цілому усталеного розподілу регіонів України за рівнем злочинності при помітному збільшенні його в окремих із них. Для структури регіонів за величиною коефіцієнта інтенсивності (рівнем) злочинності є характерним: стабільно високі показники у східних, південних областях та столиці - регіонах з високим рівнем промислового розвитку та урбанізації; середні - у центральних та північних регіонах; низькі - у західних та окремих центральних областях, у яких переважає сільське населення і зберігається нижчий рівень розвитку промисловості.

У 2018 р. регіони країни так розподілилися за величиною зазначеного показника: регіони з найвищим коефіцієнтом інтенсивності злочинності - м. Київ (2046); регіони з дуже високим коефіцієнтом інтенсивності злочинності (від 1511 до 1678) - Миколаївська, Кіровоградська, Запорізька, Херсонська, Полтавська області; регіони з високим коефіцієнтом інтенсивності злочинності (від 1275 до $1413)$ - Дніпропетровська, Чернігівська, Одеська, Харківська, Черкаська; регіони із середнім коефіцієнтом інтенсивності злочинності (від 1019 до 1152) Житомирська, Київська, Сумська, Львівська області; регіони з низьким коефіцієнтом інтенсивності злочинності (від 799 до 895) - Волинська, Рівненська, Хмельницька, Закарпатська, Чернівецька, Вінницька; регіони з дуже низьким коефіцієнтом інтенсивності злочинності (від 478 до 671) - Тернопільська, Донецька, ІваноФранківська та Луганська області.

Упродовж зазначеного періоду значно виріс коефіцієнт інтенсивності злочинності у Миколаївській (2013 р. - 1109, 2015 р. - 1671, 2018 р. - 1678), Полтавській (2013 р. - 1218, 2015 р. - 1625, 2018 р. - 1511), Чернігівській (2013 р. 948, 2015 р. - 1497, 2018 р. - 1392) областях, які з 2014-2015 рр. почали входити до групи регіонів з високим значенням цього показника, та Львівській області (2013 р. - 813, 2015 р. - 1308, 2018 р. - 1019), у якій він збільшився від низького до середнього рівня. Водночас внаслідок втрати контролю за частиною території Донецької та Луганської областей в них відбулося значне зменшення коефіцієнтів інтенсивності злочинності, в результаті якого ці регіони опинилися у групах 3 низьким та дуже низьким рівнем злочинності.

3. Визначальний вплив на кримінальну ситуацію посягань, вчинених у містах та селищах міського типу (CMT). Міські злочини становили абсолютну більшість усіх злочинних посягань, у середньому 77,6 \%. Протягом аналізованого періоду відсотковий показник міських злочинів зростав, але повільно. У 2018 р. він становив 78,3 \%. Частка сільських злочинів коливалася в межах 19-20\%, а у 2018 р. дорівнювала 19,1\%. Таке стабільне співвідношення відсоткових показників міських та сільських злочинів зумовлено тим, що роки їх зростання та зниження в цих двох типах поселень збігалися.

4. Переважання у структурі злочинності за ступенем тяжкості посягань середньої тяжкості та тяжких злочинів. Упродовж розглядуваного періоду найчи-

DOI (Article): https://doi.org/10.36486/np.2019.2.15

(ㄱ) Kulyk Oleksandr, 2019 
сельнішою була група злочинів середньої тяжкості, причому їх частка серед всіх облікованих злочинів коливалася від 39 \% до 41 \% (рис. 2). 32014 р. другими за чисельністю стали тяжкі злочини. Їх відсоток у 2014-2017 рр. збільшився з 27,7 \% до 37,8 \%, тобто майже зрівнявся 3 показником посягань середньої тяжкості. У 2018 р. сталося зменшення цього показника до 34,5 \%. Частка злочинів невеликої тяжкості у 2014-2017 рр. скоротилася з 28,7 \% до 20,4 \%, а у 2018 р. становила 21,9 \%. Відсотковий показник особливо тяжких злочинів у 2014 р. збільшився 3 2,4 \% до 4,9 \%, у наступному році дорівнював 3,8 \%, а у 2016-2018 рр. перебував на рівні $3,2 \%$.

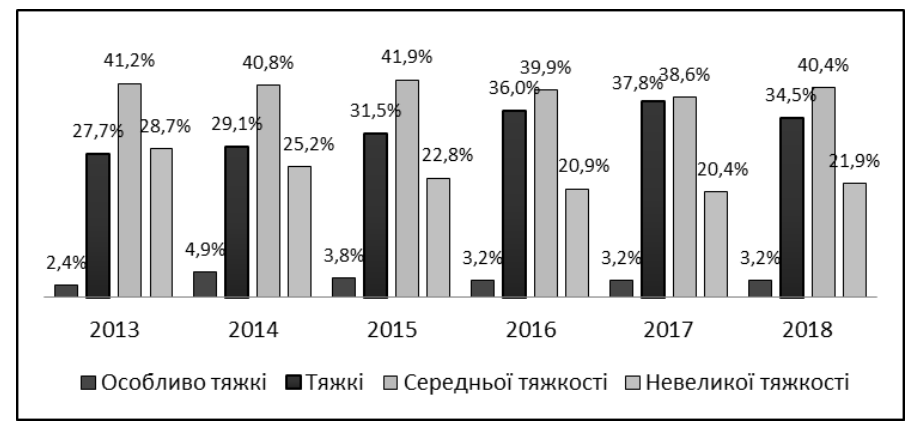

Рис. 2. Структура злочинів за ступенем тяжкоті в Україні у 2013-2018 рр.

Посягання середньої тяжкості та тяжкі злочини становлять майже $3 / 4$ всіх злочинів, їх динаміка визначально впливає на динаміку злочинності в країні. Зниження чисельності злочинів середньої та, особливо, невеликої тяжкості за останні два роки зумовлене прагненням знизити навантаження на правоохоронну систему, передусім органи поліції, щоб вони могли ефективно протидіяти більш тяжким злочинам.

5. Збереження високого рівня злочинів проти життя та здоров'я особи при переважанні тендениї до їх зниження. Після сплеску у 2013 р. (71749, зростання у 3,9 рази) чисельність посягань цієї категорії постійно зменшувалася і становила у 2017 р. 38274 (-46,7 \%) і лише в останньому році періоду, що аналізується, зниження припинилося (39164, $+2,3$ \%) (рис. 3).

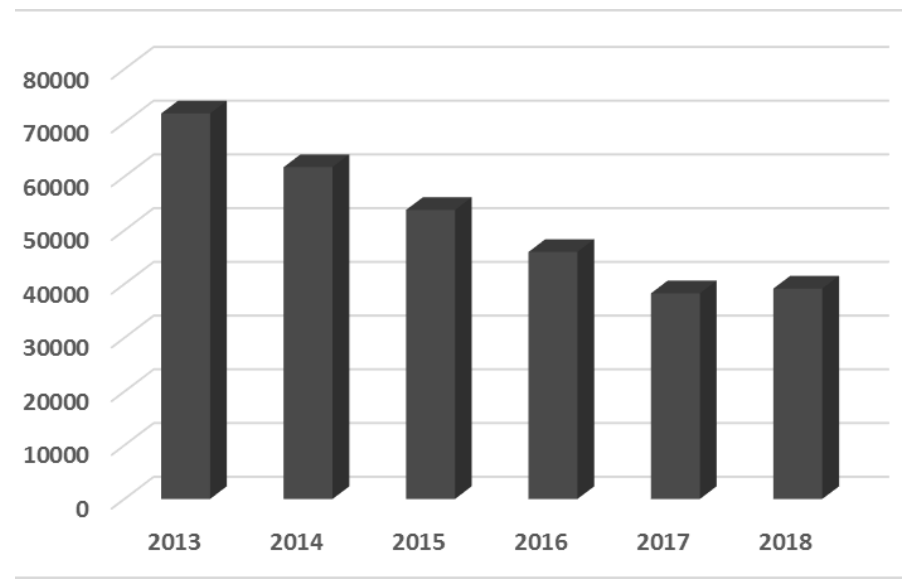

Рис. 3. Динаміка злочинів проти життя та здоров’я особи в Україні у 2013-2018 рр.

DOI (Article): https://doi.org/10.36486/np.2019.2.15

(C) Kulyk Oleksandr, 2019 
Динаміка умисних вбивств (ст.ст. 115-118 КК) мала схожий характер, але були й певні відмінності. Найбільш значне зростання іхх кількості відбулося не у 2013 р. а у 2014 р. (11532, +94,7 \%), у наступні три роки відповідний показник зменшувався і дорівнював у 2017 р. 5180 (-55,1\%). У 2018 р. кількість таких діянь збільшилося на $8,1 \%$ і дорівнювало 5600. Число так званих очевидних умисних вбивств, яке окремо обліковується з 2013 р., зросло з 2042 до 4920 у 2014 р., а в наступні роки постійно зменшувалося і становило у 2018 р. 1547, що у 2,3 рази менше рівня $2014 \mathrm{p}$.

Суттєве зростання кількості умисних вбивств у 2013-2014 рр. пов'язано 3 реалізацією нових нормативних положень щодо порядку дій працівників правоохоронних органів у разі надходження до них інформації про смерть людини [6]. До ЄРДР почали вносити інформацію про певну кількість природних смертей, фактів зникнення без вісті, і кваліфікувати такі події як умисні вбивства. Ще одним вагомим фактором зростання кількості таких злочинів у 2014 р. було інтенсивне ведення військових дій у зоні АТО, випадки загибелі людей, які кваліфікувалися саме як умисні вбивства.

Аналогічна динаміка характерна й для інших найбільш небезпечних та поширених видів злочинів цієї спрямованості - умисних тяжких тілесних ушкоджень (2013 р.: 3026; 2017 р.: 2096 (-30,7 \%); 2018 р.: 2130 (+1,6 \%)) та умисних тілесних ушкоджень середньої тяжкості (2013 р.: 5402, 2017 р.: 3077 (-43,0 \%); 2018 р.: $3139(+2,0 \%))$.

Окремо слід виділити такий вид злочинів цієї категорії, як легкі тілесні ушкодження. У 2013 р. було забезпечено їх максимально повну реєстрацію, чисельність посягань цього виду склала 50018, внаслідок чого ці злочини стали найбільш поширеними серед усіх діянь зазначеної спрямованості (69,7 \%). У наступні чотири роки кількість таких діянь постійно зменшувалася, особливо інтенсивно у 2014 p. (-24,3 \%) та 2017 p. (-20,6 \%), і склала у 2017 р. 23789, а у 2018 р. залишилася на минулорічному рівні 23447, (-1,4 \%). Частка зазначених посягань серед всіх злочинів цієї спрямованості зменшилася до 59,9\%.

7. Значне переважання посягань проти власності серед усіх злочинів при коливаннях показників найбільш поширених їх видів. Протягом 2014-2016 pp. їх частка серед всіх злочинів зросла з 59,4 \% до 68,4 \%, а в останні два роки аналізованого періоду скоротилася до 62,4 \%. Після реєстрації у 2013 р. 334821 злочину цієї категорії їх кількість у наступному році зменшилася на 7,0 \% і становила 311342. Упродовж наступних двох років цей показник зростав - 2016 р. 405549 (+30,3\%). У 2017-2018 рр. кількість злочинів проти власності зменшилася на $17,2 \%$ та 9,5 \% відповідно і становила 303850 (рис. 4). Таким чином, динаміка злочинів проти власності через їх домінування у структурі злочинності визначально впливає на динаміку всіх облікованих злочинів.

DOI (Article): https://doi.org/10.36486/np.2019.2.15

(C) Kulyk Oleksandr, 2019 


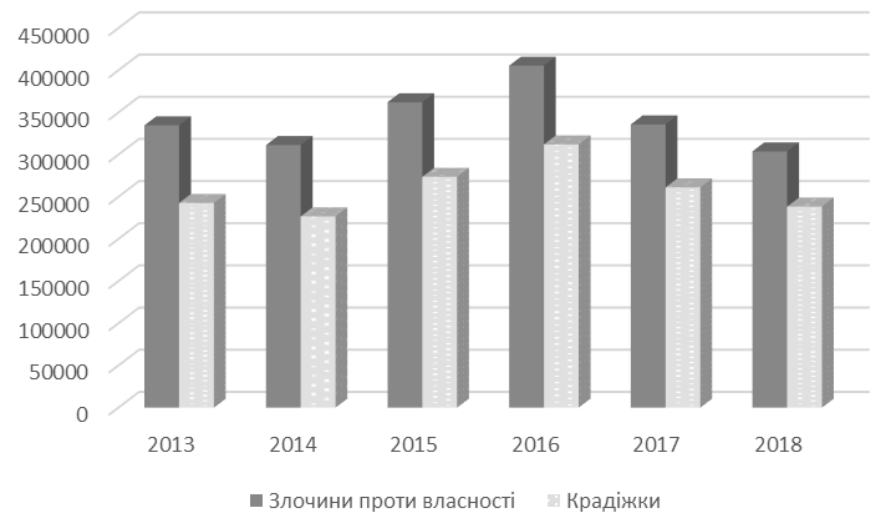

Рис. 4. Динаміка всіх злочинів проти власності та крадіжок в Україні у 2013-2018 рр.

Серед посягань проти власності та серед усіх облікованих злочинів абсолютну більшість складали крадіжки. Їх частка серед злочинів цієї спрямованості за ці роки збільшилася з 72,5 \% до 78,5 \%, а відсотковий показник серед усіх злочинів зріс з 43,1 \% у 2013 р. до 52,7 \% у 2016 р., а у 2018 р. зменшився до 49,0 \%. Динаміка крадіжок природно була такою ж, як і всіх злочинів цієї категорії: у 2014 р. скорочення до 226833 (-6,6 \%), у 2015-2016 рр. - зростання до 312172 (+37,6 \%), у 2017-2018 рр. - зниження до 238492 (-23,6 \%).

Слід виділити два різновиди крадіжок, які спричиняють значну матеріальну шкоду громадянам і часто вчиняються організованими групами у вигляді промислу, тобто суттєво ускладнюють кримінальну ситуацію в країні. Це квартирні крадіжки та випадки незаконного заволодіння транспортними засобами ${ }^{2}$, які найчастіше здійснюються шляхом крадіжки. На тлі погіршення криміногенної обстановки в країні у 2014-2016 рр. кількість крадіжок із квартир постійно зростала. Якщо у 2013 р. вона становила 17450, то у 2016 р. - 27204 (зростання більше ніж у півтора рази). У наступні два роки в результаті суттєвого підвищення рівня сек'ютеризації житлового сектору число таких діянь зменшилося на 7,5 \% та 19,6 \% відповідно і склало 20228. Схожою була ситуація з посяганнями на транспортні засоби. Після сплеску у 2014 р. (+86,1%) у наступні два роки їх чисельність коливалася $(-9,3 \%$ та $+6,5$ \% відповідно), але залишалася значною і становила у 2016 р. - 12205. У наступні два роки кількість таких діянь істотно зменшувалася (-26,1 \% та -26,3\% відповідно) і становила у 2018 р. - 6642. Упродовж зазначеного періоду у середньому понад 59 \% таких діянь становили посягання на автомобілі.

У цілому схожою була також динаміка найбільш поширених корисливо-насильницьких злочинів - грабежів та розбоїв. Так, кількість грабежів у 2014 р. зменшилася з 22695 до 20541 (-9,5 \%), у наступні два роки зросла до 27199 (+32,4 \%), а в останні два роки суттєво зменшилася (-33,3 \% та $-23,7$ \%) і становила 13838. Кількість розбої навпаки у 2014 р. збільшилася проти попереднього року

${ }^{2}$ Ми розглядаємо цей вид злочину серед посягань проти власності, оскільки, на думку більшості вчених, яку ми поділяємо, він за своєю сутністю належить саме до вказаної категорії злочинів.

DOI (Article): https://doi.org/10.36486/np.2019.2.15

CC Kulyk Oleksandr, 2019 
на 36,4\% і склала 3895, у наступні два роки спочатку зменшилася $(-8,7$ \%), а потім зросла $(+9,8$ \%) і відповідала 3904 , а в останнє дворіччя аналізованого періоду зменшилася на 23,0 \% та 24,7 \% відповідно і становила 2263.

Несприятлива соціально-економічна ситуація зумовила поширення майже всіх видів посягань на власність у 2015-2016 рр. Помітне зменшення чисельності посягань цієї спрямованості в останні два роки розглядуваного періоду зумовлене підвищенням рівня захищеності об’єктів власності, які найчастіше стають предметом посягань, а також обмеженням реєстрації та обліку корисливих злочинів, які не становлять суспільної небезпеки.

8. Тендениії скорочення кількості груп злочинів без потерпілого, чисельність яких залежить від активності підрозділів поліщї щодо їх виявлення, протягом більшої частини аналізованого періоду. На початку аналізованого періоду відбувалося зниження чисельності основних груп злочинів без потерпілого. У 20142016 рр. кількість злочинів у сфері обігу наркотичних засобів, психотропних речовин, їх аналогів або прекурсорів та інших злочинів проти здоров'я населення (наркозлочинів) зменшилася з 33982 до 23029 (-32,2 \%), у сфері службової діяльності та професійної діяльності, пов'язаної з наданням публічних послуг, з 16586 до 14820 (-10,6\%), а у сфері господарської діяльності - з 11104 до 6297 $(-43,3$ \%) у 2017 р. Тенденція зниження у ці роки була характерною також для основних показників організованої злочинності. У 2014-2016 рр. кількість виявлених організованих груп та злочинних організацій (ОГ та 3О) зменшилася з 172 до 102(- 40,7 \%), виявлених осіб, які вчинили злочини у складі ОГ та 3О, - з 662 до 368 (- 44,4 \%) та злочинів, вчинених ОГ та 3О, - з 1984 до 1331 (-32,9 \%). Це зниження стало наслідком деморалізації працівників міліції (поліції), здій-снення заходів щодо перебудови їх структурної перебудови та скорочення (БНОН) або ліквідації (ГУБОЗ), що природно позначилося на ефективності їх діяльності.

За рахунок вжиття низки організаційно-управлінських заходів у 2017 р. тенденцію падіння результатів роботи по зазначених злочинах вдалося припинити, і відбулося покращення більшості її показників. Так, кількість виявлених наркозлочинів збільшилася відразу на 26 \% і 2017 р. становила 29010. Після такого зростання навантаження активність працівників підрозділів протидії наркозлочинності у 2018 р. дещо зменшилася і кількість виявлених посягань становила 27007 (-6,9 \%). У 2017 р. також різко зросла чисельність встановлених злочинів у сфері службової діяльності та професійної діяльності, пов'язаної з наданням публічних послуг, - 19234 (+29,8 \%). У наступному році цей показник також трохи збілышився $(19909,+3,5$ \%). На відміну від перших двох груп злочинів без потерпілого кількість посягань у сфері господарської діяльності у 2018 р. лише перестала знижуватися і залишилася на рівні минулого року 6334 (+0,6 \%). Найбільш суттєво упродовж 2017-2018 рр. збільшилися показники проявів організованої злочинності: виявлених ОГ та $3 \mathrm{O}$ - до 258 (у 2,5 рази); осіб, які вчинили злочини у складі ОГ та 3О, - до 1064 (у 2,9 рази); злочинів, які вчинили ОГ та $3 О$ - до $2283(+71,5 \%)$.

Наскільки тенденція підвищення рівня діяльності підрозділів поліції за цими напрямами протидії злочинності буде усталеною, з'ясується у наступні роки.

DOI (Article): https://doi.org/10.36486/np.2019.2.15

(c) Kulyk Oleksandr, 2019 
9. Високий рівень злочинності проти громадської безпеки. Кількість злочинів проти громадської безпеки збільшилася у 2014 р. більше ніж у півтора рази проти попереднього і становила 11947. Таке значне зростання пов'язано із загостренням суспільно-політичної ситуації в країні та веденням масштабних бойових дій у зоні АТО. У наступні роки попри певні коливання (2015 р.: -2,1 \%; 2016 р.: -6,8 \%; 2017 р.: +8,0 \%) кількість таких посягань залишалася значною і у 2018 р. склала 10711 (-9,0\%).

Активність сепаратистських угруповань як у зоні ОСО, так і за ї̈ межами призвела до високого рівня проявів тероризму та організованої злочинності. Кількість випадків створення злочинних організацій становила у 2013 р. - 8, у 2016 р. - 33, у 2018 р. - 84; терористичних актів - 4, 1865 та 950; створення терористичної групи чи терористичної організації - 1, 391 та 175 відповідно.

Значною загрозою для суспільства стало створення непередбачених законом воєнізованих або збройних формувань. У 2014 р. чисельність таких фактів зросла з 0 до 457, у 2015 р. - до 543, а у 2018 р. - 396. Створення таких формувань порушує виключне право держави на застосування сили і тим самим руйнує саму державну владу в країні.

Ведення масштабних бойових дій в зоні ОСО і залучення до них значної кількості військовослужбовців та правоохоронців мали об'єктивним наслідком поширення випадків незаконного поводження зі зброєю, бойовими припасами або вибуховими речовинами. У 2014 р. було обліковано 7228 (+4,3\%) таких діянь, у 2017 р. - 8002 (+10,7 \% до рівня 2014 р.), а у 2018 р. - 7466 (-6,7 \%). Такі діяння становили у середньому 68,1 \% усіх злочинів цієї спрямованості. Поширення цих злочинів можна розглядати як окремий фактор погіршення кримінальної ситуації в країні у цілому.

10. Зростання кількості злочинів, які вчиняються рещидивістами. У 20142016 рр. чисельність злочинів, провадження за якими направлені до суду, вчинених особами, які раніше вчиняли злочини, зменшилася з 62625 до 50510 (-19,3 \%), а в наступні два роки зросла більше ніж у півтора рази і становила 77200. Попри ці коливання частка таких злочинів серед усіх посягань цієї категорії постійно збільшувалася (2013 р.: 29,0 \%; 2014 р.: 34,8 \%; 2017 р.: 36,3 \%) і у 2018 р. становила 43,1 \%. Зростання відсотка злочинів, учинених рецидивістами, зумовлене формуванням у країні маргінального прошарку населення з підвищеною кримінальною активністю. У сучасній кримінальній ситуації в країні саме такі особи частіше піддаються впливу системи кримінального судочинства.

Узагальнюючи зазначене вище, можна констатувати, що в Україні ще продовжується процес трансформації злочинності соціалістичного суспільства у злочинність ринкового суспільства. Визначально впливає на кримінальну ситуацію в країні динаміка корисливих посягань на власність. Для більш точної оцінки стану злочинів проти життя і здоров’я особи необхідно вдосконалити порядок реєстрації та обліку таких діянь, передусім умисних убивств. Виявлення низки небезпечних видів злочинів без потерпілого суттєво обмежується нинішнім рівнем кадрового та матеріально-технічного забезпечення діяльності відповідних підрозділів Національної поліції України. Дестабілізуючий вплив на кримінальну ситуацію в країні чинить поширення групових порушень громадського порядку, ство-

DOI (Article): https://doi.org/10.36486/np.2019.2.15

() Kulyk Oleksandr, 2019 Issue 2(4.4) 2019 http://naukaipravoohorona.com/ 
рення незаконних формувань, які схильні до протизаконних силових акцій для досягнення певних політичних та інших цілей. В країні формується маргінальний прошарок населення, схильного до вчинення злочинів, який все частіше стає об’єктом впливу системи кримінального судочинства.

Вважаємо, що процес трансформації триватиме ще певний час і буде прискорюватися або гальмуватися на тлі покращення або погіршення соціальноекономічної ситуації в країні.

\section{СПИСОК ВИКОРИСТАНИХ ДЖЕРЕЛ}

1. Волчецкая Т.С. Криминалистическая ситуалогия: монография. / под ред. проф. Н.П. Яблокова. Москва: Калинингр. ун-т., 1997. 248 с.

2. Российская криминологическая энциклопедия / под общ. ред. А.И. Долговой. М.: Издво НОРМА, 2000. 808 с.

3. Ситковский А.Л., Лесников Г.Ю., Афанасьева О.Р. и др. Комплексный анализ преступности и прогноз ее развития на территории Российской Федерации и Украины до 2013 года: монография. М.: ФГКУ “ВНИИ МВД России", 2011. 144 с.

4. Антонян Ю.М., Бражников Д.А., Гончарова М.В. и др. Комплексный анализ состояния преступности в Российской Федерации и расчетные варианты ее развития: аналитический обзор. М.: ФГКУ “ВНИИ МВД России”, 2018. 86 с.

5. Єдиний звіт про кримінальні правопорушення (форма № 1) за 2013-2018 pp. URL: https://www.gp.gov.ua/ua/statinfo.html (дата звернення: 17.12.2018).

6. Порядок взаємодії між органами внутрішніх справ, закладами охорони здоров'я та органами прокуратури України при встановленні факту смерті людини, затверджений спільним наказом Міністерства внутрішніх справ України, Міністерства охорони здоров'я України, Генеральної прокуратури України від 28.11.2012 № 1095/955/119. URL: https://zakon.rada.gov.ua/ laws/show/ z1299-17 (дата звернення: 23.05.2019).

\section{REFERENCES}

1. Volchetskaia T.S. (1997) Krymynalystycheskaia sytualohyia: Monohrafiia. "Criminalistic situation": monograph. / Under the editorship of Prof. N.P. Yablokov. Moscow: Kaliningrad Unt. 248 p. [in Russian].

2. Rossiyskaia kriminologicheskaia entsiklopediia. "Russian criminological encyclopedia" / under the general. ed. A.I. Dolhovoi. M.: Publishing house NORMA, 2000.808 p. [in Russian].

3. Sitkozsky A.L., Lesnikov G.YU., Afanasieva O.R. i dr. (2013) Kompleksnyi analiz prestupnosti i prognoz yeye razvitiia na territorii Rossiyskoi Federatsii i Ukrainy do 2013 goda: monografiia. "Comprehensive analysis of crime and the forecast of its development in the Russian Federation and Ukraine until 2013": a monograph. M.: FGKU VNII Ministry of Internal Affairs of Russia.144 p. [in Russian].

4. Antonian Yu.M., Brazhnikov D.A., Goncharova M.V. i dr. (2018) Kompleksnyi analiz sostoianiia prestupnosti v Rossiiskoi Federatsii i raschetnyie varianty yeye razvitiia: analiticheskiy obzor. "Complex analysis of the state of crime in the Russian Federation and estimated variants of its development”: analytical review. Moscow: FGKU VNII MVD of Russia. 86 p. [in Russian].

5. Yedynyi zvit pro kryminalni pravoporushennia (forma № 1) za 2013-2018 rr. "Uniform Report on Criminal Offenses (Form No. 1) for 2013-2018”. URL: https://www.gp.gov.ua/en/ statinfo.html (date of application: 17.12.2018) [in Ukrainian].

6. Poriadok vzaiemodii mizh orhanamy vnutrishnikh sprav, zakladamy okhorony zdorovia ta orhanamy prokuratury Ukrainy pry vstanovlenni faktu smerti liudyny, zatverdzhenyi spilnym nakazom Ministerstva vnutrishnikh sprav Ukrainy, Ministerstva okhorony zdorovia Ukrainy, Heneralnoi prokuratury Ukrainy vid 28.11.2012 № 1095/955/119. "The order of interaction between lawenforcement bodies, health care institutions and public prosecutor's offices of Ukraine in establishing the fact of death of a person, approved by joint order of the Ministry of Internal Affairs of Ukraine, Ministry of Health of Ukraine, Prosecutor General of Ukraine of 28.11.2012 No. 1095/955/119" .

DOI (Article): https://doi.org/10.36486/np.2019.2.15

(c) Kulyk Oleksandr, 2019 Issue 2(44) 2019 http://naukaipravoohorona.com/ 
URL: https://zakon.rada.gov.ua/laws/show/ z1299-17 (date of application: 23.05.2019) [in Ukrainian].

UDC 343.97

Kulyk Oleksandr,

Doctor of Juridical Sciences, Senior Research Associate, Chief of the Research Laboratory, State Research Institute MIA Ukraine, Kyiv, Ukraine, ORCID ID 0000-0002-5172-8996

\section{CRIMINAL SITUATION IN UKRAINE: MODERN TRENDS}

Currently, six years have passed since the introduction of the new crime registration and recording system in Ukraine. Based on the analysis of statistical data contained in the Unified Report on Criminal Offences (Form No. 1), approved by the order of the Prosecutor General's Office of Ukraine in coordination with the State Statistics Service of Ukraine from 23.10.2012 to 2013-2018, the article identifies the main trends in the development of the current criminal situation in the country and the factors that predetermine.

These trends include:

the lack of a stable trend in the number of recorded crimes, significant fluctuations of this indicator during the specified period, both upwards and downwards;

maintaining consistently high crime rates in the eastern and southern regions and the capital; medium - in the central and northern regions; low - in the western and separate central areas. It was stated a marked increase in the crime rate in the Nikolaev, Poltava and Chernihiv regions;

determining influence on the criminal situation of crimes committed in cities and urban-type settlements (PGT);

the prevalence in the structure of crime in the severity of acts of moderate severity and serious crimes;

maintaining a high level of crimes against human life and health, with a downward trend prevailing;

a significant predominance of crimes against property among all crimes with fluctuations in the indicators of the most common types of crime;

the tendency to reduce crime groups without a victim, the number of which depends on the activity of the police units in their detection during the majority of the period under review;

high crime against public safety;

the increase in the number of crimes, the proceedings of which is directed to the court committed by repeat offenders.

The general conclusion is that in Ukraine the process of transforming the criminality of a socialist society into the criminality of a market society is continuing, with the determining influence on the criminal situation of the dynamics of acquisitive crimes.

Keywords: criminal situation, crime, crime structure, crime dynamics, types of crime, crime rates, crime factors.

Отримано 06.06.2019

DOI (Article): https://doi.org/10.36486/np.2019.2.15

(C) Kulyk Oleksandr, 2019

Issue 2(4.4) 2019

http://naukaipravoohorona.com/ 


\author{
Мартиненко Олег Анатолійович, \\ доктор юридичних наук, професор \\ провідний науковий співробітник \\ ДНДІ МВС України, м. Київ, Україна \\ ORCID ID 0000-0003-0468-051X
}

\title{
РОБОТА ПОЛІЦІї В УМОВАХ ДЕОКУПАЦЇ: ЗАРУБІЖНИЙ ДОСВІД ТА КРИМІНОГЕННІ ВИКЛИКИ
}

У статті проаналізовано основні підходи, здійснені Хорватією, Боснією та Герчеговиною для налагодження ефективної діяльності полічї після завершення збройного конфлікту. Встановлено, що постконфліктні країни мають спільні підходи: демілітаризачія та реформування поліщії, навчання персоналу та його сертифікація, протидія корупџї та незаконному обігу зброї. Розглянуто зміст та особливості таких заходів, а також сутність криміногенних викликів, що постають перед полічією в умовах роботи на деокупованих територіях. Визначено, що досвід країн колишньої Югославї може бути врахований при стратегічному плануванні розвитку МВС України.

Ключові слова: діяльність полічії на деокупованих територіях, постконфліктний період, криміногенні виклики, демілітаризація та реформування поліції.

Перспективи завершення збройного конфлікту на Донбасі є одним із пріоритетних питань не лише політичних, а й наукових дискусій. У політичній сфері ці перспективи окреслені ініціативою України щодо введення на територію ОРДЛО миротворчої місії, яка активно обговорювалася у нормандському та мінському форматі упродовж 2018 року [1, 2]. У науковій, зокрема правовій, площині зазначена ініціатива, підтримана положеннями Закону України “Про особливості державної політики із забезпечення державного суверенітету України на тимчасово окупованих територіях у Донецькій та Луганській областях", а також практично-орієнтованою візією МВС України “Стратегія відновлення цілісності України і деокупації Донбасу. Механізм “малих кроків””.

Водночас у наукових колах практично не розглядаються прогностичні варіанти того, як саме може працювати поліція на деокупованих територіях, зважаючи на присутність міжнародних спостережних інституцій та нові криміногенні виклики. Мета нашої статті - окреслити основні проблеми, які можуть постати перед Національною поліцією та МВС України, враховуючи досвід постконфліктної діяльності поліції Хорватії, Боснії та Герцеговини.

Частково проблеми діяльності правоохоронних структур України в умовах деокупації та присутності миротворчої місії висвітлені у дослідженні О.В. Кресіна, I.M. Проценко, К.О. Савчука, О.М. Стойко [3]. Проте вони здебільшого стосувалися юрисдикції ДПСУ, митних та податкових органів, оскільки акцент у роботі зроблено на участь миротворчої місії в цивільних та господарських правовідносинах, екстратериторіальному статусі їі приміщень, переміщенні збройного

DOI (Article): https://doi.org/10.36486/np.2019.2.16

(c) Martynenko Oleh, 2019 
контингенту та техніки через державний кордон, непідлеглості миротворців юрисдикції України, а також на їх привілеях та імунітетах.

Якщо ж звернутися до особливостей роботи поліції Хорватії, Боснії та Герцеговини у постконфліктний період, то ми можемо помітити, що проблеми, які вирішували правоохоронці цих країн, можуть мати безпосередні аналоги із можливим розвитком подій в Україні: демілітаризація та реформування поліції, навчання персоналу та його сертифікація, протидія корупції та незаконному обігу зброї.

Передусім слід звернути увагу на специфіку Хорватії, де на території Східної Славонії, населеної переважно сербським населенням, після завершення війни залишилися сербські військові та поліцейські підрозділи. Оскільки вони не брали активної участі у військових діях 1991-1992 pр., хорватський уряд просто розформував ці підрозділи, не притягаючи сербських військових та поліцейських до кримінальної відповідальності. Проте хорватські органи влади не змогли запровадити на території Східної Славонії поліцейську службу, сформовану хорватським персоналом. Сербське населення регіону негативно ставилося до хорватських правоохоронців і було переконане, що хорватські поліцейські будуть виконувати свої обов’язки вкрай упереджено, керуючись мотивами помсти та дискримінації на етнічно-релігійному грунті.

Враховуючи напруженість постконфліктної ситуації, місія OOH (UNTAES) була вимушена запропонувати виключно для Східної Славонії т.зв. перехідні поліцейські сили - багатонаціональну поліцію (ТАРF).

Остання була створена за підтримки хорватських державних інституцій та місцевої сербської влади і складалася з 811 сербських, 815 хорватських офіцерів поліції та 52 представників інших етнічних груп. Для уникнення суб'єктивізму та можливих конфліктів до багатонаціональної поліції не були прийняті хорватські поліцейські, чиї родичі загинули під час війни, а також ті, чиї родичі проживали на той час у Сербії, Боснії, Чорногорії, Македонії. Одночасно не прийняли сербських поліцейських, стосовно яких були підозри у причетності до вчинення воєнних злочинів. 3 цих же міркувань, а також для забезпечення об'єктивності та неупередженості, до патрульних нарядів входили один сербський поліцейський, один хорватський та представник Цивільної поліції ООН [4].

Досить схожа ситуація може скластися в Україні, якщо контроль над ОРДЛО буде здійснювати тимчасова адміністрація ООН або миротворча місія, яка керуватиметься інтересами усіх сторін, ураховуючи, зокрема, положення Резолюції № 690 (1979) Парламентської асамблеї Ради Свропи “Декларація про поліцію”. Остання у розділі “С. Війна й інші надзвичайні обставини - окупація іноземною державою” констатує, що якщо “...поліцейський йде у відставку в період ворожої окупації у зв'язку з тим, що він примушується до виконання незаконних розпоряджень, що суперечать інтересам цивільного населення, як було описано вище, а також тому, що він не знаходить для себе іншого виходу, відразу після закінчення окупації його мають поновити на посаді поліцейського без шкоди особистих прав і доходів, які надавалися б йому, якби він залишався в поліції. На практиці це може означати, що Національна поліція України після завершення деокупації може бути вимушена розглядати питання поновлення на службі тих працівників

DOI (Article): https://doi.org/10.36486/np.2019.2.16

(C) Martynenko Oleh, 2019 
ОВС України, які залишилися на окупованих територіях і не вчиняли дій, що містять склад злочину.

Процес демілітаризації, незначний за масштабами в Хорватії, білыше стосувався Боснії та Герцеговини, де поліція під час війни стала надмірно мілітаризованою і майже не відрізнялася за формою та тактикою дій від військових підрозділів. Боснійські поліцейські описувалися як "солдати з поліцейськими шевронами, одягнені у військову форму або фактично організовані як воєнізовані підрозділи”. Поліцейські підрозділи брали безпосередню участь у бойових діях, та відповідно - мали відношення до вчинених воєнних злочинів [5]. До того ж, за оцінками ООН, під час війни 70 відсотків порушень прав людини в Боснії та Герцеговині можуть бути пов'язані з поліцією”, оскільки частина збройних поліцейських формувань майже не відрізнялась від організованої злочинності, займаючись грабежами, викраденням людей та контрабандою [6].

Перша стадія демілітаризації поліції передбачала, що у підрозділах залишається лише 1 гвинтівка (автомат) на 10 поліцейських та по одному пістолету на кожного поліцейського. 3 поліцейських підрозділів вилучили всі гранати, гранатомети, міни, кулемети тощо. "Спеціальна поліція” (аналог українських полків поліції спеціального призначення) була розформована, а загальну кількість поліцейських скоротили 344000 до 15800 станом на 2002 рік [7].

Друга стадія демілітаризації була тісно пов’язана з навчанням персоналу.

Після закінчення війни хорватські поліцейські, які проходили службу під час війни, пройшли обов'язкове додаткове навчання, 50 \% якого складала робота 3 населенням, діловий етикет та ділове листування, правила поліцейської роботи. МВС Хорватії відмовилося від підготовки поліцейських “фахівців на усі руки” і стало випускати виключно вузькоспеціалізованих поліцейських. Це дозволило частково вирішити проблему зниження політичного впливу на поліцію, коли офіцери могли просуватися політиками на посади незалежно від своєї спеціалізації. Навчання боснійських поліцейських 3 наступною сертифікацією передбачало складання іспитів із шести обов'язкових дисциплін, таких як: права людини, демократична робота поліції, правила дорожнього руху, основи управління, комп'ютерна підготовка, правоохоронна діяльність із залученням громадськості [8].

Серед криміногенних викликів найбільшою проблемою в діяльності поліції на деокупованих територіях залишається наявність нелегальної зброї. Після п'яти років після припинення бойових дій, у 2000 р., боснійська влада спільно з миротворчими силами вилучила 845 гвинтівок і пістолетів, більше 235000 патронів, 2614 ручних гранат, 1405 кг вибухових речовин і 5720 боєприпасів до мінометів і гранатометів. За 2003-2006 рр. під час добровільної здачі зброї від населення Боснії та Герцеговини (3 млн 503 тис. осіб) було отримано 15150 гвинтівок та пістолетів, більше 4780000 патронів, 54469 ручних гранат, 1200 кг вибухових речовин, 6476 мін, 58990 боєприпасів до мінометів та гранатометів.

Відповідно до дослідження, опублікованого ПРООН у 2004 р., кількість незареєстрованої стрілецької зброї коливалося у межах від 148400 до 494300 одиниць. Водночас у 2004 р. боснійськими правоохоронцями було офіційно зареєстровано 353000 одиниць цивільної вогнепальної зброї. Таким чином, у Боснії та Герцеговині на кожного четвертого мешканця припадало по одній одиниці

DOI (Article): https://doi.org/10.36486/np.2019.2.16

(c) Martynenko Oleh, 2019 
вогнепальної зброї - легальної або нелегальної [9]. Саме з цих причин контрабанда зброї з Боснії та Герцеговини до європейських країн досі становить серйозну загрозу безпеці на Західних Балканах.

Серед інших криміногенних викликів, що постали перед хорватськими та боснійськими поліцейськими, можна назвати наявність територій без належного поліцейського контролю; проблеми з етнічною, релігійною, політичною нетерпимістю; наявність кримінальних авторитетів та колишніх “польових командирів”, різних за небезпечністю та величиною районів, що перебували під їх впливом; масштаби корупції.

Відповідно до окреслених викликів складався спектр найбільш поширених видів протиправних дій:

вбивства за політичними, етнічними, релігійними мотивами;

насильство над представниками політичних, етнічних, релігійних меншин; крадіжки майна із залишених мешканцями будинків;

злочини із застосуванням зброї;

помста;

позасудова розправа;

помилковий донос.

Обтяжуючими факторами поліцейської діяльності в постконфліктний період були проблеми, що виникали у взаємодії з різними цільовими аудиторіями. Так, у стосунках із представниками міжнародних організацій та миротворчих місій в якості таких проблем зазначалися різний рівень стандартів професійної діяльності; наявність мовного та ментального бар'єрів; взаємна підозра у некомпетентності. Робота 3 населенням деокупованих територій також виявила серед проблем наявність негативних стереотипів стосовно поліції; недовіру громадян щодо неупередженості правоохоронців; підвищену агресивність у спілкуванні з поліцією; залежність від пропаганди воєнного часу.

Таким чином, досвід Хорватії, Боснії та Герцеговини демонструє, що процес налагодження ефективної поліцейської діяльності у постконфліктний період має враховувати наявність специфічних проблем у двох стратегічних напрямах. Перший стосується сфери управління, в якій потребують свого вирішення питання демілітаризації та подальшого реформування поліції, навчання та сертифікації (переатестації) персоналу, протидії корупції та розвитку засад community policing. Другий напрям безпосередньо стосується специфічних проблем деокупованих територій, серед яких провідні місця посідають незаконний обіг зброї та боєприпасів, поширеність злочинів з мотивів помсти, крадіжок покинутого майна, високий рівень аномії та недовіри до представників влади. Враховуючи викладене, можна стверджувати, що більшість проблем, пов'язаних із деокупаційною діяльністю поліції, може бути спрогнозована та врахована під час стратегічного планування розвитку МВС України.

\section{СПИСОК ВИКОРИСТАНИХ ДЖЕРЕЛ}

1. Robert Serry. Blue helmets in Donbas? A phased and sequenced scenario to unlock the Minsk agreements and restore peace in Ukraine. - UPEACE Centre The Hague. 2018. 32 p. URL: http://www.upeace.nl/cp/uploads/downloadsnieuws/UPH-report-Blue-Helmets-in-Donbas-(2018).pdf (дата звернення: 07.05.2019).

DOI (Article): https://doi.org/10.36486/np.2019.2.16

(C) Martynenko Oleh, 2019 
2. Richard Gowan. Can the United Nations Unite Ukraine? - Hudson Institute, 2018. 37 p. URL: https://www.hudson.org/research/14128-can-the-united-nations-unite-ukraine (дата звернення: 07.05.2019).

3. Проценко I.M., Савчук К.О., Стойко О.М. Політико-правові засади миротворчої операції в Донбасі: світовий досвід для України: наукова записка / Кресін О.В. (кер. авт. кол., наук. ред.), Київ: Інститут держави і права ім. В.М. Корецького НАН України, 2018. 243 с.

4. Dr. Florian Bieber. Policing the Peace after Yugoslavia: Police Reform between External Imposition and Domestic Reform - University of Kent, UK. 2010. 21 p. URL: http://www3.grips.ac.jp/ $\sim$ pinc/data/10-07.pdf (дата звернення: 03.05.2019).

5. Vejnovic, Dusko and Velibor Lalic. "Community Policing in a Changing World: A Case Study of Bosnia and Herzegovina”. Police Practice and Research 6(4). 2005. Pp. 363-373. URL: https:// www.researchgate.net/publication/233002762_Community_Policing_in_a_Changing_World_A_Case_ Study_of_Bosnia_and_Herzegovina (дата звернення: 03.05.2019).

6. Ivkovic, Sanja Kutnjak and Tara O'Connor Shelley. "The Bosnian Police and Police Integrity: A Continuing Story.” European Journal of Criminology (2). 2005. Pp. 428-464. URL: https:// journals.sagepub.com/doi/10.1177/1477370805056057 (дата звернення: 04.05.2019).

7. Celador, Gemma Collantes. "Becoming 'European' through Police Reform: A Successful Strategy In Bosnia and Herzegovina?" Crime, Law and Social Change 51. 2009. Pp. 231-242. URL: https://hal.archives-ouvertes.fr/hal-00478397/document (дата звернення: 03.05.2019).

8. Padurariu, A. The Implementation of Police Reform in Bosnia and Herzegovina: Analysing UN and EU Efforts. Stability: International Journal of Security \& Development, 3(1): 4. 2014. Pp. 1-18, URL: http://dx.doi.org/10.5334/sta.db (дата звернення: 06.05.2019).

9. Erwin Kauer. Weapons Collection and Destruction Programmes in Bosnia and Herzegovina. URL: http://www.bundesheer.at/pdf_pool/publikationen/small_arms_weapons_collection_ destruction_e_kauer.pdf (дата звернення: 06.05.2019).

\section{REFERENCES}

1. Robert Serry (2018) "Blue helmets in Donbas? A phased and sequenced scenario to unlock the Minsk agreements and restore peace in Ukraine”. - UPEACE Centre The Hague, 32 p. URL: http://www.upeace.nl/cp/uploads/downloadsnieuws/UPH-report-Blue-Helmets-in-Donbas-(2018).pdf (date of application: 07.05.2019) [in English].

2. Richard Gowan (2018) "Can the United Nations Unite Ukraine?", Hudson Institute, 37 p. URL: https://www.hudson.org/research/14128-can-the-united-nations-unite-ukraine (date of application: 07.05.2019) [in English].

3. Protsenko I.M., Savchuk K.O., Stoyko O.M. (2018) Polityko-pravovi zasady myrotvorchoi operatsii v Donbasi: svitovyi dosvid dlia Ukrainy. "Political and legal principles of the peacekeeping operation in the Donbass: world experience for Ukraine: Scientific note", edit. O.V. Kresin, Kyiv: Institute of State and Law named after Koretsky V.M. of National Academy of Sciences of Ukraine, 243 p. [in Ukrainian].

4. Florian Bieber, Dr. (2010) "Policing the Peace after Yugoslavia: Police Reform between External Imposition and Domestic Reform", University of Kent, UK, 21 p. URL: http://www3.grips. ac.jp/ pinc/data/10-07.pdf (date of application: 03.05.2019) [in English].

5. Vejnovic, Dusko and Velibor Lalic. (2005) "Community Policing in a Changing World: A Case Study of Bosnia and Herzegovina”, Police Practice and Research 6(4). 363-373 pp. URL: https://www.researchgate.net/publication/233002762_Community_Policing_in_a_Changing World_A_Case_Study_of_Bosnia_and_Herzegovina (date of application: 03.05.2019) [in English].

$\overline{6}$. Ivkovic, Sanja Kutnjak and Tara O'Connor Shelley. (2005) "The Bosnian Police and Police Integrity: A Continuing Story", European Journal of Criminology (2). 428-464 pp. URL: https:// journals.sagepub.com/doi/10.1177/1477370805056057 (date of application: 04.05.2019) [in English].

7. Celador, Gemma Collantes. (2009)”Becoming ‘European’ through Police Reform: A Successful Strategy In Bosnia and Herzegovina?", Crime, Law and Social Change 51, 231-242 pp. URL: https://hal.archives-ouvertes.fr/hal-00478397/document (date of application: 03.05.2019) [in English].

DOI (Article): https://doi.org/10.36486/np.2019.2.16

(c) Martynenko Oleh, 2019 Issue 2(44) 2019 http://naukaipravoohorona.com/ 
8. Padurariu, A. (2014) "The Implementation of Police Reform in Bosnia and Herzegovina: Analysing UN and EU Efforts Stability", International Journal of Security \& Development, 3(1): 4, 1-18 pp, URL: http://dx.doi.org/10.5334/sta.db (date of application: 06.05.2019) [in English].

9. Erwin Kauer. "Weapons Collection and Destruction Programmes in Bosnia and Herzegovina", URL: http://www.bundesheer.at/pdf_pool/publikationen/small_arms_weapons_collection_ destruction_e_kauer.pdf (date of application: 06.05.2019) [in English].

UDC 351.749, 343.92

Martynenko Oleh, Doctor of Juridical Sciences, Professor, Leading Researcher, State Research Institute MIA Ukraine, Kyiv, Ukraine, ORCID ID 0000-0003-0468-051X

\section{POLICE WORK UNDER CONDITIONS OF DEOCUPATION: FOREIGN EXPERIENCE AND CRIMINOGENIC CHALLENGES}

The article analyzes the main approaches taken by Croatia, Bosnia and Herzegovina to establish effective police activity after the end of the armed conflict. It has been defined that post-conflict countries have common approaches: demilitarization and police reform, personnel training and certification, counteracting corruption and illicit arms trafficking. The content and features of such measures, the relationship between demilitarization of the police and its reform and personnel training are considered. The creation of the Multinational Police in Eastern Slavonia (TAPF) has been considered in detail. The emphasis was placed on the compulsory training of police officers serving during the war, which includes the work with the public, human rights, democratic policing.

The essence of criminogenic challenges facing the police in the conditions of work in the de-occupied territories is analyzed. It is stated that the presence of illegal weapons poses a special threat to public safety.

Among the most widespread crimes committed in the postwar period, has been reported the following: violence against representatives of political, ethnic, religious minorities; theft of property from abandoned houses; revenge, extrajudicial execution, false denunciation. The problems of communication with different target audiences have been identified as the aggravating factors in policing during the post-conflict period.

It has been determined that the experience of the countries of the former Yugoslavia can be taken into account in the strategic planning of the development of the Ministry of Internal Affairs of Ukraine.

Keywords: police activity in the de-occupied territories, post-conflict period, criminogenic challenges.

Отримано 06.06.2019

DOI (Article): https://doi.org/10.36486/np.2019.2.16

(C) Martynenko Oleh, 2019

Issue 2(44) 2019

http://naukaipravoohorona.com/ 


\section{Мисливий Володимир Андрійович,} доктор юридичних наук, професор, професор кафедри публічного права Національного технічного університету України

“КПІ ім. Ігоря Сікорського”, м. Київ, Україна

\section{ЗЛОЧИНИ ПРОТИ БЕЗПЕКИ ДОРОЖНЬОГО РУХУ І КРАЙНЯ НЕОБХІДНІСТЬ}

У статті розглянуто кримінально-правові питання взаємозв'язку злочинів проти безпеки дорожнього руху та експлуатації транспорту з крайньою необхідністю як обставиною, що виключає злочинність діяння. Досліджено розвиток законодавства щодо крайньої необхідності. Проаналізовано застосування положень крайньої необхідності в теорії кримінального права та судовій практиці щодо злочинів проти безпеки дорожнього руху. Розглянуто помилки щодо визначення стану крайньої необхідності у цих деліктах та надано пропозицї щодо їх запобігання.

Ключові слова: безпека дорожнього руху, кримінальна відповідальність, крайня необхідність.

Злочини проти безпеки дорожнього руху та експлуатації транспорту залишаються одними з найбільш поширених діянь як у загальній структурі злочинності, так і серед злочинів, що вчиняються з необережності. При цьому найбільш аварійним залишається автомобільний транспорт, адже якщо за статистикою в дорожньо-транспортних пригодах у 60 -х роках XX століття щорічно гинуло близько 100 тис. людей [1, с. 16], то в 20-х роках XXI століття цей показник сягнув понад 1 млн 300 тис. чоловік. В Україні у структурі злочинності зазначені діяння упродовж останніх років стабільно займають четверту позицію (6 \%) після злочинів проти власності (54 \%), незаконного обігу наркотиків (12 \%) та злочинів проти життя і здоров'я особи (10\%) [2, с. 209].

Отже, протидія злочинам у сфері дорожнього руху та їх запобігання значною мірою впливають на охорону життя та здоров'я особи, власності та інших прав і свобод, задекларованих Конституцією України, законами та міжнародно-правовими актами. Реалізації цих положень має слугувати чимало чинників, серед яких: досконалість кримінального законодавства; рівень правової освіти, компетентності та професійної підготовки працівників правоохоронних органів та суду; якість методик розслідування та експертних методик щодо вказаних злочинів; належний рівень та узагальнення слідчої, прокурорської, експертної та судової практик стосовно дорожньо-транспортних деліктів та інші чинники.

Безумовно, що похідними серед них залишаються кримінально-правові засади безпеки дорожнього руху та експлуатації транспорту, які розробляли такі вітчизняні вчені, як С.В. Бабанін, В.І. Борисов, В.І. Василенко, С.В. Гизимчук, В.С. Гуславський, В.А. Звіряка, В.В. Смельяненко, В.І. Касинюк, З.Г. Корчева,

DOI (Article): https://doi.org/10.36486/np.2019.2.17

(c) Myslyvyi Volodymyr, 2019 
Я.В. Матвійчук, В.А. Мисливий, О.М. Опальченко, В.І. Осадчий, К.О. Полтава та інші фахівці, аналіз наукових праць яких дозволяє визначити загальні підходи до цієї проблеми. Водночас завжди існує потреба поглиблення кримінальноправових досліджень дорожньо-транспортних деліктів у межах їх взаємозв’язку 3 різними інститутами кримінального законодавства, зокрема, з крайньою необхідністю, яка слугує запобіганню помилковим рішенням при реалізації заходів кримінальної відповідальності.

Отже, метою цієї статті є розгляд кримінально-правових питань застосування крайньої необхідності як обставини, що виключає злочинність діяння у деліктах, пов’язаних із порушенням правил дорожнього руху та експлуатації транспорту.

Крайня необхідність як обставина, що виключає злочинність діяння, пройшла у кримінальному праві тривалий історичний розвиток, починаючи 3 приписів, що передбачали за певних умов виключення відповідальності за заподіяння шкоди особі або власності до її самостійного виокремлення як норми з аналогічною назвою.

За радянської доби Кримінальний кодекс України 1922 р. передбачав, що “не підлягає покаранню кримінально каране діяння, вчинене для врятування життя, здоров’я свого або іншої особи від небезпеки, яка була невідворотною за даних обставин іншими засобами, якщо заподіяна при цьому шкода є менш важливою у порівнянні із збереженим благом" [3, с. 12]. Пізніше ч. 2 ст. 13 КК УРСР 1927 р. майже продублювала це положення: “Заходи соціального захисту не застосовуються, якщо дії, передбачені в Кримінальному кодексі, було вчинено, щоб запобігти небезпеці, яку не можна було відвернути при даних обставинах іншими способами, коли зроблена через це шкода є менш важлива проти відвернутої шкоди” [4, с. 8].

КК Української РСР 1960 р. запропонував більш розвернуте поняття крайньої необхідності, а саме: "Не є злочином дія, яка хоч і підпадає під ознаки діяння, передбаченого кримінальним законом, але вчинена в стані крайньої необхідності, тобто для усунення небезпеки, що загрожує інтересам держави, громадським інтересам, особі чи правам цієї людини або інших громадян, якщо цю небезпеку за даних обставин не можна було усунути іншими засобами і якщо заподіяна шкода є менше значною, ніж відвернута шкода" (ст. 16 КК). Водночас зазначене визначення проти інших обставин, що виключають злочинність діяння (необхідна оборона, затримання злочинця), було не повним та не задовольняло практику.

Нарешті чинний Кримінальний кодекс України у ст. 39 "Крайня необхідність” передбачив її визначення у такій редакції:

“1. Не є злочином заподіяння шкоди правоохоронюваним інтересам у стані крайньої необхідності, тобто для усунення небезпеки, що безпосередньо загрожує особі чи охоронюваним законом правам цієї людини або інших осіб, а також суспільним інтересам чи інтересам держави, якщо цю небезпеку в даній обстановці не можна було усунути іншими засобами і якщо при цьому не було допущено перевищення меж крайньої необхідності.

2. Перевищенням меж крайньої необхідності є умисне заподіяння шкоди правоохоронюваним інтересам, якщо така шкода є більш значною, ніж відвернена шкода.

DOI (Article): https://doi.org/10.36486/np.2019.2.17

(C) Myslyvyi Volodymyr, 2019 
3. Особа не підлягає кримінальній відповідальності за перевищення меж крайньої необхідності, якщо внаслідок сильного душевного хвилювання, викликаного небезпекою, що загрожувала, вона не могла оцінити відповідність заподіяної шкоди цій небезпеці”.

Отже, новелою цієї норми стало більш системне та повне викладення змісту цієї обставини $з$ визначенням кримінальної відповідальності за перевищення меж крайньої необхідності, а також характеристикою можливого суб'єктивного стану особи, викликаного небезпекою, що загрожувала.

Стан крайньої необхідності визнається також у випадках, якщо дії, вчинені з метою відвернення шкоди, не досягли своєї мети і шкода настала, незважаючи на зусилля особи, яка сумлінно розраховувала її відвернути.

Аналіз наведених норм показує, що крайня необхідність розглядається як зіткнення декількох інтересів, що охороняються законом, і захист одного інтересу досягається шляхом заподіяння шкоди іншому. При цьому крайня необхідність серед інших обставин, що виключають злочинність діяння, залишається їх стабільною складовою. В історико-правовому аспекті вона характеризується різними прикладами, починаючи від знешкодження тварини, яка загрожувала життю людини, знищення майна для відвернення поширення пожежі до випадків канібалізму в умовах морського лиха тощо. У подальшому практика довела, що крайня необхідність знаходить застосування у захисті не лише особистих, а й суспільних та державних інтересів.

Наприкінці ХХ ст. особливу роль у цьому відіграє науково-технічний прогрес, під впливом якого постійно збільшується кількість “технічних" злочинів. Ускладнення техногенних процесів, поява об'єктів критичної інфраструктури, стрімке збільшення джерел підвищеної небезпеки та інших факторів все частіше породжують ситуації, пов'язані з виникненням небезпеки, що загрожує заподіянням суспільно небезпечних наслідків. Сфера дорожнього руху, в якій повсякденні порушення правил дорожнього руху та експлуатації транспорту є живильним джерелом створення небезпечних ситуацій, швидко знайшла своє місце як у теорії кримінального права, так і у практиці застосування кримінального законодавства. Більшість підручників, навчальних посібників, лекцій, у яких розглядаються питання крайньої необхідності, часто містять приклади, що показують застосування цієї обставини у сфері дорожнього руху.

При цьому слід визнати, що межі навчального процесу не завжди забезпечують достатній за обсягом розгляд окремих інститутів кримінального права, що не дозволяє грунтовно з'ясувати їх особливості, а тому майбутні юристи часто засвоюють відповідні положення на рівні наведених прикладів. Адже опорні знання, що грунтуються на типових прикладах, які легко запам'ятовуються, автоматично відтворюються при тлумаченні тих чи інших положень кримінального закону. Без упередження можна стверджувати, що, пояснюючи положення крайньої необхідності, майбутні юристи вдаються переважно до прикладів запобігання шкоді, посилаючись на сферу дорожнього руху. Нерідко це приводить до формування спотвореного уявлення про крайню необхідність, оскільки типові приклади про запобігання зіткнення транспортних засобів або уникнення наїзду на пішохода, який раптово вибігає на проїзну частину, не мають жодного відношення до крайньої необхідності [5, с. $155 ; 6$, с. 68; 7, с. 236].

DOI (Article): https://doi.org/10.36486/np.2019.2.17

(C) Myslyvyi Volodymyr, 2019 
За рідкісним виключенням приклади щодо крайньої необхідності мають типовий зміст і відображають такий механізм дорожньо-транспортної пригоди. На шляху руху транспортного засобу раптово з'являється небезпека (перешкода), внаслідок чого водій вживає крайніх заходів для уникнення наслідків, пов'язаних із заподіянням шкоди здоров'ю або життю потерпілих [8, с. 226]. У цих та інших ситуаціях джерелом небезпеки, як правило, виступають дії водіїв, які, керуючи транспортними засобами, виїжджають на зустрічну смугу проїзної частини, або дії пішоходів чи велосипедистів та інших учасників дорожнього руху, які раптово ставлять іншого водія транспортного засобу, діючого цілком правомірно, до вживання необхідних дій для запобігання шкоді. Саме такі дії отримують оцінку з позицій інституту крайньої необхідності.

Так, М. визнаний винним у тому, що, рухаючись із пасажирами на легковому автомобілі, виїхав на лівий бік дороги, в результаті чого виникло зіткнення 3 вантажівкою, якою керував С. Внаслідок аварії одному з пасажирів були заподіяні тяжкі тілесні ушкодження. Але Верховний Суд дійшов до іншого висновку, зазначивши, що М. вів свою машину з дотриманням усіх правил дорожнього руху. Що ж до С., то він, грубо порушуючи правила, перебуваючи у нетверезому стані, рухався з лівого боку дороги на великій швидкості, у результаті чого створив для машини, якою керував М., загрозу лобового зіткнення і змусив М., коли відстань між машинами була не більше 20 м, зробити різкий маневр ліворуч. Дещо пізніше С. також повернув праворуч, у результаті чого відбулося зіткнення транспортних засобів.

У провадженні встановлено, що, з огляду на особливості дороги, М. не міг здійснити поворот праворуч, а якби він зупинив автомашину, загроза лобового удару не зникла б. Пленум Верховного Суду визнав, що М. у цій конкретній обстановці прийняв єдине правильне рішення - щоб уникнути лобового зіткнення, він здійснив поворот ліворуч, чим відвернув більш тяжкі наслідки. На підставі викладеного Пленум визнав, що в діях М. відсутній склад злочину, оскільки він діяв у стані крайньої необхідності [9, с. 390].

Вважаємо, що як теорія кримінального права, так і практика не дають обгрунтованих підстав для подібної оцінки дій і вимагають обачливого й критичного ставлення до такого трактування крайньої необхідності. Насправді, аналіз дорожньотранспортної ситуації у наведеному судовому прецеденті свідчить про те, що водій С. внаслідок своїх протиправних дій (виїзд на зустрічну смугу руху) створив небезпечну дорожню обстановку, яка створювала реальну загрозу здоров'ю та життю учасників дорожнього руху (водіям і пасажирам вказаних автомашин) внаслідок можливого зіткнення транспортних засобів. Водій М., запобігаючи вказаним наслідкам, діяв відповідно до правил дорожнього руху, згідно з якими допускалося кілька варіантів поведінки: зниження швидкості, зупинка транспортного засобу або застосування безпечного маневру. Оскільки водій М. обгрунтовано розрахував, що перші два варіанти не гарантують безпеки дорожнього руху, він ужив заходів щодо використання останнього - безпечного маневру. Подальший розвиток ситуації показав, що такий маневр хоча і був виправданим, але не забезпечив запобігання настанню суспільно небезпечних наслідків. Адже заподіяння шкоди стало наслідком триваючого порушення правил дорожнього

DOI (Article): https://doi.org/10.36486/np.2019.2.17

(C) Myslyvyi Volodymyr, 2019 Issue 2(44) 2019 http://naukaipravoohorona.com/ 
руху водієм С., який шляхом маневру на праву смугу проїзної частини перетворив небезпечну дорожню обстановку в аварійну.

Водночас розвиток механізму дорожньо-транспортної пригоди показує, що водій М., уникаючи зіткнення транспортних засобів і запобігаючи настанню суспільно небезпечних наслідків, зовсім не розраховував на заподіяння будь-якої меншої шкоди. Звільняючи смугу руху водію-правопорушнику, він взагалі прагнув уникнути будь-якої шкоди для учасників дорожнього руху.

Оскільки поведінка М. у процесі дорожнього руху повністю відповідала вимогам його безпеки, у цьому випадку нема підстав для кримінально-правового аналізу його дій з позицій крайньої необхідності. Іншими словами, в цій ситуації взагалі йдеться про відсутність стану крайньої необхідності.

Що стосується водія С., то його дії, пов’язані з порушенням правил безпеки дорожнього руху, утворюють склад злочину, передбачений ч. 2 ст. 215 КК України (1960), у зв'язку з чим він має нести кримінальну відповідальність.

Наведемо ще більш невдалий приклад із судової практики, який кілька десятиліть переходить із підручника в підручник. Водій К., засуджений за злочин, пов’язаний з порушенням правил безпеки дорожнього руху, вчинений за таких обставин. Керуючи транспортним засобом, К. рухався на машині правою стороною проїзної частини, не порушуючи правил дорожнього руху. Біля автобусної зупинки на дорогу раптово вибіг громадянин Р. Наїзд на нього був неминучим. Щоб запобігти цьому К. різко звернув ліворуч. У цю ж мить мотоцикл, що рухався назустріч, зіткнувся з машиною. При цьому пасажир мотоцикла Т. отримав тілесні ушкодження. Свідки підтвердили, що К. був вимушений вчинити поворот ліворуч, щоб уникнути наїзду на Р. Враховуючи ці обставини, суд помилково визнав, що К. діяв у стані крайньої необхідності (курсив наш - B. A.), вжив заходи, щоб не наїхати на Р., а тому в його діях немає складу злочину [10, с. 19-20].

Водночас необхідно завжди враховувати, що поводження особи у стані крайньої необхідності завжди є усвідомленим, оскільки вона в тій чи іншій ситуації оцінює обстановку, вибирає засоби, приймає рішення тощо. Що ж стосується поведінки водія у вказаному вище випадку, то він діяв в аварійній обстановці, тобто в такій обстановці, в якій він не мав технічної можливості запобігти наслідкам. В аварійній ситуації поведінка водія має підсвідомий, рефлекторний характер, що не дає підстав для її правової оцінки, а тому така поведінка із зовнішнього боку, хоча і спрямована на запобігання суспільно небезпечним наслідкам, вона не має нічого спільного з крайньою необхідністю.

У цьому судовому прецеденті йдеться про створення аварійної обстановки для водія К., адже навіть висновком суду чітко наголошено, що наїзд на пішохода був неминучим. Зважаючи на слідчу та судову практику щодо вказаних деліктів, це означає, що в цій конкретній ситуації водій К. не мав технічної можливості запобігти наїзду на пішохода шляхом розрахованих дій із виконання вимог правил безпеки дорожнього руху, а тому в цьому разі відсутній як стан крайньої необхідності, так і ознаки складу злочину, передбаченого ст. 286 КК України.

Звичайно, виникає питання, хто ж підлягає відповідальності за заподіяння шкоди потерпілому Т. Згідно з чинним законодавством таку відповідальність

DOI (Article): https://doi.org/10.36486/np.2019.2.17

(c) Myslyvyi Volodymyr, 2019 
повинен нести за ст. 291 КК України пішохід Р., який створив на дорозі аварійну обстановку.

На жаль, у деяких наукових виданнях також розглядаються необгрунтовані тлумачення крайньої необхідності стосовно сфери дорожнього руху. Так, В.Б. Малінін вважає, що раптова поява пішохода на проїзній частині поза пішохідним переходом примушує водіїв порушувати Правила дорожнього руху (виїзд на смугу зустрічного руху, різка зміна швидкості руху, виїзд на пішохідну доріжку тощо). Ці дії, помилково констатує він, викликаються крайньою необхідністю і часто призводять до тяжких наслідків [11, с. 293].

Характерно, що певним суперечностям у цьому іноді сприяють рекомендації вищих судових інстанцій. Зокрема, у п. 7 постанови Пленуму Верховного Суду України "Про практику застосування судами України законодавства у справах про деякі злочини проти безпеки дорожнього руху та експлуатації транспорту, а також про адміністративні правопорушення на транспорті” міститься таке положення: "У випадках, коли передбачені ст. 286 КК суспільно небезпечні наслідки настали через порушення правил безпеки дорожнього руху або експлуатації транспорту двома або більше водіями транспортних засобів, суди повинні з'ясовувати характер порушень, які допустив кожен із них, а також, чи не було причиною порушення зазначених правил одним водієм їх недодержання іншим і чи мав перший можливість уникнути дорожньо-транспортної події та її наслідків. При цьому слід мати на увазі, що за певних умов виключається кримінальна відповідальність особи, яка порушила правила дорожнього руху вимушено, через створення аварійної ситуацій (курсив наш - B. М.) іншою особою, котра керувала транспортним засобом” [12, с. 251-252].

Такі рекомендації взагалі не враховують особливостей об'єктивної сторони порушень правил безпеки дорожнього руху та експлуатації транспорту. Адже, поперше, необгрунтованим є використання терміна “ситуащія", який у теорії кримінального права не є визнаним. Натомість замість терміна “ситуація” необхідно розглядати таку ознаку об’єктивної сторони, як “аварійну обстановку”. По-друге, конструкція “особа порушила правила дорожнього руху вимушено” у цьому контексті є неприйнятною. Теорією кримінального права, експертною і судовою практиками щодо цих злочинів поняття “аварійна обстановка” розглядається у тих випадках, коли водій не має технічної можливості запобігти настанню наслідків, оскільки, опинившись у такій обстановці, він позбавлений можливості діяти усвідомлено, внаслідок чого його поведінка має автоматичний, рефлекторний характер, а тому не підлягає правовій оцінці. Відтак діяти “вимушено” означає виконувати щось проти бажання, потреби, під тиском обставин, що, на нашу думку, хоча й виглядає синонімічно, проте зовсім не еквівалентно підсвідомій поведінці. Адже, якщо особа діє вимушено, це не означає позбавлення ії̈ поведінки усвідомленого та вольового характеру, яка може бути оцінена як протиправна, тобто така, що не виключає кримінальної відповідальності. Отже, Верховний Суд має використовувати у своїх роз'ясненнях чітко визначені правові та інші категорії, які не повинні викликати довільних тлумачень при їх застосуванні.

На наше переконання, приклади та рекомендації щодо крайньої необхідності у сфері безпеки дорожнього руху мають бути такими, що дійсно містять ознаки цього інституту. Наведемо один із таких прикладів. Водій легкового автомобіля приватної установи побачив, що самоскид, залишений на узбіччі, почав рухатись у напрямку зупинки транспорту загального користування, що загрожувало наїздом на громадян, які чекали рейсового автобуса. У цій ситуації водій легкового авто-

DOI (Article): https://doi.org/10.36486/np.2019.2.17

(C) Myslyvyi Volodymyr, 2019 
мобіля, розуміючи, що відвернути небезпеку, яка виникла, можливо лише негайною зупинкою вантажівки, свідомо спрямував свій автомобіль у бік самоскида та припинив його подальший рух. Таким чином, небезпеку, що безпосередньо загрожувала життю людей, було усунуто шляхом заподіяння меншої шкоди - пошкодженням легкового автомобіля. Цей та подібні приклади дійсно ілюструють інститут крайньої необхідності у сфері безпеки дорожнього руху.

Очевидно, з метою уникнення суперечливих оцінок та помилок працівників правоохоронних органів та суду при аналізі крайньої необхідності у сфері дорожнього руху необхідно внести відповідні доповнення до зазначеної вище постанови Пленуму Верховного Суду України, що стосуються оцінки дій водія в аварійній обстановці.

Зазначені положення можна сформулювати так: “Дії водія не утворюють злочинного порушення правил безпеки дорожнього руху або експлуатації транспорту, якщо заподіяння шкоди правоохоронюваним інтересам було вчинене у стані крайньої необхідності, тобто внаслідок небезпеки, створеної учасниками дорожнього руху або іншими особами, що безпосередньо загрожувала здоров'ю, життю громадян або іншим охоронюваним законом суспільним інтересам, яку не можна було усунути іншими засобами, і при цьому не було допущено перевищення меж крайньої необхідності. При цьому відвернення небезпеки шляхом заподіяння меншої шкоди повинно бути результатом усвідомленого вибору тої чи іншої поведінки водієм транспортного засобу. Якщо такі дії вчинені водієм в аварійній ситуації, вони не повинні розглядатися щодо їх відповідності правилам дорожнього руху та не підлягають правовій оцінці з позицій стану крайньої необхідності”.

\section{СПИСОК ВИКОРИСТАНИХ ДЖЕРЕЛ}

1. Норман Л.Г. Несчастные случаи на дорожном транспорте. Эпидемиология. Меры борьбы и профилактика. ВОЗ. Женева. 1962. 152 с.

2. Бесчастний В. Кримінологічний аналіз стану злочинності в Україні. Підприємництво, господарство і право. 2017. № 1. С. 207-213. 1922. $75 \mathrm{c}$

3. Уголовный кодекс У.С.С.Р. Харьков: Юридическое издательство Наркомюста УССР,

4. Уголовный кодекс У.С.С.Р. В ред. 1927 г. Харьков: Юридическое издательство Наркомюста УССР, 1928. 129 с.

5. Советское уголовное право. Общая часть: учеб. / под ред. Г.А. Кригера, Н.Ф. Кузнецовой, Ю.М. Ткачевского. М.: Изд-во МГУ, 1988. 368 с.

6. Бажанов М.И. Уголовное право Украины. Общая часть: учеб. пособие. Днепропетровск: Пороги, 1992. С. 68.

7. Александров Ю.В., Антипов А.І. та ін. Кримінальне право України. Загальна частина: підручник / за ред. М.І Мельника, В.А. Клименка. 5-те вид., переробл. та допов. К.: Атіка, 2009. $408 \mathrm{c.}$

8. Андрусів Г.В., Андрушко П.П., Бенківський В.В. та ін. Кримінальне право України. Загальна частина: підручник для студ. юрид. вузів і факультетів / за ред. П.С. Матишевського та ін. К.: Юрінком Інтер, 1997. 512 с. 516 c.

9. Пионтковский А.А. Курс советского уголовного права: в 6 т. М.: Наука, 1970. Т. 2.

10. Практика прокурорского надзора при рассмотрении судами уголовных дел: сб. документов. М.: Юрид. лит., 1987. 672 с.

11. Малинин В.Б. Причинная связь в уголовном праве. СПб.: Изд-во "Юридический центр Пресс", 2000. 316 с.

12. Про практику застосування судами України законодавства у справах про деякі злочини проти безпеки дорожнього руху та експлуатації транспорту, а також про адміністративні правопорушення на транспорті: постанова Пленуму Верховного Суду України від 23.12.2005 № 14. URL: https://zakon.rada.gov.ua/laws/show/v0014700-05 (дата звернення: 15.04.2019).

DOI (Article): https://doi.org/10.36486/np.2019.2.17

(C) Myslyvyi Volodymyr, 2019 Issue 2(44) 2019 http://naukaipravoohorona.com/ 


\section{REFERENCES}

1. Norman L.G. (1952). Neschastnyye sluchai na dorozhnom transportye. Epidyemiologiya. Mery borby i profilaktika. "Road traffic accidents. Epidemiology. Control measures and prevention". WOZ. Geneva. 152 p. [in Russian].

2. Beschastnyi V. (2017). Kryminolohichnyi analiz stanu zlochynnosti v Ukraini. Pidpryiemnytstvo, hospodarstvo i pravo. "Criminological analysis of crime in Ukraine. Entrepreneurship, economy and law". No. 1. P. 207-213 [in Ukrainian].

3.Ugolovnyy kodeks U.S.S.R. "The Criminal Code of the US.S.R". Kharkov: Legal Publishing House of the People's Commissariat of the Ukrainian SSR, 1922. 75 p. [in Russian].

4. Ugolovnyy kodeks U.S.S.R. v red. 1927 g. "The Criminal Code of the US.S.R. as amended 1927”. Kharkov: Legal Publishing House of the People's Commissariat of the Ukrainian SSR, 1928. 129 p. [in Russian].

5. Sovetskoye ugolovnoye pravo. Obshchaya chast: ucheb. "Soviet criminal law. General part: textbook”. / ed. G.A. Krieger, N.F. Kuznetsova, Yu.M. Tkachevsky. M.: Publishing house of Moscow State University, 1988.368 p. [in Russian].

6. Bazhanov M.I. (1992). Ugolovnoye pravo Ukrainy. Obshchaya chast: ucheb. posobiye. "Criminal law of Ukraine". General part: textbook. allowance. Dnepropetrovsk: Thresholds. 68 p. [in Russian].

7. Aleksandrov Yu.V., Antypov A.I. ta in. (2009). Kryminalne pravo Ukrainy. Zahalna chastyna: pidruchnyk. "Criminal law of Ukraine". The general part: the textbook. in a row. MI Melnyk,

V.A Klimenko. 5 species, reworked. and extra. K.: Attica. 408 p. [in Ukrainian].

8. Andrusiv H.V., Andrushko P.P., Benkivskyi V.V. ta in. (1997). Kryminalne pravo Ukrainy. Zahalna chastyna: pidruchnyk dlia stud. yuryd. vuziv i fakultetiv. "Criminal law of Ukraine". The common part: a textbook for students of Juridical universities and faculties edited by P.S. Matyshevskyi et al. K.: Jurinkom Inter. 512 p. [in Ukrainian].

9. Piontkouskiy A.A. (1970). Kurs sovetskogo ugolovnogo prava: v 6 t. "The course of Soviet criminal law": in 6 vols. M.: Nauka. Vol.2. 516 p. [in Russian].

10.Praktika prokurorskogo nadzora pri rassmotrenii sudami ugolovnykh del: sb. dokumentov. "The practice of prosecutorial supervision in the consideration of criminal cases by courts": Sat. documents. M.: Jurid. liter., 1987. 672 p. [in Russian].

11. Malinin V.B. (2000). Prichinnaya svyaz v ugolovnom prave. "Causation in criminal law". SPb.: Publishing House "Legal Center Press". 316 p. [in Russuian].

12. Pro praktyku zastosuvannya sudamy Ukrayiny zakonodavstva u spravakh pro deiaki zlochyny proty bezpeky dorozhn№oho rukhu ta ekspluatatsiyi transportu, a takozh pro administratyvni pravoporushennya na transporti. "On the practice of application by the courts of Ukraine of legislation on cases of certain crimes against road safety and operation of transport, as well as on administrative offenses in transport": resolution of the Plenum of the Supreme Court of Ukraine dated 23.12.2005 No. 14. URL: https: //zakon.rada gov.ua / laws / show / v0014700-05 (date of application: 15.04.2019) [in Ukrainian].

UDC 343.346

Myslyvyi Volodymyr, Doctor of Juridical Sciences, Professor, Professor of the Public Law Department of the National Technical University of Ukraine "The Igor Sikorsky Kyiv Polytechnic Institute", Kyiv, Ukraine

\section{ROAD SAFETY CRIMES AND EXTREME NECESSITY}

The article deals with criminal and legal questions of interrelation between crimes in the sphere of road traffic safety with extreme necessity as a circumstance excluding the crime of action. The author has noted that in Ukraine, criminal

DOI (Article): https://doi.org/10.36486/np.2019.2.17

(C) Myslyvyi Volodymyr, 2019 
violations of road safety are on the fourth position in the general structure of crime, therefore a substantiated legal assessment of these acts from the positions of the institute of extreme necessity is important.

In order to properly use extreme necessity as circumstances excluding criminal activity in road safety situations the author has studied the development of this institute in domestic legislation, in particular the criminal codes of 1922, 1927 and 1960, as well as the contents of extreme necessity in Art. 39 "Extreme necessity" of the current Criminal Code of Ukraine. The analysis shows that extreme necessity has always been considered as a collision of several interests protected by law, and the protection of one interest is achieved by causing harm to another. At the end of the 20 -th century the scientific and technological progress and in particular the field of traffic, in which everyday violations of road safety rules became a source of dangers requiring their consideration from the point of view of extreme necessity, play a special role in this.

In this regard the author has examined provisions of extreme necessity in the theory of criminal law and their application in judicial practice when considering road safety crimes, as well as doctrinal interpretation in scientific and educational publications. He has identified and considered mistakes in determining the state of extreme necessity in these offences associated with the formation of the distorted idea of extreme necessity as typical examples of preventing vehicles collisions or avoiding hitting pedestrians who suddenly find themselves in the traffic lane do not always make a state of extreme necessity.

It has been noted that a person behavior in a state of extreme necessity must always be realized since in one or another condition he/she assesses the situation, chooses the means and makes appropriate decisions to eliminate the harm. On this basis it is impossible to consider the driver's state in an emergency situation as being characterized by extreme necessity. In an emergency the driver's behavior while outwardly aimed at preventing socially dangerous consequences is not associated with extreme necessity, since it has subconscious, reflexive nature. Such behavior is not subject to legal assessment.

From the same positions the author has marked certain contradictions in the resolution of the Plenary Session of the Supreme Court of Ukraine "On the Practice of the Use by the Courts of Ukraine of Legislation on Cases Concerning Certain Road Safety and Vehicle Operation Crimes, and also on Vehicles Administrative Offenses" concerning the occurrence of socially dangerous consequences due to violation of road safety or vehicle operation rules by two or more drivers of vehicles in an emergency situation.

The author proposed appropriate amendments to the above-mentioned resolution in order to avoid conflicting assessments and mistakes by law enforcement and judicial authorities in the analysis of extreme necessity in the field of road traffic.

Keywords: road safety, criminal liability, extreme necessity.

Отримано: 06.06.2019

DOI (Article): https://doi.org/10.36486/np.2019.2.17

(C) Myslyvyi Volodymyr, 2019 
Музика Анатолій Ананійович, доктор юридичних наук, професор, член-кореспондент НАПрН України, заслужений діяч науки і техніки України, провідний науковий співробітник ДНДІ МВС України, м. Київ, Україна

\section{СПЕЦІАЛЬНА КОНФІСКАЦІЯ ЗА КРИМІНАЛЬНИМ КОДЕКСОМ УКРАЇНИ: НАУКОВО-ПРАКТИЧНИЙ КОМЕНТАР}

Стаття 96-1. Спеціальна конфіскація

1. Спеціальна конфіскація полягає у примусовому безоплатному вилученні за рішенням суду у власність держави грошей, цінностей та іншого майна у випадках, визначених цим Кодексом, за умови вчинення умисного злочину або суспільно небезпечного діяння, що підпадає під ознаки діяння, передбаченого Особливою частиною цього Кодексу, за які передбачено основне покарання у виді позбавлення волі або штрафу понад три тисячі неоподатковуваних мінімумів доходів громадян, а так само передбаченого частиною першою статті 150, статтею 154, частинами другою і третьою статті 159-1, частиною першою статті 190, статтею 192, частиною першою статей 204, 209-1, 210, частинами першою i другою статей 212, 212-1, частиною першою статей 222, 229, 239-1, 239-2, частиною другою статті 244, ча-стиною першою статей 248 , 249, частинами першою і другою статті 300, частиною першою статей $301,302,310,311,313,318,319,362$, статтею 363, частиною першою статей 363-1, 364-1, 365-2 цього Кодексу.

2. Спеціальна конфіскація застосовується на підставі:

1) обвинувального вироку суду;

2) ухвали суду про звільнення особи від кримінальної відповідальності;

3) ухвали суду про застосування примусових заходів медичного характеру;

4) ухвали суду про застосування примусових заходів виховного характеру.

3. У випадках, коли об'єктом спеціальної конфіскації є майно, вилучене з цивільного обороту, вона може бути застосована на підставі:

1) ухвали суду про закриття кримінального провадження з інших підстав, аніж звільнення особи від кримінальної відповідальності;

2) ухвали суду, постановленої в порядку частини дев'ятої статті 100 Кримінального процесуального кодексу України, за клопотанням слідчого чи прокурора, якщо кримінальне провадження закривається ними.

(Кодекс доповнено статтею 96-1 згідно із Законом № 222-VII від 18.04.2013; в редакиї Закону № 1261-VII від 13.05.2014; із змінами, внесеними заідно із Законом № 731-VIII від 08.10.2015; текст статті 96-1 в редакцї Закону № 770-VIII від 10.11.2015; із змінами, внесеними згідно із Законом № 743-VIII від 03.11.2015; текст статті 96-1 в редакції Закону № 1019-VIII від 18.02.2016)

1. Розділ XIV Загальної частини КК доповнений статтями 96-1 і 96-2 (про спеціальну конфіскацію) на підставі Закону “Про внесення змін до Кримінального

DOI (Article): https://doi.org/10.36486/np.2019.2.18

(c) Muzyka Anatolii, 2019 Issue 2(4.4) 2019 http://naukaipravoohorona.com/ 
та Кримінального процесуального кодексів України стосовно виконання Плану дій щодо лібералізації Європейським Союзом візового режиму для України” від 18 квітня 2013 р. № 222-VII, який набрав чинності 15 грудня 2013 р.

У подальшому положення щодо спеціальної конфіскації неодноразово корегувалися на підставі законів:

"Про внесення змін до деяких законодавчих актів України у сфері державної антикорупційної політики у зв'язку з виконанням Плану дій щодо лібералізації Європейським Союзом візового режиму для України” від 13 травня 2014 р. № 1261-VII;

“Про внесення змін до деяких законодавчих актів України щодо запобігання і протидії політичній корупції” від 8 жовтня 2015 р. № 731-VIII;

"Про запобігання впливу корупційних правопорушень на результати офіційних спортивних змагань” від 3 листопада 2015 р. № 743-VIII;

“Про внесення змін до Кримінального кодексу України щодо вдосконалення інституту спеціальної конфіскації з метою усунення корупційних ризиків при іï застосуванні” від 10 листопада 2015 р. № 770-VIII;

"Про внесення змін до Кримінального та Кримінального процесуального кодексів України щодо виконання рекомендацій, які містяться у шостій доповіді Європейської комісії про стан виконання Україною Плану дій щодо лібералізації Європейським Союзом візового режиму для України, стосовно удосконалення процедури арешту майна та інституту спеціальної конфіскації” від 18 лютого 2016 р. № 1019-VIII.

Під час застосування спеціальної конфіскації необхідно враховувати час її запровадження в КК, а також відповідні зміни і доповнення, яких зазнавала редакція статей 96-1, 96-2. Йдеться про зворотну дію кримінального закону у часі (ст. 5). На цьому акцентовано і в Прикінцевих положеннях Закону від 13 травня 2014 р. № 1261-VII: дія зазначеного Закону поширюється на злочини та суспільно небезпечні діяння, що підпадають під ознаки діяння, передбаченого Особливою частиною Кримінального кодексу України, які були вчинені після набрання чинності цим Законом; заходи кримінально-правового характеру, передбачені цим Законом, в тому числі зміни до статей 96-1, 96-2, не мають зворотної дії і не поширюються на злочини та суспільно небезпечні діяння, що підпадають під ознаки діяння, передбаченого Особливою частиною Кримінального кодексу України, вчинені до набрання чинності цим Законом.

Слід мати на увазі, що положення про спеціальну конфіскацію в санкціях норм Особливої частини КК України не згадуються, вони виключені на підставі Законів від 10 листопада 2015 р. № 770-VIII та від 18 лютого 2016 р. № 1019-VIII.

2. Коментована стаття містить визначення поняття спеціальної конфіскації. Ïї суть розкривається у законі через такі ознаки:

- вилучення у власність держави певних предметів;

- таке вилучення є примусовим і безоплатним;

- всі предмети, що підлягають вилученню - спеціальній конфіскації, охоплюються поняттям “майно” (гроші, цінності та інше майно);

- загальною підставою застосування спеціальної конфіскації є відповідне рішення суду (одне із чотирьох можливих, що передбачені у ч. 2 ст. 96-1), а саме

DOI (Article): https://doi.org/10.36486/np.2019.2.18

(C) Muzyka Anatolii, 2019 
наявність: 1) обвинувального вироку суду, або 2) ухвали суду про звільнення особи від кримінальної відповідальності, або 3) ухвали суду про застосування примусових заходів медичного характеру, або 4) ухвали суду про застосування примусових заходів виховного характеру;

- спеціальною підставою застосування спеціальної конфіскації (у випадках, коли об'єктом спеціальної конфіскації є майно, вилучене з цивільного обороту), визнається одне із двох можливих рішень суду: 1) ухвала суду про закриття кримінального провадження з інших підстав, аніж звільнення особи від кримінальної відповідальності, або 2) ухвала суду, постановленої в порядку ч. 9 ст. 100 КПК, за клопотанням слідчого чи прокурора, якщо кримінальне провадження закривається ними;

- альтернативною умовою застосування спеціальної конфіскації є вчинення: 1) умисного злочину, або 2) відповідного суспільно небезпечного діяння, що підпадає під ознаки діяння, передбаченого Особливою частиною КК України (в обох випадках до уваги береться санкція норми - основне покарання має бути у виді: позбавлення волі, незалежно від його строку, або штрафу понад три тисячі неоподатковуваних мінімумів доходів громадян - понад 51 тис. грн), або 3) одного із умисних злочинів, наведених у відповідному переліку посягань (ч. 1 ст. 96-1), або 4) суспільно небезпечного діяння, передбаченого зазначеним переліком. Це такі суспільно небезпечні діяння, як:

експлуатація дітей (ч. 1 ст. 150), примушування до вступу в статевий зв’язок (ст. 154), порушення порядку фінансування політичної партії, передвиборної агітації, агітації з всеукраїнського або місцевого референдуму (ч. 2 і 3 ст. 159-1), шахрайство (ч. 1 ст. 190), заподіяння майнової шкоди шляхом обману або зловживання довірою (ст. 192), незаконне виготовлення, зберігання, збут або транспортування з метою збуту підакцизних товарів (ч. 1 ст. 204), умисне порушення вимог законодавства про запобігання та протидію легалізації (відмиванню) доходів, одержаних злочинним шляхом, або фінансування тероризму (ч. 1 ст. 209-1), нецільове використання бюджетних коштів, здійснення видатків бюджету чи надання кредитів з бюджету без встановлених бюджетних призначень або з їх перевищенням (ч. 1 ст. 210), ухилення від сплати податків, зборів (обов’язкових платежів) ч. 1, 2 ст. 212, ухилення від сплати єдиного внеску на загальнообов’язкове державне соціальне страхування та страхових внесків на загальнообов'язкове державне пенсійне страхування (ч. 1, 2 ст. 212-1), шахрайство з фінансовими ресурсами (ч. 1 ст. 222), незаконне використання знака для товарів і послуг, фірмового найменування, кваліфікованого зазначення походження товару (ч. 1 ст. 229), незаконне заволодіння грунтовим покривом (поверхневим шаром) земель (ч. 1 ст. 239-1), незаконне заволодіння землями водного фонду в особливо великих розмірах (ч. 1 ст. 239-2), порушення законодавства про континентальний шельф України (ч. 2 ст. 244), незаконне полювання (ч. 1 ст. 248), незаконне зайняття рибним, звіриним або іншим водним добувним промислом (ч. 1 ст. 249), ввезення, виготовлення або розповсюдження творів, що пропагують культ насильства i жорстокості, расову, національну чи релігійну нетерпимість та дискримінацію (ч. 1, 2 ст. 300), ввезення, виготовлення, збут і розповсюдження порнографічних предметів (ч. 1 ст. 301), створення або утримання місць розпусти і звідництво

DOI (Article): https://doi.org/10.36486/np.2019.2.18

(C) Muzyka Anatolii, 2019 Issue 2(4.4) 2019 http://naukaipravoohorona.com/ 
(ч. 1 ст. 302), посів або вирощування снотворного маку чи конопель (ч. 1 ст. 310), незаконне виробництво, виготовлення, придбання, зберігання, перевезення чи пересилання прекурсорів (ч. 1 ст. 311), викрадення, привласнення, вимагання обладнання, призначеного для виготовлення наркотичних засобів, психотропних речовин або їх аналогів, чи заволодіння ним шляхом шахрайства або зловживання службовим становищем та інші незаконні дії з таким обладнанням (ч. 1 ст. 313), незаконне виготовлення, підроблення, використання чи збут підроблених документів на отримання наркотичних засобів, психотропних речовин або прекурсорів (ч. 1 ст. 318), незаконна видача рецепта на право придбання наркотичних засобів або психотропних речовин (ч. 1 ст. 319), несанкціоновані дії з інформацією, яка оброблюється в електронно-обчислювальних машинах (комп'ютерах), автоматизованих системах, комп'ютерних мережах або зберігається на носіях такої інформації, вчинені особою, яка має право доступу до неї (ч. 1 ст. 362), порушення правил експлуатації електронно-обчислювальних машин (комп'ютерів), автоматизованих систем, комп'ютерних мереж чи мереж електрозв’язку або порядку чи правил захисту інформації, яка в них оброблюється (ст. 363), перешкоджання роботі електронно-обчислювальних машин (комп'ютерів), автоматизованих систем, комп'ютерних мереж чи мереж електрозв’язку шляхом масового розповсюдження повідомлень електрозв'язку (ч. 1 ст. 363-1, зловживання повноваженнями службовою особою юридичної особи приватного права незалежно від організаційноправової форми (ч. 1 ст. 364-1), зловживання повноваженнями особами, які надають публічні послуги (ч. 1 ст. 365-2).

В юридичній літературі відображена така суперечлива думка: в ч. 1 ст. 96-2 “передбачені умови, за яких майно може підлягати спеціальній конфіскації (вони сформовані шляхом визначення певних категорій майна, що підлягає такому вилученню)”. Водночас зазначене майно слушно називається предметом спеціальної конфіскації. Очевидно, предмет (за законом - об'єкт) спеціальної конфіскації не слід розглядати як умову такого заходу. Ті ознаки окремих категорій майна, що передбачені в законі, насправді характеризують той чи інший предмет спеціальної конфіскації, визначають його юридичну природу (наприклад, предмет злочину, знаряддя чи засоби вчинення злочину).

3. Поняття “умисний злочин” слід визначати з урахуванням положень статей 23-25 КК. При цьому не мають значення стадії злочину - закінчений він чи незакінчений (окрім готування до злочину невеликої тяжкості, яке не тягне за собою кримінальної відповідальності і, відповідно, застосування спеціальної конфіскації), вчинено злочин одноособово чи у співучасті, вид злочину (простий чи ускладнений), види множинності злочинів (повторність, сукупність чи рецидив злочинів). Під час призначення покарання за сукупністю злочинів або сукупністю вироків спеціальна конфіскація застосовується окремо за кожний злочин. Вчинення злочину через необережність не може бути умовою застосування спеціальної конфіскації.

Під поняттям “вилучення” в аспекті коментованої статті слід розуміти позбавлення особи певного майна, яка фактично (законно чи незаконно) утримує його.

Примусовий характер вилучення майна означає, що така дія не залежить від бажання володільця майна, є вимушеною для нього. Такий захід застосовується від імені держави за відповідним рішення суду із застосуванням примусових

DOI (Article): https://doi.org/10.36486/np.2019.2.18

(c) Muzyka Anatolii, 2019 Issue 2(44) 2019 http://naukaipravoohorona.com/ 
механізмів (див., зокрема, ст. 10 Закону “Про виконавче провадження”), якщо особа не виконує зазначене судове рішення в добровільному порядку.

Вилучення майна визнається безоплатним, оскільки при цьому держава не відшкодовує винуватому вартість майна, навіть якщо воно набуте на законних підставах. В аналізованому аспекті спеціальну конфіскацію доречно порівняти 3 реквізицією, коли за певних надзвичайних обставин, з метою суспільної необхідності майно може бути примусово відчужене у власника на підставі та в порядку, встановлених законом, за умови повного відшкодування його вартості (ст. 353 ЦК).

4. Об'єктом (предметом) спеціальної конфіскації можуть бути гроші, цінності, інше майно.

Майном, відповідно до ст. 190 ЦК, вважаються окрема річ, сукупність речей, а також майнові права та обов'язки. Річчю визнається предмет матеріального світу, щодо якого можуть виникати цивільні права та обов'язки. Речі поділяються на рухомі та нерухомі. Рухомими речами є речі, які можна вільно переміщувати у просторі. До нерухомих речей (нерухоме майно, нерухомість) належать земельні ділянки, а також об'єкти, розташовані на земельній ділянці, переміщення яких є неможливим без їх знецінення та зміни їх призначення. Режим нерухомої речі може бути поширений законом на повітряні та морські судна, судна внутрішнього плавання, космічні об'єкти, а також інші речі, права на які підлягають державній реєстрації (статті 179-181 ЦК України).

Зазначимо, що в аспекті розуміння поняття майна у кримінальному та кримінальному процесуальному праві “майнові (“речові”) права та обов’язки” як нематеріальні об’єкти до уваги не слід брати.

Гроші - це передусім гривня як грошова одиниця України (національна валюта); вона є законним платіжним засобом, обов'язковим до приймання за номінальною вартістю на всій території України. Поняттям “гроші” (або “кошти”) охоплюється також іноземна валюта - вона може використовуватися в Україні у випадках і в порядку, встановлених законом (ст. 192 ЦК України). У широкому значенні йдеться про валютні цінності як родове поняття (це, зокрема: національна та іноземна валюта; банківські метали - золото, срібло, платина, метали платинової групи; цінні папери).

Поняття “валютні цінності” МК вживає у такому значенні: “а) валюта України - грошові знаки у вигляді банкнот, казначейських білетів, монет та в інших формах, що перебувають в обігу та є законним платіжним засобом на території України, а також вилучені з обігу або такі, що вилучаються з нього, але підлягають обмінові на грошові знаки, які перебувають в обігу; б) іноземна валюта - іноземні грошові знаки у вигляді банкнотів, казначейських білетів, монет, що перебувають в обігу та є законним платіжним засобом на території відповідної іноземної держави, а також вилучені з обігу або такі, що вилучаються з нього, але підлягають обміну на грошові знаки, які перебувають в обігу; в) платіжні документи та цінні папери (акції, облігації, купони до них, векселі (тратти), боргові розписки, акредитиви, чеки, банківські накази, депозитні сертифікати, інші фінансові та банківські документи), виражені у валюті України, в іноземній валюті або банківських металах; г) банківські метали - золото, срібло, платина, метали платинової групи, доведені (афіновані) до найвищих проб відповідно до світових стандартів, у зливках

DOI (Article): https://doi.org/10.36486/np.2019.2.18

(C) Muzyka Anatolii, 2019

Issue 2(4.4) 2019

http://naukaipravoohorona.com/ 
і порошках, що мають сертифікат якості, а також монети, вироблені з дорогоцінних металів (ч. 1 ст. 4).

Цінності, в аспекті коментованої статті, - це не просто матеріальні цінності, a їх різновид: зокрема, дорогоцінні метали, коштовне каміння, ювелірні вироби (каблучки, сережки, підвіски, ланцюжки, обручки, печатки, браслети, брошки, затискачі, запонки тощо). Це може бути майно або скарб, які мають особливу історичну, наукову, художню чи культурну цінність; у широкому розумінні культурні цінності.

“Інше майно" - це, наприклад: транспорті засоби (зокрема, всі види автомобілів, трактори та інші самохідні машини, а також мотоцикли та інші механічні транспортні засоби); тварини (на них поширюється правовий режим речі, крім випадків, встановлених законом), підприємства як єдиний майновий комплекс (до їх складу входять усі види майна, призначені для його діяльності, включаючи, зокрема, земельні ділянки, будівлі, споруди, устаткування, інвентар, сировину, продукцію); одяг, продукти харчування, побутову техніку, картини.

5. Зміст виразу “майно, вилучене з цивільного обороту" слід розкривати через ознаки поняття “оборотоздатність об’єктів цивільних прав”. У ч. 1 ст. 178 ЦК проголошена презумпція вільної оборотоздатності об'єктів цивільних прав: останні “можуть вільно відчужуватися або переходити від однієї особи до іншої в порядку правонаступництва чи спадкування або іншим чином, якщо вони не вилучені 3 цивільного обороту, або не обмежені в обороті, або не є невід'ємними від фізичної чи юридичної особи”. Отже, за ступенем оборотоздатності об'єкти цивільних прав поділяються на три види: 1) об'єкти, які перебувають у вільному цивільному обороті; 2) об’єкти, які обмежені в обороті; 3) об’єкти, які вилучені з цивільного обороту.

Види об'єктів цивільних прав, перебування яких у цивільному обороті не допускається (об'єкти, вилучені з цивільного обороту), мають бути безпосередньо встановлені у законі (ч. 2 ст. 178 ЦК). Вилученим із цивільного обороту вважається майно, яке згідно із законом не може бути предметом цивільних правочинів. Зокрема, ядерні матеріали перебувають лише у загальнодержавній власності (ст. 9 Закону "Про використання ядерної енергії та радіаційну безпеку" від 8 лютого 1995 р.); усі пам'ятки археології є державною власністю (ст. 17 Закону "Про охорону культурної спадщини” від 8 червня 2000 р.); об'єкти природно-заповідного фонду України - державні заповідники, природні національні парки, заказники, пам'ятки природи, ботанічні сади, дендрологічні та зоологічні парки, парки-пам'ятки садово-паркового мистецтва, заповідні урочища також вилучені з цивільного обороту (ст. 61 Закону “Про охорону навколишнього природного середовища” від 25 червня 1991 р.).

Не можуть бути предметом цивільних правочинів, наприклад, особливо небезпечні наркотичні засоби і психотропні речовини, а також їх аналоги, порнографічні видання, підроблені грошові знаки і платіжні документи, оскільки вони заборонені до обігу в Україні.

Так само встановлюються законом види об’єктів цивільних прав, які можуть належати лише певним учасникам обороту або перебування яких у цивільному обороті допускається за спеціальним дозволом (об'єкти, обмежено оборотоздатні).

DOI (Article): https://doi.org/10.36486/np.2019.2.18

(C) Muzyka Anatolii, 2019 Issue 2(44) 2019 http://naukaipravoohorona.com/ 
Це означає, що певне майно не може перебувати у власності фізичних і юридичних осіб, міжнародних організацій та юридичних осіб інших держав на території України. Наприклад, бойова і спеціальна військова техніка, спеціальні технічні засоби негласного отримання інформації. До обмежено оборотоздатних об’єктів належить і майно, для здійснення правочинів з якими вимагається спеціальний дозвіл (ліцензія) - зокрема, для торгівлі алкогольними напоями і тютюновими виробами, для правочинів зі спортивною та мисливською зброєю.

6. Якщо об’єктом спеціальної конфіскації є майно, вилучене з цивільного обороту, вона може бути застосована на підставі одного з таких рішень: 1) ухвали суду про закриття кримінального провадження з інших підстав, аніж звільнення особи від кримінальної відповідальності; 2) ухвали суду, постановленої в порядку ч. 9 ст. 100 КПК, за клопотанням слідчого чи прокурора, якщо кримінальне провадження закривається ними (ч. 3 ст. 96-1).

Перша підстава застосування спеціальної конфіскації, що передбачена ч. 3 ст. 96-1, реалізується відповідно до абз. 2 ч. 7 ст. 284 КПК: “Якщо обставини, передбачені пунктами 5, 6, 7, 8, 9, 10 частини першої ст. 284 КПК, виявляються під час судового провадження, а також у випадку, передбаченому пунктами 2, 3 частини другої цієї статті, суд постановляє ухвалу про закриття кримінального провадження". Кримінальне провадження закривається судом відповідно до приписів ч. 1 ст. 284 КПК, якщо:

помер підозрюваний, обвинувачений, крім випадків, якщо провадження є необхідним для реабілітації померлого (п. 5);

існує вирок по тому самому обвинуваченню, що набрав законної сили, або постановлена ухвала суду про закриття кримінального провадження по тому самому обвинуваченню (п. 6);

потерпілий, а у випадках, передбачених КПК, його представник відмовився від обвинувачення у кримінальному провадженні у формі приватного обвинувачення (п. 7); (п. 8);

стосовно злочину, щодо якого не отримано згоди держави, яка видала особу

стосовно податкових зобов'язань особи, яка вчинила дії, передбачені ст. 212 КК, досягнутий податковий компроміс відповідно до підрозділу 9-2 розділу ХХ “Перехідні положення” ПК (п. 9);

існує нескасована постанова слідчого, прокурора про закриття кримінального провадження $з$ підстав, передбачених пунктами 1, 2, 4, 9 частини першої КПК, у кримінальному провадженні щодо того самого діяння, що розслідувалося із дотриманням вимог щодо підслідності (п. 10).

Кримінальне провадження закривається судом відповідно до приписів ч. 2 ст. 284 КПК, якщо:

прокурор відмовився від підтримання державного обвинувачення, за винятком випадків, передбачених КПК (п. 2);

досягнуто податковий компроміс у справах про злочини, передбачені ст. 212 КК, відповідно до підрозділу 9-2 розділу ХХ “Перехідні положення” ПК (п. 3).

Друга підстава застосування спеціальної конфіскації, що передбачена ч. 3 ст. 96-1 КК, реалізується судом згідно з приписами ч. 9 ст. 100 КПК. Для цього

DOI (Article): https://doi.org/10.36486/np.2019.2.18

(c) Muzyka Anatolii, 2019 
вимагається відповідне клопотання слідчого чи прокурора, які закривають кримінальне провадження. Слідчий ухвалює постанову про закриття кримінального провадження з підстав, передбачених пунктами 1, 2, 4, 9, 10 частини першої статті 284 КПК, якщо в цьому кримінальному провадженні жодній особі не повідомлялося про підозру. Прокурор ухвалює постанову про закриття кримінального провадження щодо підозрюваного з підстав, передбачених частиною першою цієї статті (ч. 4 ст. 284 КПК).

7. Неоподатковуваний мінімум доходів громадян - грошова сума розміром у 17 гривень, встановлена п. 5 підрозділу 1 розділу ХХ ПК. Про види звільнення від кримінальної відповідальності див. розділ IX, статті 97, 106 КК; про застосування примусових заходів медичного характеру - статті 92 - 95 КК; про застосування примусових заходів виховного характеру - статті 97, 105 КК.

8. Таким чином, спеціальна конфіскація (лат. confiskatio - вилучення майна у державну скарбницю) є одним із кримінально-правових заходів - примусовим безоплатним вилученням у володільця за рішенням суду у власність держави певного майна (його різновиди визначені у ч. 1 ст. 96-2), якщо вчинено умисний злочин (або суспільно небезпечне діяння), за які встановлено основне покарання у виді позбавлення волі чи штрафу понад три тисячі неоподатковуваних мінімумів доходів громадян, або за умови вчинення умисного злочину невеликої тяжкості (суспільно небезпечного діяння), передбаченого для таких випадків у відповідному переліку посягань (ч. 1 ст. 96-1).

Цей захід зумовлений кримінально-правовими відносинами, але не є покаранням (зокрема, його не слід плутати з конфіскацією майна як видом покарання). Схожими вони є лише за двома ознаками: конфіскація майна застосовується виключно за рішенням суду; конфісковане майно безоплатно переходить у власність держави (ч. 6 ст. 41 Конституції, ст. 354 ЦК, ч. 1 ст. 59 КК). Натомість інші обов'язкові ознаки конфіскації майна (покарання) не притаманні спеціальній конфіскації, і навпаки.

Порівнюючи поняття “конфіскація майна” і “спеціальна конфіскація”, слід враховувати, зокрема, таке. Спеціальна конфіскація, як правило, не позбавляє особу права власності, оскільки вилучається майно, що пов'язане з фактом вчинення злочину або суспільно небезпечного діяння; цей захід не є санкцією за вчинення злочину (відповідного суспільно небезпечного діяння); може застосовуватися не лише за вчинення злочину, а й за суспільно небезпечне діяння, що підпадає під ознаки діяння, передбаченого Особливою частиною КК України; предметом (об'єктом) спеціальної конфіскації може бути не лише майно особи, яка вчинила злочин, а й майно осіб, які: а) не є суб'єктом певного злочину - неосудні та особи, що не досягли віку кримінальної відповідальності; б) звільнені від кримінальної відповідальності чи покарання (крім звільнення від кримінальної відповідальності у зв'язку із закінченням строків давності); в) є “третіми особами”; умовою застосування спеціальної конфіскації не може бути вчинення злочину через необережність - вона застосовується за умови вчинення лише умисного злочину (відповідного суспільно небезпечного діяння); можливість застосування спеціальної конфіскації не обмежена умовою вчинення лише тяжкого та особливо тяжкого корисливого злочину, чи злочину проти основ національної безпеки України та

DOI (Article): https://doi.org/10.36486/np.2019.2.18

(C) Muzyka Anatolii, 2019 Issue 2(44) 2019 http://naukaipravoohorona.com/ 
громадської безпеки (відповідного суспільно небезпечного діяння) - це може бути тяжкий чи особливо тяжкий злочин, не обтяжений корисливими спонуканнями, а так само злочин невеликої чи середньої тяжкості, що не обов'язково посягає на громадську безпеку.

Оскільки спеціальна конфіскація не є покаранням, на неї не поширюються положення КК про покарання, призначення покарання, звільнення від покарання та його відбування (розділи X-XII, XV). Ї̈̈ застосування не тягне за собою настання судимості.

Спеціальну конфіскацію необхідно відрізняти і від конфіскації майна як одного із заходів кримінально-правового характеру, що застосовується судом за відповідних підстав до юридичної особи у разі ліквідації останньої. Про поняття “заходи кримінально-правового характеру щодо юридччних осіб” див. розділ XIV1 Загальної частини КК.

Також спеціальну конфіскацію (кримінально-правовий захід) слід відмежовувати і від таких заходів забезпечення кримінального провадження (кримінальнопроцесуальних заходів), як: накладення грошового стягнення (глава 12 КПК), тимчасовий доступ до речей і документів (глава 15 КПК), тимчасове вилучення майна (глава 16 КПК), арешт майна (глава 17 КПК). Зокрема, тимчасовим вилученням майна визнається фактичне позбавлення підозрюваного або осіб, у володінні яких перебуває певне майно (зазначене у ч. 2 ст. 167 КПК), можливості володіти, користуватися та розпоряджатися таким майном до вирішення питання про арешт майна або його повернення (ч. 1 ст. 167 КПК).

Тимчасово вилученим може бути майно у вигляді речей, документів, грошей тощо, щодо яких є достатні підстави вважати, що вони:

1) підшукані, виготовлені, пристосовані чи використані як засоби чи знаряддя вчинення злочину та (або) зберегли на собі його сліди; 2) призначалися (використовувалися) для схиляння особи до вчинення злочину, фінансування та/або матеріального забезпечення злочину або винагороди за його вчинення; 3) $є$ предметом злочину, у тому числі пов'язаного з їх незаконним обігом; 4) одержані внаслідок вчинення злочину та/або є доходами від них, а також майно, в яке їх було повністю або частково перетворено (ч. 2 ст. 167 КПК).

Відповідно до ч. 2 ст. 170 КПК арешт майна допускається з метою забезпечення: 1) збереження речових доказів; 2) спеціальної конфіскації; 3) конфіскації майна як виду покарання або заходу кримінально-правового характеру щодо юридичної особи; 4) відшкодування шкоди, завданої внаслідок злочину (цивільний позов), чи стягнення з юридичної особи отриманої неправомірної вигоди.

\section{Стаття 96-2. Випадки застосування спеціальної конфіскації}

1. Спеціальна конфіскація застосовується у разі, якщо гроші, цінності та інше майно: майна;

1) одержані внаслідок вчинення злочину та/або є доходами від такого

2) призначалися (використовувалися) для схиляння особи до вчинення злочину, фінансування та/або матеріального забезпечення злочину або винагороди за його вчинення;

DOI (Article): https://doi.org/10.36486/np.2019.2.18

(C) Muzyka Anatolii, 2019

Issue 2(4.4) 2019

http://naukaipravoohorona.com/ 
3) були предметом злочину, крім тих, що повертаються власнику (законному володільцю), а у разі, коли його не встановлено, - переходять у власність держави;

4) були підшукані, виготовлені, пристосовані або використані як засоби чи знаряддя вчинення злочину, крім тих, що повертаються власнику (законному володільцю), який не знав і не міг знати про їх незаконне використання.

2. У разі якщо гроші, цінності та інше майно, зазначені у пункті 1 частини першої цієї статті, були повністю або частково перетворені в інше майно, спеціальній конфіскації підлягає повністю або частково перетворене майно. Якщо конфіскація грошей, цінностей та іншого майна, зазначених у пункті 1 частини першої цієї статті, на момент прийняття судом рішення про спеціальну конфіскацію неможлива внаслідок їх використання або неможливості виділення 3 набутого законним шляхом майна, або відчуження, або з інших причин, суд виносить рішення про конфіскацію грошової суми, що відповідає вартості такого майна.

3. Спеціальна конфіскація застосовується також у разі, коли особа не підлягає кримінальній відповідальності у зв'язку з недосягненням віку, з якого може наставати кримінальна відповідальність, або неосудністю, або звільняється від кримінальної відповідальності чи покарання з підстав, передбачених цим Кодексом, крім звільнення від кримінальної відповідальності у зв'язку із закінченням строків давності.

4. Гроші, цінності, в тому числі кошти, що знаходяться на банківських рахунках чи на зберіганні у банках або інших фінансових установах, інше майно, зазначені в цій статті, підлягають спеціальній конфіскації у третьої особи, якщо вона набула таке майно від підозрюваного, обвинуваченого, особи, яка переслідується за вчинення суспільно небезпечного діяння у віці, з якого не настає кримінальна відповідальність, або в стані неосудності, чи іншої особи безоплатно, за ринкову ціну або за ціну вищу чи нижчу ринкової вартості, і знала або повинна була і могла знати, що таке майно відповідає будьякій із ознак, зазначених у пунктах 1-4 частини першої цієї статті.

Вищезазначені відомості щодо третьої особи повинні бути встановлені в судовому порядку на підставі достатності доказів.

Спеціальна конфіскація не може бути застосована до майна, яке перебуває у власності добросовісного набувача.

5. Спеціальна конфіскація не застосовується до грошей, цінностей та іншого майна, зазначених у цій статті, які згідно із законом підлягають поверненню власнику (законному володільцю) або призначені для відшкодування шкоди, завданої злочином.

\{Частину шосту статті 96-2 виключено на підставі Закону № 1019-VIII від 18.02.2016\}

(Кодекс доповнено статтею 96-2 згідно із Законом № 222-VII від 18.04.2013; із змінами, внесеними згідно із Законами № 1261-VII від 13.05.2014, № 770-VIII від 10.11.2015, № 1019-VIII від 18.02.2016)

1. Закон передбачає низку альтернативних випадків застосування спеціальної конфіскації. Вона застосовується у разі, якщо гроші, цінності та інше майно

DOI (Article): https://doi.org/10.36486/np.2019.2.18

(C) Muzyka Anatolii, 2019

Issue 2(44) 2019

http://naukaipravoohorona.com/ 
певною мірою були пов'язані з фактом вчинення умисного злочину чи відповідного суспільно небезпечного діяння, що передбачені ч. 1 ст. 96-1.

У п. 1 ч. 1 ст. 96-2 йдеться про майно, одержане внаслідок вчинення злочину та/або є доходами від такого майна. Це випадки, коли особа незаконно набула право власності на зазначене майно чи одержала його у фактичне володіння.

Положення цього пункту мають застосовуватись, наприклад, у випадках, коли внаслідок збуту наркотичних засобів винуватий одержав певні кошти або інше майно (“одержані внаслідок вчинення злочину”). Аналогічним за походженням буде предмет спеціальної конфіскації у разі заздалегідь не обіцяного зберігання (наприклад, за матеріальну винагороду) чи збуту (як оплатної реалізації) майна, завідомо одержаного злочинним шляхом (ст. 198). Натомість неправомірна вигода, що виражена у грошах, цінностях чи іншому майні, - як предмет злочину, передбаченого ст. 368, підлягає спеціальній конфіскації відповідно до п. 3 ч. 1 ст. 96-2.

Дохід (доход) - це кошти або матеріальні цінності, одержувані особою в результаті якої-небудь діяльності. Відповідно до ч. 1 ст. 189 ЦК продукцією, плодами та доходами є все те, що виробляється, добувається, одержується з речі або приноситься річчю.

“Доходи від такого майна" - це, наприклад, доходи від оренди житла чи іншого приміщення, одержаного внаслідок шахрайства (відповідного суспільно небезпечного діяння); доходи від такого виду оренди, як лізинг (зокрема, довгострокова оренда викраденого обладнання, видача його напрокат); відсотки, нараховані на банківські вклади (предметом вкладу має бути майно, що одержане внаслідок вчинення злочину); кошти, одержані від реалізації товарів чи іншого майна, здобутого злочинним шляхом; виручка підприємства (створеного з метою прикриття незаконної діяльності, що карається за ст. 205) від реалізації продукції, надання послуг та виконання робіт. Це може бути і роялті - будь-який платіж, отриманий як винагорода за використання або за надання права на використання об’єкта права інтелектуальної власності (підпункт 14.1.225 пункту 14.1 статті 14 ПК), якщо такі дії (використання або надання права на використання...) пов’язані із шахрайством.

У всіх випадках поняття “дохід” охоплює витрати, пов’язані з платою податків, комунальними платежами тощо. Дохід може бути отриманий як на території України, так і з джерел за межами України.

Відповідно до ПК дохід з джерелом його походження з України - це будьякий дохід, отриманий резидентами або нерезидентами, у тому числі від будьяких видів їх діяльності на території України (включаючи виплату (нарахування) винагороди іноземними роботодавцями), її континентальному шельфі, у виключній (морській) економічній зоні, у тому числі, але не виключно, доходи у вигляді: а) процентів, дивідендів, роялті та будь-яких інших пасивних (інвестиційних) доходів, сплачених резидентами України; б) доходів від надання резидентам або нерезидентам в оренду (користування) майна, розташованого в Україні, включаючи рухомий склад транспорту, приписаного до розташованих в Україні портів; в) доходів від продажу рухомого та нерухомого майна, доходів від відчуження корпоративних прав, цінних паперів, у тому числі акцій українських емітентів;

DOI (Article): https://doi.org/10.36486/np.2019.2.18

(c) Muzyka Anatolii, 2019 Issue 2(4.4) 2019 http://naukaipravoohorona.com/ 
г) доходів, отриманих у вигляді внесків та премій на страхування і перестрахування ризиків на території України; г) доходів страховиків - резидентів від страхування ризиків страхувальників - резидентів за межами України; д) інших доходів від діяльності, у тому числі пов'язаних з повною або частковою переуступкою прав та обов’язків за угодами про розподіл продукції на митній території України або на територіях, що перебувають під контролем контрольних органів (у зонах митного контролю, на спеціалізованих ліцензійних митних складах тощо); е) спадщини, подарунків, виграшів, призів; є) заробітної плати, інших виплат та винагород, виплачених відповідно до умов трудового та цивільно-правового договору; ж) доходів від зайняття підприємницькою та незалежною професійною діяльністю (підпункт 14.1.54 пункту 14.1 статті 14).

ПК також визначає дохід, отриманий з джерел за межами України, - це будь-який дохід, отриманий резидентами, у тому числі від будь-яких видів їх діяльності за межами митної території України, включаючи проценти, дивіденди, роялті та будь-які інші види пасивних доходів, спадщину, подарунки, виграші, призи, доходи від виконання робіт (надання послуг) за цивільно-правовими та трудовими договорами, від надання резидентам в оренду (користування) майна, розташованого за межами України, включаючи рухомий склад транспорту, приписаного до розташованих за межами України портів, доходи від продажу майна, розташованого за межами України, дохід від відчуження інвестиційних активів, у тому числі корпоративних прав, цінних паперів тощо; інші доходи від будьяких видів діяльності за межами митної території України або територій, непідконтрольних контрольним органам (підпункт 14.1.55 пункту 14.1 статті 14).

Про поняття “проценти” як дохід див. підпункт 14.1.206 пункту 14.1 статTi 14.

2. У п. 2 ч. 1 ст. 96-2 зазначено: майно, що призначалося (використовувалося) для схиляння особи до вчинення злочину, фінансування та/або матеріального забезпечення злочину або винагороди за його вчинення.

Схиляння особи до вчинення злочину - це будь-які умисні дії, спрямовані на те, щоб збудити в іншої особи бажання чи добитися від неї згоди вчинити кримінально каране діяння (умовляння, підкуп, пропозиція, порада, переконування, примушування, погрози, застосування насильства тощо). Такі дії загалом є своєрідним підбурюванням до вчинення злочину (ч. 4 ст. 27). Однак винуватий може бути і виконавцем злочину - у випадках, коли особа, яка вчинила суспільно небезпечне діяння, була в стані неосудності чи не досягла віку кримінальної відповідальності. Окрім того, закон розрізняє майно, що призначалося (винуватий планував його використати), і майно, що використовувалося (реально застосовувалося) для схиляння особи до вчинення злочину. Це дозволяє зробити висновок, що коментоване положення статті (про схиляння) не слід розуміти буквально як підбурювання до вчинення злочину - коли підбурювач фактично схилив іншого співучасника до вчинення злочину. Тобто не вимагається аби адресат схиляння насправді вчинив злочин.

Також необхідно мати на увазі: відповідно до п. 2 ч. 1 ст. 96-2 майно підлягатиме спеціальній конфіскації, якщо воно у цьому випадку використано (призначалося для використання) безпосередньо власником майна. Якщо ж майно, що

DOI (Article): https://doi.org/10.36486/np.2019.2.18

(c) Muzyka Anatolii, 2019 Issue 2(44) 2019 http://naukaipravoohorona.com/ 
призначалося (використовувалося) для схиляння особи до вчинення злочину, фінансування та/або матеріального забезпечення злочину або винагороди за його вчинення, не належало винуватому, а власник не знав про такі дії з його майном, воно не може бути предметом спеціальної конфіскації; остання можлива лише у разі пособництва власника майна у вчиненні відповідного злочину.

Водночас не береться до уваги, чи особа, яку мали схилити чи схиляли до вчинення злочину, була обізнана про походження майна. Те саме стосується і випадків, коли майно призначалося (використовувалося) для фінансування та/або матеріального забезпечення злочину або винагороди за його вчинення.

Під винагородою за вчинення злочину слід розуміти незаконну вигоду матеріального характеру. Це гроші, цінності та інше майно, що призначалися чи використовувалися винуватим як “плата” за вчинення певного злочину (відповідного суспільно небезпечного діяння), передбаченого ч. 1 ст. 96-1.

3. У пунктах 3, 4 частини 1 коментованої статті йдеться про застосування спеціальної конфіскації щодо предметів злочину, засобів $і$ знарядь вчинення злочину. Під час встановлення предмета будь-якого злочину необхідно мати на озброєнні визначення загального поняття предмета злочину. При цьому варто керуватися таким його визначенням: предмет злочину - це факультативна ознака об'єкта злочину, що знаходить свій прояв у матеріальних цінностях (котрі людина може сприймати органами чуття чи фіксувати спеціальними технічними засобами), 3 приводу яких та шляхом безпосереднього впливу на які (або без такого впливу) вчиняється злочинне діяння.

У визначенні поняття предмета злочину як матеріальних цінностей використана філософська категорія “цінності”. Відповідно категорію цінностей доцільно розглядати у широкому значенні - цінності можуть бути і позитивними (благами), і негативними (антиблагами). Позитивними цінностями можуть бути, наприклад, гроші, наркотичні лікарські засоби, психотропні лікарські препарати; негативними - підроблені гроші, особливо небезпечні наркотичні засоби чи психотропні речовини.

Предмет конкретного злочину має свої особливості, однак визначення його поняття не повинно суперечити суті загального поняття предмета злочину.

Знаряддя вчинення злочину - це факультативна ознака об’єктивної сторони складу злочину, що характеризує матеріальні цінності, котрі використовуються винуватим для безпосереднього впливу на потерпілого від злочину та (або) на предмет злочину і при цьому мають “первинний контакт” з ними, посилюють фізичні можливості суб’єкта злочину під час вчинення суспільно небезпечної дії (в окремих випадках їх відсутність унеможливлює таке посягання). Наприклад, знаряддям вчинення окремих злочинів може бути холодна чи вогнепальна зброя.

Засоби вчинення злочину - це факультативна ознака об'єктивної сторони складу злочину, що характеризує матеріальні цінності, які полегшують вчинення суспільно небезпечної дії, але не призначені для безпосереднього впливу на потерпілого від злочину та (або) на предмет злочину. Зокрема, транспортний засіб, що застосовувався для перевезення злочинців, викраденого майна, знарядь вчинення злочину.

DOI (Article): https://doi.org/10.36486/np.2019.2.18

(c) Muzyka Anatolii, 2019

Issue 2(4.4) 2019

http://naukaipravoohorona.com/ 
Знаряддя і засоби вчинення злочину характеризуються низкою спільних ознак. Як знаряддя, так і засоби вчинення злочину є матеріальними цінностями. Вони суттєво полегшують вчинення злочину. Знаряддя і засоби притаманні лише тим злочинам, які вчиняються у формі суспільно небезпечної дії. У складі злочину - це факультативні ознаки об’єктивної сторони діяння.

Водночас знаряддя злочину потрібно відрізняти від засобів його вчинення. Під час розмежування цих ознак допустимо використовувати такі правила, що мають застосовуватися у їх сукупності.

1) Знаряддя вчинення злочину посилюють фізичні можливості суб’єкта злочину під час вчинення суспільно небезпечної дії (в окремих випадках їх відсутність унеможливлює таке посягання), відіграють домінуючу, а засоби вчинення злочину - другорядну роль у процесі заподіяння шкоди. Знаряддя безпосередньо впливають на предмет злочину та (або) на потерпілого від злочину і при цьому мають “первинний контакт” з ними, а засоби - лише полегшують вчинення суспільно небезпечної дії, вони не завжди контактують з предметом посягання чи потерпілим від злочину.

2) Засоби вчинення злочину можуть використовуватися на будь-якій стадії вчинення злочину; знаряддя не використовуються на стадії готування до злочину.

3) Існування знарядь вчинення злочину залежить від наявності предмета посягання та (або) потерпілого від злочину - за відсутності останніх у складі злочину не існує і знарядь його вчинення; засоби вчинення злочину не характеризуються такою залежністю.

Слід пам'ятати, що одні й ті самі матеріальні цінності в одному випадку можуть бути предметом злочину (наприклад, незаконне заволодіння транспортним засобом), в інших - знаряддям вчинення злочину (умисний наїзд транспортним засобом на людину з метою позбавлення іï життя), або ж засобом вчинення злочину (перевезення транспортним засобом викраденого майна, знарядь вчинення злочину). Чітке уявлення про особливості понять “предмет злочину”, “знаряддя вчинення злочину” і “засоби вчинення злочину” має практичне значення, зокрема, для правильної кваліфікації суспільно небезпечного діяння, розмежування загальних і спеціальних кримінально-правових норм. А з цим, у свою чергу, пов’язане питання про застосування (незастосування) спеціальної конфіскації.

Про поняття "підшукування", “виготовлення" і “пристосування" засобів $і$ знарядь вчинення злочину див. ст. 14. Використання засобів чи знарядь вчинення злочину означає, що особа застосовує їх під час вчинення кримінально караного діяння.

Певні засоби чи знаряддя вчинення злочину, залежно від їх походження, повертаються власнику (законному володільцю), який не знав і не міг знати про їх незаконне використання. Необізнаність власника (законного володільця) про використання його майна в якості знаряддя чи засобу вчинення злочину, а також відсутність у нього реальної можливості знати про це, є сукупним фактом, що належить до предмета доказування в судовому провадженні. Наприклад, викрадена в особи рушниця у подальшому використовувалась як знаряддя вбивства, про що не було відомо власнику. Якщо ж буде встановлено, що власник (законний володілець) не знав, але міг знати про обставини використання його майна, воно підлягає спеціальній конфіскації.

DOI (Article): https://doi.org/10.36486/np.2019.2.18

(C) Muzyka Anatolii, 2019 
Окремі предмети злочину також повертаються власнику (законному володільцю). Йдеться, зокрема, про його майно (гроші, автомобіль тощо). Якщо власника (законного володільця) майна не буде встановлено, предмети злочину переходять у власність держави. У цьому разі не йдеться про спеціальну конфіскацію. Таке рішення суду не є остаточним, власник (законний володілець) майна має право вимагати повернення його у цивільно-правовому порядку.

4. Поняття “володілещь” може вживатися в багатьох значеннях. У широкому розумінні володілець - це будь-який суб'єкт цивільного права, який фактично (законно чи незаконно) утримує певну річ.

Законний (титульний) володілещь - це особа, яка фактично утримує річ як іiї власник, а також особа, яка є фактичним утримувачем речі на підставі договору або безпосередніх застережень закону. ЦК України виокремлює категорію володільця чужого майна. Так, володільцем чужого майна є особа, яка фактично тримає його у себе. При цьому фактичне володіння майном вважається правомірним, якщо інше не випливає із закону або не встановлено рішенням суду (ч. 1, 3 ст. 397).

Володілець може бути добросовісним або недобросовісним. “Якщо майно за відплатним договором придбане в особи, яка не мала права його відчужувати, про що набувач не знав і не міг знати”, така особа (набувач) визнається добросовісним набувачем (ч. 1 ст. 388 ЦК). За змістом ст. 388 ЦК добросовісним вважається придбання майна не безпосередньо у власника, а в особи, яка не мала права його відчужувати (див.: ухвала колегії суддів Судової палати у цивільних справах Верховного Суду України від 15 квітня 2009 р. // Вісник Верховного Суду України. 2010. № 4). Важливо пам’ятати, що існує презумпція добросовісності набувача - незаконний набувач буде вважатися добросовісним доти, доки не буде доведено протилежне.

5. Відповідно до міжнародно-правових вимог, зокрема Конвенції ООН проти корупції від 31 жовтня 2003 (частини 4 - 6 статті 31), КК передбачає застосування так званої еквівалентної конфіскації. Предметом останньої є перетворене майно або грошова сума, що відповідає вартості майна, одержаного внаслідок вчинення злочину та/або є доходами від зазначеного майна.

У цивільному законодавстві поняття “перетворення” вживається в аспекті припинення юридичної особи (статті 104, 108 ЦК), що не є прийнятним для коментування положень про спеціальну конфіскацію. Натомість ст. 332 ЦК регламентує питання про набуття права власності на перероблену річ: “переробкою $є$ використання однієї речі (матеріалу), в результаті чого створюється нова річ” (ч. 1). Очевидно, терміни “перетворення" і “переробка" майна є синонімами слова хоча й відмінні, але однакові або дуже близькі своїм значенням.

Під поняттям “перетворення майна" слід розуміти певні дії, процеси, внаслідок яких майну надається нового вигляду, добавляється яка-небудь якість (властивість), воно переводиться в інший стан. Наприклад, за гроші придбано товар; засіб вчинення злочину (автомобіль) проданий за певну грошову суму; лісовий матеріал (колоди) і цегла використані для будівництва гаража.

У разі повного або часткового перетворення майна, зазначеного у п. 1 ч. 1 коментованої статті, в інше майно, таке перетворене майно підлягає спеціальній

DOI (Article): https://doi.org/10.36486/np.2019.2.18

(C) Muzyka Anatolii, 2019

Issue 2(4.4) 2019

http://naukaipravoohorona.com/ 
конфіскації. Якщо на момент ухвалення судом рішення про спеціальну конфіскацію iii неможливо застосувати (внаслідок використання майна або неможливості виділення його з набутого законним шляхом майна, або відчуження, або з інших причин), суд ухвалює рішення про конфіскацію грошової суми, що відповідає вартості такого майна (ч. 2 ст. 96-2). Зазначені кошти підлягають примусовому безоплатному вилученню, оскільки мають злочинне походження. Цим, зокрема, спеціальна конфіскація відрізняється від покарання у виді штрафу (грошового стягнення), предмет якого - законно набуті кошти.

У випадках конфіскації грошової суми, що відповідає вартості перетвореного майна, може виникнути потреба у проведенні відповідної товарознавчої або іншої експертизи.

6. Відповідно до ч. 3 ст. 96-2 спеціальна конфіскація застосовується також у разі, коли особа: а) не підлягає кримінальній відповідальності у зв'язку 3 недосягненням віку, з якого може наставати кримінальна відповідальність, або б) неосудністю, або в) звільняється від кримінальної відповідальності чи покарання з підстав, передбачених КК (за винятком звільнення від кримінальної відповідальності у зв'язку із закінченням строків давності).

“Звільнення від покарання" у даному випадку слід розуміти у широкому значенні, тобто як інститут “звільнення від покарання та його відбування”.

Варто взяти до уваги, що застереження про незастосування спеціальної конфіскації не поширюється на випадки звільнення від відбування покарання у зв'язку із закінченням строків давності виконання обвинувального вироку (ст. 80).

Водночас застереження про незастосування спеціальної конфіскації у разі звільнення особи від кримінальної відповідальності у зв’язку із закінченням строків давності не є абсолютним, оскільки давність не застосовується у разі вчинення злочинів проти: основ національної безпеки України (статті 109-114-1), миру та безпеки людства (статті 437-439, ч. 1 ст. 442 КК (ч. 5 ст. 49).

7. Законом встановлена можливість спеціальної конфіскації майна “третіх осіб” (ч. 4 ст. 96-2). Цей термін застосовується у нормах цивільного матеріального і процесуального права і позначає віддалених від суб'єктів правовідносин осіб (наприклад, у статтях 52, 53 ЦПК). За КПК, “третьою особою, щодо майна якої вирішується питання про арешт, може бути будь-яка фізична або юридична особи” (ч. 1 ст. 64-2). Така особа належить до учасників кримінального (судового) провадження (пункти 25, 26 ч. 1 ст. 3 КПК).

Можливість визнання “третьою особою” юридичної особи суперечить ознакам аналізованого поняття, що передбачені ст. 96-2 КК. В аспекті коментованої норми третя особа - це винятково фізична особа, яка безпосередньо не причетна до вчинення злочину (суспільно небезпечного діяння), передбаченого ч. 1 ст. 96-1. Спеціальну конфіскацію до третьої особи можна застосувати у разі якщо така особа:

1) набула (стала власником, придбала, незаконно заволоділа) майно, зазначене у пунктах 1-4 частини першої статті 96-2, від: а) підозрюваного чи обвинуваченого, або б) особи, яка переслідується за вчинення суспільно небезпечного діяння у віці, з якого не настає кримінальна відповідальність, або в) особи, яка вчинила відповідне суспільно небезпечне діяння в стані неосудності, або г) іншої особи;

DOI (Article): https://doi.org/10.36486/np.2019.2.18

(c) Muzyka Anatolii, 2019 
2) знала або повинна була і могла знати про походження такого майна.

Той факт, що третя особа “знала або повинна була $і$ могла знати” про походження майна (про те, що воно відповідає будь-якій із ознак, зазначених у пунктах 1-4 частини першої статті 96-2), потребує доказування. При цьому до уваги беруться як об'єктивні (наприклад, особа кимось була поінформована про: доходи від майна, одержаного внаслідок вчинення злочину; наявність знарядь і засобів його вчинення), так і суб’єктивні обставини - здатність особи (з урахуванням віку, інтелектуальних можливостей, стану здоров’я) усвідомити відповідну подію. Все це свідчить на користь визнання третьою особою лише фізичних осіб.

Привертає увагу непослідовність законодавця: у випадку з “третьою особою” використовуються дві альтернативні умови щодо обізнаності про походження майна (особа "знала" або "повинна була і могла знати"); у п. 4 ч. 1 ст. 96-2 використана інша формула: майно повертається власнику (законному володільцю), який “не знав і не міг знати” про його незаконне використання. У цьому випадку передбачена безальтернативна умова і відсутня ознака "не повинен був". Наведені обставини необхідно враховувати під час застосування спеціальної конфіскації.

Зазначені відомості щодо третьої особи мають бути встановлені в судовому порядку на підставі належних доказів. При цьому не береться до уваги, безоплатний чи оплатний характер мало придбання майна. Неважливо і те, за яку ціну воно набуто.

Iнші особи - це будь-які фізичні особи, незалежно від їх причетності до вчинення злочину (суспільно небезпечного діяння), передбаченого ч. 1 ст. 96-1, а також юридичні особи, від яких “третя особа” набула відповідне майно.

8. У ч. 4 ст. 96-2 йдеться, зокрема, про особу, “яка переслідується за вчинення суспільно небезпечного діяння...”. За тлумачними словниками, поняття “переслідування" може вживатися у багатьох значеннях. Саме такий підхід спостерігається у відповідних нормах КК і КПК. При цьому визначення аналізованого поняття відсутнє. Так, окрім ч. 4 ст. 96-2, воно згадується ще у двох статтях КК, а саме: “...переслідування журналіста у зв'язку з його законною професійною діяльністю” (ч. 2 ст. 171) та в аспекті “жертв нацистських переслідувань” (ч. 2, 3 ст. 297).

Неоднаковий смисл відображено цим терміном і в п’ятьох статтях КПК:

“... під час безперервного переслідування особи, яка підозрюється у його вчиненні” (п. 2 ч. 2 ст. 207); “...пов'язаних... з безпосереднім переслідуванням осіб, які підозрюються...” (ч. 3 ст. 233); “...перейняття кримінального переслідування...” (ч. 1 ст. 542); “...переслідування, засудження або покарання особи за ознаками її раси, кольору шкіри...” (п. 5 ч. 2 ст. 557); “прикордонне переслідування” (ст. 570).

3 огляду на викладене, слід визнати, що згадане у ч. 4 ст. 96-2 поняття “переслідування”, порівняно з іншими (зазначеними) випадками його використання, має своє особливе, відмінне значення. По суті, йдеться про “кримінальне провадження - досудове розслідування і судове провадження, процесуальні дії у зв'язку із вчиненням діяння, передбаченого законом України про кримінальну відповідальність” (п. 10 ч. 1 ст. 3 КПК).

9. Відповідно до ст. 387 ЦК “власник має право витребувати своє майно від особи, яка незаконно, без відповідної правової підстави заволоділа ним”. Це означає, що безпідставне рішення про застосування спеціальної конфіскації майна

DOI (Article): https://doi.org/10.36486/np.2019.2.18

(C) Muzyka Anatolii, 2019 
власник останнього може оспорити в суді: звернутися 3 позовом до держави про витребування майна із чужого незаконного володіння.

Спеціальна конфіскація не застосовується, якщо майно: перебуває у власності добросовісного набувача (ч. 4 ст. 96-2); згідно із законом підлягає поверненню власнику (законному володільцю) або призначене для відшкодування шкоди, завданої злочином (ч. 5 ст. 96-2). Останнє положення закону, як правильно наголошується в літературі, містить корупційні ризики, оскільки вирішення питання про обсяги об'єкта спеціальної конфіскації і джерела відшкодування шкоди, завданої злочином, віддано на розсуд суду. Ухвалюючи рішення про відшкодування зазначеної шкоди саме в такий спосіб, суд одночасно позбавляє себе можливості застосувати спеціальну конфіскацію. При цьому, зрештою, можуть суттєво зменшитися майнові витрати винного, що є несправедливим. Тобто замість спеціальної конфіскації і законних витрат на відшкодування шкоди, завданої злочином, винуватий обмежиться лише останнім обов'язком, наприклад, за умовами угоди про примирення між потерпілим та підозрюваним чи обвинуваченим, або угоди між прокурором та підозрюваним чи обвинуваченим про визнання винуватості (статті 468-476 КПК).

10. Вирішення питання про спеціальну конфіскацію врегульовано ч. 9 ст. 100 КПК України. Зокрема, під час застосування цього кримінально-правового заходу насамперед має бути вирішене питання про повернення грошей, цінностей та іншого майна власнику (законному володільцю) та/або про відшкодування шкоди, завданої злочином. Спеціальна конфіскація застосовується лише після доведення в судовому порядку стороною обвинувачення, що власник (законний володілець) майна знав про його незаконне походження та/або використання. У разі відсутності у винуватого майна, на яке може бути звернене стягнення, крім майна, яке підлягає спеціальній конфіскації, збитки, завдані потерпілому, цивільному позивачу, відшкодовуються за рахунок коштів від реалізації конфіскованого майна, а частина, що залишилася, переходить у власність держави.

У разі, якщо власник (законний володілець) грошей, цінностей та іншого майна, які підшукані, виготовлені, пристосовані або використані як засоби чи знаряддя вчинення злочину та/або зберегли на собі його сліди, був встановлений після застосування спеціальної конфіскації та не знав і не міг знати про їх незаконне використання, він має право вимагати повернення належного йому майна або коштів з державного бюджету, отриманих від реалізації такого майна.

Спір про належність речей, що підлягають поверненню, вирішується у порядку цивільного судочинства. У такому випадку річ зберігається до набрання рішенням суду законної сили (пункти 10-12 частини 9 статті 100 КПК).

11. Необхідно пам'ятати, що законом передбачені певні види й обсяг майна, яке ні за яких обставин не підлягає конфіскації. Йдеться про Перелік майна, на яке не може бути звернено стягнення за виконавчими документами (додаток до Закону “Про виконавче провадження” від 2 червня 2016 р. № 1404-VIII). На підставі п. 2 розділу XIII “Прикінцеві та перехідні положення" цього Закону втратив чинність Перелік майна, що не підлягає конфіскації за судовим вироком (додаток до Кримінального кодексу України).

12. Судове рішення про застосування спеціальної конфіскації має виконуватися на підставі і в порядку, передбачених Законом “Про виконавче

DOI (Article): https://doi.org/10.36486/np.2019.2.18

(c) Muzyka Anatolii, 2019 Issue 2(44) 2019 http://naukaipravoohorona.com/ 
DOI (Issue): https://doi.org/10.36486/np.2019.2

Issue 2(4.4) 2019

провадження" (зокрема, статтями $5,26,62$ ). Під час виконання такого рішення не можуть бути застосовані статті 48, 49 КВК, оскільки вони регламентують виконання покарання у виді конфіскації майна.

Отримано 05.06.2019 
Попович Володимир Михайлович, доктор юридичних наук, професор, заслужений юрист України,

головний науковий співробітник ДНДІ МВС України, м. Київ, Україна ORCID ID 0000-0002-4538-3274

\section{МЕТОДОЛОГІЯ ТЕРМІНОЛОГІЧНО-ПОНЯТІЙНОГО ВІДОБРАЖЕННЯ КРИМІНОГЕННИХ ПРОЦЕСІВ У СФЕРІ ЕКОНОМІКИ}

У статті розробляються праксеологічні, етимологічні та методологічні основи формування термінологічно-понятійного апарату, що відображають криміногенні прочеси у сфері економіки.

Розроблено також умовні позначення понять, що відображають криміногенні процеси, криміногенний потенціал, індекс криміногенного потенціалу та формулу розрахунку індексу криміногенного потенціалу у сфері економіки.

Ключові слова: криміногенні прочеси; сфера економічних відносин; деструктивно-руйнівні, сочіально-конфліктні відносини; капітали, здобуті злочинним шляхом; фонові явища злочинності; формула розрахунку індексу криміногенного потенціалу.

\footnotetext{
Про терміни й поняття не спорять, продуктивніше домовлятись.

При цьому домовитись завжди легше, якщо термін найбільш точно відображає форму, а поняття адекватно розкриває зміст процесів, відносин, дій, подій, інших явищ, дійсності, названих терміном та визначених у змісті його поняття.
}

В.М. Попович

Процеси, відносини, дії, події, інші явища дійсності знаходяться в постійній зміні - розвиваються, деградують, застигають у певному стані, що зумовлює постійне напрацювання, уточнення, формування відповідного термінологічнопонятійного апарату, здатного відобразити ці процеси, визначити проблеми та розробити шляхи їх розв’язання. Тому розроблення чи науково-обгрунтоване уточнення термінологічно-понятійного апарату є завжди надзвичайно важливим і актуальним як для кримінологічного, так і для будь-якого іншого дослідження, спрямованого на встановлення та розв'язання проблем у тій чи іншій сфері суспільних відносин. Це стосується і криміногенних процесів у сфері економіки. Однак, незважаючи на численні дослідження злочинності у сфері економіки, в них вивчались інші проблеми протидії злочинності у сфері економіки [1 с. 1926 ]. Водночас такі поняття, як “криміногенні процесі у сфері економіки”, “злочинність у сфері економіки”, “криміногенній потенціал”, “індекс криміногенного

DOI (Article): https://doi.org/10.36486/np.2019.2.19

(c) Popovych Volodymyr, 2019 
потенціалу” та багато інших термінів і понять, що відображають структуру криміногенних процесів у сфері економіки, залишаються не розробленими. Відповідно метою нашого дослідження є об'єктивне, етимологічно і методологічно зважене, праксеологічно узгоджене формування термінологічно-понятійного апарату, покликаного найбільш повно і об’єктивно відобразити виробничо-технологічні, обліковообігові, цивільно-правові та інші аспекти капіталообороту, під виглядом якого відбувається відтворення криміногенних процесів у сфері економіки. Завданням цього дослідження є: розробка поняття криміногенні процеси, а також визначення понять, що утворюють його такі структурні складові, як: злочинність у сфері економіки, фонові явища злочинності та капітали злочинного походження, криміногенний потенціал, індекс криміногенного потенціалу у сфері економіки та низку інших понять, що відображають криміногенні процеси у сфері економіки.

Перед тим як перейти до визначення змісту поняття “криміногенні процеси у сфері економіки” та інших термінів, що відображають зміст структури, причиннонаслідкові механізми відтворення зазначених криміногенних процесів, доцільно стисло розглянути напрацьовані раніше методологічні, етимологічні та праксеологічні засади формування термінів і понять [2, с. 138-146; с. 151-160]. Слово “термін” походить від лат. (terminus) і пояснюється у тлумачному словнику як “...вираження певного поняття, якоїсь галузі науки” [3, с. 669; 4, с. 302-304]. Однак зроблений нами етимологічний аналіз співвідношення термінів і понять [2, с. 138-146; с. 151-160] дає підстави стверджувати, що термін позначає зовнішню форму явища, окреслює зовнішні ознаки конкретних предметів, процесів, відносин, дій, подій та інших явищ реальної дійсності.

Наприклад, терміни “криміногенні процеси”, “сфера економіки”, “економічний злочин”, “загальнокримінальне правопорушення”, “фонові явища злочинності у сфері економіки”, які лише іменують відповідні складові явища, що в сукупності утворюють криміногенні процеси у сфері економіки. Однак це тільки назви, вони не відображають внутрішній зміст поіменованих ними явищ, у зв’язку з чим різні фахівці їх тлумачать дуже по-різному. Термін “злочини у сфері економіки” часто ототожнюють з однією з його складових - терміном “економічні злочини”, тоді як у сфері економіки, крім економічних злочинів (привласнення (розкрадання), корупція, хабарництво (незаконні доходи) тощо, вчиняються також і загальнокримінальні правопорушення (вимагання, замовні вбивства конкурентів, фізичний тиск, рейдерське захоплення об'єктів корпоративної власності тощо [5, с. 27-42].

Повертаючись до етимологічного аналізу термінів і понять, слід відзначити, що терміни і поняття категорії взаємозалежні, співвідносяться між собою як форма і зміст. Поняття як змістовну частину терміна дуже важливо наповнити об’єктивною, предметно-значущою технологічною інформацією, яка повно, об'єктивно і адекватно відображає явища, предмети, дії, події, позначені у відповідному понятті. Як відзначалось нами у попередніх публікаціях, загальні вимоги до сформованого юридичного, у т. ч. і кримінологічного поняття, такі: це імперативне, взаємоузгоджуване, загальноприйняте у фаховому середовищі, однозначне судження, яке відображає юридично значущі предметно-технологічні ознаки явищ, предметів, дій, подій та структурно-сутнісний зміст понять, що відображають і поясняють ті чи інші ознаки явища реальної дійсності [2, с. 138-146; с. 151-160].

DOI (Article): https://doi.org/10.36486/np.2019.2.19

(C) Popovych Volodymyr, 2019 Issue 2(4.4) 2019 http://naukaipravoohorona.com/ 
Незважаючи на те, що з приводу термінів і понять часто дискутують, однак, у кінцевому підсумку домовляються. Проте досягти імперативності, взаємоузгодженості, прийнятності визначеного поняття фаховим середовищем легше тоді, коли при формуванні термінів та понять їх автори-розробники дотримуються таких загальних вимог:

- термін має найбілыш повно відповідати зовнішній формі поіменованого ним явища, охоплювати зовнішні параметри, не виходити за межі зовнішньої форми поіменованого ним процесу, явища, предмета, дії, події;

- поняття, як категорії, що відображають внутрішній зміст термінів, слід конструювати з урахуванням етимологічних, праксеологічних і методологічних вимого щодо формування поняття.

У етимологічному плані зміст поняття має відповідати формі терміна, не виходити за його межі, й одночасно адекватно відображати всі етимологічно змістовні, юридично значимі ознаки (сторони, аспекти) досліджуваного явища, предмета, дії, події позначеного у терміні. У праксеологічному плані зміст поняття слід конструювати, враховуючи: його первинне визначення, історичний розвиток і трансформацію; застереження, пояснення і узгодженість первинного значення поняття з запропонованим, новим значенням. У методологічному плані зміст поняття слід узгоджувати з методологією формування термінів. Тобто методи, методики та систему їх інтерпретації в процесі дослідження явищ та визначення понять необхідно підбирати залежно від предмета дослідження, галузево-технологічних особливостей змісту криміногенних процесів у відповідній сфері економічних відносин [2, с. 138-146; 3, с. 151-160]. Окресливши теоретичні засади розробки термінів, ми підійшли до формування поняття “криміногенні процеси у сфері економіки” й до розкриття змісту його компонентів.

Криміногенні процеси у сфері економіки - це вмотивована (сформована в суспільстві морально-психологічна жага до накопичення) протиправна поведінка учасників криміногенних процесів у сфері економіки, спрямована на перманентне продукування деструктивно-руйнівних, соціально-конфліктних, суспільно небезпечних відносин, метою яких є створення умов для розширеного відтворення: 1) капіталів протиправного походження; 2) їх живильного середовища - злочинності: 2.1) фонових явищ злочинності, 2.2) які є джерелами накопичення, акумуляції (інвестування у бізнес та вчинення нових злочинів), намивання (емісії: цінних паперів, незабезпеченої коштами безготівки під виглядом банківських розрахункових операцій), відмивання (впровадження у легальний оборот) капіталів злочинного походження; 3) їх похідного продукту - криміногенного потенціалу. Розглянемо зміст складових зазначеного поняття.

Структуроутворюючі елементи криміногенних процесів у сфері економіки це: 1) жага до накопичення капіталів, у т. ч. протиправним шляхом; 2) злочинність; 3) фонові явища злочинності. Відзначені складові криміногенних процесів у сфері економіки пов'язані детерміністичними зв'язками, взаємовпливають і взаємодіють між собою. Однак центральною складовою, що вмотивовує прагнення учасників криміногенних процесів та фонових явищ злочинності до вчинення протиправних дій, це перша складова - жага до накопичення і відтворення капіталів у будь-який спосіб, у т. ч. злочинним шляхом. Дві другі складові (злочинність і

DOI (Article): https://doi.org/10.36486/np.2019.2.19

(C) Popovych Volodymyr, 2019 
фонові явища злочинності) є похідні від першої. Тобто вони є засобами реалізації прагнення до накопичення, акумуляції, відмивання, намивання капіталів протиправного походження та започаткування нових циклів їх відтворення.

Злочинність у сфері економіки - це друга складова криміногенних процесів у сфері економіки, яка є похідною від жаги до накопичення і складається 3 сукупності: економічних злочинів; загальнокримінальних правопорушень; фонових явищ злочинності. Економічні та загальнокримінальні злочини, фонові явища злочинності вчиняються в процесі та під виглядом: легітимної економічної діяльності (виробництво, обіг, обмін, розподіл, рух товарів та послуг); виконання організаційно-регулятивних, контрольних функцій та цивільно-правових операцій. Відзначені економічні злочини є основним засобом поповнення (накопичення) капіталів злочинного походження, які стали основним каталізатором відтворення жаги до накопичення та криміногенного потенціалу, які вмотивовують і стимулюють антисоціальну поведінку учасників криміногенних процесів взагалі і у сфері економіки зокрема. [6, с. 402; 7, с. 57-64; 8, с. 114;].

Фонові явища злочинності як складова криміногенних процесів у сфері економіки - це вчинені в процесі та під виглядом легітимної економічної діяльності: 1) некриміналізовані суспільно небезпечні діяння; 2) безпідставно декриміналізовані суспільно небезпечні діяння; 3) капітали, здобуті злочинним шляхом. Водночас у кримінологічній літературі зазвичай фоновими явищами злочинності називають п'янство, наркоманію, проституцію тощо [9, с. 39; 10; 11]. Так, це складові фонових явищ злочинності, але не у сфері економіки, а лише при вчинені загальнокримінальних крадіжок, грабежів, хуліганства, побутових правопорушень тощо. Проституція, п’янство, наркоманія як дії суб'єктів споживання (відмінні від дій сутенерів, наркодилерів) мають зовсім умовне, або навіть виключне відношення до сфери економіки та їі фонових явищ злочинності.

Учасники фонових явищ злочинності, як і учасники криміногенних процесів у сфері економіки взагалі, повинні бути не лише тверезомислячими, а й мати відповідну до їх статусу освіту, місце роботи, доступ до відповідних фінансових та цивільно-правових документів, організаційно-регулятивних функцій, прав і повноважень, матеріально відповідальну чи організаційно-розпорядчу посаду, службовий статус (відповідні функції, права, обов'язки і повноваження, фіскала, керівника матеріально відповідальної особи, організатора, контролера, регулятора економічних процесів тощо). Тому учасники фонових явищ злочинності у сфері економіки тісно пов'язані з предметною сферою вчинення правопорушень - певною сферою економічної, організаційно-розпорядчої, владної чи іншою сферою людської діяльності. А збудником мотивацій до відтворення фонових явищ злочинності у сфері економіки є не п'янство чи проституція, а жага до накопичення капіталів будьяким, у тому числі й протиправним шляхом.

Капітали протиправного походження є матеріальною основою, збудником жаги до їх накопичення й основою формування криміногенного потенціалу причинно-мотиваційного комплексу детермінацій, стимулів і мотивацій до антисоціальної поведінки учасників криміногенних процесів, з метою безперервного повторення нових циклів протиправних дій для розширеного відтворення капіталів злочинного походження, а також створення умов для безпечного вчинення

DOI (Article): https://doi.org/10.36486/np.2019.2.19

(C) Popovych Volodymyr, 2019 Issue 2(44) 2019 http://naukaipravoohorona.com/ 
злочинів у сфері економіки. Звідси капітали злочинного походження мають дуалістичну (двоєдину) природу. 3 одного боку, вони є мотивом відтворення жаги до накопичення, заради якого вчиняються злочини у сфері економіки. 3 іншого, - капітали злочинного походження є на лише метою, а й засобом, матеріальною основою створення умов для безпечного їх відтворення шляхом вчинення нових злочинів. Наприклад, фінансування завуальованих лобістських дій представників законодавчої влади щодо: затримки криміналізації новоутворених суспільно небезпечних діянь або декриміналізації діянь, які не втратили суспільну небезпеку. Метою таких дій є створення умов для безпечного отримання доходів шляхом вчинення некриміналізованих чи безпідставно декриміналізованих суспільно небезпечних діянь. Своєчасно некриміналізовані та безпідставно декриміналізовані суспільно небезпечні діяння, разом із капіталами протиправного походження утворюють сукупний масив фонових явищ злочинності, які часто є не менш небезпечні, ніж злочини $[12 ; 13 ; 14 ; 15 ; 16]$.

Так, некриміналізовані суспільно небезпечні діяння у сфері економіки - це новоутворені суспільно небезпечні діяння, що виникли в результаті протиправної діяльності злочинних формувань, спрямованої на пошук нових способів та протиправних схем накопичення капіталів, криміналізація яких затримується 3 двох причин: 1) нерозуміння законодавцем рівня суспільної небезпеки технологічно складних новоутворених небезпечних діянь; 2) умисного протиправного впливу 3 боку власників капіталів злочинного походження. Затримка криміналізації та безпідставна декриміналізація діянь, що не втратили суспільну небезпеку, є часто очевидними. Скритою формою впливу є випадки, коли в склад злочину не включаються найбільш небезпечні ознаки суспільно небезпечних діянь. Наприклад, фіктивне підприємництво (ст. 205 КК України) криміналізовано як “створення чи придбання підприємств з метою прикриття незаконної або забороненої діяльності”. Тобто криміналізована лише підготовка до фіктивної діяльності, а сама фіктивна діяльність, зокрема, безтоварні (фіктивні) конвертаційні (у т. ч. експортно-імпортні транснаціональні) операції в склад цього злочину не включено. До новоутворених некриміналізованих суспільно небезпечних діянь можна віднести: 1) утворення фінансових пірамід (типу Олбі-Україна, фіктивних інвестиційнобудівельних компаній типу “Еліта-центр” тощо), де потерпають тисячі громадян, у яких вилучили і привласнили кошти під виглядом інфляції тощо; 2) "Кримінальна емісія” (“намивання” безготівки шляхом випуску в обіг незабезпечених коштами платіжних документів (незабезпечені авізо, чеки, акредитиви); 3) повторне списання: лишків зношених (пошкоджених) грошей; лишків національної валюти при їі заміні чи деномінації; лишків інших цінностей, що зберігаються на позабалансових рахунках банків; 4) безоплатна експлуатація працівників під приводом випробувального терміну при працевлаштуванні тощо [12, с. 184-220; 13, с. 45-63].

Безпідставно декриміналізовані суспільно небезпечні діяння виникають: як з причин нерозуміння суспільної небезпеки діянь, так під зловмисним впливом власників капіталів злочинного походження. При цьому порушуються такі принципи декриміналізації: 1) підвищена суспільна небезпека діянь не втрачена, а часто й наростає; 2) наявною є масовидність безпідставно декриміналізованих діянь; 3) іншими засобами (крім кримінально-правових) ці діяння зупинити не можна.

DOI (Article): https://doi.org/10.36486/np.2019.2.19

(C) Popovych Volodymyr, 2019 Issue 2(44) 2019 http://naukaipravoohorona.com/ 
Як приклад, декриміналізація статей КК України: 201 - Контрабанда (товарів); 218 - Фіктивне банкрутство; 220 - Приховування стійкої фінансової неспроможності; 221 - Незаконні дії у разі банкрутства; 223 - Порушення порядку випуску (емісії) та обігу цінних паперів; 228 - Примушування до антиконкурентних узгоджених дій. Декриміналізація інших діянь, що були безпідставно декриміналізовані за Законом України "Про гуманізацію кримінальної відповідальності...” від. 15.11. 2011 № 4025 та ін. подібні закони [14. с. 163-165; 15; 16].

Криміногенний потенціал у сфері економіки має дуалістичний характер. 3 одного боку - це похідний продукт від капіталів протиправного походження та жаги їх накопичення, спрямованих на створення сприятливих умов для безнаказаного вчинення нових злочинів як засобу розширеного відтворення капіталів протиправного походження. 3 іншого - це категорія, що відображає як статичний, так і динамічний стан криміногенних процесів у сфері економіки.

Структура криміногенного потенціалу охоплює: сукупність учинених (як виявлених, так не виявлених) зареєстрованих і незареєстрованих природно-латентних економічних злочинів та укритих від реєстрації правоохоронцями або не заявлених потерпілими штучно-латентних загальнокримінальних правопорушень, вчинених у сфері економіки, а також сукупність фонових явищ злочинності, причин, умов та динаміки відтворення злочинності й кількості осіб, що вчинили злочини у сфері економіки на певній території та за певний період часу. Поняття “криміногенний потенціал у сфері економіки”, крім відзначеного, покликане виключити некоректне використання терміна “криміналізація”, який спочатку політики, а пізніше і юристи, зокрема і кримінологи, стали використовувати не в традиційному, кримінально-правовому значенні, а як “криміналізація економіки”, “криміналізація держави”, “криміналізація суспільства” тощо [17]. Необхідно враховувати, що термін “криміналізація” вже зайнятий кримінально-правовою наукою й означає законодавче визнання діяння злочином та встановлення за його вчинення покарання. Відповідно застосовувати його нетрадиційно, без застережень у кримінологічній чи інших науках означає, що “економіка”, “держава” чи “суспільство” вже визнані законодавцем злочинними. Тому разом із кримінальноправовим поняттям “криміналізація” слід дати його кримінологічне визначення як зростання криміногенного потенціалу в тій чи іншій сфері суспільних відносин, а також розробити формулу визначення індексу криміногенного потенціалу.

Індекс криміногенного потенціалу у сфері економіки - це максимально можливе та повне визначення і врахування: 1) всіх складових фактично вчинених злочинів і фонових явищ злочинності; 2) відображення тенденцій, динаміки, кількісно-якісних показників причин, умов і мотивацій відтворення злочинності; 3) кількості осіб, що вчинили злочини у сфері економіки, стан формування політичної волі в державі щодо усунення причин та умов відтворення злочинності; 4) стан запобігання і протидії злочинам у сфері економіки, на певній території та за певний період часу.

Умовні позначення щодо виміру індексу криміногенного потенціалу (ІКП) відображає: кількісно-якісні кримінологічні показники стану та динаміки змін щодо вчинення злочинів у сфері економіки, а також стану запобігання та протидії злочинності де: СФЗ означає - сукупність фактично вчинених у сфері економіки

DOI (Article): https://doi.org/10.36486/np.2019.2.19

(C) Popovych Volodymyr, 2019 
злочинів та фонових явищ злочинності, а саме: 33 - зареєстровані злочини у Єдиному Державному Реєстрі СДР; УЗ - укриті від реєстрації злочини; ЛНЗ природно та штучно-латентні невиявлені злочини; ФЯЗ - фонові явища злочинності (некриміналізовані та безпідставно декриміналізовані, але суспільно небезпечні діяння, капітали злочинного походження); ТЗБЗ - тенденції збільшення злочинів; ТЗМЗ - тенденції зменшення злочинів; а також стан протидії злочинності, зокрема: ЗДЗ означає - загальна динаміка змін $(\%,+,-)$; КЯЗЗ та кількісноякісні зміни злочинності (ступінь тяжкості злочинів згідно зі ст. 12 КК); ГПВЗ - головні кількісно-якісні причини та умови відтворення злочинності; СУП - стан усунення причин вчинення злочинів; СРЗ - стан розкриття злочинів; ПТ - на певній території; ППЧ - та за певний період часу. Формула визначення індексу криміногенного потенціалу взагалі і у сфері економіки, зокрема, виглядає так: ІКП=ФЗ(3З+УЗ+ЛНЗ+ФЯЗ+ТЗБЗ-ТЗМЗ)+ЗДЗ+КЯЗЗ+ГПВЗ+СУП+СРЗ на ПТ за ППЧ. Формула визначення індексу криміногенного потенціалу включає як кількісно-якісні показники вчинення злочинів та фонових явищ злочинності, так і стан протидії злочинності на певній території та за певний період часу. Головною метою визначення індексу криміногенного потенціалу в сфері економіки $€$ не просто констатування показників відтворення злочинності в країні, а й: 1) привернення уваги держави та суспільства на стан відтворення, запобігання і протидії криміногенним процесам у сфері економічних відносин країни; 2) формування політичної волі в державі щодо необхідності визначати й усувати причини та умови відтворення злочинності; 3) своєчасна постановка питання щодо відновлення кримінологічних, кримінально-правових, кримінально-процесуальних та організаційно-правових механізмів, які б виключали і не допускали використання держави, її органів, у тому числі і правоохоронних структур, у корпоративних інтересах кланів; 4) забезпечення використання органів держави в суто загальнонаціональних інтересах, в інтересах суспільства, людини і громадянина - в інтересах національної безпеки країни.

\section{СПИСОК ВИКОРИСТАНИХ ДЖЕРЕЛ}

1. Кальман А.Г., Христич І.О. та ін. Злочинність у сфері економіки: проблеми, прогнозування, планування та координація заходів протидії. Х., 2005. С. 19-26; Бойко А.М. Детермінація економічної злочинності в Україні в умовах переходу до ринкової економіки: монографія. Вид. ЛНУ ім. Івана Франка, 2008. 380 с.

2. Попович B.M. Термінологія з проблем тінізації та детінізації суспільних відносин: етимологічні, праксеологічні та методологічні основи її формування. Наука і правоохорона. К.: ДНДІ МВС України, 2016. № 4, с. 138-146; Попович В.М. Праксеологічні основи формування понятійного апарату з проблем тінізації та детінізації суспільних відносин. Наука і правоохорона. К.: ДНДІ МВС України, 2017. № 2, С. 151-160.

3. Нечволод Л.І. Сучасний словник іншомовних слів. Харків: Торсінг плюс, 2007. 768 с.

4. Велика Радянська енциклопедія. 2-е вид. М., 1956. Т. 27. С. 316.

5. Попович B.M., Попович М.В. Проблеми розслідування економічних злочинів: навч. посіб. К.: Юрінком Інтер, 2016. 350 с.

6. Попович B.M. Тіньова економіка як предмет економічної кримінології: монографія. К.: Правові джерела, 1998. 447 с.

7. Попович B.M. Электронные расчеты - панацея от криминальных эмиссий или катализатор роста криминогенного потенциала в банковской системе? Бюллетень законодательства и юридической практики Украины. 1994. № 2. С. 57-64.

DOI (Article): https://doi.org/10.36486/np.2019.2.19

(C) Popovych Volodymyr, 2019 
8. Попович В.M. Економіко-кримінологічна теорія детінізації економіки: монографія. Ірпінь, НВЦ АДПСУ, 2001. 524 с.

9. Назаренко Д.О. Фонові для злочинності явища: феномен, детермінація та протидія: автореф. дис. ... д-ра юрид. наук: 12.00.08. Харків: Наукова бібліотека ХНУВС, 2014. 39 с.

10. Данишин, В.В. Голіна, М.Ю. Валуйська І.М. та ін. Кримінологія: Загальна та Особлива частини: підручник / за заг. ред. В.В. Голіни. 2-е вид. перероб. і доп. Х.: Право, 2009. 288 с. $264 \mathrm{c}$.

11. Іванов Ю.Ф., Джужа О.М. Кримінологія: навч. посіб. К.: Вид. Паливода А. В., 2006.

12. Попович B.M. Кримінологічна характеристика фіктивного підприємництва: Проблеми та перспективи протидії діяльності СПД з ознаками фіктивного підприємництва. К.: Алерта, 2012. C. $184-220$.

13. Попович B.M. Правові основи банківської справи та її захист від злочинних посягань. К.: Правові джерела, 1995. 325 с.

14. Попович B.M. Курс лекцій “Актуальні проблеми кримінального права”. К.: Юрінком Інтер, 2009. $256 \mathrm{c}$.

15. Попович B.M. Гуманізація кримінального законодавства України: проблеми, виклики та загрози. Держава і право: зб. наук. праць. Інститут Держави і права ім. Корецького. К., 2012. Вип. № 56. С. 405-410.

16. Попович В.М. Кримінологічні аспекти гуманізації кримінальної відповідальності. Наука і правоохорона. К.: ДНДІ МВС України, 2012. № 1. С. 33-41.

17. Дрьомін B.M. Інституціональна теорія злочинності та криміналізації суспільства: автореф. дис. ... д-ра юрид. наук. Одеська нац. юрид. академія. Одеса, 2010. 40 с.

\section{REFERENCES}

1. Kalman A.H., Khrystych I.O. ta in. (2005) Zlochynnist u sferi ekonomiky: problemy, prohnozuvannIa, planuvannIa ta koordynatsiIa zakhodiv protydii. "Economics crime: problems, forecasting, planning and coordination of counteraction measures". Kh. 19-26 pp.; Boyko A.M. (2008) Determinatsiia ekonomichnoi zlochynnosti v Ukraini v umovakh perekhodu do rynkovoi ekonomiky: monohrafiia. "Determination of economic crime in Ukraine in the transition to a market economy": a monograph. Kind. LNU them. Ivan Franko. 380 p. [in Ukrainian].

2. Popozych V.M. (2016) Terminolohia z problem tinizatsii ta detinizatsii suspilnykh vidnosyn: etymolohichni, prakseolohichni ta metodolohichni osnovy yii formuvannia. "Terminology on problems of shadowing and detinization of social relations: etymological, praxeological and methodological bases of its formation". Nauka I Pravookhorona. K.: SRI of the Ministry of Internal Affairs of Ukraine. № 4, p. 138-146 pp.; Popozych V.M. (2017) Prakseolohichni osnovy formuvannya ponyatiynoho aparatu z problem tinizatsiyi ta detinizatsii suspilnykh vidnosyn. "Praxeological bases of formation of conceptual apparatus on problems of shadowing and detinization of social relations". Nauka I Pravookhorona. K.: DNII Ministry of Internal Affairs of Ukraine. № 2. 151-160 pp. [in Ukrainian].

3. Nechvolod L.I. (2007) Suchasnyi slovnyk inshomovnykh sliv. "Modern dictionary of foreign words". Kharkiv: Torsing Plus. 768 p. [in Ukrainian].

4. Velyka Radianska entsyklopediia. 2-e vyd. "The Great Soviet Encyclopedia”. Iss. 2. M., 1956. Vol. 27. 316 pp. [in Ukrainian].

5. Popozych V.M., Popozych M.V. (2016) Problemy rozsliduvannia ekonomichnykh zlochyniv. "Problems of investigation of economic crimes": Educ. tool. K.: Jurinkom Inter. 350 p. [in Ukrainian].

6. Popozych V.M. (1998) Tinova ekonomika yak predmet ekonomichnoyi kryminolohii. "The shadow economy as a subject of economic criminology": a monograph. K.: Legal sources. 447 p. [in Ukrainian].

7. Popovich V.M. (1994) Elektronnyie raschety - panatseya ot kriminalnykh emissiy ili katalizator rost kriminogennogo potentsiala $\mathrm{v}$ bankovskoy sisteme? "Electronic calculations - a panacea for criminal emissions or a catalyst for the growth of criminal potential in the banking system?” Bulletin of legislation and legal practice of Ukraine. № 2. 57-64 pp. [in Russian].

8. Popozych V.M. (2001) Ekonomiko-kryminolohichna teoriia detinizatsii ekonomiky: monohrafiia. "Economic-Criminological Theory of the Shadowing of the Economy": monograph. Irpin, STCU, 524 p. [in Ukrainian].

DOI (Article): https://doi.org/10.36486/np.2019.2.19

(C) Popovych Volodymyr, 2019 Issue 2(4.4) 2019 http://naukaipravoohorona.com/ 
9. Nazarenko D.O. (2014) Fonovi dlia zlochynnosti yavyshcha: fenomen, determinatsiia ta protydiia. "Background to crime phenomenon: phenomenon, determination and counteraction": author. Dr. Jur. Sciences: 12.00.08. Kharkiv: KhNUV Scientific Library. 39 p. [in Ukrainian].

10. Danyshyn, V.V. Holina, M.Yu. Valuyska, I.M. ta in. (2009) Kryminolohiia: Zahalna ta Osoblyva chastyny: pidruchnyk. "Criminology: General and Special sections": textbook / by head. ed. V.V. Branches. Iss. 2. ext. X.: Pravo. 288 p. [in Ukrainian].

11. Ivanov Yu.F., Dzhuzha O.M. (2006) Kryminolohiia: navch. posib. "Criminology: manual". Moscow: Izd. Palyvoda A.V. 264 p. [in Ukrainian].

12. Popozych V.M. (2012) Kryminolohichna kharakterystyka fiktyvnoho pidpryyemnytstva: Problemy ta perspektyvy protydii diialnosti SPD z oznakamy fiktyvnoho pidpryiemnytstva. "Criminological Characteristics of Fictitious Entrepreneurship: Problems and Prospects for Combating SPD Activities with Fictitious Entrepreneurship Features”. K.: Alerta. 184-220pp. [in Ukrainian].

13. Popozych V.M. (1995) Pravovi osnovy bankivskoi spravy ta yii zakhyst vid zlochynnykh posyahan. "Legal basis of banking and its protection against criminal offenses. K.: Legal sources. 325 p. [in Ukrainian].

14. Popovych V.M. (2009) Kurs lektsii "Aktualni problemy kryminalnoho prava”. Lecture Course "Topical Issues in Criminal Law": Yurincom Inter, K. 256 p. [in Ukrainian].

15. Popozych V.M. (2012) Humanizatsiia kryminalnoho zakonodavstva Ukrainy: problemy, vyklyky ta zahrozy. "Humanization of Ukraine's criminal law: problems, challenges and threats". State and Law: Coll. Sciences work. Institute of State and Law Koretsky. K. Iss. No. 56. 405-410 pp. [in Ukrainian].

16. Poporych V.M. (2012) Kryminolohichni aspekty humanizatsii kryminalnoi vidpovidalnosti. "Criminological aspects of humanization of criminal responsibility. Nauka i pravookhorona. K.: State Research Institute of the Ministry of Internal Affairs of Ukraine. № 1. 33-41 pp. [in Ukrainian].

17. Dromin V.M. (2010) Instytutsionalna teoriia zlochynnosti ta kryminalizatsii suspilstva: avtoref. dys. ...d-ra yuryd. nauk. "Institutional theory of crime and criminalization of society": abstract. diss. Dr. Juridical Sciences. Odessa National Law Academy. Odessa. 40 p. [in Ukrainian].

UDC 343.37

Popovych Volodymyr, Doctor of Juridical Sciences, Professor, Honored Artist of Ukraine, Chief Researcher, State Research Institute MIA Ukraine, Kyiv, Ukraine ORCID ID 0000-0002-4538-3274

\section{METHODOLOGY OF TERMINOLOGICAL AND CONCEPTUAL REFLECTION OF CRIMINOGENIC PROCESSES IN THE SPHERE OF ECONOMY}

Development of terms and concepts reflecting criminal processes in the economic sphere is highly relevant since processes, relations, actions, events, and other realworld phenomena continuously undergo changes - they develop, degrade, freeze in a certain state. This justifies continuous efforts to elaborate terminological and conceptual apparatus capable of reflecting criminal processes in the economic sphere. Moreover, numerous studies on criminality in the economic sphere mainly focus on crime prevention issues and do not aim at distinguishing economic crimes and crimes in the economic sphere [1, 19-26 pp.]. Consequently, the objective of this study is impartial, etymologically and methodologically accurate, praxeologically well-considered development of terms and concepts aimed at the adequate reflection of productive, technological, accounting, and circulation aspects of entrepreneurial, managerial and

DOI (Article): https://doi.org/10.36486/np.2019.2.19

(C) Popovych Volodymyr, 2019 
civil law activities under the disguise of which criminal processes in the economic sphere occur. The task of this study is as follows: the development of the new or research - and practice-based adaptation of the previously developed terminological and conceptual apparatus in criminology, criminal, economic and other sciences to the contemporary situation of processes, phenomena, actions, events so it is capable of reflecting the structure and revealing the essence of criminal processes in the economic sphere.

The study has proven that criminal processes in the economic sphere are motivated (by entrenched in society moral and psychological urge for accumulation) unlawful behavior of participants of criminal processes aimed at continuous production of destructive, socially conflicting relations, unlawful relations, and creation of conditions for the secure reproduction of the following: 1) capitals of illicit origin; 2) their fertile ground - criminality, 2.1) background phenomena of criminality; 2.2) which are sources of accumulation (investing in business and committing new crimes), panning (emission: of bonds, unsecured non-cash under disguise of banking transactions), money-laundering (introduction into legal circulation) of the capitals of criminal origin, 3) their derived product - criminality potential.

That is the article defines terms and concepts which reflect structural components of the concept criminal processes in the economic sphere: 1) participants of criminal processes and background phenomena of criminality in the economic sphere (officers: of government agencies or entrepreneurial subjects as well as frauds who illegally act on behalf of above-mentioned officers); 2) structural elements of criminal processes in the economic sphere: 2.1 ) urge for accumulation of capitals; 2.2 ) criminality (economic and general criminal offenses), 2.3) background phenomena of criminality (noncriminalized or unreasonably decriminalized socially dangerous acts); 2.4) capitals of illicit origin; 3) criminal potential in the economic sphere (derived product of capitals of illicit origin) which covers: 3.1) combination of committed (registered, unregistered - natural latent economic crimes and hidden from registration artificial latent general criminal offenses); 3.2) combination of background phenomena of criminality; 3.3) reasons, conditions, and dynamics of reproduction of criminality; 3.4) number of persons who committed crimes in the economic sphere; 3.5$)$ on a certain territory; 3.6) during a certain periof of time. The article also developed concepts: criminality potential index, shorthands for its components, and the formula for calculation of criminality potential index in the economic sphere.

Keywords: criminal processes; economic relations sphere; destructive, socially dangerous relations; extended reproduction; capitals acquired by criminal means; criminality, background criminality phenomena; sources of accumulation, panning, and reproduction of capitals of criminal origin; criminality potential; criminality potential index; formula for calculation of the criminality potential index.

Отримано 07.06.2019

DOI (Article): https://doi.org/10.36486/np.2019.2.19

(C) Popovych Volodymyr, 2019 
UDC 351.741(477):343.985

\author{
Svyrydiuk Nataliia, \\ Doctor of Juridical Sciences, Docent, \\ Deputy Head of Scientific Research Laboratory, \\ State Research Institute MIA Ukraine, \\ Kyiv, Ukraine, \\ ORCID ID 0000-0001-9772-1119
}

\title{
RATIONALE OF THE CONCEPT OF ANTI-CRIMINAL INTELLIGENCE OF LAW ENFORCEMENT AGENCIES IN UKRAINE
}

The article defines that the importance of criminal intelligence is difficult to overestimate. It is essential for the implementation of law enforcement functions.

Effective counteraction to crimes, especially its organized forms, is impossible without understanding the processes that take place in the criminal environment.

Attention is drawn to the fact that today, in connection with the entry into force of the new Criminal Procedural Code of Ukraine, operational-search activities of internal affairs bodies have lost their offensive character.

Having determined this, it is clear that the perception of the need for the formation of the Concept of criminal intelligence of the internal affairs bodies of Ukraine, the development of the Law of Ukraine "On criminal intelligence" has theoretical and practical components.

Keywords: intelligence, law enforcement, anti-criminal intelligence, criminal intelligence, intelligence information, analytical intelligence information.

Statement of problem. Combat crime is always at leading place in law enforcement activity. However, the relevance of such activities' adequacy is a fairly objective understanding of crime determination, and especially in organized forms of their actings.

Analysis of recent researches and publications. Great attention has been paid to the specific scientific and applied crime issues in the economy of Ukraine as an independent state in recent years. They are considered in dissertation researches, monographs, relevant sections of textbooks and manuals, scientific articles. In different years, they became the monographic and dissertation researches' subject of many famous scientists.

Crime prevention issues were studied in the scientists' researches of: O.M.Bandurka, V.O. Glushkov, V.V. Golina, V.K. Gryshchuk, N.O. Hutorova, L.M. Davidenko, O.M. Dzhuzhi, A.E. Zhalinsky, A.P. Zakalyuk, V.M. Kutsa, O.Ye.Korystin [1], A.M. Litvak, M.I. Melnyk, P.P. Mihailenko, M.I. Panov, V.I.Shakun and other specialists. In numerous works on Criminal law and Criminology, general issues of the crime prevention theory, prevention of certain types of crime were considered. At the same time, nowadays, crime prevention activities require fundamentally new

DOI (Article): https://doi.org/10.36486/np.2019.2.20

(c) Svyrydiuk Nataliia, 2019 
approaches aimed at ensuring a reliable protection of legal rights and interests of person, society and state.

Presentation of subject of the research. The joint efforts that have been made over these decades have led to successes in the criminal prosecution of organized crime groups, and some have hoped that the threat of organized crime will be overcome. As Steeer and Richards noted, “...prosecutors and investigators who were engaged in organized crime believed that if every person from especially dangerous criminals' list would be incarcerated, then only this one would paralyze organized crime and eliminate its corruption”. It is slowly, but confidently, practitioners and theorists realized that organized crime was regenerative and that is why law enforcement agencies began to focus their efforts on sources of power and the influence of organizations..." [2].

Thus, emphasis should be placed not on the individuals who are to be punished, but on the broader aspects. Law enforcement agencies should look wider - take care not only of specific offense, but also of criminal wider schemes. In 1983, Dintino and Martine pointed out that intelligence remains the only rational means of solving organized crime issue [3].

The use of intelligence also allows law enforcement agencies to obtain long-term benefits. "In order to obtain significant results, investigations should be part of a general strategy aimed not only at punishing some persons and enterprises; investigations should be based on informed understanding of organized crime issue that must be addressed, and must take into account the long-term effects of both a specific strategy and day-to-day operations on the implementation of this strategy" [4]. Thus, we must work not only for the sake of success today, but also for the purpose of long-term obtaining and preventing crime.

Intelligence products should give impetus to the fight against organized crime; but, unfortunately, this happens rarely. As a rule, efforts aimed at fighting organized crime are reported at operational-tactical level through the secret agents' using, informers and observers (physical and electronic).

All these activities are gathering of information, and many of intelligence officers consider data collection the most important thing. However, many such units operate without analysts or trained scouts capable of analyzing this important information. The information collected may be unofficially analyzed by scouts or prosecutors, but such informal analysts are not adequately trained on acceptable analytical methods that have been developed over the past few decades.

One of the main goals for which analytical intelligence information is used in operational investigations of cases related to organized crime is to identify incomes derived from criminal activity. Such a task requires an in-depth financial research and analysis. For example, bank records' analysis of enterprises controlled by organized criminals may reveal buildings, land, cars or other property that may be confiscated by law enforcement agencies, and may also detect other crimes such as concealment of income, money laundering, theft of funds, etc.

In response to organized crime strategic intelligence provides a long-term definition of objects and potential consequences of organized crime groups in the

DOI (Article): https://doi.org/10.36486/np.2019.2.20

(C) Svyrydiuk Nataliia, 2019 
jurisdiction of law-enforcement agency. It can study the evolution (and devolution) of criminal groups, as well as the scope of their influence.

For future investigations, general strategic assessments are used to identify group members and illegal activities [5]. One of the challenges faced by counterorganized crime units in the 21-st century is the increase in the number of different criminal groups and syndicates. The efforts of law enforcement agencies to minimize the negative effects of these criminal groups are hampered by the lack of reliable information about their members and activities. Therefore, the collection, systematization, analysis and compilation of such information will provide the intelligence unit with the main information for use in investigations.

The current criminogenic situation in Ukraine is a qualitatively new phenomenon both in terms of scale of criminal manifestations and in the degree of their devastating influence on the vital activity of society, the rights and freedoms of citizens. In recent years there has been a transformation of crime in our country, an increasing organized criminal groups quantity that have a strict hierarchical structure, use the latest technical means to ensure illegal activities, and counteract law enforcement. Organized criminal groups have turned into symbiosis of the shadow economy businessmen, armed groups serving them, and corrupt civil servants of different levels. It is the weakening of state control over the situation in the country, which allows criminologists to set their tone, dictate their rules of conduct, ideology, subculture, lobby for its legal, organizational and tactical decisions of legitimate power, and actively counteract law-enforcement structures. For the organization of criminal activity, they operate considerable financial resources, which are used, in particular, for bribing civil servants, law enforcement officers, attracting specialists from different sectors to create effective mechanisms, technologies, methods and schemes of committing crimes, etc. The situation is greatly worsened in connection with the intensification of aggressive manifestations of terrorism and extremism.

According to our belief, effective counteraction to crimes, especially its organized forms, is impossible without understanding of those processes that take place in criminal environment or vice versa creating the necessary conditions for documenting the facts of illegal activity, etc. In this regard, law enforcements face the need to find out the formation and existence provisions of criminal groups, their chosen mechanisms for committing crimes, role participation in this process of each party in the criminal group, the movement of shadow and certain legal financial flows that are the basis of these groups' existence or vice versa, the subject of their criminal interests, organized crime infrastructure functioning, etc. The organization of counteraction to their criminal activity requires extraction, analytical processing and use of intelligence information obtained in the course of conducting vowels and secret actions in order to timely prevent, detect and neutralize real and potential threats to the national interests of Ukraine.

The situation is also actualized by the fact that today, in connection with the enactment of the new Criminal Procedure Code of Ukraine, operative-investigative activity of internal affairs bodies has been offensive.

The essence of the offensive, which consists in the necessity of the preventive nature of operational units'actions so that, even at the early stages of the commission

DOI (Article): https://doi.org/10.36486/np.2019.2.20

(C) Svyrydiuk Nataliia, 2019 
of intentional crimes (preparation, attempt), actual data were received about the criminal intention of a person or group of persons, there was not allowed the exaggeration of previous criminal activity in disposal crime is actually ruined. Today, since the criminal proceedings' commencement, law enforcement operational units are denied the right to initiate measures aimed at establishing and exposing the perpetrators, but only acting within the scope of instructions of investigators and prosecutors. Thus, the essential arsenal of operative-investigative activities and methods remains virtually unnecessary. In addition, the current Law of Ukraine "On Operative-Investigative Activity" loses its relevance, linking the process of implementing the rights of operational units with the provisions of the Code of Criminal Procedure. We have to state that the operative-investigative activity theory has to be substantially rethought.

A comparative analysis of modern European and world practice shows that most developed countries go through a clear division of criminal procedure and activities for obtaining, extraction, analytical processing and forecasting of crime information, some crimes and those involved in them. It is precisely such activities that can be defined as anti-criminal intelligence.

The most developed network of expansion units exists in the US police, where each police unit has its own intelligence group, which, depending on its level, consists of information and analytical unit, group of operational personnel, group of special operations, experts group, operating undercover operatives' group, external and electronic surveillance groups, and logistics teams. The general purpose of the US intelligence service is to collect operational information that would ensure effective planning and implementation of anti-crime measures. This type of reconnaissance activity is called internal intelligence. Similar units were created in French Police - the brigade of search and seizure. They take active measures to study and monitor the criminal element, penetrating into its environment. The same approach has special units' organization in Switzerland. The Hungarian police have a wealth of experience in using intelligence units in the fight against crime. It has units at its disposal of carefully constrained collaborators specially trained to work in criminal sphere. In turn, the German Criminal Police and the constitution guardianship also use "under cover" officers in the criminogenic sphere, mainly for grave and particularly serious crimes' solving.

On October 2, 2012, the Seimas of the Republic of Lithuania adopted the Law "On Criminal Investigation", which replaced the Law "On Operational and Investigative Activities". With its adoption and entry into force, the counteraction to crime in the Republic of Lithuania consists of two logical components: constant reconnaissance activities and criminal procedure.

Structurally, the Law of the Republic of Lithuania "On Criminal Investigation" consists of 24 articles:

1. Purpose of the Law;

2. Basic concepts of the Law;

3. Legal basis and principles of criminal intelligence;

4. Task of criminal intelligence;

5. Protection of the rights and freedoms of person during conducting criminal intelligence;

DOI (Article): https://doi.org/10.36486/np.2019.2.20

(c) Svyrydiuk Nataliia, 2019 
6. Rights of criminal intelligence entities;

7. Duties of criminal intelligence entities;

8. Grounds for criminal intelligence;

9. Receiving information from business entities providing electronic communications and/or services, the Central Bank of Lithuania, financial enterprises and credit institutions, as well as other legal entities;

10. Use of special means of hardware, secret inspection of postal items and documents, control of postal items and withdrawals, secret control of correspondence and other communications;

11. Secret penetration of person's dwelling, service and other premises, closed territory, vehicles;

12. Tasks performed by law enforcement agencies;

13. Imitation of criminal activity;

14. Controlled delivery;

15. Observation;

16. Assistance to persons of criminal intelligence;

17. Preparation of procedural documents used for secret/ cover-up in the course of engaging in engaged activities in relation to arrested persons;

18. Use of criminal intelligence information;

19. Financing of criminal intelligence;

20. Internal control;

21. Coordination of criminal intelligence and control of legality;

22. Government control;

23. Parliamentary control;

24. Enactment.

It should be noted that the current Law of Ukraine "On Intelligence Organs of Ukraine" does not include the law enforcement operational units to the subjects of intelligence activities. At the same time, in accordance with the Law of Ukraine "On Operational Investigative Activity", "operative-investigative activity is a system of active and secret search, reconnaissance and counter-intelligence activities carried out with the use of operative and operational-technical means". This Law establishes an exhaustive list of state bodies that have been granted the right to carry out operativeinvestigative activities. In our opinion, a logical-semantic analysis of the provisions of the said Law, gives grounds for asserting that certain entities, in particular, internal affairs bodies, are granted the right to realize intelligence function.

In addition, Art. 1 of the Law of Ukraine "On Operative-Investigative Activity" stipulates that the tasks of operative-investigative activity are to search and fix facts on unlawful acts of individuals and groups, responsibility for which is provided for in the Criminal Code of Ukraine, intelligence and subversive activities of special services of foreign states and organizations in order to stop the offenses and in the interests of criminal justice, as well as obtain information in the interests of citizens, society and state security. Consequently, the legislator emphasizes the information nature of operative-investigative activity, which constitutes the essence of intelligence activities.

DOI (Article): https://doi.org/10.36486/np.2019.2.20

(c) Svyrydiuk Nataliia, 2019 
Intelligence operations of law enforcement operational units are carried out in the following areas - personal intelligence, agent intelligence, technical intelligence, analytical intelligence. In the system of the Ministry of Internal Affairs of Ukraine, intelligence functions are performed by units of the Department of Criminal Investigation, Department of Operations and Operations Department. In addition, at the tactical level, reconnaissance activities are inherent in other law enforcement operational units in terms of work. At the same time, it is etymologically correct, in our opinion, to speak about "criminal" intelligence, which emphasizes its essence and direction in combating crime.

Based on the foregoing, we believe that today it is reasonable to develop a Concept of criminal intelligence of the bodies of internal affairs of Ukraine, which should structurally consist of:

1. General provisions (statement of problem);

2. Definition of basic concepts and categories (thesaurus of concept);

3. The state of legal regulation;

4. General characteristics of the object (crime) and development forecast;

5. Purpose, task and mechanism of the concept implementation;

6. The main ways and directions of the concept implementation;

7. Information, scientific, personnel, material and technical and financial support, etc.

The Concept purpose should be to determine the legal, organizational and tactical foundations of criminal intelligence of the bodies of internal affairs of Ukraine in order to protect individuals, state and society from crime. The elaboration of this Concept will ensure the legal basis creation for the operational units of the Ukrainian law enforcement agencies that carry out intelligence activities in the interests of criminal justice and will ensure that information security actors in Ukraine are informed of the intelligence necessary for prompt adoption of management decisions in the field of combating crime.

An obligatory element of this Concept is the drafting of the Law of Ukraine "On Criminal Investigation", introducing the relevant amendments and additions to the current legislation of Ukraine, in particular, the Criminal Procedure Code, the Laws of Ukraine "On Intelligence Authorities of Ukraine", "On the Militia", departmental normative acts, etc.

It should be emphasized that the bill should define the purpose and tasks of the criminal intelligence of law enforcements, grounds for its implementation, its legal basis and principles. It establishes the state authorities that carry out criminal investigation, these units' authorities, order of providing intelligence information and protection of criminal intelligence information, specified bill, among other things, should contain an exhaustive list of reconnaissance measures (without disclosing the tactics of their conduct). It also defines the procedure for financing and logistics, social and legal guarantees of employees of bodies and units that carry out criminal investigations and persons conducive to its implementation, guarantees of observance of legality, especially the control over the implementation of criminal intelligence, and the peculiarities of control and supervision.

DOI (Article): https://doi.org/10.36486/np.2019.2.20

(c) Svyrydiuk Nataliia, 2019 
It is believed that the perception of the necessity of forming the Concept of criminal intelligence of the bodies of internal affairs of Ukraine, the drafting of the Law of Ukraine "On Criminal Investigation" has theoretical and practical components.

First, it will promote further scientific research in the field of combat crime and revision of paradigm of operational and investigative activities.

Secondly, it will turn off the offensive, pre-emptive nature of the operational units of the internal affairs bodies in the strategic and tactical directions of combating crime.

Thirdly, it will provide a comprehensive, continuous supply of intelligence information in order to fulfill the tasks of criminal justice.

We believe that the directions of this Concept are fully in line with the directions of reforming the bodies of internal affairs of Ukraine and their legal support, the European integration course of our state.

Conclusions. The value of criminal intelligence is difficult to overestimate. It is essential for the enforcement of the law enforcement function. We must further promote its "scientific" approach, realizing, of course, that it is art that requires great analytical abilities to convert raw data into a finished product, and this product is called intelligence information. To initiate an intelligence process, you must have a criminal predicate. Perhaps even more important is the recognition that the ability to set the level of a criminal threat is of utmost importance in order to ensure that there is neither excessive nor insufficient, but a well-considered response. It is the question of threat level that seems to have led to the use of intelligence and misuse of intelligence in the history of the United States. The same reaction deserves not all criminal threats.

Accordingly, the establishment of real and fleeting or transitional threats is an art that can only be realized through careful analysis and long experience and deep knowledge.

\section{REFERENCES}

1. Anti-money laundering: international standards, foreign experience, administrative law, criminological, criminal law, criminalistic framework and financial monitoring system in Ukraine. Textbook. Ed. Korystin O. There. Kyiv: SKIF, 2015. 984 p.

2. Stier, Edwin and Peter Richards (1986) "Strategic Decision Making in Organized Crime Control; The need for a Broadened Perspective", Major Issues in Organized Crime Control. Washington, DC: National Institute of Justice.

3. Dintino, Justin and Frederick T-Martens. (1983) Police Intelligence Systems in Crime Control. Springfield, IL.

4. Goldstock, Ronald (1986) "Operational Issues in Organized Crime Control" Major Issues in Organized Crime Control. Washington DC: National Institute of Justice.

5. Peterson, Marilyn B. (1994) "Intelligence and Analysis within the Organized Crime Function" Handbook of Organized Crime in the United States, Robert J. Kelly, Ko-Lin Chin and Rufus Schatzberg, editors. Westport, CT: Greenwood Press.

DOI (Article): https://doi.org/10.36486/np.2019.2.20

(c) Svyrydiuk Nataliia, 2019 
УДК 351.741 (477):343.985

Свиридюк Наталія Петрівна, доктор юридичних наук, доцент, заступник завідувача науково-дослідної лабораторії ДНДІ МВС України, м. Київ, Україна

ORCID ID 0000-0001-9772-1119

\section{ОБГРУНТУВАННЯ КОНЦЕПЦІЇ АНТИКРИМІНАЛЬНОЇ РОЗВІДКИ ПРАВООХОРОННИХ ОРГАНІВ В УКРАЇНІ}

У статті доведено, що значення кримінальної розвідки переоцінити важко. Вона є суттєво важливою для виконання правоохоронної функції.

Ефективна протидія злочинам, особливо іï організованим формам, неможлива без розуміння тих процесів, які відбуваються у злочинному середовищі.

Акцентовано увагу, що сьогодні, у зв'язку з набранням чинності новим Кримінальним процесуальним кодексом України, оперативно-розшукова діяльність правоохоронних органів України втратила наступальний характер.

Компаративний аналіз сучасної європейської та світової практики засвідчує, що більшість розвинених країн рухаються шляхом чіткого розгалуження кримінально-процесуальної діяльності та діяльності з отримання, добування, аналітичного оброблення та прогнозування інформації про злочинність, окремі злочини та осіб, що до них причетні. Саме таку діяльність можна визначити, як антикримінальну розвідку.

Акцентовано, що на сьогодні обгрунтованим є розроблення Концепції кримінальної розвідки правоохоронних органів України. Розроблення цієї Концепції забезпечить створення правових основ діяльності оперативних підрозділів правоохоронних органів України, які здійснюють розвідувальну діяльність в інтересах кримінального судочинства та забезпечать інформування суб'єктів забезпечення національної безпеки України розвідувальною інформацією, необхідною для оперативного прийняття виважених управлінських рішень у сфері протидії злочинності.

Напрями означеної Концепції повною мірою збігаються з напрямами реформування правоохоронних органів України та їх правового забезпечення, Свроінтеграційним курсом нашої держави.

Наголошено, що законопроект “Про кримінальну розвідку” має визначати мету і завдання кримінальної розвідки правоохоронних органів, підстави для іï здійснення, її правову основу та принципи.

Вбачається, що сприйняття необхідності формування Концепції кримінальної розвідки правоохоронних органів України, розроблення Закону України “Про кримінальну розвідку” мають теоретичну та практичну складові.

Ключові слова: розвідка, правоохоронні органи, антикримінальна розвідка, кримінальна розвідка, розвідувальна інформація, аналітична розвідувальна інформація.

Отримано 06.06.2019

DOI (Article): https://doi.org/10.36486/np.2019.2.20

(c) Svyrydiuk Nataliia, 2019

Issue 2(44) 2019

http://naukaipravoohorona.com/ 
Федотова Ганна Валеріївна, доктор юридичних наук, старший науковий співробітник. начальник відділу ДНДІ МВС України, м. Київ, Україна,

ORCID ID 0000-0002-7798-3143 Лісниченко Лілія Василівна, науковий співробітник ДНДІ МВС України, м. Київ, Україна, ORCID ID 0000-0003-2211-741X

\section{СТАН НАУКОВО-ТЕОРЕТИЧНОЇ РОЗРОБЛЕНОСТІ ПРОБЛЕМ ЗАПОБІГАННЯ ГРАБЕЖАМ ТА РОЗБІЙНИМ НАПАДАМ}

У статті в цілому проаналізовано науково-теоретичні дослідження, присвячені питанням запобігання злочинності, зокрема особлива увага приділена таким видам корисливо-насильнищьких злочинів, як грабіж та розбій. Констатовано, що підходи до розроблення системи захисту кримінологічними засобами конституційних прав і свобод людини і громадянина від злочинних посягань обіймають важливе місце серед об'єктів кримінологічних досліджень. Викладено систематизачію наявних теоретико-правових та науково-прикладних підходів до вирішення проблем протидї грабежам $і$ розбоям. Відзначено, що перешкоджання грабежам та розбоям на сучасному етапі потребує впровадження оновлених методів щодо запобігання злочинності, спрямованих на неухильне дотримання пріоритету прав і свобод людини та громадянина, служіння держави інтересам людини.

Ключові слова: кримінально-правовий аналіз, запобігання злочинності, злочинність, корисливо-насильнищькі злочини, грабіж, розбій.

3 давніх часів свого існування людство усвідомило, що утримати та запобігти злочинності тільки шляхом суворого покарання неможливо, оскільки покарання дуже часто приносить більше зла, ніж сам злочин.

Кримінальне покарання має за мету не тільки кару за злочин, а й виправлення злочинців, тим самим запобігаючи вчиненню нових злочинів з їх боку та впливаючи на інших нестійких членів суспільства. Ідея запобігання злочинності уперше була висловлена у роботах стародавніх філософів Платона і Аристотеля. На їх думку, у суспільстві має діяти досконале законодавство, яке б відвертало людей від вчинення злочинів. Подібний напрям розвивали й просвітники XVIII ст., зокрема Т. Мор, Ж. Ж. Руссо, І. Бентам, Ш. Монтеск'є, Вольтер, Ч. Беккаріа та ін. Вони вважали, що право могло би стати могутнім засобом вирішення виникаючих у суспільстві конфліктів, і запропонували створення правової держави, серед пріоритетних завдань якої було б запобігання злочинності.

На сьогодні формування ефективної системи протидії злочинності є однією з найважливіших правоохоронних функцій державної політики України. Розроб-

DOI (Article): https://doi.org/10.36486/np.2019.2.21

(C) Fedotova Hanna, Lisnychenko Liliia, 2019 Issue 2(44) 2019 http://naukaipravoohorona.com/ 
лення системи захисту кримінологічними засобами конституційних прав і свобод людини і громадянина від злочинних посягань обіймає важливе місце серед об’єктів кримінологічних досліджень. Так, вивчення питання протидії злочинності, передусім, передбачає з'ясування сутності злочинності як явища, виявлення його внутрішніх взаємозв'язків залежно від зовнішніх чинників, важливим є її оцінка і навіть вимірювання у певних кількісних і якісних показниках. При характеристиці злочинності, описі найбільш вагомих її властивостей, що відрізняють це явище від інших негативних явищ масового характеру, зазвичай опрацьовуються її показники, до яких відносять: рівень злочинності, її коефіцієнти, структуру, динаміку, географію та “ціну”. Названі показники надають можливість розкрити соціальнокримінальний, системний і статистичний зміст злочинності. Крім того, за умовними критеріями при здійсненні кримінологічної характеристики окремих злочинних проявів відбувається класифікація за категоріями злочинів на групи. Наукові підходи серед таких критеріїв називають: найбільшу поширеність злочинних посягань на практиці; спрямованість заходів запобігання до окремої групи злочинів; угруповання злочинів за комплексним підходом (за об'єктом злочинних посягань, соціальною сферою діяльності, причинами, мотивацією, способом вчинення злочину). Саме за цими критеріями в кримінології, у структурі злочинності, виділено групу корисливо-насильницьких злочинів, до якої належать грабежі та розбійні напади.

У різні історичні періоди важливість суспільних відносини, на які посягають корисливо-насильницькі злочини і їх небезпека, спонукали дослідників до пошуків нових наукових ідей шляхом проведення теоретичних розробок. Проблемні аспекти протидії корисливо-насильницьким злочинам вивчала низка науковців - фахівців у галузі кримінології, кримінального права, криміналістики, кримінального процесу тощо. Дослідження поняття і змісту запобігання корисливо-насильницьким злочинам грунтується на наукових доробках радянських, українських та зарубіжних учених. Аналіз їх наукових доробків свідчить про значний внесок у формування напрямів протидії цим злочинам.

Дослідженню корисливо-насильницьких злочинів присвячені праці видатних зарубіжних і вітчизняних учених: С.В. Албула, Ю.М. Антоняна, В.В. Батиргареєвої, С.В. Бородіна, В.В. Василевича, В.В. Голіна, Б.М. Головкіна, І.М. Даньшина, О.М. Джужі, А.І. Долгової, Ю.Ф. Іванова, В.І. Задорожного, А.П. Закалюка, А.Ф. Зелінського, М.Г. Колодяжного, В.М. Кудрявцева, Н.В. Кулакова, С.В. Нікітенка, Д.В. Петрова, Д.В. Рівмана, В.В. Тіщенка В.І. Шакуна, Н.В. Яницької та ін.

У пошуку і визначенні найбільш ефективних шляхів, засобів і методів боротьби з корисливо-насильницькими злочинами вчені працювали над розробками щодо протистояння кримінальній експансії, подолання злочинного тиску, напрацьовували на основі реалістичної, виваженої оцінки обстановки, закономірностей, можливостей і тенденцій суспільного розвитку стратегію приборкання цього негативного соціального явища.

Так, Б.М. Головкін, розглядаючи феномен, детермінацію та напрями запобігання корисливої насильницької злочинності в Україні, здійснюючи кримінологічний аналіз злочинів проти власності, називав найпоширеніші корисливі насильницькі злочини - насильницький грабіж та розбій, що й спонукало вченого до-

DOI (Article): https://doi.org/10.36486/np.2019.2.21 Issue 2(44) 2019 http://naukaipravoohorona.com/ 
кладно розглядати кримінологічну характеристику саме цих посягань проти власності [1].

В.В. Батиргареєва проводила комплексне кримінологічне вивчення розбою, поєднаного з проникненням у житло, яке включало аналіз кількісних і якісних параметрів цього різновиду корисливо-насильницької злочинності, детермінант, що її зумовлюють, особистості розбійника і особистості потерпілого, розробку науково обгрунтованих рекомендацій по вдосконаленню практики боротьби 3 розбоями, поєднаними з проникненням у житло громадян [2].

В.В. Василевич вивчав питання боротьби з озброєними формами організованої злочинності корисливо-насильницького спрямування. Вченим сформульована дефініція поняття, а також зроблена класифікація озброєних форм організованої злочинності корисливо-насильницького спрямування, досліджена їх суспільна небезпечність, з'ясовуються причини й умови, що сприяють вчиненню злочинів організованими групами, вказуються головні напрями та заходи запобігання [3].

С.В. Албул досліджував комплекс питань щодо етіологічних, феноменологічних особливостей та закономірностей корисливо-насильницьких злочинів відносно іноземців в Україні. Він вивчав природу, закономірності й особливості віктимізації та віктимності іноземців в Україні. Науковцем детально роз'яснено комплекс питань теоретичного і практичного характеру, пов'язаних із розробкою організаційно-правових заходів боротьби зі злочинністю стосовно іноземців, подано кримінологічну характеристику корисливо-насильницьких злочинів щодо іноземних громадян в Україні, розкрито їх чинники, рівні, структуру та географію, викладено аналіз стану латентності, а також розкрито відомості щодо особи злочинця та жертви злочину.

Значну увагу С.В. Албул приділяв кримінологічній характеристиці корисливонасильницьких злочинів відносно іноземних громадян задля удосконалення наявних та розроблення нових підходів до питання профілактики корисливо-насильницьких зазіхань відносно іноземних громадян, задля їх мінімізації та поширення соціального контролю над злочинністю [4].

С.В. Нікітенко вивчав кримінологічну природу корисливої і корисливонасильницької злочинності серед жінок на тлі наркоманії, а також організацією попередження таких видів жіночої злочинності шляхом загальних та спеціальних заходів ії превенції, медико-юридичних заходів профілактики наркоманії серед жінок. Вчений розглядав вплив особистісних змін і одержаних характерологічних особливостей у результаті наркотизації умов життя і виховання, гостроти хворобливих проявів, тяжкості різних видів наркоманії на злочинну поведінку хворих на наркоманію взагалі, і жінок зокрема [5].

Н.В. Яницька розглядала групову корисливо-насильницьку злочинність молоді та питання iï попередження, розкриваючи кримінально-правові ознаки групових корисливо-насильницьких злочинів та вивчаючи загальносоціальні, спеціально-кримінологічні та віктимологічні аспекти протидії груповій злочинній поведінці молоді [6].

Д.В. Петров приділяв увагу кримінологічній характеристиці та запобіганню грабежам і розбоям, що вчиняються неповнолітніми у громадських місцях, здійснюючи загальну кримінологічну характеристику цих груп злочинів, аналізуючи

DOI (Article): https://doi.org/10.36486/np.2019.2.21

(C) Fedotova Hanna, Lisnychenko Liliia, 2019 Issue 2(44) 2019 http://naukaipravoohorona.com/ 
основні показники їх рівня, структури та динаміки, висвітлюючи характерні риси й особливості формування особистості неповнолітнього грабіжника i розбійника. Зокрема, вчений детально досліджував такі фактори, як: криміналізація молодіжного середовища, недоліки діяльності правоохоронних органів та вплив конкретної життєвої ситуації й віктимної поведінки потерпілих на виникнення і реалізацію умислу в неповнолітнього щодо заволодіння чужим майном шляхом грабежу чи розбою [7].

Особливої уваги заслуговує комплекс наукових праць вчених-кримінологів: професора В. В. Тіщенка: "Криміналістична характеристика корисливо-насильницької злочинної діяльності”, “Правові та організаційні можливості використання відомостей, отриманих в ході оперативно-розшукових заходів, для розкриття корисливо-насильницьких злочинів”, “Механізм вчинення корисливо-насильницьких злочинів”, “Корисливо-насильницькі злочини: криміналістичний аналіз” та дисертації на здобуття наукового ступеня доктора юридичних наук "Концептуальні основи розслідування корисливо-насильницьких злочинів”, у яких вчений досліджує криміналістичні аспекти класифікації та характеристики корисливо-насильницьких злочинів, розглядає програми їх розслідування в типових слідчих ситуаціях [8].

А також дисертаційне дослідження А.В. Півня "Кримінологічна характеристика та профілактика вуличної насильницької злочинності”, в якому розглядаються заходи профілактики вуличної насильницької злочинності, виокремлюються іï ознаки та особливості, здійснюється довгостроковий кримінологічний аналіз такого виду злочинності, визначаються найбільш вагомі чинники, що зумовлюють та сприяють вчиненню злочинів цієї категорії, з'ясовуються основні напрями профілактики вуличної насильницької злочинності, пропонується комплекс загальносоціальних, спеціально-кримінологічних та віктимологічних заходів, обгрунтовуються практичні пропозиції та рекомендації, спрямовані на вдосконалення профілактичної діяльності правоохоронних органів. Такі злочини, як грабіж, поєднаний із насильством (ч. 2, ст. 186 КК України), розбій (ст. 187 КК України) віднесено до системи вуличної насильницької злочинності [9].

Значний внесок у вирішення проблем кримінально-правової характеристики грабежу і розбою у межах виконання наукових досліджень зробили видатні вчені: Г.М. Борзенков, Л.Д. Владимиров, В.А. Гаухман, Є.Б. Галкін, П.І. Гришаєв, О.І. Гуров, М.Д. Дурманов, В.П. Смельянов, М.Й. Коржанський, Г.О. Кригер, Б.А. Курінов, Ю.О. Ляпунов, П.С. Матишевський, В.О. Навроцький, Б.С. Никифоров, А.О. Пінаєв, О.О. Піонтковський, С.В. Познишев та інші.

За останні роки кримінально-правова характеристика грабежу та розбою стала об’єктом пошуків у межах кандидатських дисертацій Ж.Б. Хчояна “Кримінальна відповідальність за розбій за правом України та Італії (Київ, 2006), О.О. Горішного “Кримінально-правова характеристика розбою” (Харків, 2010), I.I. Гуня "Кримінально-правова характеристика насильницьких злочинів проти власності” (Харків, 2012), М.В. Карп’юк “Насильницькі злочини проти власності за кримінальним правом України та Республіки Польща: порівняльний аспект" (Львів, 2016), А.П Рублевського “Кримінальна відповідальність за розбій” (Одеса, $2005)$ та деяких інших вчених. У порівняльному аспекті із зарубіжним законодавством зазначену проблематику досліджували такі вчені, як: М.I. Хавронюк (2007),

DOI (Article): https://doi.org/10.36486/np.2019.2.21

( ) Fedotova Hanna, Lisnychenko Liliia, 2019 Issue 2(4.4) 2019 http://naukaipravoohorona.com/ 
А.В. Савченко (2008), Ю.А. Дорохіна (2017), К.В. Паламарчук (2017), А.М. Соловйова (2019).

Вагомими серед робіт, у яких науковому аналізу піддавались питання тактикорозслідувальних засад корисливо-насильницьких злочинів, слід назвати дослідження, підготовлені вченими-криміналістами та процесуалістами, такими як: Ю.А. Кричун "Основи виявлення та розслідування корисливо-насильницьких злочинів” [10], А.В. Хірсін “Криміналістичне забезпечення розслідування корисливо-насильницької організованої злочинної діяльності” [11] та Г.В. Щербакова “Початковий етап розслідування розбоїв, вчинених з метою заволодіння приватним майном громадян” [12], Б.Ю. Бистрицький “Розслідування грабежів, учинених неповнолітніми” [13], І.Л. Калімбета “Розслідування групових корисливо-насильницьких злочинів неповнолітніх” [14], В.П. Колонюк “Розслідування розкрадання грошових засобів і цінних паперів в ощадних банках, які вчиняються шляхом крадіжки, грабежу, розбою” [15], П.Ю. Кравчук “Використання спеціальних знань під час розслідування грабежів і розбоїв” [16], А.А. Патик “Взаємодія слідчих та оперативно-розшукових підрозділів при розкритті та розслідуванні майнових злочинів” [17], Г.О. Чорний “Методика розслідування розбоїв з проникненням у житло" [18] та ін.

До робіт, підготовлених за радянські часи, які становлять теоретичну цінність і можуть визначатись базовим підгрунтям для порівняльного аналізу при вирішенні сучасних проблем запобігання та протидії корисливо-насильницьким злочинам, належать праці В.А. Владимирова і В.И. Холостова “Відповідальність за грабежі та особа грабіжника” (1976) [20], В.А. Пашковського “Проблеми боротьби з крадіжками, грабежами та розбоями” (1980) [21] та інші.

Здобутки вчених-кримінологів пострадянських країн представлені низкою робіт, присвячених як запобіганню грабежам і розбоям, так і корисливо-насильницьким злочинам. Зокрема в своїй роботі "Корыстно-насильственные преступления и их причины в республиках Северного Кавказа” А.М. Цалієв характеризував антисоціальну спрямованість дорослих корисливо-насильницьких злочинців, провів їх морально-психологічну характеристику та запропонував типологію особистості злочинця [22, с. 52-87].

Предметом дослідження В.І. Литвинова в праці “Корыстные посягательства на личную собственность и их предупреждение” стали корисливі посягання на особисту власність, автором використано особистісний підхід у вивченні корисливих посягань. Визначено види корисних злочинів проти особистої власності. Проведено кримінологічну характеристику учасників корисних посягань на особисту власність. Досліджено причини и умови, що сприяють вчиненню цих злочинних дій. Розкрито чинники, детермінуючі появу корисної злочинної орієнтації, особливості прояву корисної орієнтації при вчиненні злочинних посягань на особисту власність, особливості особи та типологію учасників злочинів з корисною орієнтацією. Запропоновано заходи загальносоціального і спеціального попередження, розроблено рекомендації з удосконалення діяльності правоохоронних органів [23].

А.А. Курашвілі в роботі “Криминологические проблемы борьбы органов внутренних дел с грабежами и разбоями” розглянув питання кримінально-

DOI (Article): https://doi.org/10.36486/np.2019.2.21

(C) Fedotova Hanna, Lisnychenko Liliia, 2019 Issue 2(44) 2019 http://naukaipravoohorona.com/ 
правового аналізу групових грабежів та розбоїв і їх кримінологічні особливості (характеристику особи злочинця, особи потерпілого, факторів, які впливають на вчинення групових грабежів і розбоїв), приділив увагу основним напрямам и особливостям попередження групових корисно-насильницьких злочинів органами внутрішніх справ [24].

Також слід згадати роботу Е. О. Алауханова “Криминологические проблемы предупреждения корыстно-насильственных преступлений”. У ній пропонується комплексна кримінологічна характеристика корисливо-насильницьких злочинів, досліджуються причини та умови, що сприяють їх вчиненню, містяться рекомендації з попередження корисливо-насильницьких злочинів у Республіці Казахстан та країнах СНД у цілому [25, с. 6-170].

B.I. Коваленко у дисертації "Криминологическая характеристика современных грабежей и разбоев и меры их предупреждения” визначаються розвиток кримінального законодавства про грабежі та розбої, поняття і ознаки сучасних грабежів та розбоїв, кримінологічна характеристика грабежів і розбоїв і проблеми їх кваліфікації, кримінологічна характеристика і типологія особи грабіжника і розбійника, взаємодія з особою потерпілого, причини грабежів і розбоїв, засоби їх попередження [26].

M.I. Прохорова у роботі “Предупреждение грабежей и разбоев” дослідила питання кримінально-правової і кримінологічної характеристики, причинного комплексу грабежів і розбоїв, механізму детермінації вчинення грабежів і розбоїв та основні шляхи попередження грабежів та розбоїв органами внутрішніх справ [27].

Широкий спектр монографічних досліджень українських авторів присвячений різній категорії суб’єктів запобігання та протидії злочинності. Зокрема, Албул С.В., Демедюк Т.С., Користін О.Є. у роботі “Протидія кримінальним правопорушенням підрозділами карного розшуку МВС України” розкрили питання здійснення оперативного обслуговування підрозділами Національної поліції та сформулювали визначення цієї категорії, як комплексу гласних і негласних заходів із забезпечення безперервного отримання інформації про стан оперативної обстановки з метою своєчасного виявлення, попередження, припинення, розкриття кримінальних правопорушень, розшуку злочинців та безвісно зниклих осіб [28]. Монографію "Громадськість у запобіганні і протидії злочинності: вітчизняний та міжнародний досвід” за загальною редакцією В.В. Голіни, М.Г. Колодяжного, С.С. Шрамко та ін. присвячено комплексному дослідженню теоретичних й прикладних проблем участі громадськості у запобіганні злочинності. У роботі розглядається вітчизняний та міжнародний досвід залучення громадськості до сфери запобігання злочинності. Зокрема надається теоретичне уявлення громадськості та ролі, яку вона відіграє у сфері запобігання злочинності; визначається місце громадськості у здійсненні кримінологічної політики України.

Викладена систематизація наявних теоретико-правових та науково-прикладних підходів до вирішення проблем протидії грабежам та розбоям покликана забезпечити всебічність, логічність та системність при формуванні концептуального плану з удосконалення методів і засобів запобігання цих злочинів, важливих і необхідних як у теоретичному, так і в прикладному значенні.

DOI (Article): https://doi.org/10.36486/np.2019.2.21

(C) Fedotova Hanna, Lisnychenko Liliia, 2019

Issue 2(4.4) 2019

http://naukaipravoohorona.com/ 
Незважаючи на значну кількість досліджень проблем попередження, розкриття та розслідування грабежів і розбоїв, більшість із них були виконані за часів існування СРСР, на території Російської Федерації чи пострадянських держав. Враховуючи ситуацію, що склалась в Україні за останні часи, зокрема, тривалої економічної, політичної, фінансової кризи, більшість робіт набули значення лише теоретичної цінності як вихідні науково-теоретичні основи та підгрунтя до подальшого удосконалення правових засад, покликаних запобігати грабежам і розбоям.

Поширення глобалізаційних процесів спонукає до визнання пріоритетами зовнішньої політики України входження в європейський політичний, інформаційний, економічний і правовий простір. 3 метою забезпечення належного виконання зобов’язань нашої держави, які випливають із членства в Раді Свропи, і досягнення набуття членства в Європейському Союзі, актуальним є вжиття необхідних заходів для конвергенції українських правових норм до європейських стандартів. Відповідно, перешкоджання грабежам та розбоям на сучасному етапі потребує впровадження оновлених методів до сфери запобігання злочинності, зокрема, неухильне дотримання пріоритету прав і свобод людини та громадянина, служіння держави інтересам людини.

В цілому розвиток суспільних відносин і зміцнення ролі держави потребує нового доктринального підходу до забезпечення безпеки людини, а це, зі свого боку, зумовлює концептуальний перегляд наявних законодавчо закріплених положень щодо регламентації понять “розбій” і “грабіж”, а також форм, методів і засобів запобігання скоєння цих злочинів.

\section{СПИСОК ВИКОРИСТАНИХ ДЖЕРЕЛ}

1. Головкін Б.М. Теоретичні та прикладні проблеми детермінації і запобігання корисливій насильницькій злочинності в Україні: автореф. дис. ... д-ра юрид. наук: спец. 12.00.08 “Кримінальне право та кримінологія; кримінально-виконавче право”. Х.: Нац. ун-т “Юридична академія України імені Ярослава Мудрого”, 2011. 37 с.

2. Батиргареєва В.С. Кримінологічна характеристика та попередження розбоїв, поєднаних 3 проникненням у житло: автореф. дис. ... канд. юрид. наук: спец. 12.00.08 "Кримінальне право та кримінологія; кримінально-виконавче право”. Х., 2002. 20 с.

3. Василевич В.В. Боротьба з озброєними формами організованої злочинності корисливогонасильницького спрямування: автореф. дис. ... канд. юрид. наук: 12.00.08. К.: НАВСУ, 1998. 18 с.

4. Албул С.В. Кримінологічна характеристика корисливо-насильницьких злочинів відносно іноземних громадян: автореф. дис. ... канд. юрид. наук: 12.00 .08 "Кримінальне право та кримінологія; кримінально-виконавче право”. Одеса, Нац. ун-т “Одеська юридична академія”. 2005. 20 с.

5. Нікітенко C.B. Профілактика корисливих та корисливо-насильницьких злочинів, скоєних жінками на тлі наркоманії: дис. ... канд. юрид. наук: 12.00.08. “Кримінальне право та кримінологія; кримінально-виконавче право”. Х.: ХНУВС, 2004. 214 с.

6. Яницька Н.В. Групова корисливо-насильницька злочинність молоді і її попередження: автореф. дис. ... канд. юрид. наук: 12.00.08. "Кримінальне право та кримінологія; кримінальновиконавче право”. К., 2000. 20 с.

7. Петров Д.В. Кримінологічна характеристика та запобігання грабежам і розбоям, що вчиняються неповнолітніми у громадських місцях: дис. ... канд. юрид. наук: 12.00.08. “Кримінальне право та кримінологія; кримінально-виконавче право”. К.: Національна академія прокуратури України, 2015. 255 с.

8. Тищенко B.B. Корыстно-насильственные преступления: криминалистический анализ. Одесса: Юрид. литература, 2002. 360 с.; Тищенко В.В. Концептуальные основы расследования

DOI (Article): https://doi.org/10.36486/np.2019.2.21

(c) Fedotova Hanna, Lisnychenko Liliia, 2019 Issue 2(44) 2019 http://naukaipravoohorona.com/ 
корыстно-насильственных преступлений: дис. ... д-ра юрид. наук: 12.00.08. Х.: НЮАУ им. Ярослава Мудрого, 2001. 445 с.

9. Півень А.В. Кримінологічна характеристика та профілактика вуличної насильницької злочинності: автореф. дис. ... канд. юрид. наук: 12.00.08. Нац. акад. внутр. справ. К., 2013.18 с.

10. Кричун Ю.А. Основи виявлення та розслідування корисливо-насильницьких злочинів: автореф. дис. ... канд. юрид. наук: 21.07.04. “Оперативно-розшукова діяльність”. Одеса: ОЮО ХНУВС, 2005. $20 \mathrm{c}$.

11. Хірсін A.B. Криміналістичне забезпечення розслідування корисливо-насильницької організованої злочинної діяльності: дис. ... д-ра юрид. наук: 12.00.09. "Кримінальний процес та криміналістика; судова експертиза; оперативно-розшукова діяльність”. К.: КНУВС, 2006. 291 с.

12. Щербакова Г.В. Початковий етап розслідування розбоїв, вчинених з метою заволодіння приватним майном громадян: дис. ... канд. юрид. наук: 12.00.09. "Кримінальний процес та криміналістика; судова експертиза; оперативно-розшукова діяльність”. К.: КНУВС, 2006. 200 с.

13. Бистрицький Б.Ю. Розслідування грабежів, учинених неповнолітніми: автореф. дис. ... канд. юрид. наук : 12.00.09. Нац. акад. внутр. справ. Київ, 2016. 20 с.

14. Калімбет I.Л. Розслідування групових корисливо-насильницьких злочинів неповнолітніх: автореф. дис. ... канд. юрид. наук: 12.00.09. Міжнарод. гуманітар. ун-т. Одеса, 2017. 20 с.

15. Колонюк В.П. Расследование хищений денежных средств и ценных бумаг в сберегательных банках, совершаемых путем кражи, грабежа, разбоя: дис. ... канд. юрид. наук: 12.00.09. К., 1991. 213 c.

16. Кравчук П.Ю. Використання спеціальних знань під час розслідування грабежів і розбоїв: автореф. дис. ... канд. юрид. наук: 12.00.09. Східноєвроп. нац. ун-т ім. Л. Українки. Ірпінь, 2015. $19 \mathrm{c.}$

17. Патик A.A. Взаємодія слідчих та оперативно-розшукових підрозділів при розкритті та розслідуванні майнових злочинів: автореф. дис. ... канд. юрид. наук: 12.00.09. Нац. акад. внутр. справ України. Київ, 2011. 17 с.

18. Чорний Г.О. Методика розслідування розбоїв з проникненням у житло: автореф. дис. ... канд. юрид. наук: 12.00.09. Нац. юрид. акад. України ім. Ярослава Мудрого. Харків, 1998. 18 с.

19. Щербакова Г.В. Початковий етап розслідування розбоїв, вчинених з метою заволодіння приватним майном громадян: автореф. дис. ... канд. юрид. наук: 12.00.09. Київ. нац. ун-т внутр. справ. К., 2006. 18 с.

20. Владимиров В.А., Холостов В.И. Ответственность за грабеж и личность грабителя. М.: ВНИИ МВД СССР, 1976. 340 с.

21. Пашковский B.A. Проблемы борьбы с кражами, грабежами и разбоями. М.: ВНИИ МВД СССР, 1980. 280 с.

22. Цалиев А.М. Корыстно-насильственные преступления и их причины в республиках Северного Кавказа: учеб. пособие / под ред. В.В. Орехова. Ростов-на-Дону: Изд-во Ростов. унта, 1990. 140 c.

23. Литвинов В.И. Корыстные посягательства на личную собственность и их предупреждение. Минск: Университетское, 1989. 271 с.

24. Курашвили А.А. Криминологические проблемы борьбы органов внутренних дел с грабежами и разбоями: учеб. пособие. М.: МВШ МВД СССР, 1990. 58 с.

25. Алауханов E.O. Криминологические проблемы предупреждения корыстно-насильственных преступлений / под ред. Е.И. Каиржанова. СПб.: Изд-во Р. Асланова “Юридический центр Пресс", 2005. 282 с.

26. Коваленко В.И. Криминологическая характеристика современных грабежей и разбоев и меры их предупреждения: автореф. дис. ... канд. юрид. наук: 12.00.08. Ростов-на-Дону: Московский ун-т МВД России, 2003. 35 с.

27. Прохорова М.И. Предупреждение грабежей и разбоев: автореф. дис. ... канд. юрид. наук: 12.00.08. Москва.: Всерос. научно-исслед. ин-т МВД Российской Федерации, 2006. 28 с.

28. Албул С.В., Демедюк Т.С., Користін О.С. та ін. Протидія кримінальним правопорушенням підрозділами карного розшуку МВС України: навч. посіб. Одеса: ОДУВС, 2015. 354 с.

29. Голіна В.В., Колодяжний М.Г., Шрамко С.С. та ін. Громадськість у запобіганні і протидії злочинності: вітчизняний та міжнародний досвід: монографія / за заг. ред. В.В. Голіни, М.Г. Колодяжного. Х.: Право, 2017. 284 с.

DOI (Article): https://doi.org/10.36486/np.2019.2.21

C Fedotova Hanna, Lisnychenko Liliia, 2019 Issue 2(44) 2019 http://naukaipravoohorona.com/ 


\section{REFERENCES}

1. Holozkin B.M. (2011). Teoretychni ta prykladni problemy determinatsii i zapobihannia koryslyvii nasylnytskii zlochynnosti v Ukraini: avtoref. dys. ... kand. yuryd. nauk. "Theoretical and applied problems of determination and prevention of self-serving violent crime in Ukraine": diss. Dr. of Juridical Sciences: Specialist. 12.00.08 "Criminal Law and Criminology; criminal law". KH.: National University "Yaroslav Mudrui Law Academy of Ukraine". 37 p. [in Ukrainian].

2. Batyrhareieva V.S. (2002). Kryminolohichna kharakterystyka ta poperedzhennIa rozboiv, poIednanykh z pronyknennIam u zhytlo: avtoref. dys. ... kand. yuryd. nauk. "Criminological characteristics and prevention of robberies combined with entry into the dwelling": abstract diss. Candidate of Juridical Sciences: Specialist. 12.00.08 "Criminal Law and Criminology; criminal law". KH. 20 p. [in Ukrainian].

3. Vasylerych V.V. (1998). Borotba z ozbroienymy formamy orhanizovanoi zlochynnosti koryslyvoho-nasylnytskoho spriamuvannia: avtoref. dys. ... kand. yuryd. nauk. "Combating Armed Forms of Organized Crime of Selfish and Violent Direction": abstract diss. Candidate of Juridical Sciences: 12.00.08. K.: NAVSU. 18 p. [in Ukrainian].

4. Albul S.V. (2005). Kryminolohichna kharakterystyka koryslyvo-nasylnytskykh zlochyniv vidnosno inozemnykh hromadian: avtoref. dys. ... kand. yuryd. nauk. "Criminological Characteristics of Self-Violent Crimes Against Foreign Citizens": abstract. diss. Candidate of Juridical Sciences: 12.00.08 "Criminal Law and Criminology; criminal law". Odessa, Nat. Odessa Law Academy. 20 p. [in Ukrainian].

5. Nikitenko S.V. (2004). Profilaktyka koryslyvykh ta koryslyvo-nasylnytskykh zlochyniv, skoienykh zhinkamy na tli narkomanii: avtoref. dys. ... kand. yuryd. nauk. "Prevention of selfish and selfish and violent crimes committed by women against drug addiction": abstract diss. Candidate of Juridical Sciences: 12.00.08. "Criminal Law and Criminology; criminal law". KH.: KHNUVS. 214 p. [in Ukrainian].

6. Yanytska N.V. (2000) Hrupova koryslyvo-nasylnytska zlochynnist molodi i yii poperedzhennia: avtoref. dys. ... kand. yuryd. nauk. "Group mercenary violent crime of young people and their warning": abstract. Cand. of Juridical Sciences: 12.00.08. "Criminal law and criminology; penal enforcement law". K. 20 p. [in Ukrainian].

7. Petrov D.V. (2015). Kryminolohichna kharakterystyka ta zapobihannia hrabezham i rozboiam, shcho vchyniaiutsia nepovnolitnimy u hromadskykh mistsiakh: avtoref. dys. ...doct. yuryd. nauk. "Criminological characteristics and prevention of robberies and robberies committed by minors in public places": abstract, Candidate of Juridical Sciences: 12.00.08. "Criminal law and criminology; penal enforcement law". M., National Academy of Public Prosecutor's Office of Ukraine. 255 p. [in Ukrainian].

8. Tyshchenko V.V. (2001-2002). Korystno-nasilstvennyye prestupleniya: kriminalisticheskiy analiz. "Mercenary-violent crimes: forensic analysis". Odessa: Jurid. literature, 2002. 360 p.; Kontseptualnyye osnovy rassledovaniya korystno-nasilstvennykh prestupleniy. "Conceptual framework for the investigation of mercenary-violent crimes": dis. Dr. Juridical Sciences: 12.00.08. X.: NYAU of Yaroslav Mudryi. 2001, 445 p. [in Russian].

9. Piven A.V. (2013). Kryminolohichna kharakterystyka ta profilaktyka vulychnoi nasylnytskoi zlochynnosti. "Criminological characteristics and prevention of street violent crime": abstract. diss. Ph.D.: 12.00.08. Nat. Acad. Intern. Affairs. K. 18 p. [in Ukrainian].

10. Krychun Yu.A. (2005). Osnovy vyiavlennia ta rozsliduvannia koryslyvo-nasylnytskykh zlochyniv: avtoref. dys. ... kand. yuryd. nauk. "Basics of detection and investigation of mercenary violent crimes: abstract. diss. Candidate of Juridical Sciences: 21.07.04. "Operational-search activity". Odessa: OUI KhNUVS. 20 p. [in Ukrainian].

11. Khirsin A.V. (2006). Kryminalistychne zabezpechennia rozsliduvannia koryslyvo-nasylnytskoi orhanizovanoi zlochynnoi diialnosti: avtoref. dys. ... doktor. yuryd. nauk. "Criminalistic support of the investigation of mercenary and violent organized criminal activity": Diss. Dr. of Juridical Sciences: 12.00.09. "Criminal process and criminality; forensic examination; operative-search activity". K., KNUIA. 291 p. [in Ukrainian].

12. Shcherbakova H.V. (2006). Pochatkovyi etap rozsliduvannia rozboiv, vchynenykh z metoiu zavolodinnia pryvatnym mainom hromadian: avtoref. dys. ... kand. yuryd. nauk. "The initial stage of investigation of robberies committed with the purpose of appropriation of private property of

DOI (Article): https://doi.org/10.36486/np.2019.2.21

(C) Fedotova Hanna, Lisnychenko Liliia, 2019 Issue 2(4.4) 2019 http://naukaipravoohorona.com/ 
citizens": dis. Ph.D.: 12.00.09. "Criminal process and forensics; forensic examination; operative-search activity". K.: KNUIA. 200 p. [in Ukrainian].

13 .Bystrytskyi B.Yu. (2006). Rozsliduvannia hrabezhiv, uchynenykh nepovnolitnimy: avtoref. dys. ... kand. yuryd. nauk. "Investigation of robberies committed by minors": abstract. diss. Ph.D.: 12.00.09. Nat. Acad. Intern. Affairs. Kyiv. 20 p. [in Ukrainian].

14. Kalimbet I.L. (2017). Rozsliduvannia hrupovykh koryslyvo-nasylnytskykh zlochyniv nepovnolitnikh: avtoref. dys. ... kand. yuryd. nauk. "Investigation of a group of juvenile and violent crimes of a minor": author. diss. Ph.D.: 12.00.09. International Humanitarian Univ. Odessa. 20 p. Investigation of a group of juvenile and violent crimes of a minor: author. diss. Ph.D.: 12.00.09. International. humanitarian. Univ. Odessa. 20 p. [in Ukrainian].

15. Koloniuk V.P. (1991). Rassledovaniye khishcheniy denezhnykh sredstv i tsennykh bumag v sberegatelnykh bankakh, sovershayemykh putem krazhi, grabezha, razboya: dis. ... kand. yurid. nauk. "Investigation of theft of money and securities in savings banks, committed by theft, robbery, robbery": abstract diss.... Ph.D.: 12.00.09. K. 213 p. [in Russian].

16. Kravchuk P.Yu. (2015). Vykorystannia spetsialnykh znan pid chas rozsliduvannia hrabezhiv i rozboiv: avtoref. dys. ... kand. yuryd. nauk. "The use of specialist knowledge in the investigation of robberies": abstract. diss. Ph.D.: 12.00.09. L. Ukrainka Eastern European National University. Irpin. 19 p. [in Ukrainian].

17. Patyk A.A. (2011). Vzaiemodiia slidchykh ta operatyvno-rozshukovykh pidrozdiliv pry rozkrytti ta rozsliduvanni mainovykh zlochyniv: avtoref. dys. ... kand. yuryd. nauk. "Interaction of investigative and operational-search units in the detection and investigation of property crimes": abstract diss. ... Ph.D: 12.00.09. Nat. Acad. Affairs of Ukraine. Kyiv. 17 p. [in Ukrainian].

18. Chornyi H.O. (1998). Metodyka rozsliduvannia rozboyiv z pronyknenniam u zhytlo : avtoref. dys. ... kand. yuryd. nauk. "The technique of investigating robberies with penetration into the home: abstract. diss. ... Ph.D.: 12.00.09.. Yaroslav Mudrui National Law Academy of Ukraine, Kharkiv. 18 p. [in Ukrainian].

19. Shcherbakova H.V. (2006). Pochatkovyi etap rozsliduvannia rozboiv, vchynenykh z metoiu zavolodinnia pryvatnym mainom hromadian: avtoref. dys. ...kand. yuryd. nauk. "The initial stage of the investigation of robberies committed to seize citizens' private property": abstract. diss. ... Ph.D.: 12.00.09. Kyiv. Nat. Acad. Intern. Affairs. Kyiv. 20 p. [in Ukrainian].

20.Vladimirov V.A., Kholostov V.I. (1976). Otvetstvennost za grabezh i lichnost grabitelya. "Responsibility for the robbery and the identity of the robber. M.: All-Union Research Institute of the Ministry of Internal Affairs of the USSR.340 p. [in Russian].

21. Pashkozsky V.A. (1980). Problemy borby s krazhami, grabezhami i razboyami. "Problems of the fight against theft, robbery and robbery”. M.: All-Union Research Institute of the Ministry of Internal Affairs of the USSR.280 p. [in Russian].

22. Tsaliyev A.M. (1990). Korystno-nasilstvennye prestupleniya i ikh prichiny v respublikakh Severnogo Kavkaza: ucheb. posobiye / pod red. V.V. Orekhova. "Mercenary-violent crimes and their causes in the republics of the North Caucasus: textbook. allowance / ed. V.V. Orekhova. Rostov-onDon: Publishing house Rostov. University. 140 p. [in Russian].

23. Litvinov V.I. (1989). Korystnyye posyagatel'stva na lichnuyu sobstvennost i ikh preduprezhdeniye. "Selfish attacks on personal property and their prevention". Minsk: Universitetskoye. 271 p. [in Russian].

24. Kurashvili A.A. (1990). Kriminologicheskiye problemy borby organov vnutrennikh del s grabezhami i razboyami: ucheb. posobiye. "Criminological problems of the struggle of internal affairs bodies with robberies”: a textbook. allowance. M.: MVS MVD USSR. 58 p. [in Russian].

25. Alaukhanov Ye.O. (2005). Kriminologicheskiye problemy preduprezhdeniya korystnonasilstvennykh prestupleniy / pod red. Ye.I. Kairzhanova. "Criminological problems of the prevention of mercenary-violent crimes" / ed. E.I. Kairzhanova. St. Petersburg: Publishing House of R. Aslanov "Legal Center Press". 282 p. [in Russian].

26. Kovalenko V.I. (2003). "Kriminologicheskaya kharakteristika sovremennykh grabezhey i razboyev i mery ikh preduprezhdeniya": avtoref. dis. ...kand. yurid. nauk: 12.00.08. "Criminological characteristics of modern robberies and robberies and measures to prevent them": author. dis. ...Ph. D: 12.00.08. Rostov-on-Don: Moscow University of the Ministry of Internal Affairs of Russia. 35 p. [in Russian].

27. Prokhorova M.I. (2006). Preduprezhdeniye grabezhey i razboyev: avtoref. dis. ...kand. yurid. nauk: 12.00.08. "Prevention of robbery": author. dis. Ph.D.: 12.00.08. Moscow: Vseros.

DOI (Article): https://doi.org/10.36486/np.2019.2.21

(c) Fedotova Hanna, Lisnychenko Liliia, 2019 
scientific research Institute of the Ministry of Internal Affairs of the Russian Federation. 28 p. [in Russian].

28. Albul S.V., Demedyuk T.S., Korystin O.Ye. ta in. (2005). Protydiia kryminalnym pravoporushenniam pidrozdilamy karnoho rozshuku MVS Ukrainy: navch. posib. "Criminal Offense Against the Criminal Investigation Units of the Ministry of Internal Affairs of Ukraine": Teach. book. Odessa: ODVUS. 354 p. [in Ukrainian].

29. Holina V.V., Kolodyazhnyy M.H., Shramko S.S. ta in. (2017). Hromadskist u zapobihanni i protydii zlochynnosti: vitchyznyanyi ta mizhnarodnyi dosvid: monohrafiia. "The public in crime prevention and counteraction: domestic and international experience": monograph / by general. ed. V.V. Golin, M.H. Well. H.: Right. 284 p. [in Ukrainian].

UDC 343.9

Fedotova Hanna,

Doctor of Juridical Sciences, Senior Research Associate, Head of the Department, State Research Institute MIA Ukraine, Kyiv, Ukraine, ORCID ID 0000-0002-7798-3143,

Lisnychenko Liliia, Research Officer,

State Research Institute MIA Ukraine, Kyiv, Ukraine, ORCID ID 0000-0003-2211-741X

\section{STATE OF SCIENTIFIC AND THEORETICAL DEVELOPMENT OF PROBLEMS WITH PREVENTION OF PLUNDERING AND ROBBERIES}

Forming an effective crime prevention system is one of the most important law enforcement functions of the state policy of Ukraine. The development of the system of protection by criminological means of constitutional rights and freedoms of a person and citizen from criminal encroachments occupies an important place among the objects of criminological research. In different historical periods and times, the importance of social relationships, which have been encroached upon by different types of crime in general and acquisitive crime in particular, has stimulated researchers to search for new scientific ideas through theoretical developments. Problematic aspects of counteracting mercenary and violent crimes were studied by a number of scientists - specialists in criminology, criminal law, criminalistics, criminal procedure. The research of mercenary and violent crimes is devoted to the works of such outstanding foreign and domestic scientists as: S.V. Albul, Yu.M. Antonian, V.V. Batyrhareieva, S.V. Borodin, V.V. Vasylevych, V.V. Holina, B.M. Holovkin, I.M. Danshyn, O.M. Dzhuzha, A.I. Dolhova, Yu.F. Ivanov, V.I. Zadorozhnyi, A.P. Zakaliuk, A.F. Zelinskyi, M.H. Kolodiazhnyi, V.M. Kudriavstev, N.V. Kulakov, S.V. Nikitenko, D.V. Petrov, D.V. Rivman, V.V. Tishchenko, V.I. Shakun, N.V. Yanytska and others. Furthermore, such scholars have contributed significantly to the study of the criminal and legal characteristics of plundering and robberies through scientific research: H.M. Borzenkov, L.D. Vladymyrov, V.A. Haukhman, Ye.B. Halkin, P.I. Hryshaiev, O.I. Hurov, M.D. Durmanov, V.P. Yemelianov, M.Y. Korzavskyi,

DOI (Article): https://doi.org/10.36486/np.2019.2.21

(C) Fedotova Hanna, Lisnychenko Liliia, 2019 Issue 2(44) 2019

http://naukaipravoohorona.com/ 
H.O. Kryher, B.A. Kurinov, Yu.O. Liapunov, P.S. Matyshevskyi, V.O. Navrotskyi, B.S. Nikiforov, A.O. Pinaiev, O.O. Piontkovskyi, S.V. Poznyshev and others.

Despite a significant number of studies on the prevention, disclosure and investigation of plundering and robberies, most of them were carried out during the USSR, the Russian Federation or post-Soviet states. Taking into account the situation that has developed in Ukraine in recent years, in particular, the prolonged economic, political and financial crisis, most of the works have gained importance only as a theoretical value as a scientific and theoretical basis for further improvement of the legal framework designed to prevent plundering and robberies.

Expanded globalization processes are sponsored before the priorities of Ukraine's call policy are included in the European political, informational, economic and legal space. In order to ensure the proper implementation of the obligations of our country arising from membership in the Council of Europe and to achieve membership in the European Union, it is important to take the necessary measures for the convergence of Ukrainian legal norms with European standards. Accordingly, preventing plundering and robberies at the present stage requires the introduction of updated methods in the field of crime prevention, in particular, strict observance of the priority of human and civil rights and freedoms and the service of the state to the interests of human.

In general, the development of social relations and strengthening the role of the state requires a new doctrinal approach to ensuring human security, and this, in turn, determines the conceptual review of existing legislative provisions on the regulation of the concepts of "plunder" and "robbery", as well as forms, methods and means of preventing the commission of these crimes.

Keywords: criminal and legal analysis, crime prevention, crime, mercenary violent crimes, robbery, plunder.

Отримано 07.06.2019 


\title{
ЮРИДИЧНА ПСИХОЛОГІЯ ТА ПЕДАГОГІКА. ПСИХОЛОГІЧНЕ ЗАБЕЗПЕЧЕННЯ ПРАВООХОРОННОЇ ДІЯЛЬНОСТІ
}

УДК 159.922

\author{
Барко Вадим Іванович, \\ доктор психологічних наук, професор, \\ головний науковий співробітник \\ ДНДІ МВС України \\ м. Київ, Україна, \\ ORCID ID 0000-0003-4962-0975; \\ Барко Вадим Вадимович, \\ кандидат педагогічних наук, \\ старший науковий співробітник \\ ДНДІ МВС України \\ м. Київ, Україна, \\ ORCID ID 0000-0002-3836-2627 \\ Кирієнко Людмила Андріївна, \\ провідний науковий співробітник \\ ДНДІ МВС України \\ м. Київ, Україна, \\ ORCID ID 0000-0001-9394-1288
}

\section{РОЗРОБЛЕННЯ УКРАЇНОМОВНОГО ОПИТУВАЛЬНИКА ТОЛЕРАНТНОСТІ ДО НЕВИЗНАЧЕНОСТІ ДЛЯ ВИКОРИСТАННЯ В НАЦІОНАЛЬНІЙ ПОЛІЦІЇ УКРАЇНИ}

Стаття присвячена питанню україномовної адаптачї̈ психодіагностичної методики “Опитувальник толерантності до невизначеності" С. Баднера в межах удосконалення системи професійного добору кадрів для Національної поліщії України. Викладено теоретичні основи і внутрішню структуру процесу адаптації, розкрито процедуру та результати дослідження щодо перевірки надійності та валідності методики, отримані середньонормативні показники для загальної вибірки, визначені нові стандартизовані тестові норми. Результати дослідження довели діагностичну верифікачію зазначеного опитувальника.

Ключові слова: толерантність до невизначеності, психодіагностичні методики, україномовна адаптаџія, надійність, валідність, середньонормативні показники, стандартизовані тестові норми.

Важливим напрямом підвищення ефективності діяльності Національної поліції України є вдосконалення системи професійного добору кадрів. Згідно 3 нормативними документами МВС, конкурс на службу до поліції проводиться в

() Barko Vadym I., Barko Vadym V., Kyriienko Liudmyla, 2019 DOI (Article): https://doi.org/10.36486/np.2019.2.22 
кілька етапів, одним із яких є проведення психологічного тесту з метою вивчення особистісних характеристик кандидатів. Варто відзначити, що наразі не вистачає надійних україномовних тестів (опитувальників), які могли б застосовуватися із цією метою. Традиційно психологами використовуються зарубіжні (зазвичай російські) методики й адаптовані російською мовою англомовні тести, українськомовні опитувальники практично відсутні [1-7]. Подібну ситуацію не можна вважати задовільною, оскільки не всі респонденти володіють російською мовою достатньою мірою, до того ж використання в текстах опитувальників ментально інших (чужих) особистісних дескрипторів нерідко призводить до помилок у відповідях і невірних психодіагностичних висновків. Тому постає проблема українськомовної адаптації деяких найбільш валідних і надійних психологічних опитувальників для дослідження особистісних характеристик.

Метою цієї статті є адаптація українською мовою однієї із широко використовуваної психологами зарубіжних діагностичних методик - “Опитувальник толерантності до невизначеності" С. Баднера.

Аналізуючи сучасні глобальні соціальні проблеми, можна відзначити, що суспільне буття у XXI столітті характеризується зростаючою невизначеністю, яка торкається усіх сторін буття. Зазначене стосується й усіх сфер життєдіяльності людини. На думку К. Вульфа, невизначеність є елементом культури, умовою створення людиною будь-якого продукту діяльності, невід’ємною умовою вільного, продуктивного життя [3, с. 24]. В.П. Зінченко і Т.В. Корнілова небезпідставно пишуть про принцип невизначеності, який в нашому столітті співіснує з принципом детермінізму, причому, в психологічному сенсі, невизначеність виступає у вигляді виклику людству [4, с. 15; 6, с. 75]. Упродовж ХХ століття ми спостерігаємо в філософії різні прояви руху в напрямі від розуміння світу як міцного, стійкого, передбачуваного, керованого і детермінованого до його розуміння як переважно некерованого, недетермінованого, непередбачуваного, неоднозначного. На думку Д.О. Леонтьєва, це проявляється у трьох ключових сферах: зміні образу людини, зміні образу науки і зміні статусу цінностей [9-11]. Принцип невизначеності проявляється також у сфері поліцейського менеджменту.

Упродовж останніх десятиліть докорінно змінились образи людини, які існували раніше. Сучасні мислителі, зокрема, Е. Фромм, відзначають, що природа людини полягає у тому, що у неї взагалі немає фіксованої природи, сутність людини - це можливість розвиватись у будь-якому обраному напрямі [21, с. 80]. Єдине, що можна сказати упевнено, це те, що людина дуже різна, вона виходить за межі заданого, її сутність полягає в трансценденції. Як вважає методолог природознавства I. Пригожин, упродовж XX століття докорінно змінився й образ науки [16, с. 50]. Традиційно вважалось, що наука описує стабільні, детерміновані процеси, проте, чим більше поглиблювалось пізнання, тим помилковішою виявлялась подібна думка. І. Пригожин став Нобелівським лауреатом за відкриття в неорганічній природі, так званих, біфуркаційних процесів, тобто процесів, які не детерміновані повністю, в яких виникають розриви детермінації. Процес може прийняти різні напрями і неможливо визначити конкретний шлях, за яким він піде. Саме в нерівноважних системах можливе розширення масштабів самої системи, зміна відносин із зовнішнім середовищем, в таких системах відбувається істинний

(c) Barko Vadym I., Barko Vadym V., Kyriienko Liudmyla, 2019

DOI (Article): https://doi.org/10.36486/np.2019.2.22 
розвиток. Нарешті, змінилась картина світу, яка існувала упродовж тисячоліть, оскільки порушилась система непохитних цінностей. У XX столітті виникла, так звана, постмодерністська система світу. Постмодернізм, на думку Д.О. Леонтьєва, філософськи коректно доведена відсутність об'єктивних підстав існування ціннісних систем, якщо не вважати такою підставою історичні аспекти прийняття певних цінностей на окремих територіях [10].

У системі поліції в міру розвитку науково-технічного прогресу, ускладнення праці, підвищення рівня освіти населення, успіх все більше залежить від знань і здібностей працівників, ступеня їх підготовки. Зростає роль мотивації поліцейського, який в умовах складної, часом творчої роботи, стає саморегульованою системою, коли працівник визначає власну поведінку, керівник на нього може впливати лише опосередковано, віддаючи перевагу не адмініструванню, а реалізації тих стилів керівництва, які передбачають співучасть, визнання особистих заслуг конкретних працівників поліції, гласність результатів діяльності, надання інформації для самооцінки. При цьому поліцейська діяльність в сучасному суспільстві також характеризується зростаючою невизначеністю. Поліцейській службовій діяльності властиві специфічні психологічні особливості, а саме: 1) значна відповідальність за прийняті рішення; 2) опосередкованість операцій через наявність статутних відносин; 3) необхідність діяти в умовах неоднозначності й невизначеності; 4) неалгоритмічний характер багатьох операцій; 5) жорстка детермінація операцій часовими параметрами, заданими організаційними умовами; 6) значний обсяг та різноманітність оперативних завдань і дій; 7) соціотехнічний характер дій; 8) висока психологічна напруженість діяльності; 9) значна залежність ефективності дій від індивідуально-психологічних якостей особи; 10) значна залежність результату діяльності поліцейського від чинників, які перебувають поза межами регулюючого впливу.

На думку дослідників, вихід з екзистенціального кута, створеного невизначеністю, вбачається у виробленні особистістю жорсткої внутрішньої структури і прийняття відповідальності за підстави своєї поведінки, самостійному створенні суб’єктивних критеріїв власної діяльності $[2 ; 5 ; 12 ; 21 ; 22]$. Це стосується і поліцейських, які діють переважно в умовах невизначеності.

Невизначеність стала найважливішою характеристикою суспільного життя, іï̈ атрибутом. У світі дуже багато невизначеності, вона абсолютна, а відрізки визначеності - короткі - відзначають В.А. Кувакін і В.П. Ковальова [8, с. 112]. Відомий філософ А. Бадью вводить важливе поняття “готовність до події” як особливість стратегії поведінки людини, яка готова до ситуації невизначеності [2, c. 47]. Отже, невизначеність крім неприємних емоцій містить у собі важливий, позитивний потенціал для людини, яка може, виробивши в собі адекватну позицію стосовно невизначеності, відчути властиві їй позитивні можливості. Готовність до події, на думку В.П. Зінченка, є, по суті, готовністю до невизначеності або готовністю до вибору [4, с. 20].

Більшість людей до невизначеності відносяться негативно. Клінічний аналіз проблеми суб'єктивної невизначеності дозволив ученим описати п'ять типів її переживання, з яких чотири мають негативний характер [18]. Позитивне ставлення до невизначеності можливе, саме воно виявляється найбільш продуктивним для

(C) Barko Vadym I., Barko Vadym V., Kyriienko Liudmyla, 2019

DOI (Article): https://doi.org/10.36486/np.2019.2.22

Issue 2(4.4) 2019

http://naukaipravoohorona.com/ 
особистісного розвитку поліцейських і опірності стресам. Сутність такого ставлення полягає в тому, щоб відмовитися від ілюзії стабільності й однозначності картини світу і виробляти позицію прийняття невизначеності, з якою з'являться нові можливості. Ріст толерантності до невизначеності виявився одним із найбільш універсальних наслідків роботи в екзистенціальних дослідженнях. У результаті зміни ставлення до невизначеності вона перестає бути чимось, чого потрібно боятися і від чого слід тікати, а починає приносити людям задоволення, завдяки чому вони набувають здатності відчувати позитивні емоції.

Сьогодні розроблено кілька опитувальників, що використовуються з метою психологічної діагностики толерантності особистості до невизначеності [4; 6; 14]. Одним із найчастіше використовуваних методичних засобів у дослідженнях толерантності до невизначеності (TH) є опитувальник С. Баднера TAS (Tolerance Ambiguity Scale), уперше опублікований у 1962 році. Толерантність до невизначеності (ТН) розглядається Баднером як індивідуальна схильність (схильність) розглядати (оцінювати) невизначені ситуації як бажані, або у випадку прояву інтолерантності до невизначеності (ITH) - як загрозливі. Толерантність до невизначеності є особистісною рисою, що визначає ставлення індивіда до неоднозначних, невизначених, тривожних ситуацій незалежно від емоційного знаку цієї невизначеності. Особа, толерантна до невизначеності, розглядає будь-яку невизначену ситуацію як можливість вибору, розвитку, набуття нового досвіду, не відчуває деструктивної тривоги в невизначених ситуаціях, здатна активно і продуктивно діяти в них. Проте особа інтолерантна до невизначеності в ситуаціях невизначеності (або навіть загрози її виникнення) демонструє високий рівень тривожності, навіть якщо ця невизначеність означає позитивні зміни в майбутньому. Інтолерантні до невизначеності особи схильні до жорсткої регламентації усіх сфер життя, у тому числі стосунків і систем набуття досвіду. Таким чином, поняття інтолерантності до невизначеності зближується з поняттям ригідності, а толерантність - 3 поняттям життєстійкості [13].

Традиційно психологія досліджує феномен толерантності до невизначеності в контексті вивчення його взаємозв’язку з особистісними рисами. Так, наприклад, пропонувалося розглядати толерантність до невизначеності як частину чинника “Великої п’ятірки”, який називають відкритістю досвіду і враженням (openness to experience). У спеціальному дослідженні академічної успішності студентів показано, що відкритість новому досвіду виявляється пов'язаною у студентів з благополуччям упродовж “академічних переходів” (вступ до вузу, адаптація до нього) за допомогою інтерпретації труднощів і загроз, а ТН пов’язана з благополуччям тільки на початковому етапі навчання, коли присутні невизначеність, новизна i неясність ситуації. Дослідження вибірки 510 студентів підтвердило, що толерантність до невизначеності не є предиктором благополуччя, коли студенти стають більш досвідченими. Толерантність до невизначеності також може корелювати 3 інтелектом, оскільки також пов'язана з чинниками “Великої п'ятірки”: позитивно 3 відкритістю досвіду і екстраверсією, негативно - з нейротизмом [24; 25].

Ставлення до невизначеності зазвичай розглядається в двох напрямах: прийняття умов невизначеності (їх пошук, уміння діяти в них) і уникнення невизначеності (страх невизначеності), прагнення до ясності.

(c) Barko Vadym I., Barko Vadym V., Kyriienko Liudmyla, 2019

DOI (Article): https://doi.org/10.36486/np.2019.2.22 
Опитувальник толерантності до невизначеності Баднера (ТНБ) є досить зручним і “економічним”, адже складається з 16 пунктів. Авторська версія пропонує опитувальник з трьома шкалами: (1) новизна проблеми, (2) її складність і (3) нерозв’язність. ТНБ й наразі залишається одним із найбільш відомих і найчастіше використовуваних у дослідженнях толерантності до невизначеності, що пов'язано передусім з його високою конструктною валідністю, яка була досягнута при його розробці та апробації шляхом ретельного співвідношення отримуваних результатів із біографічними даними опитуваних, показниками соціальної оцінки, вибором кар'єри, ставленням до релігії та іншими соціальними показниками, а також 3 багатьма психологічними змінними.

Здійснювалась валідизація російськомовного варіанту опитувальника. У практикумі з діагностики толерантності особистості Солдатової відсутні дані щодо валідизації методики, згадується лише, що обсяг вибірки складав 58 осіб. У дослідженні Корнілової взяли участь 1082 осіб у віці від 17 до 82 років, 704 жінки і 376 чоловіків. Загальна вибірка складалася з кількох груп респондентів: студентів, викладачів і військовослужбовців [7, с. 98]. Для оцінки конвергентної валідності опитувальника застосовувалася шкала толерантності до невизначеності Д. Маклейна (MSTAT-1) в адаптації Е.Г. Луковицької. За результатами статистичного аналізу виявлено достовірне підвищення інтолерантності до невизначеності з віком, а також більший її рівень у чоловіків, хоча ця відмінність невелика, тому можна стверджувати, що методика неспецифічна відносно статі й віку. При множинному попарному порівнянні груп було встановлено, що значимо виділяються дві підвибірки: група військовослужбовців і група студентів академії театрального мистецтва. Встановлено також, що толерантність до невизначеності слабо позитивно пов'язана з готовністю до ризику і з показником толерантності/ інтолерантності за опитувальником Маклейна [7].

3 метою експериментального дослідження психодіагностичних можливостей методики Баднера та її адаптації використано результати опитування працівників Національної поліції України упродовж 2018 року. Для тестування були відібрані працівники, яких поважають у колективі та яким притаманні високі моральноділові якості. Тестування проводилось у десяти областях України (Вінницька, Хмельницька, Херсонська, Миколаївська, Черкаська, Київська, Харківська, Житомирська, Полтавська), усього обстежено 390 респондентів (310 чоловіків і 80 жінок). Для вирішення питання відповідності базових норм методики Баднера, а також коректності їх використання при тестуванні працівників поліції проведене експериментальне дослідження. Спочатку за допомогою трьох перекладачів, а також психологів Державного науково-дослідного інституту (ДНДІ) МВС України розроблений українськомовний варіант опитувальника, текст якого максимально наближений до змісту оригінальної версії, в якій використовувалися традиційні для української мови особистісні дескриптори. 3 метою уникнення труднощів із розумінням змісту тверджень були виключені речення з подвійними запереченнями. Для перевірки надійності та валідності опитувальника здійснено відповідні розрахунки. Під час українськомовної адаптації отримано дані щодо трьох видів надійності шкали: ретестової надійності, паралельних форм і внутрішньої узгодженості.

(c) Barko Vadym I., Barko Vadym V., Kyriienko Liudmyla, 2019

DOI (Article): https://doi.org/10.36486/np.2019.2.22

Issue 2(4.4) 2019

http://naukaipravoohorona.com/ 
Ретестова надійність виражається через коефіцієнт кореляції між двома послідовними тестуваннями з інтервалом у 2 тижні; вона становить: для шкали (1) - новизна проблеми - 0,70; шкали (2) - складність - 0, 68; і шкали (3) - нерозв’язність - 0,66 $(\mathrm{N}=380) ; \mathrm{p}=0,01)$. Отримані значення відповідають психометричним вимогам. Для частини цивільних обстежуваних, які добре володіють українською та англійською мовами (слухачі магістратури факультету іноземних мов НПУ імені М. Драгоманова), пропонувались різномовні варіанти опитувальника, які розглядались як паралельні форми (обидві форми складаються з однакової кількості завдань; попарно вирівняні за структурою і змістом; результати, отримані з їх допомогою, близькі між собою). Коефіцієнти кореляції, одержані при тестуванні $з$ двотижневим інтервалом, виявились такими: для шкали 1 - 0,70; шкали 2 - 0,76; шкали 3 - 0,72; $(\mathrm{N}=375 ; \mathrm{p}=0,01)$. Таким чином, надійність паралельних форм є задовільною. При перевірці за допомогою t-критерію Ст'юдента також не зафіксовано значущих відмінностей між розподілом тестових показників за обома формами (українсько- і англомовною). При перевірці за допомогою критерію Пірсона $\chi^{2}$ також не зафіксовано значущих відмінностей між результатами. Отже, україномовну і англомовну версії опитувальника можна вважати майже тотожними.

3 метою перевірки внутрішньої узгодженості завдань опитувальника розраховувався коефіцієнт $\alpha$-Кронбаха (табл. 1). Отримані показники можна вважати допустимими в аспекті вимог до психодіагностичного інструментарію; невеликі значення коефіцієнтів можна пояснити незначною кількістю тверджень, які входять до тієї чи іншої шкали опитувальника.

Таблиия 1

\section{Коефіцієнти б-Кронбаха для опитувальника Баднера}

\begin{tabular}{|c|c|c|c|}
\hline \multirow{2}{*}{} & \multicolumn{3}{|c|}{ Шкали ТНБ } \\
\cline { 2 - 4 } & $\mathbf{1}$ & $\mathbf{2}$ & $\mathbf{3}$ \\
\hline $\boldsymbol{\alpha}$ & 0,67 & 0,69 & 0,65 \\
\hline
\end{tabular}

Примітка: $\mathrm{p}=0,01 . \mathrm{N}=380$. Шкали ТНБ: 1 - новизна проблеми; 2 - складність; 3 нерозв'язність.

Таким чином, отримані результати свідчать про задовільну надійність адаптованого україномовного опитувальника Баднера.

3 метою дослідження конструктної валідності адаптованого опитувальника Баднера проведене порівняння отриманих даних із результатами інших методик, зокрема Д. Маклейна в адаптації С. Осіна. Виявлено середні за величиною кореляції між показниками толерантності до невизначеності за адаптованим опитувальником Баднера і шкалою толерантності до невизначеності Маклейна $(\mathrm{r}=0,39)$. Крім цього, виявлено кореляцію шкал ТНБ з деякими шкалами опитувальника Маклейна (табл. 2).

() Barko Vadym I., Barko Vadym V., Kyriienko Liudmyla, 2019

DOI (Article): https://doi.org/10.36486/np.2019.2.22 
Кореляції шкал ТНБ і МакЛейна

\begin{tabular}{|c|c|c|c|c|c|c|}
\hline \multirow{2}{*}{ Шкали ТНБ } & \multicolumn{7}{|c|}{ Шкали МакЛейна } \\
\cline { 2 - 7 } & $\mathbf{1}$ & $\mathbf{2}$ & $\mathbf{3}$ & $\mathbf{4}$ & $\mathbf{5}$ & $\mathbf{6}$ \\
\hline $\mathbf{1}$ & $0,29 *$ & 0,03 & $0,43^{* *}$ & 0,20 & 0,20 & $0,31 *$ \\
\hline $\mathbf{2}$ & 0,03 & $0,34^{*}$ & $0,38^{* *}$ & 0,02 & 0,21 & 0,15 \\
\hline $\mathbf{3}$ & 0,10 & 0,06 & 0,16 & $0,31 *$ & $0,30^{*}$ & 0,20 \\
\hline $\begin{array}{c}\text { Загальний } \\
\text { індекс }\end{array}$ & $0,37^{* *}$ & $0,32 *$ & 0,24 & $0,42^{* *}$ & $0,30^{*}$ & $0,39 * *$ \\
\hline
\end{tabular}

Примітка: ${ }^{*}-\mathrm{p}=0,05,{ }^{* *}-\mathrm{p}=0,01 ; \mathrm{N}=380$.

Шкали Маклейна: 1 - ставлення до новизни, 2 - ставлення до складних завдань, 3 - ставлення до невизначених ситуацій, 4 - перевага невизначеності, 5 - толерантність до невизначеності, 6 - загальний бал. Шкали ТНБ: 1 - новизна проблеми; 2 - складність; 3 - нерозв’язність.

У табл. 3-4 наведено середньонормативні статистичні показники за методикою ТНБ, отримані на загальній вибірці поліцейських.

Таблиия 3

Статистичні показники, отримані в процесі тестування працівників поліції (загальна вибірка $\mathrm{N}=390,280$ чоловіки; 110 - жінки)

\begin{tabular}{|c|c|c|c|c|c|c|c|c|}
\hline & \multicolumn{7}{|c|}{ Шкали ТНБ } \\
\hline & \multicolumn{2}{|c|}{1} & \multicolumn{2}{|c|}{2} & \multicolumn{2}{|c|}{3} & \multicolumn{2}{c|}{$\begin{array}{c}\text { Сумарний } \\
\text { індекс }\end{array}$} \\
\hline & ч & ж & ч & ж & Ч & ж & ч & ж \\
\hline $\mathbf{M}$ & 15,2 & 13,4 & 26,1 & 27,5 & 13,3 & 12,1 & 62,7 & 57,2 \\
\hline$?$ & 3,20 & 4,12 & 5,13 & 4,51 & 2,93 & 3,11 & 10,22 & 10,10 \\
\hline
\end{tabular}

Примітка: ч - чоловіки; ж - жінки. Шкали ТНБ: 1 - новизна проблеми; 2 - складність; 3 - нерозв’язність. Курсивом виділено показники, за якими зафіксовано статистично значущі відмінності $(\mathrm{p}=0,05)$.

За результатами статистичного аналізу виявлено достовірне зменшення толерантності до невизначеності у жінок (за шкалами 1 - новизна проблеми і 2 нерозв’язність); а також за інтегральним індексом (відмінності за шкалою 2 статистично не значущі). Відзначено вікове зниження толерантності до невизначеності; працівники поліції віком до 30 років мають вищі індекси толерантності (58,3 бали) проти більш досвідчених (40 років і старші) (65,5 балів; $\mathrm{p}=0,05)$.

Зважаючи на наші розрахунки, середніми значеннями за сумарним індексом вважається показник 60,2 балів, а середньоквадратичне відхилення має значення

( ) Barko Vadym I., Barko Vadym V., Kyriienko Liudmyla, 2019

DOI (Article): https://doi.org/10.36486/np.2019.2.22 
10,11 балів. “Коридор” середніх значень за шкалами методики ТНБ знаходиться в інтервалі 51-75 балів. Бали нижчі та вищі зазначеного інтервалу вважаються низькими та високими відповідно незалежно від освітнього рівня респондента. При перенесенні тестування в інше соціокультурне середовище (відмінне від зазначеного в апробації) коридори низьких, середніх та високих балів можуть змінитися.

Середньонормативні показники за методикою ТНБ на вибірці працівників поліції (емпіричні дані) і вибірці фахівців інших професій (педагогічних, медичних, базові дані Корнілової) наведено в табл. 4. Порівняння свідчить про певне розходження “базових” та “емпіричних” оцінок за методикою ТНБ.

\section{Порівняння середньонормативних показників, отриманих у процесі рестандартизації}

а) емпіричні статистичні дані $(N=390)$

\begin{tabular}{|c|c|c|c|c|}
\hline & \multicolumn{4}{|c|}{ Шкали ТНБ } \\
\cline { 2 - 5 } & 1 & 2 & 3 & Сумарний індекс \\
\hline $\mathbf{M}$ & 14,1 & 26,1 & 13,0 & 60,7 \\
\hline $\boldsymbol{\sigma}$ & 3,40 & 4,51 & 3,31 & 10,10 \\
\hline
\end{tabular}

б) базові статистичні дані $(N=1082)$

\begin{tabular}{|c|c|c|c|c|}
\hline \multirow{2}{*}{} & \multicolumn{4}{|c|}{ Шкали ТНБ } \\
\cline { 2 - 5 } & 1 & 2 & 3 & Сумарний індекс \\
\hline $\mathbf{M}$ & 12,6 & 21,2 & 12,5 & 57,9 \\
\hline $\boldsymbol{\sigma}$ & 3,72 & 4,13 & 3,22 & 9,15 \\
\hline
\end{tabular}

Примітка: курсивом виділено показники, за якими зафіксовано статистично значущі відмінності ( $=0,05)$.

Зауважимо, що за всіма шакалами наявні відмінності між базовими даними і отриманими на вибірці поліцейських. Так, середні показники за шкалами 1-3 у середовищі працівників поліції дещо вищі від нормативних, отриманих в іншому соціокультурному середовищі, проте статистично значущі відмінності зафіксовано тільки за шкалою 2 (складність).

Отримані результати свідчать про вищий рівень толерантності до невизначеності у поліцейських, особливо це виявляється при розв'язанні складних проблем. Для працівників поліції властиві здатність протистояти не лише складним проблемам, а й діяти в умовах, коли завдання здається нерозв'язним. Отримані результати узгоджуються із раніше виявленими (на основі Індивідуально-типологічного опитувальника) рисами поліцейських (висока працездатність, стресостійкість, сміливість, активність, екстраверсія, спонтанність і рішучість; поліцейські вміють легко та швидко, часто за власною ініціативою, вступати у контакти 3 незнайомими або малознайомими людьми, вони мають значний комунікативний

(C) Barko Vadym I., Barko Vadym V., Kyriienko Liudmyla, 2019

DOI (Article): https://doi.org/10.36486/np.2019.2.22

Issue 2(4.4) 2019

http://naukaipravoohorona.com/ 
досвід, водночас комунікативним відносинам часто властивий поверховий та нетривалий характер).

Також за допомогою адаптованого опитувальника обстежено 85 слухачів магістратури Харківського національного університету внутрішніх справ (ХНУВС). Встановлено, що слухачі магістратури ХНУВС з високою толерантністю до невизначеності мають вищі академічні показники успішності (r=0,37; $\mathrm{p}=0,01)$. Крім того, проведений аналіз свідчить про відсутність взаємозв'язку показників толерантності до невизначеності з показниками творчих здібностей (за тестом В. Меде і К. Піорковського). Проте виявлено взаємозв’язок показників толерантності до невизначеності з рівнем емоційного інтелекту (за адаптованою нами методикою MEI М. Манойлової), причому з компонентами міжособистісної складової емоційного інтелекту: обстежувані з більш високою толерантністю краще розуміють емоції інших і здатні ними управляти. Також виявлено, що поліцейські з більш високою толерантністю до невизначеності також демонструють більший рівень задоволеності службовою діяльністю $(\mathrm{r}=0,40 ; \mathrm{p}=0,01)$, що опосередковано свідчить про вищий рівень їх професійної придатності.

Наведемо україномовний варіант адаптованого опитувальника С. Баднера:

\begin{tabular}{|c|c|c|c|c|c|c|c|c|}
\hline № & Твердження & $\begin{array}{l}T \\
T \\
0 \\
0 \\
0 \\
0 \\
0 \\
0 \\
0 \\
0 \\
0 \\
0 \\
0 \\
0 \\
0 \\
0 \\
\end{array}$ & 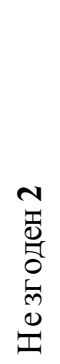 & 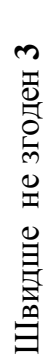 & 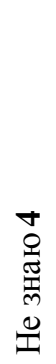 & 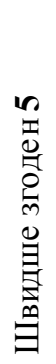 & $\begin{array}{l}0 \\
\text { D. } \\
0 \\
0 \\
0 \\
0\end{array}$ & 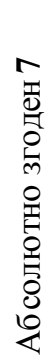 \\
\hline 1. & $\begin{array}{l}\text { Фахівцю, який не може дати чітку } \\
\text { відповідь, мабуть, бракує знань }\end{array}$ & & & & & & & \\
\hline 2. & Я б хотів пожити за кордоном якийсь час & & & & & & & \\
\hline 3. & $\begin{array}{l}\text { Будь-які проблеми можливо так чи } \\
\text { інакше вирішити }\end{array}$ & & & & & & & \\
\hline 4. & $\begin{array}{l}\text { Люди, які підпорядкували своє життя } \\
\text { ч іткому розкладу, напевно, позб авляють } \\
\text { себе багатьо х радощів }\end{array}$ & & & & & & & \\
\hline 5. & $\begin{array}{l}\text { Хороша робота - це така, коли завжди } \\
\text { зрозуміло, що і як треба робити }\end{array}$ & & & & & & & \\
\hline 6. & $\begin{array}{l}\text { Цікавіше займатися складною } \\
\text { проблемою, } \\
\text { ніж вирішувати просту } \\
\end{array}$ & & & & & & & \\
\hline 7. & $\begin{array}{l}\text { У перспективі можна досягти більшого, } \\
\text { вирішуючи маленькі, прості } \\
\text { проблеми, ніж великі і складні }\end{array}$ & & & & & & & \\
\hline 8. & $\begin{array}{l}\text { Найцікавіші люди - це ті, хто не боїться } \\
\text { буги оригінальним і не схожим на інших }\end{array}$ & & & & & & & \\
\hline 9. & $\begin{array}{l}\text { 3вичне завжди прийнятніше, ніж } \\
\text { незнайоме }\end{array}$ & & & & & & & \\
\hline 10. & $\begin{array}{l}\text { Люди, які наполягають на відповіді “так” } \\
\text { або “ні”, просто не знають, наскільки усе } \\
\text { насправді складно. }\end{array}$ & & & & & & & \\
\hline
\end{tabular}

(c) Barko Vadym I., Barko Vadym V., Kyriienko Liudmyla, 2019

DOI (Article): https://doi.org/10.36486/np.2019.2.22 


\begin{tabular}{|c|c|c|c|c|c|c|c|c|}
\hline № & Твердження & $\begin{array}{l}\bar{T} \\
\text { J } \\
0 \\
0 \\
0 \\
0 \\
0 \\
0 \\
0 \\
0 \\
0 \\
0 \\
0 \\
8 \\
0\end{array}$ & 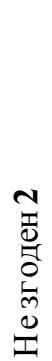 & 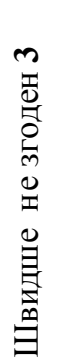 & 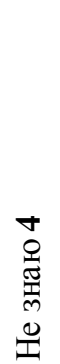 & 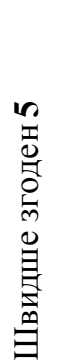 & $\begin{array}{l}0 \\
\text { 章 } \\
\text { 离 } \\
0\end{array}$ & 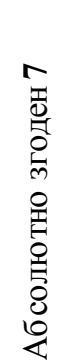 \\
\hline 11. & $\begin{array}{l}\text { Людина, яка веде розмірене життя без } \\
\text { особливих сюрпризів і несподіванок, має } \\
\text { буги вдячна долі }\end{array}$ & & & & & & & \\
\hline 12. & $\begin{array}{l}\text { Більшість найважливіших рішень } \\
\text { приймаються на осно ві неповної } \\
\text { інформації }\end{array}$ & & & & & & & \\
\hline 13. & $\begin{array}{l}\text { Я віддаю перевагу вечіркам зі знайом ими } \\
\text { людьми, аніж веч іркам, на яких } \\
\text { більшість запрошених мені незнайомі }\end{array}$ & & & & & & & \\
\hline 14. & $\begin{array}{l}\text { У чителі та наставники, які нечітко } \\
\text { формулюють завдання, дають шанс } \\
\text { проявити } \\
\text { інішіативу і оригінальність. }\end{array}$ & & & & & & & \\
\hline 15. & $\begin{array}{l}\text { Чим швидше усі прийдуть до єдиних } \\
\text { цінностей та ідеалів, тим краще }\end{array}$ & & & & & & & \\
\hline 16. & $\begin{array}{l}\text { Хороший учитель - той, хто стимулює } \\
\text { формування в учнів власних поглядів }\end{array}$ & & & & & & & \\
\hline
\end{tabular}

Обробка результатів: необхідно підрахувати загальну суму балів, набраних за усіма шістнадцятьма пунктами. Чим вищий цей показник, тим респондент більш толерантний до невизначеності. Підрахунок суми балів за окремими субшкалами дозволяє виявити основне джерело толерантності до невизначеності: новизну, складність і нерозв'язність проблеми.

Субшкалам відповідають такі пункти: новизна: 2, 9, 11, 13. Складність: 4, 5, $6, \mathbf{7}, 8,10,14, \mathbf{1 5}, 16$. Нерозв’язність: $\mathbf{1}, 3,12$. Жирним шрифтом виділено реверсні бали $(1 ; 5 ; 7 ; 9 ; 11 ; 13 ; 15)$.

У таблиці 5 наведено трирівневу порядкову шкалу для оцінки толерантності до невизначеності.

Таблиия 5

Рівні сформованості толерантності до невизначеності

\begin{tabular}{|c|c|c|c|}
\hline Шкала & Низький рівень & Середній рівень & Високий рівень \\
\hline Загальний показник & $16-50$ & $51-75$ & $76-112$ \\
\hline Новизна & & & $22-28$ \\
\hline Складність & $4-8$ & $9-21$ & $37-63$ \\
\hline Нерозв'язність & $9-20$ & $21-36$ & $17-21$ \\
\hline
\end{tabular}

(c) Barko Vadym I., Barko Vadym V., Kyriienko Liudmyla, 2019

DOI (Article): https://doi.org/10.36486/np.2019.2.22 
3 огляду на результати дослідження можна відзначити, що саме толерантність до невизначеності є професійно важливою рисою поліцейського при проведенні добору, а під час професійного навчання цю якість необхідно діагностувати, враховувати і усіляко зміцнювати й розвивати. Саме така особистісна якість, як толерантність до невизначеності, забезпечить підвищення ефективності діяльності поліцейських, оскільки дозволить краще переносити непередбачувані ситуації, які постійно супроводжують службову діяльність; відкриє можливості для креативного осмислення складних професійних ситуацій, пошуку варіативних рішень; збільшить стресостійкість і посилить продуктивні механізми психологічного захисту особистості (раціоналізація, сублімація, витіснення); посилить психологічну готовність і надійність особистості до дій в особливих і екстремальних умовах; сприятиме збереженню психологічного здоров’я поліцейського. Нами здійснено україномовну адаптацію опитувальника толерантності до невизначеності; на-ведено єдиний підхід до організації та проведення тестування; визначено нові стандартизовані тестові норми, впровадження яких сприятиме підвищенню якості оцінювання результатів тестування поліцейських при проведенні конкурсу на службу до поліції або зайняття вакантної посади; розраховані показники надійності та валідності опитувальника. Отримані середньонормативні показники для загальної вибірки можна вважати еталонними при тестуванні працівників на службу до підрозділів поліції.

\section{СПИСОК ВИКОРИСТАНИХ ДЖЕРЕЛ} 2001.

1. Асмолов А.Г. Психология личности: принципы общепсихологического анализа. М.: Смысл,

2. Бадъю А. Философия и событие. М.: ИОИ, 2013.

3. Вульф К. Вместо предисловия: неопределенность как условие человеческой жизни. В кн. Вульф К., Савчук В. Неопределенность как вызов. Медиа. Антропология. Эстетика. СПб.: РХГА, 2013. С. 5-6.

4. Зинченко В.П. Толерантность к неопределенности: новость или психологическая традиция? В кн. Болотова А.К. Человек в ситуации неопределенности. М.: ТЕИС, 2007. С. 9-33.

5. Канеман Д., Словик П., Тверски А. Принятие решений в неопределенности: правила и предубеждения. Харьков: Гуманитарный центр, 2005.

6. Корнилова T.B. Принцип неопределенности в психологии: основания и проблемы. Психологические исследования, 2010. № 3(11), С. 11.

7. Корнилова Т.В., Чумакова М.А. Шкалы толерантности и интолерантности к неопределенности в модификации опросника С. Баднера. Экспериментальная психология, 2014. № 1. C. $92-110$. 2006

8. Кувакин В.А., Ковалева В.П. Неизвестность. М.: Регулярная и хаотическая динамика,

9. Леонтьев Д.А. Экзистенциальная тревога и как с ней не бороться. Московский психотерапевтический журнал, 2003. № 2. С. 107-119.

10. Леонтьев Д.А. Личностное измерение человеческого развития. Вопросы психологии, 2013. № 3. С. $67-80$.

11. Леонтьев Д.А., Осин Е.Н. Печать экзистенциализма: эмпирические корреляты экзистенциального мировоззрения. Экзистенциальная традиция: философия, психология, психотерапия, 2007. № 1(10). С. 121-130.

12. Лобок А.М. Вероятностный мир. Екатеринбург: АМБ, 2001.

13. Мадди C. Смыслообразование в процессах принятия решения. Психологический журнал, 2005. № 26(6). C. 87-101.

14. Мэй Р. Смысл тревоги. М.: Класс, 2001.

() Barko Vadym I., Barko Vadym V., Kyriienko Liudmyla, 2019

DOI (Article): https://doi.org/10.36486/np.2019.2.22

Issue 2(4.4) 2019

http://naukaipravoohorona.com/ 
15. Осин Е.Н. Факторная структура русскоязычной версии шкалы общей толерантности к неопределенности Д. Маклейна. Психологическая диагностика, 2010. № 2. С. 65-86.

16. Пригожин И. Философия нестабильности. Вопросы философии, 1991. № 6. С. 46-52.

17. Собчик Л.Н. Психология индивидуальности. Теория и практика психодиагностики. СПб.: Речь, 2003. 624 с.

18. Соколова E.T. Клиническая психология утраты Я. М.: Смысл, 2015.

19. Талеб Н.Н. Антихрупкость: как извлечь выгоду из хаоса. М.: Колибри, 2014.

20. Франкл В. Человек в поисках смысла. М.: Прогресс, 1990.

21. Фромм Э. Душа человека. М.: Республика, 1992.

22. Эпштейн М.Н. Знак_пробела: о будущем гуманитарных наук. М.: НЛО, 2004. C. $422-438$.

23. Giorgi A. Whither Humanistic Psychology? The Humanistic Psychologist, 1992, 20(2-3).

24. Glimcher P.W. Indeterminacy in brain and behavior. Annual Review of Psychology, 2005, 56(1). C. $25-56$.

25. Proulx T., Heine S.J., Vohs K.D. When is the unfamiliar the uncanny? Measuring affirmation after exposure to absurdist literature, humor and art. Personality and Social Psychology Bulletin, 2010, 36(6). C. $817-829$.

\section{REFERENCES}

1. Asmolov A.G. (2001). Psikhologiya lichnosti: printsipy obshchepsikhologicheskogo analiza. "Psychology of personality: principles of general psychological analysis". M.: Smusl [in Russian].

2. Badyu A. (2013). Filosofiya i sobytiye. "Philosophy and event". M.: IOI [in Russian].

3. Vulf K . (2013). Vmesto predisloviya: neopredelennost' kak usloviye chelovecheskoy zhizni. V kn. Vulf K., Savchuk V. Neopredelennost' kak vyzov. Media. Antropologiya. Estetika. "Instead of a preface: uncertainty as a condition of human life". In the book. Wulf K., Savchuk V. Uncertainty as a challenge. Media Anthropology. Aesthetics. St. Petersburg: RCAA. P. 5-6 [in Russian].

4. Zinchenko V.P. (2007). Tolerantnost k neopredelennosti: novost ili psikhologicheskaya traditsiya? V kn. Bolotova A.K. Chelovek v situatsii neopredelennosti. "Tolerance to uncertainty: news or psychological tradition?” In the book. Bolotova A.K. Man in a situation of uncertainty. M.: TEIS. P. 9-33 [in Russian].

5. Kaneman D., Slovik P., Tverski A. (2005). Prinyatiye resheniy v neopredelennosti: Pravila i predubezhdeniya. "Decision making in uncertainty: Rules and prejudices". Kharkov: Humanitarian Center [in Russian].

6. Kormilova T.V. (2010). Printsip neopredelennosti v psikhologii: osnovaniya i problemy. Psikhologicheskiye issledovaniya. "The principle of uncertainty in psychology: the foundations and problems”. Psychological research. № 3(11), 11 p. [in Russian].

7. Kormilova T.V., Chumakova M.A. (2014). Shkaly tolerantnosti i intolerantnosti k neopredelennosti v modifikatsii oprosnika S. Badnera. Eksperimentalnaya psikhologiya. "Scales of tolerance and intolerance to uncertainty in the modification of the S. Badner questionnaire". Experimental Psychology. No. 1. P. $92-110$ p. [in Russian].

8. Kuvakin V.A., Kovaleva V.P. (2006). Neizvestnost. "The unknown". M.: Regular and chaotic dynamics [in Russian].

9. Leontyev D.A. (2003). Ekzistentsialnaya trevoga i kak s ney ne borotsya. "Existential anxiety and how not to deal with it". Moscow Psychotherapeutic Journal, 2003. No. 2. P. 107-119 [in Russian].

10. Leontyev D.A. (2013). Lichnostnoye izmereniye chelovecheskogo razvitiya. "The personal dimension of human development”. Questions of Psychology. No. 3. P. 67-80 [in Russian].

11. Leontyev D.A., Osin Ye.N. (2007). Pechat ekzistentsializma: empiricheskiye korrelyaty ekzistentsialnogo mirovozzreniya. Ekzistentsialnaya traditsiya: filosofiya, psikhologiya, psikhoterapiya. "Seal of existentialism: empirical correlates of an existential worldview". Existential Tradition: Philosophy, Psychology, Psychotherapy, 2007. No. 1(10). P. 121-130 [in Russian]. Russian].

12. Lobok A.M. (2001). Veroyatnostnyy mir. "The probabilistic world". Ekaterinburg: AMB [in

13. Maddi S. (2005). Smysloobrazovaniye v protsessakh prinyatiya resheniya. "Meaning in decision-making processes". Psychological journal. No. 26(6). P. 87-101 [in Russian].

14. Mey R. (2001). Smysl trevogi. "The meaning of anxiety". M.: Class [in Russian].

() Barko Vadym I., Barko Vadym V., Kyriienko Liudmyla, 2019

DOI (Article): https://doi.org/10.36486/np.2019.2.22 
15. Osin Ye.N. (2010). Faktornaya struktura russskoyazychnoy versii shkaly obshchey tolerantnosti k neopredelennosti D. Makleyna. "The factor structure of the Russian-language version of the scale of general tolerance to uncertainty D. MacLane”. Psychological Diagnostics, 2010. No. 2. P. 65-86 [in Russian].

16. Prigozhin I. (1991). Filosofiya nestabilnosti. "Philosophy of instability". Questions of Philosophy. No 6. P. 46-52 [in Russian].

17. Sobchik L.N. (2003). Psikhologiya individualnosti. "Psychology of personality". Theory and practice of psychodiagnostics. SPb.: Speech. 624 p. [in Russian].

18. Sokolova Ye.T. (2015). Klinicheskaya psikhologiya utraty Ya. "Clinical Psychology of the Loss of I". M.: Smusl [in Russian].

19. Taleb N.N. (2014). Antikhrupkost: kak izvlech vygodu iz khaosa. "Anti-fragility: how to capitalize on chaos". M.: Hummingbird [in Russian].

20. Frankl V. (1990). Chelovek v poiskakh smysla. "Man in search of meaning". M.: Progress [in Russian].

21. Fromm E. (1992). Dusha cheloveka. "The soul of man". M.: Republika [in Russian].

22. Epshteyn M.N. (2004). Znak_probela: o budushchem gumanitarnykh nauk. "Space_bar: The future of the humanities. M.: NLO [in Russian].

23. Giorgi A. (1992). Whither Humanistic Psychology? The Humanistic Psychologist, 20(23), P. 422-438 [in English].

24. Glimcher P.W. (2005). Indeterminacy in brain and behavior. Annual Review of Psychology, 56(1), P. 25-56 [in English].

25. Proulx T., Heine S.J., Vohs K.D. (2010). When is the unfamiliar the uncanny? Measuring affirmation after exposure to absurdist literature, humor and art. Personality and Social Psychology Bulletin, 36(6), P. 817-829 [in English].

UDC 159.922

Barko Vadym I.,

Doctor of Psychological Sciences, Professor, Chief Researcher, State Research Institute MIA Ukraine, Kyiv, Ukraine,

ORCID ID 0000-0003-4962-0975, Barko Vadym V.,

Candidate of Pedagogic Sciences, Senior Researcher, State Research Institute MIA Ukraine, Kyiv, Ukraine, ORCID ID 0000-0002-3836-2627, Kyriienko Liudmyla, Leading Researcher, State Research Institute MIA Ukraine, Kyiv, Ukraine, ORCID ID 0000-0001-9394-1288

\section{DEVELOPMENT OF A UKRAINIAN-SPEAKING QUESTIONNAIRE ON TOLERANCE TO UNCERTAINTY FOR USE BY THE NATIONAL POLICE OF UKRAINE}

The article is devoted to the question of Ukrainian-speaking adaptation of psychodiagnostic method "The questionnaire of tolerance to the uncertainty of S. Badner". The research was aimed at improving the system of professional

( $)$ Barko Vadym I., Barko Vadym V., Kyriienko Liudmyla, 2019

DOI (Article): https://doi.org/10.36486/np.2019.2.22 
psychological selection of personnel for the National Police of Ukraine. The current interest in the study of the level of individual tolerance to uncertainty is connected with research, indicates the practical significance of this construct in various fields of activity; many authors claim that tolerance to uncertainty is important for success in legal, medical, pedagogical and other professions. According to research findings, tolerance for uncertainty may correlate with intelligence, and it is also related to the factors of the "Big Five" questionnaire: positive with openness of experience and extraversion, negative - with neuroticism.

The article describes the theoretical basis and internal structure of the adaptation process, discloses the procedure and results of the research on the reliability and validity of the adapted Badner's questionnaire, the obtained average standard indicators for the general sample of police officers and defines new standardized test norms. According to the results of the statistical analysis, a decrease in tolerance to uncertainty among women has been identified, as well as an age-related decrease in this indicator in the police force. The conclusion is made that such quality of a person as tolerance to uncertainty will provide increase of efficiency of activity of policemen, will allow them to endure unforeseen situations better, to search for variable decisions of tasks in view, will increase stress resistance, will strengthen productive mechanisms of psychological protection of a person (rationalization, sublimation, displacement) and psychological readiness for actions in special and extreme conditions. The results of the study confirmed the diagnostic verification of the adapted questionnaire.

Keywords: tolerance to uncertainty, psychodiagnostic techniques, Ukrainian language adaptation, reliability, validity, average normative indices, standardized test norms.

Отримано 05.06.2019

(C) Barko Vadym I., Barko Vadym V., Kyriienko Liudmyla, 2019

DOI (Article): https://doi.org/10.36486/np.2019.2.22 


\title{
ТЕНДЕНЦІЇ ВДОСКОНАЛЕННЯ ТЕРМІНОЛОГІЧНОГО АПАРАТУ АДМІНІСТРАТИВНО-ПРОЦЕСУАЛЬНОЇ ТЕОРІї
}

\author{
(рецензія на монографію Тернущака М.M. \\ "Правова природа адміністративного процесу \\ в контексті публічного адміністрування”)
}

У монографічному дослідженні кандидата юридичних наук М.М. Тернущака “Правова природа адміністративного процесу в контексті публічного адміністрування" за загальною редакцією доктора юридичних наук, професора Т.О. Проценка піднімається питання зумовленості удосконалення термінологічного апарату теорії наук адміністративного права та процесу в сучасних умовах трансформації правової науки. Відповідне твердження зумовлене низкою чинників та передумов, які, своєю чергою, на теоретико-правовому рівні надають змогу поіншому розкрити значення та зміст базових категоріально-понятійних конструкцій. Яскравим прикладом цього, на думку автора, виступає необхідність уточнення предмета правового регулювання наук адміністративного права та процесу, що в умовах людиноцентриської течії в адміністративістиці нагально потребує нових науково-термінологічних напрацювань.

Загалом теорія адміністративного процесу як складова адміністративноправової науки останнім часом динамічно розвивається, що яскраво ілюстровано у позиціях наукових адміністративних шкіл України щодо призначення, місця та ролі адміністративного права у площині реалізації конституційних прав. Управлінська роль адміністративного права поступово нівелюється адмініструючою роллю, що з практичного боку означає вироблення та застосування нових сервісних методик у діяльності публічної адміністрації, таких як: надання адміністративних послуг ЦНАПами, впровадження електронних сервісів (е-послуг) у межах електронного врядування, делегування повноважень виконавчої влади місцевому самоврядуванню (реєстраційні процедури).

3 іншого боку, передумовами трансформації адміністративно-правової теорії виступають зовнішньополітичні процеси та виконання міжнародних зобов'язань Україною, як-от підписання Угоди про асоціацію з СС та подальша реалізація нормативних заходів адміністративної реформи, що передбачає суттєве оновлення адміністративного законодавства.

Усі викладені вище аспекти (передумови) удосконалення термінологічного апарату адміністративно-правової теорії було враховано в межах здійсненого монографічного дослідження, опираючись на обрану методологію, структурність і його послідовність.

3 огляду на зазначене, наукова праця, підготовлена М.M. Тернущаком на тему “Правова природа адміністративного процесу в контексті публічного адміністрування”, є актуальною з погляду науки адміністративного права та процесу. Слід наголосити, що монографія становить комплексне дослідження, цілісне за

DOI (Article): https://doi.org/10.36486/np.2019.2.23

(c) Bortnyk Nadiia, 2019 
формою та завершене за змістом, спрямоване на розвиток сучасної правової доктрини.

Враховуючи аналіз предмета монографічного дослідження, що складає правову природу адміністративного процесу в контексті парадигми новітньої категорії “публічного адміністрування”, цілком логічно виглядає необхідність трактування відповідної категорії, а також визначення системоутворюючої складової публічного інтересу та розмежування публічного адміністрування з управлінням. Необхідно зазначити, що публічне адміністрування є сучасною категорією, яка, по суті, замінила державне управління в науково-теоретичному обігу, демонструючи зміну пріоритету функціонування самої державної системи у русі від адміністративнокомандної до сервісної. Відтак цілком поділяємо позицію автора щодо запропонованої ним методології трактування та подальшого висвітлення у дослідженні категорій “публічне адміністрування”, “публічне управління”, зокрема:

по-перше, категорію “публічне адміністрування” автор розглядає через призму вузького та широкого значень. У вузькому - як діяльність органів публічної адміністрації (сукупності державних виконавчих та муніципальних органів) щодо задоволення публічних потреб (інтересу) фізичних та юридичних осіб. У широкому значенні - як діяльність публічної адміністрації щодо реалізації публічного інтересу, спрямовану на забезпечення конституційних прав, свобод та інтересів особи у публічно-правових відносинах. При цьому повністю підтримуємо авторську ідею, згідно з якою недоцільно обмежуватись традиційною інтерпретацією публічної адміністрації як сукупністю органів виконавчої та муніципальної влади, а наголосити саме на спрямуванні діяльності відповідних органів, тобто сервісній складовій. Отже, категорія “публічна адміністрація" складає систему державних органів виконавчої влади, органів місцевого самоврядування, які згідно з законодавством України реалізують функції публічного адміністрування в адміністративноправових відносинах, у тому числі відносинах із надання адміністративних послуг щодо реалізації публічного інтересу;

по-друге, категорію “публічне управління”, безумовно, визначено як похідну публічного адміністрування, оскільки вона відображає специфіку проходження публічної служби. Тому публічне управлінням, передусім, стосується внутрішньоорганізаційної діяльності органів публічної адміністрації та розкриває процеси, пов'язані з:

- вступом, проходженням та припиненням публічної служби;

- виконанням завдань та функцій органу, де особа працює, визначених штатним розписом посадових повноважень, а також завдань, доручень, вказівок безпосереднього та вищого керівництва;

- організаційно-правовим забезпеченням функціонування публічного органу (нормативного, кадрового, фінансового, матеріально-технічного).

Стосовно інтерпретації поняття “адміністративний процес", автор запропонував його поділ на конфліктний, судовий та сервісний, зважаючи на традиційні концепції (судову, деліктну, управлінську) у трактуванні відповідного виду юридичного процесу, а також виходячи зі специфіки нормативного регулювання. Проте, на наше переконання, вагому роль у виокремленні окремого виду адміністративного процесу в адміністративно-процесуальній теорії, зокрема сервісного,

DOI (Article): https://doi.org/10.36486/np.2019.2.23

(c) Bortnyk Nadiia, 2019 
відіграла категорія “публічного адміністрування”, яка дозволила автору на основі управлінської концепції модифікувати одне з класичних трактувань (управлінського адміністративного процесу) на сервісний. У цьому напрямі автором запропоновано удосконалити термінологічний апарат адміністративно-процесуальної теорії шляхом уведення в науковий обіг інтерпретації адміністративного процесу, розмежовуючи його на конфліктний, судовий та сервісний. Конфліктний адміністративний процес полягає у розв’язанні публічно-правових спорів конфліктного характеру (адміністративно-судових справ, справ про адміністративні правопорушення та справ, що виникають з приводу розгляду скарг громадян) у судовому та адміністративному порядках. Відтак: “Конфліктний адміністративний процес - це діяльність суб'єктів публічної адміністрації (адміністративних органів) та адміністративних судів, у тому числі судів загальної юрисдикції, щодо вирішення публічноправових спорів, деліктних справ та розгляду скарг”; “Судовий адміністративний процес - це діяльність адміністративних судових установ з розгляду та вирішення публічно-правових спорів та деліктних (адміністративних) справ у порядках, визначених КАСУ та КУпАП”; “Сервісний адміністративний процес - це діяльність органів публічної адміністрації, яка полягає у вирішенні індивідуально-конкретних справ фізичних та юридичних осіб за їх зверненнями щодо надання адміністративних послуг”.

Крім того, в межах дослідження адміністративно-процесуальної теорії автор звернувся до актуального питання співвідношення понять “адміністративна процедура”, “адміністративне провадження”. Зауважимо, що при вирішенні відповідного питання здійснено аналіз достатнього масиву наукових напрацювань та чинного адміністративного законодавства, в результаті чого розроблено та подано низку пропозицій стосовно удосконалення термінологічної частини законопроекту “Про адміністративну процедуру”, передусім, авторського бачення та співвідношення категорій “адміністративна процедура”, “адміністративне провадження”. Адміністративна процедура - порядок послідовного виконання процесуальних дій в межах регламентованої стадійності та етапізації щодо розгляду адміністративної справи, який регулюється одним або декількома законодавчими чи підзаконними актами; Адміністративне провадження - нормативно-встановлений порядок виконання процесуальних дій у межах індивідуального вирішення адміністративної справи.

Також надано авторські визначення процедур реалізації проваджень адміністративного процесу, а саме: судового, деліктного, адміністративного оскарження. Процедура реалізації адміністративно-судового провадження - це регламентований КАСУ порядок виконання процесуальних стадій щодо розгляду публічно-правового спору відносно оскарження рішень, дій чи бездіяльності суб'єктів владних повноважень або оскарження суб'єктом владних повноважень реалізації окремих конституційних прав у такій послідовності: звернення до адміністративного суду, відкриття адміністративної справи (провадження), підготовка адміністративної справи до розгляду, розгляд адміністративної справи, винесення (постановлення) рішення по суті адміністративної справи; Процедура реалізації провадження 3 розгляду скарг (адміністративного оскарження) - це регламентований Законом “Про звернення громадян”, відомчими підзаконними актами порядок виконання процесуальних стадій щодо розгляду скарг на рішення органів (посадових осіб)

DOI (Article): https://doi.org/10.36486/np.2019.2.23

(C) Bortnyk Nadiia, 2019 Issue 2(44) 2019 http://naukaipravoohorona.com/ 
публічної адміністрації, які подаються у порядку підлеглості до вищого органу (посадової особи, комісії) за такою послідовністю: подання скарги на рішення (адміністративний акт) публічної адміністрації, відкриття провадження адміністративного оскарження, розгляд скарги щодо предмета оскарження, винесення рішення по суті розгляду скарги; Процедура реалізації провадження з надання адміністративних послуг - це нормативно-регламентований порядок (регулюється відомчими документами (технологічними картками)) послідовного виконання процесуальних дій (етапів) посадовими особами (адміністраторами, (консультантами, модераторами)) ЦНАП щодо консультування суб'єктів звернення, реєстрації звернення, направлення звернення за належністю (у структурні підрозділи) для опрацювання та накладення резолюції на кожному з етапів та прийняття остаточного рішення щодо задоволення чи відмови у зверненні стосовно видачі індивідуального акта дозвільного, посвідчувального, реєстраційного, ліцензійного, атестаційного типів.

У результаті проведеного монографічного дослідження, М.М. Тернущаком запропоновано актуальні пропозиції з удосконалення термінологічного апарату адміністративно-процесуальної теорії, що в умовах приведення адміністративного законодавства до стандартів СС та трансформації адміністративно-правової науки робить вагомий внесок у розвиток вітчизняної юридичної науки загалом, а також буде корисним для використання у науково-дослідницьких цілях, практичній діяльності, навчально-методичному забезпеченні викладання дисциплін адміністративно-правового циклу.

Отже, монографія “Правова природа адміністративного процесу в контексті публічного адміністрування”, підготовлена М.М. Тернущаком, цілком справедливо є серйозною, вдумливою науковою працею з притаманними їй елементами академізму. Особистий внесок автора у вітчизняну науку адміністративного права та процесу цілком очевидний і заслуговує високої оцінки.

\section{Завідувач кафедри адміністративного та інформаційного права Навчально-наукового інституту права та психології Національного університету “Львівська політехніка", доктор юридичних наук, професор}

Надія Петрівна Бортник 
DOI (Issue): https://doi.org/10.36486/np.2019.2

\title{
НАУКА І ПРАВООХОРОНА
}

НАУКОВИЙ ЖУРНАЛ

\section{NAUKA I PRAVOOKHORONA}

SCIENTIFIC JOURNAL

\author{
Випусковий редактор \\ Лелет С.М. \\ Редакційна група: \\ Гира Я.M. \\ (переклад на англійську мову), \\ Кожухар O.B., \\ Якубчик T.B. \\ Комп'ютерна верстка: \\ мухіна T.M. \\ Issuing Editor \\ Lelet S.M. \\ Editorial Group \\ Hyra Ya.M. \\ (English \\ interpreter), \\ Kozhukhar O.V., \\ Yakubchyk T.V. \\ Page Makeup \\ Mukhina T.M.
}


Підписано до друку 19.06.2019.

Формат 60x80 1/s. Гарнітура Petersburg. Друк офсетний.

Папір офсетний. Ум.-друк. арк. 10,1.

Наклад 100.

Видавець ФОП Горбенко Ю.В.

м. Харків, вул. Ахсарова, 3, корп. В, кв. 168.

Дата та номер запису в ЄДР

0108.2017 № 24800000000198912. 